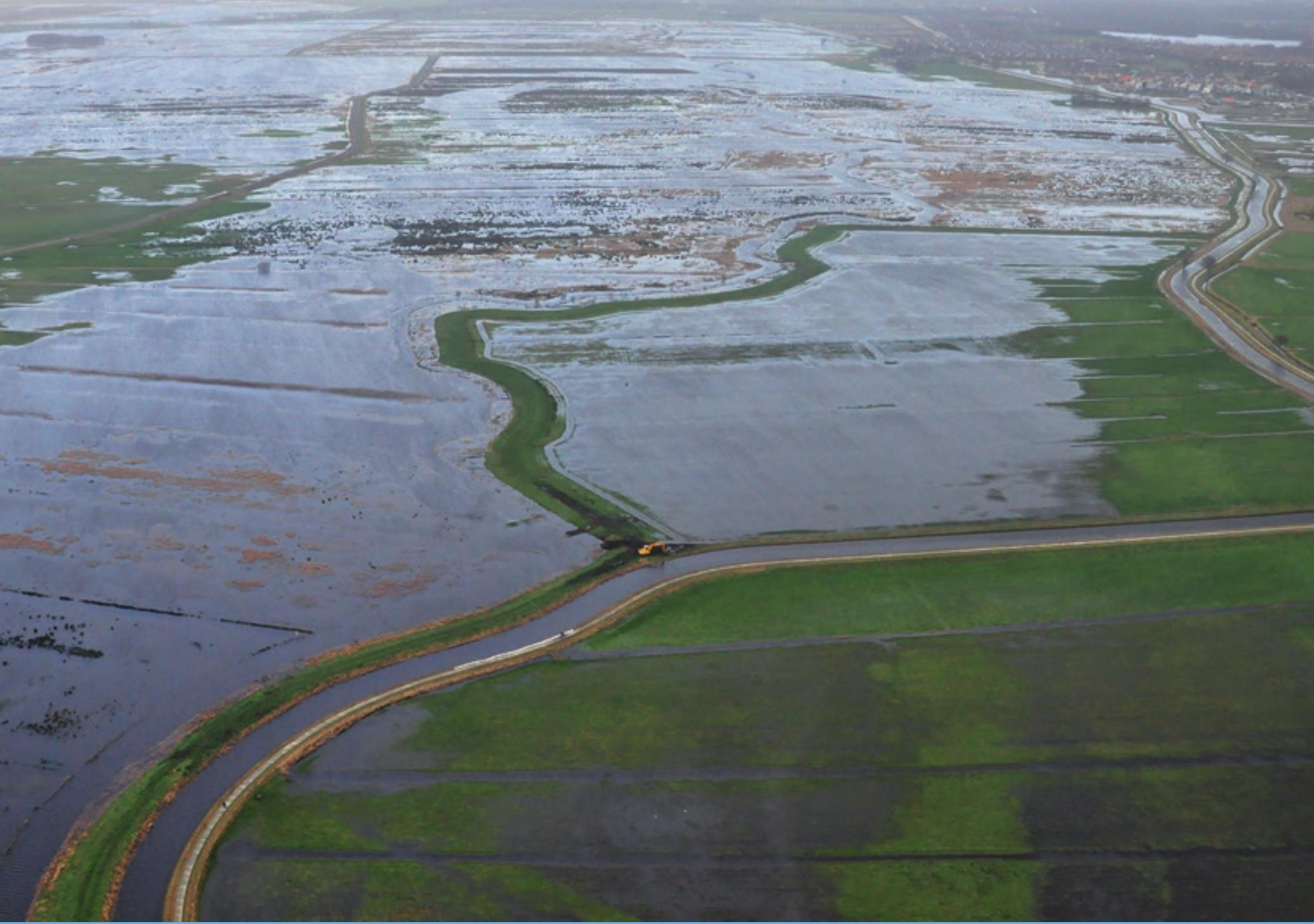

\title{
Nederland inrichten met het principe van natuurlijke klimaatbuffers
}

De leerervaringen

J.A. Veraart, J. Klostermann, M. Sterk, R. Janmaat. E. Oosterwegel, M. van Buuren, T. van Hattum

WAGENINGEN UNIVERSITY \& RESEARCH natuurlijke klimaatbuffers

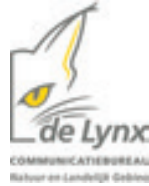





\section{Nederland inrichten met het principe van natuurlijke klimaatbuffers}

De leerervaringen

J.A. Veraart, J. Klostermann, M. Sterk, R. Janmaat. E. Oosterwegel, M. van Buuren, T. van Hattum

Dit onderzoek is uitgevoerd door Wageningen Environmental Research, Wageningen University en Communicatiebureau de Lynx in opdracht van de Coalitie Natuurlijke Klimaatbuffers (penvoerder: Staatsbosbeheer).

Wageningen Environmental Research

Wageningen, december 2019

Gereviewd door:

Eric Arets (Wageningen Environmental Research)

Akkoord voor publicatie:

Derk Rademaker (Wageningen Environmental Research)

Rapport 2975

ISSN 1566-7197 
Veraart, J.A., Klostermann, J.E.M., Sterk, M., Janmaat, R., Oosterwegel, E., van Buuren, M., van Hattum, T., 2019. Nederland inrichten met het principe van natuurlijke klimaatbuffers; De leerervaringen. Wageningen, Wageningen Environmental Research, Rapport 2975. 102 blz.; 11 fig.; 27 tab.; 173 ref.

Het klimaat verandert en Nederland krijgt steeds vaker te maken met periodes van droogte, hitte en extreme neerslag. Dat is nu al actueel. Natuurlijke klimaatbuffers zijn gebieden waar natuurlijke processen de ruimte krijgen, op deze wijze is aanpassing aan klimaatverandering voor Nederland mogelijk. Het concept 'natuurlijke klimaatbuffer' heeft een groot potentieel, maar wordt nog niet altijd meegenomen in planvorming. In deze evaluatie is uitgezocht wat er nodig is om de klimaatbufferaanpak als standaard optie in te bedden in ruimtelijk beleid en in water- en natuurbeheer.

The Netherlands is increasingly confronted with periods of drought, heat and extreme rainfall due to climate change. Nature based solutions are areas where natural processes are the basis for adaptation to climate change. Nature based solutions have great potential, but are not yet always used in spatial planning and water management. This evaluation investigated what is needed to embed nature based solutions as a standard option in spatial policy and in water and nature management.

Trefwoorden: klimaatverandering, meekoppelkansen, klimaatadaptatie, evaluatie

Dit rapport is gratis te downloaden van https://doi.org/10.18174/508730 of op www.wur.nl/environmental-research (ga naar 'Wageningen Environmental Research' in de grijze balk onderaan). Wageningen Environmental Research verstrekt geen gedrukte exemplaren van rapporten.

2019 Wageningen Environmental Research (instituut binnen de rechtspersoon Stichting Wageningen Research), Postbus 47, 6700 AA Wageningen, T 0317480700 , www.wur.nl/environmental-research. Wageningen Environmental Research is onderdeel van Wageningen University \& Research.

- Overname, verveelvoudiging of openbaarmaking van deze uitgave is toegestaan mits met duidelijke bronvermelding.

- Overname, verveelvoudiging of openbaarmaking is niet toegestaan voor commerciële doeleinden en/of geldelijk gewin.

- Overname, verveelvoudiging of openbaarmaking is niet toegestaan voor die gedeelten van deze uitgave waarvan duidelijk is dat de auteursrechten liggen bij derden en/of zijn voorbehouden.

Wageningen Environmental Research aanvaardt geen aansprakelijkheid voor eventuele schade voortvloeiend uit het gebruik van de resultaten van dit onderzoek of de toepassing van de adviezen.

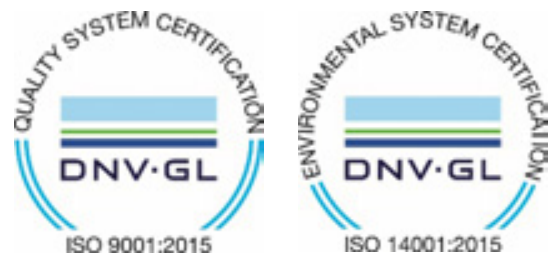

Wageningen Environmental Research werkt sinds 2003 met een ISO 9001 gecertificeerd kwaliteitsmanagementsysteem. In 2006 heeft Wageningen Environmental Research een milieuzorgsysteem geïmplementeerd, gecertificeerd volgens de norm ISO 14001.

Wageningen Environmental Research geeft via ISO 26000 invulling aan haar maatschappelijke verantwoordelijkheid.

Wageningen Environmental Research Rapport 2975 | ISSN 1566-7197

Foto omslag: De Onlanden van Boven (Natuurmonumenten) 


\section{Inhoud}

Verantwoording $\quad 5$

$\begin{array}{ll}\text { Woord vooraf } & 7\end{array}$

$\begin{array}{ll}\text { Abstract } & 9\end{array}$

$\begin{array}{ll}\text { Samenvatting voor beleid } & 11\end{array}$

1

$\begin{array}{lr}\text { Introductie } & 19\end{array}$

1.1 Achtergrond $\quad 19$

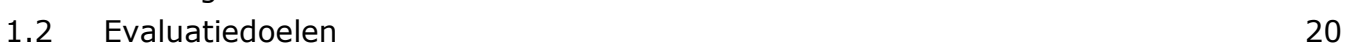

$\begin{array}{lll}1.3 & \text { Leeswijzer } & 21\end{array}$

2

$\begin{array}{ll}\text { Evaluatiemethode } & 22\end{array}$

$\begin{array}{lll}2.1 & \text { Introductie } & 22\end{array}$

2.2 Deskstudie $\quad 23$

$\begin{array}{lll}2.3 & \text { De omgevingsscan } & 25\end{array}$

2.3.1 Interviews $\quad 25$

$\begin{array}{ll}2.3 .2 \text { Bijeenkomsten } & 26\end{array}$

2.4 Verdieping met geselecteerde klimaatbuffers 26

$3 \quad$ CNK-programma in vogelvlucht $\quad 28$

3.1 Periode 2008-2014: pilotfase 28

3.2 Periode 2015-2022: mainstream maken $\quad 29$

$\begin{array}{lll}3.3 & \text { Belangrijkste conclusies uit voorgaande evaluaties } & 31\end{array}$

$4 \quad$ Verdieping met geselecteerde klimaatbuffers $\quad 34$

$\begin{array}{lll}4.1 & \text { Introductie } & 34\end{array}$

$\begin{array}{lll}4.2 & \text { Onlanden } & 34\end{array}$

4.3 Ooijen-Wansum 36

$\begin{array}{lll}4.4 & \text { Rivierklimaatpark IJsselpoort } & 37\end{array}$

$\begin{array}{lll}4.5 & \text { IJsselmonde } & 39\end{array}$

$\begin{array}{lll}4.6 & \text { Ilperveld } & 40\end{array}$

$\begin{array}{lll}4.7 & \text { Anserveld/Leisloot } & 41\end{array}$

$\begin{array}{lll}4.8 & \text { Oesterdam } & 44\end{array}$

$5 \quad$ Bijdragen aan klimaatbeleid, natuurdoelen en economische ontwikkeling

5.1 Klimaatbuffertype Groenblauwe Ruimte $\quad 47$

$\begin{array}{ll}5.1 .1 & \text { Inleiding }\end{array}$

5.1.2 Bijdragen aan klimaatbeleid, natuurdoelen en economie 48

5.2 Koolstof-sink $\quad 51$

5.2.1 Inleiding 51

5.2.2 Bijdragen aan doelen klimaat, natuur en economie 53

5.3 Natuurlijke Spons $\quad 58$

5.3.1 Inleiding 58

5.3.2 Bijdragen aan doelen klimaat, natuur en economie $\quad 59$

5.4 Levende Kust en Biobouwers $\quad 62$

5.4.1 Inleiding $\quad 62$

5.4.2 Bijdragen aan doelen klimaat, natuur en economie $\quad 64$ 
$5.5 \quad$ Groene Airco $\quad 66$

5.5.1 Inleiding 66

5.5.2 Bijdragen aan doelen klimaat, natuur en economie 66

$\begin{array}{lll}5.6 & \text { Conclusies } & 67\end{array}$

6

$\begin{array}{ll}\text { Hoe kijken anderen naar klimaatbuffers? } & \mathbf{7 1}\end{array}$

$\begin{array}{lll}6.1 & \text { Introductie } & 71\end{array}$

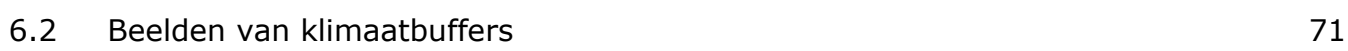

$\begin{array}{lll}6.3 & \text { Betrokkenheid bij klimaatbuffers } & 72\end{array}$

$\begin{array}{lll}6.4 & \text { Doelen van klimaatbuffers } & 73\end{array}$

$\begin{array}{lll}6.5 & \text { Kansen voor klimaatbuffers } & 74\end{array}$

$\begin{array}{lll}6.6 & \text { Belemmeringen (faalfactoren) } & 74\end{array}$

$\begin{array}{lll}7.1 & \text { Introductie } & 77\end{array}$

$\begin{array}{lll}7.2 & \text { Resultaten } & 77\end{array}$

$\begin{array}{lll}8.1 & \text { Introductie } & 79\end{array}$

8.2 Koppelkansen met waterbeheer in het rivierengebied $\quad 81$

8.2.1 Integraal Rivier Management en Programmatische Aanpak Grote Wateren 81

8.2.2 Deltaprogramma $\quad 82$

8.2.3 Klimaatakkoord 83

8.3 Koppelkansen met waterbeheer in Hoog-Nederland $\quad 83$

$\begin{array}{ll}\text { 8.3.1 Deltaprogramma } & 83\end{array}$

$\begin{array}{ll}\text { 8.3.2 Klimaatakkoord } & 83\end{array}$

$\begin{array}{ll}\text { 8.3.3 Drinkwatersector } & 84\end{array}$

8.3.4 Landbouw en voedselproductie $\quad 84$

8.4 Koppelkansen met klimaatbeleid $\quad 85$

8.4.1 Koppelkansen met Klimaatakkoord $\quad 85$

8.4.2 Koppelkansen Deltaprogramma en Klimaatakkoord (kwadraat) 86

8.5 Koppelkansen met gebiedsontwikkeling in stedelijk gebied 86

8.5.1 Deltaprogramma Ruimtelijke adaptatie 86

8.5.2 Nationale Omgevingsvisie (NOVI) 87

$\begin{array}{lll}8.6 & \text { Koppelkansen langs de kust } & 87\end{array}$

8.6.1 Deltaprogramma (waterveiligheid) 87

8.6.2 Koppelkansen met de koolstofcertificaten en PAGW 87

$9 \quad$ Aanbevelingen voor inbedding in beleid $\quad 89$

$\begin{array}{lll}9.1 & \text { Inleiding } & 89\end{array}$

9.2 Het vliegwiel gebiedsontwikkeling $\quad 90$

9.3 Nationale klimaatopgaven als vliegwiel $\quad 91$

9.4 Samenwerken met de private sector $\quad 91$

9.5 Monitoring en evaluatie met lerend implementeren $\quad 92$

$\begin{array}{ll}\text { Literatuur } & 93\end{array}$ 


\section{Verantwoording}

Rapport: 2975

Projectnummer: 5200044871

Wageningen Environmental Research (WENR) hecht grote waarde aan de kwaliteit van onze eindproducten. Een review van de rapporten op wetenschappelijke kwaliteit door een referent maakt standaard onderdeel uit van ons kwaliteitsbeleid.

Akkoord Referent die het heeft beoordeeld,

functie: Onderzoeker Bosecosystemen

naam: $\quad$ Eric Arets

datum: juli 2019

Akkoord teamleider voor de inhoud,

naam: Derk Rademaker

datum: november 2019 


\section{Woord vooraf}

De Coalitie Natuurlijke Klimaatbuffers heeft de ambitie om Nederland zoveel mogelijk in te richten met natuurlijke oplossingen. Dat is een grote klus en die klus startte in 2008. De vraag werd aan ons gesteld of die ambitie realiseerbaar is voor 2022. We hebben daartoe met allerlei mensen gesproken, van een Rijksambtenaar in Den Haag tot de terreinbeheerder in de Onlanden. Het was een leerzame reis. Al onze ervaringen, maar ook van al die mensen met wie gesproken is, zijn in dit rapport opgeschreven. Dat was geen makkelijke, maar wel een leerzame taak. Er is sinds 2008 door de Coalitie Natuurlijke Klimaatbuffers veel bereikt. Het programma is de pilotfase in onze ogen wel voorbij en er zijn steeds meer partijen in Nederland geïnspireerd geraakt door het concept. Dat was mooi om te ontdekken. Er is ook nog veel werk aan de winkel, we hopen dat dit snel genoeg gaat om Nederland klimaatbestendig te krijgen met natuurlijke oplossingen. Langs deze weg willen wij ook de begeleiders van deze evaluatie bedanken, in het bijzonder Boukelien Bos, Paul Vertegaal en Anne Kruft.

November 2019

Jeroen Veraart, Judith Klostermann, Marjolein Sterk, Rob Janmaat, Eva Oosterwegel, Michael van Buuren, Tim van Hattum 


\section{Abstract}

Het klimaat verandert en Nederland krijgt steeds vaker te maken met periodes van droogte, hitte en extreme neerslag. Dat is nu al actueel. Natuurlijke klimaatbuffers zijn gebieden waar natuurlijke processen de ruimte krijgen, op deze wijze is aanpassing aan klimaatverandering voor Nederland mogelijk. Het concept 'natuurlijke klimaatbuffer' heeft een groot potentieel, maar wordt nog niet altijd meegenomen in planvorming. In deze evaluatie is uitgezocht wat er nodig is om de klimaatbufferaanpak als standaard optie in te bedden in ruimtelijk beleid en in water- en natuurbeheer. De resultaten illustreren dat natuurlijke oplossingen bijdragen aan klimaatadaptatie en leiden tot een verbetering van de waterveiligheid en watervoorziening. De twintig geëvalueerde natuurlijke klimaatbuffers laten vrijwel altijd herstel en ontwikkeling van flora en fauna zien op projectniveau, op groter systeemniveau is het nog te vroeg om effecten te zien. Bij de start in 2008 was klimaatmitigatie geen doel. Er zijn echter wel projecten in Noord-Nederland (De Onlanden, Hunze) uitgevoerd met veel potenties voor klimaatmitigatie, en na 2012 zijn er ook initiatieven opgestart in West-Nederland. Er zijn steeds meer voorbeelden in het waterbeheer waarbij natuurlijke oplossingen ook daadwerkelijk kosten besparen. Deze evaluatie laat zien dat het principe van natuurlijke klimaatbuffers inmiddels de pilotfase wel voorbij is. Het inbedden komt dus langzaam meer zeker op stoom; er is significante vooruitgang geboekt sinds de voorgaande evaluaties uit 2014. De missie van de CNK is nog niet op alle punten gehaald maar is wel realiseerbaar. 


\section{Samenvatting voor beleid}

\section{Probleemstelling}

Het klimaat verandert en Nederland krijgt steeds vaker te maken met periodes van droogte, hitte en extreme neerslag. Dat is nu al actueel. Om de gevolgen te beperken moeten we klimaatverandering tegengaan en ons aanpassen. Natuurlijke klimaatbuffers zijn gebieden waar natuurlijke processen de ruimte krijgen. Ze vervullen een rol bij het vasthouden en opvangen van water, het voorkomen van watertekorten, het temperen van hitte en het verminderen van kooldioxide in de atmosfeer. Zo groeien ze mee met klimaatverandering en verbeteren ze de leefbaarheid van Nederland. Er zijn verschillende typen te onderscheiden die zich richten op natuurlijke oplossingen voor waterberging (type Groenblauwe Ruimte), water vasthouden (Natuurlijke Spons), waterveiligheid langs de kust (type Levende Kust, type Biobouwers), verkoeling in de stad (Groene Airco) en het vastleggen van broeikasgassen (Koolstof-sink).

De Coalitie Natuurlijke Klimaatbuffers (CNK) bestaat uit acht samenwerkende natuurorganisaties ${ }^{1}$. Bij elkaar hebben deze organisaties sinds 2008 ruim zeventig natuurlijke klimaatbuffers opgestart, waarvan twintig binnen het door het Rijk gefinancierde programma Natuurlijke Klimaatbuffers (20082014). Deze klimaatbuffers liggen verspreid over heel Nederland en zijn gerealiseerd in samenwerking met het Rijk, waterschappen en andere overheden, eigen middelen en financiering van bijvoorbeeld de Postcode Loterij. In eerdere evaluaties is geconcludeerd dat het concept 'natuurlijke klimaatbuffer' een groot potentieel heeft voor bredere toepassing in verschillende beleidsdomeinen en tot kostenbesparing kan leiden ten opzichte van traditionele oplossingen. Desondanks nemen Rijk, provincies, gemeenten en waterschappen natuurlijke oplossingen nog niet altijd automatisch mee bij beslissingen over het aanpakken van klimaatopgaven. In het kader van het programma LIFE IP Deltanatuur zet de CNK zich in om de klimaatbuffer-aanpak als standaard optie in te bedden in ruimtelijk beleid en in water- en natuurbeheer.

\section{Doelen van de evaluatie}

De evaluatie heeft vier doelen:

- een geactualiseerd overzicht krijgen van de bijdragen van natuurlijke klimaatbuffers aan klimaatadaptatie, klimaatmitigatie, natuurdoelen en economie (kosten, baten, sociaaleconomische aspecten);

- lessen trekken uit succes- en faalfactoren bij het opstarten en uitvoeren van klimaatbuffers;

- benoemen van (mee)koppelkansen in beleid;

- advies geven over het inbedden van de klimaatbuffer-aanpak in waterbeheer en ruimtelijke ordening.

\section{Aanpak}

Er is een omgevingsscan (interviews, workshop) uitgevoerd om te verkennen welke ideeën beleidsmakers en andere stakeholders hebben over het inbedden van het concept in waterbeheer en ruimtelijk beleid. Tijdens de omgevingsscan is ook in beeld gebracht welke knelpunten ervaren worden. Daarna zijn voor zeven geselecteerde klimaatbuffer-projecten bijdragen, koppelkansen, succes- en faalfactoren in beeld gebracht door interviews met projectleiders. Met een deskstudie zijn de ervaringen van projectleiders en stakeholders, waar mogelijk, geverifieerd in de literatuur en aangevuld met ervaringen uit klimaatbufferprojecten waarmee geen interview is gedaan.

\section{Bijdragen van natuurlijke klimaatbuffers aan klimaatadaptatie}

De Coalitie Natuurlijke Klimaatbuffers onderscheidt zes typen klimaatbuffers. Eén daarvan, 'Koolstofsink' is vooral gericht op het reduceren van broeikasgasemissies door natte natuur. De vier andere zijn gericht op klimaatadaptatie door inzet van natuurlijke processen: Groenblauwe Ruimte, Natuurlijke Spons, Levende Kust, Biobouwers en Groene Airco.

${ }^{1}$ De Coalitie Natuurlijke Klimaatbuffers bestaat uit ARK Natuurontwikkeling, LandschappenNL, Natuur- en Milieufederaties, Natuurmonumenten, Staatsbosbeheer, Vogelbescherming Nederland, Waddenvereniging en Wereld Natuur Fonds. 
De resultaten illustreren dat natuurlijke oplossingen bijdragen aan klimaatadaptatie en leiden tot een verbetering van de waterveiligheid en watervoorziening. Natuurlijke vooroevers bij dijken, kwelderherstel, zandsuppleties, piekwaterberging rondom steden en in de uiterwaarden van rivieren bewijzen zich steeds meer als succesvolle klimaatadaptatie-strategieën en daarmee als volwaardig alternatief voor de traditionele aanpak ${ }^{2}$.

Waterberging rondom steden en in rivieruiterwaarden in combinatie met natuurontwikkeling is een succesverhaal. Naast de beschouwde klimaatbuffer-projecten zijn er nog veel meer van dit soort combinaties gerealiseerd in de afgelopen 10 jaar. In een aantal projecten is evaluatie van de effecten pas goed mogelijk na een extreem hoge afvoer of neerslaggebeurtenis.

Het is niet goed te beoordelen of gerealiseerde waterconservering in de individuele projecten ook leidt tot het verbeteren van het watervasthoudend vermogen en klimaatbestendigheid op stroomgebiedsniveau. De statistieken (PBL) van het antiverdrogingsbeleid laten nog steeds een toenemende verdroging van natte natuur zien, ondanks de realisatie van natuurlijke klimaatbuffers en overige maatregelen. Op basis van de beschikbare informatie was het niet mogelijk om uitspraken te doen of er verschillen zijn tussen natuurgebieden met en zonder hydrologische herstelmaatregelen. Daarnaast kan dit ook komen door een toenemende economische watervraag.

Natuurlijke principes in waterveiligheid worden steeds meer toegepast. De uitgevoerde natuurlijke klimaatbuffers die werken met sediment, vooroevers en kwelders (Levende Kust) zijn een flexibele klimaatadaptatie-strategie die mee kan groeien met de scenario's voor zeespiegelstijging van het KNMI tot 2050. Wat versnelde zeespiegelstijging na 2050 betekent is een onderzoeksvraag. De toepassing van biobouwers (schelpdierriffen, zeegras) zijn vaak nog in de experimentele fase waardoor opschaling nog niet aan de orde is.

Vooralsnog zijn er nog nauwelijks natuurlijke klimaatbuffers van het type 'Groene Airco'. Maatschappelijke partners van de CNK werken al wel met dit principe, en er komt steeds meer wetenschappelijk bewijs die het verkoelend effect van groen in de stad aantoont. Het verkoelend effect kan wellicht ook gezocht worden in natuurgebieden langs de randen van de stad, een koele uitloopgelegenheid.

Het kwantificeren van de effecten van de klimaatbuffer-projecten was niet eenvoudig. Het was bij aanvang van het CNK-programma geen kerntaak. Gezien de diversiteit en complexiteit van de projecten is een effectieve evaluatie van klimaatbuffer-projecten alleen mogelijk met een heldere omschrijving van het doel en hypotheses. Dat ontbrak soms bij de eerste klimaatbuffers. Met de toename van het aantal klimaatbuffers, is de aandacht gegroeid voor monitoring, vooral wanneer Rijkswaterstaat, waterschappen en stichting EcoShape een leidende rol bij de klimaatbuffer hebben (denk onder andere aan Zachte Zandmotor IJsselmeerkust, Oesterdam, Leuvenumse beek, Punt van Voorne).

\section{Bijdragen van natuurlijke klimaatbuffers aan klimaatmitigatie}

Bij de start in 2008 was klimaatmitigatie geen doel. Er zijn echter wel projecten in Noord-Nederland (De Onlanden, Hunze) uitgevoerd met veel potenties voor klimaatmitigatie, en na 2012 zijn er ook initiatieven opgestart in West-Nederland. Landgebonden broeikasgasemissies verklaren 3-4\% van de jaarlijks gerapporteerde emissies. Met natte natuur is een groot deel van de geambieerde emissiereductie voor landgebruik uit het Klimaatakkoord realiseerbaar (0,4-0,8 Mton jr $\left.\mathrm{j}^{-1}\right)$. Herstel en ontwikkeling van kwelders kan daar via 'blue carbon' nog 0,1 Mton jr-1 aan bijdragen. Met uitbreiding van vernatte bufferzones rond natuurgebieden en door functiewijziging op veengrond is wellicht nog meer emissiereductie realiseerbaar. Daar is echter maatschappelijk draagvlak voor nodig. Wanneer ontwikkeling van moerasnatuur op veen gecombineerd wordt met waterberging rondom steden versterken klimaat- en waterbeleid elkaar.

\footnotetext{
2 Het Planbureau voor de Leefomgeving gaf in een voorgaande evaluatie aan dat natuurlijke klimaatbuffers vaak last hebben van het innovatiedilemma. Na 2014 wordt het innovatiedilemma vaker overwonnen (bijvoorbeeld bij de Prins Hendrikzanddijk), het speelt echter nog steeds wel een rol (Markermeerdijk).
} 
Bijdragen van natuurlijke klimaatbuffers aan natuurdoelen

De twintig geëvalueerde natuurlijke klimaatbuffers laten vrijwel altijd herstel en ontwikkeling van habitats zien op projectniveau. In projecten die al enige jaren gerealiseerd zijn is het aantal flora- en faunasoorten toegenomen of zijn kwetsbare populaties versterkt. In sommige gevallen is er wel een verbetering bereikt, maar was de oorspronkelijke ambitie groter. Uit de beschikbare informatie is afgeleid dat met de eerste twintig projecten circa 20.000 hectare bestaande natuur in Nederland volgens het klimaatbuffer-principe is ingericht (4\% van het totale areaal natuur). Dit is inclusief naastgelegen natuurterreinen die meeprofiteren van lokale herstelmaatregelen. Daarbij is circa 2.000 hectare nieuwe natuur gerealiseerd in de periode 2008-2012.

Of de eerste twintig natuurlijke klimaatbuffers hebben geleid tot ecologisch systeemherstel op hoger systeemniveau (stroomgebied, waterbekken, etc.) is op dit moment nog niet te evalueren. Er moet eerst voldoende opschaling van lokale maatregelen gerealiseerd zijn. Bovendien heeft ecologische ontwikkeling tijd nodig. De resultaten van verschillende klimaatbuffers zijn soms wel aanleiding geweest voor de betrokken waterbeheerders om tot opschaling over te gaan.

Bij voldoende opschaling kan de heterogeniteit in het landschap toenemen, neemt de biodiversiteit toe en worden voedselwebben veerkrachtiger. Dat geldt voor alle typen klimaatbuffers: van Leuvenumse beek tot Oesterdam. Door de natuurlijke processen te stimuleren komen soorten ook onverwachts terug, zoals het klein zeegras in de Oosterschelde. Bij de klimaatbuffers in het rivierengebied is nu meer ruimte voor de bijbehorende natuurlijke processen, zoals natuurlijkere waterstanden en begrazing. Door wegzijging en het creëren van plasdras-situaties ontstaan er meer kansen voor laagdynamische natuur.

Bijdragen van natuurlijke klimaatbuffers aan economie - kosten

Er zijn steeds meer voorbeelden in het waterbeheer waarbij natuurlijke oplossingen ook daadwerkelijk kosten besparen. De kostenbesparingen die kwelders opleveren, als natuurlijk voorland van de dijk, zijn onlangs beter onderbouwd. De golfbelasting op een dijklichaam kan door een kwelder met wel $50 \%$ afnemen. Dat zorgt voor de belangrijkste kostenbesparing omdat een kleinere dimensionering van de dijk mogelijk is.

Uit de beschikbare informatie over de investeringskosten van waterberging rondom de stad gecombineerd met natuurontwikkeling is te concluderen dat deze variëren tussen 2 en 4 euro per $\mathrm{m}^{3}$ oppervlaktewaterberging. Kostenkengetallen zijn niet onderzocht of gevonden voor klimaatbuffers van het type Groene Airco, en Natuurlijke Spons en Koolstof-sink.

\section{Bijdragen van natuurlijke klimaatbuffers aan economie - baten}

Natuurlijke oplossingen zijn steeds vaker een volwaardig planalternatief. De baten van natuurlijke klimaatadaptatie-oplossingen voor recreatie, schelpdiersector, landbouw en drinkwaterwinning waren in de beschouwde projecten vaker doorslaggevend dan de kosten of kosteneffectiviteit.

Koolstofcertificaten kunnen een vorm van extra inkomsten zijn voor alle betrokken sectoren om koolstofneutraal beheer van land- of water te realiseren. Bij een gemiddelde $\mathrm{CO}_{2}$-prijs van $€ 5$ ton ${ }^{-1}$ $\mathrm{CO}_{2}$-eq (2018) op de vrije koolstofmarkt vertaalt dit zich naar een inkomen van €30-120 ha-1 $\mathrm{jr}^{-1}$. Carbon credits worden een aantrekkelijke financieringsbron voor hydrologische herstelmaatregelen wanneer de $\mathrm{CO}_{2}$-prijs stijgt naar $€ 10$ tot $€ 70$ per ton (Duits onderzoek). Er is een marge gegeven van de gewenste $\mathrm{CO}_{2}$-prijs omdat de investeringskosten per hectare sterk afhangen van de locatie.

\section{Succes- en faalfactoren}

Over succes- en faalfactoren bij het realiseren van (mee)koppelkansen voor water, klimaat en natuuropgaven in complexe gebiedsprojecten is al veel bekend, ook in het kader van natuurlijke klimaatbuffers. Uit de gesprekken met de projectleiders en stakeholders zijn negen generieke succesfactoren benoemd en zes faalfactoren. Dit is geen uitputtend overzicht. Het was opmerkelijk dat succesfactoren in sommige situaties ook faalfactoren kunnen zijn. Dat was het geval bij:

- Rekening houden met lokale wensen: draagvlak voor natuurlijke oplossingen wordt vergroot door rekening te houden met lokale wensen (succesfactor, voorbeeld: Prins Hendrikzanddijk), maar het kan ook natuurherstel bemoeilijken (voorbeeld: kite surfers bij de Oesterdam). 
- Afwegen van natuurbaten: het kan moeilijk zijn om alle positieve en negatieve effecten van natuurlijke oplossingen op verschillende typen natuur in een systeem af te wegen, zeker wanneer de maatregelen genomen worden op de grens van land en water, zee en kust, zoet en zout. Daardoor ervaart de één een natuurlijke oplossing als succes maar twijfelt de ander daarover.

- Het innovatiedilemma: volgens een PBL-evaluatie (2014) moet bij een urgente waterveiligheidsopgave de natuurlijke oplossing (het alternatief) voldoen aan hoge en te bewijzen waterveiligheidseisen. Dit creëert een klassiek innovatiedilemma, want zonder (geëvalueerde) praktijktoepassingen kan dat bewijs niet worden geleverd. Dit werd ook in 2019 genoemd als faalfactor, maar er is ook een kanteling gaande: steeds meer onderzoekresultaten onderschrijven de effectiviteit.

Er was consensus over de volgende succes- en faalfactoren:

- Het is belangrijk om doel en nevendoelen van een natuurlijke oplossing scherp te hebben in een planproces. Wanneer een tweede partij, naast de natuurterreinbeheerder, een belang heeft om een klimaat en/of natuuropgave te combineren, is dit een succesfactor. Zo'n 'tweede partij' met een natuurbelang was bijvoorbeeld Rijkswaterstaat (Rivierklimaatpark, Oesterdam), een waterschap/provincie (De Onlanden, Ilperveld, Anserveld-Leisloot) of een drinkwaterbedrijf (Hunze, Schoonwatervallei Castricum).

- Regelgeving (bijvoorbeeld Natura 2000) en financieringsritmes zijn faalfactoren. Het hoge marsritme binnen bijvoorbeeld het Hoogwaterbeschermingsprogramma (ambitie om 50 kilometer dijken te versterken per jaar) kan ertoe leiden dat niet alleen geld maar ook tijd een beperkende factor is voor het realiseren van natuurlijke oplossingen.

\section{Koppelkansen}

Het koppelen van natuuropgaven met waterberging in de Groenblauwe Ruimte is het meest succesvol geweest in regionale gebiedsontwikkeling binnen het CNK-programma. Deze evaluatie geeft aan dat de betrokken actoren in waterbeheer hier nog steeds veel perspectieven voor de toekomst zien. Ook op nationaal niveau groeit het besef om natuurontwikkeling te combineren met economische ontwikkeling of klimaatadaptatie. Een betere integratie van ruimtelijke opgaven komt steeds meer aan bod in het Deltaprogramma, het Natuurpact, het Klimaatakkoord, de Programmatische Aanpak Grote Wateren en Integraal Rivier Management.

\section{Koppelkansen met Deltaprogramma Zoetwater}

- In het landelijk gebied van Hoog-Nederland zijn koppelkansen mogelijk met het Deltaprogramma Zoetwater voor klimaatbuffers die zich richten op water vasthouden (de Natuurlijke Spons). De urgentie hiervan is door de droge zomers van 2018 en 2019 onderstreept.

- Natuurlijke oplossingen die waterconservering stimuleren op veen beschermen de koolstofvoorraad en kunnen in de toekomst zelfs koolstof vastleggen. Dit biedt koppelkansen tussen het Deltaprogramma en het Klimaatakkoord.

- De huidige woningbouwopgave betekent dat ook een groei van de drinkwatervoorraden noodzakelijk is. Dat kan een nieuwe functie zijn voor natuur in de Randstad. Er zijn al voorbeelden van natuurlijke klimaatbuffers die drinkwatervoorraden vergroten in de duinen en in Noord-Nederland.

- Het realiseren van gezamenlijke waterconservering voor landbouw en natuur is ook een kans.

\section{Koppelkansen met Deltaprogramma Ruimtelijke adaptatie}

- In het stedelijk gebied heeft de koppeling met natuurlijke oplossingen met een verkoelend effect (Groene Airco) en waterberging (Groenblauwe Ruimte) de meeste kans. Hoewel er in de stad, of aan de randen hiervan, niet altijd 'donkergroene natuur' mogelijk is, kunnen natuurlijke oplossingen rond de stad wel iets betekenen voor de leefkwaliteit, de basiskwaliteit van de biodiversiteit en publiek draagvlak voor natuurbeheer elders.

- Om ruimte te maken voor natuurlijke oplossingen moet worden aangesloten bij gemeenten die in 2019 in regionaal verband stresstesten afronden en worden gestart met oplossingsgerichte risicodialogen. 


\section{Koppelkansen met Deltaprogramma Waterveiligheid}

- Langs de kust en in de estuaria is veel ervaring opgedaan met natuurlijke oplossingen voor waterveiligheid. De aandacht ligt daarbij nog vooral op winst voor veiligheid, meer aandacht is nodig om ook de natuurwinst te valoriseren.

- Er liggen ook koppelkansen met het Klimaatakkoord omdat herstel van kwelders veel potenties heeft om broeikasgassen vast te leggen.

- Het programma Integraal Rivier Management, als ook de derde tranche voor Kaderrichtlijn Watermaatregelen, bieden kansen voor het koppelen van klimaatadaptatie met rivier-verruimende maatregelen met meerwaarde voor economie (scheepvaart, delfstofwinning, landbouw) en herstel van laag dynamische natuur in de uiterwaarden.

\section{Koppelkansen met de Programmatische Aanpak Grote Wateren (PAGW)}

- De PAGW biedt opschalings- en financieringsmogelijkheden voor klimaatbuffers die gericht zijn op natuurlijke oplossingen langs de kust (De Levende Kust, Biobouwers) in Waddenzee, Eems-Dollard, Oosterschelde, Westerschelde en maatregelen in het rivierensysteem.

- In samenwerking met LIFE IP Deltanatuur wordt gewerkt aan het Natuurwinstplan: een plan om een structurele oplossing te bedenken voor Natura 2000-knelpunten bij het realiseren van dynamische natuur. Dit maakt het ook voor natuurlijke klimaatbuffers makkelijker.

- Ook kwelderherstel is onderdeel van de PAGW; daarmee bestaan er ook koppelkansen tussen de PAGW en het Klimaatakkoord.

\section{Koppelkansen met het Klimaatakkoord}

- In het Klimaatakkoord ligt een opgave voor broeikasgasemissiereductie voor landgebruik in bos en natuur ( 0,4 tot 0,8 Mton) en in veenweiden (1,0 Mton), te realiseren voor 2030 . Het maatschappelijk rendement kan vergroot worden wanneer het vastleggen of reduceren van landgebonden broeikasgassen gecombineerd wordt met water vasthouden en water bergen ('klimaat in het kwadraat'). Het Klimaatakkoord geeft ook een nieuwe impuls aan het afmaken van het Natuurnetwerk Nederland en het verdrogingsherstelbeleid.

- Met de ontwikkeling van natte natuur in combinatie met natuurinclusieve (natte) landbouw is een groot deel van de bovengenoemde emissiereductie-opgave realiseerbaar op veen, moerige grond en minerale gronden (klein aandeel, o.a. ooibossen). De bijdrage van koolstofvastlegging in kwelders in de Eems-Dollard, Zeeuwse en Zuid-Hollandse Delta en Waddenzee is groot per hectare, maar het areaal kwelders is in Nederland relatief klein (10.000 ha) ten opzichte van het areaal overige natte natuur.

- Met natte natuur en natuurinclusieve landbouw kan het landgebruik emissieneutraal worden of zelfs netto koolstof opslaan. Een deel van die ambitie is al vastgelegd in het Klimaatakkoord. Er is echter tijd nodig om voor deze ambitie maatschappelijk draagvlak te vinden.

\section{Koppelkansen met het bedrijfsleven}

- Koolstofcertificaten kunnen een financieringsmodel zijn om beheer en onderhoud van toekomstige klimaatbuffers mede te financieren op de vrijwillige koolstofmarkt. Het maakt daarbij niet uit of de beheerder een natuurterreinbeheerder, agrarisch ondernemer of waterbeheerder is. Wel moet de betreffende $\mathrm{CO}_{2}$-reductie additioneel zijn aan geïnstrumenteerd beleid.

- Het is nog een uitdaging om natuurlijke oplossingen, gericht op klimaatadaptatie, in te bedden in de bedrijfsvoering van bijvoorbeeld de voedselverwerkende industrie, de financiële sector of havenbedrijven. Maar de mitigatiepotenties van maatregelen kunnen wel helpen om een deel van het financiële risico van een investering in klimaatadaptatie of biodiversiteitsherstel te dekken en in de tijd te spreiden

- Gegeven de droogte- en stikstofproblematiek is het essentieel om met de landbouw meer samen te werken, bijvoorbeeld in het Deltaplan Agrarisch Waterbeheer.

- Voor beleggingsfondsen en banken zijn de huidige klimaatbuffer-projecten vaak te klein om in te financieren. Het is voor hen ook onduidelijk bij wie het rendement van natuurlijke klimaatbuffers terechtkomt wanneer meerdere partijen betrokken zijn. Terwijl het delen van de investeringskosten juist als een succesfactor wordt gezien bij regionale overheden. Aan de andere kant krijgen verzekeraars en sommige banken steeds meer aandacht voor klimaatadaptatie, waterkwaliteit en biodiversiteit. Het Verbond van Verzekeraars doet bijvoorbeeld nader onderzoek naar preventieve maatregelen voor wateroverlast en droogte bij huis- en landeigenaren. Natuurlijke oplossingen 
kunnen schadeclaims beheersbaar houden voor verzekeraars en het restrisico verzekerbaar houden voor land- of huiseigenaren.

Inbedden van natuurlijke oplossingen in waterbeheer en ruimtelijke ontwikkeling

Een succesvolle inbedding betekent dat natuurorganisaties, Rijkswaterstaat, waterschappen, provincies, gemeenten en economische gebruikers (o.a. landbouw, drinkwaterbedrijven) het klimaatbuffer-principe als vanzelfsprekend toepassen wanneer zij nadenken over klimaatadaptatie op hun eigen terrein en/of meedenken over oplossingen of plan-alternatieven met anderen in een groter gebied. De Rijksoverheid (LNV, I\&W, EZK) speelt ook een sleutelrol: zij kan de randvoorwaarden scheppen en dit type maatregelen faciliteren.

"In 2022 zijn natuurlijke klimaatbuffers vanzelfsprekend geworden. De transitie naar natuurlijke oplossingen die bijdragen aan klimaatbestendigheid èn biodiversiteit is daarmee een grote stap verder en onze leerervaringen zijn gedeeld met anderen." (Missie CNK)

Deze evaluatie laat zien dat het principe van natuurlijke klimaatbuffers inmiddels de pilotfase wel voorbij is. Het inbedden komt dus langzaam maar zeker op stoom; er is significante vooruitgang geboekt sinds de voorgaande evaluaties uit 2014. De missie van de CNK is nog niet op alle punten gehaald maar is wel realiseerbaar. Niet elk type natuurlijke oplossing wordt al als vanzelfsprekend beschouwd. Het combineren van waterberging rondom steden met natuurontwikkeling is een voorbeeld van een frontrunner, terwijl het werken met verschillende typen biobouwers nog in de experimentele fase zit. Er zijn een groot aantal succesvolle lokale initiatieven gerealiseerd. Steeds meer provincies en waterschappen presenteren samen met natuurorganisaties planalternatieven die geïnspireerd zijn op natuurlijke processen en de ambitie hebben om ook natuurwaarden te vergroten. Daarbij maakt het niet uit of die projecten ook het label van 'natuurlijke klimaatbuffer' dragen. Een uitdaging is nog hoe tussen 2019 en 2022 van een breed scala succesvolle initiatieven de stap wordt gemaakt naar een samenhangende aanpak op nationaal niveau. Er zijn geen nieuwe succes- en faalfactoren boven water gekomen bij de introductie van natuurlijke oplossingen. Wel worden de betrokkenen, door leerervaringen, steeds inventiever om het risico op een mislukking te verkleinen en de kans op succes te vergroten. Wij doen een aantal aanbevelingen om de missie te realiseren:

\section{1) Gebruik toekomstige gebiedsontwikkelingen als vliegwiel}

De Nationale Omgevingsvisie (NOVI) richt zich op klimaatadaptatie, energietransitie (windmolens, aardgasvrije woningen), verduurzaming van de Nederlandse economie met behoud van groeipotentieel en een toekomstbestendig landelijk gebied. De hiervan afgeleide regionale omgevingsvisies die provincies en gemeenten moeten opstellen bieden koppelkansen voor natuurlijke oplossingen.

- Deel ervaringen in Policy Learning Groups: er zijn veel geslaagde projecten die een 'proof of concept' kunnen zijn voor provincies en/of gemeenten. Om ervaringen te delen kunnen Policy Learning Groups opgezet worden, bijvoorbeeld in samenwerking met STOWA en de commissie MER.

- Maak een inhaalslag richting de stad met een lerende pilot: de aanbeveling is om met een lerende pilot te verkennen welke mogelijke rol natuurlijke klimaatbuffers in/rondom de stad kunnen spelen en welke rol natuurorganisaties daarin wel of niet willen nemen.

- Ontsluit en actualiseer de opgedane ervaring met klimaatbuffers rondom de stad: het gaat dan om klimaatbuffers met waterberging expliciet voor de doelgroepen in het peri-urbane gebied.

Ervaringen kunnen ook worden toegevoegd aan de website van het Deltaprogramma Ruimtelijke adaptatie of worden gedeeld tijdens een kennisdag met partijen zoals STOWA, het Klimaatverbond voor Gemeenten en BIJ12.

- Blijf doelen combineren: de ervaringen laten zien dat doelen combineren, ondanks complexiteit, een kans bieden om meer draagvlak te krijgen voor een klimaatbuffer-project.

\section{2) Gebruik toekomstige klimaatopgaven op nationaal niveau}

Het tweede vliegwiel zijn de klimaatopgaven die op nationaal niveau zijn beschreven maar die op een regionaal niveau moeten worden opgelost. Daarbij is het behulpzaam wanneer er meer top-downverankering is van natuurlijke oplossingen in de planvorming:

- Maak geld vrij uit een stimuleringsfonds: of gebruik een budgetallocatie binnen het Deltafonds. Met deze middelen kan worden gezorgd dat kleinschalige natuurherstelmaatregelen die bijdragen aan 
waterveiligheid (bijvoorbeeld pilots met voor- en achteroevers), na de pilotfase, ook daadwerkelijk worden opgeschaald.

- Neem natuurlijke oplossingen als standaard mee bij het opstellen van MER-Startnotities.

- Start een ontwerpatelier Klimaat-Ruimte-Biodiversiteit: daarin kan verkend worden hoe landelijke doelstellingen voor klimaatadaptatie, natuuropgaven en ruimtelijke kwaliteit gecombineerd en in samenhang op nationaal niveau uit te werken zijn. Zo is het interessant om te kijken of de opgave binnen het Natuurnetwerk Nederland ( 80.000 hectare nieuwe natuur) te realiseren is samen met het vastleggen van landgebruikgebonden broeikasgassen, doelen voor het realiseren van natuurinclusieve landbouw en het leggen van verbindingen tussen regionale en rijkswateren. Ook het Natuurwinstplan biedt aanknopingspunten.

3) Samenwerken met de private sector

- Om te komen tot een inrichting van Nederland die beter gebruikmaakt van natuurlijke processen moet het bedrijfsleven beter betrokken worden. Deze evaluatie laat zien dat private sectoren hiervoor steeds meer open staan. Het is een aanbeveling om de samenwerking met de drinkwaterbedrijven, landbouw, voedselverwerkende industrie en financiële sector te zoeken, bijvoorbeeld in het kader van onderzoek in het topsectorenbeleid.

4) Lerend implementeren samen met onderzoek, beleid en bedrijfsleven Lerend implementeren is een manier om innovatiedilemma's te overwinnen en het draagvlak voor het klimaatbuffer-principe te vergroten. Het betekent onder andere dat onderzoekers en stakeholders betrokken worden bij de monitoring van de effecten van maatregelen die water- of natuurbeheerders nemen, en dat hieruit gezamenlijk conclusies worden getrokken. Recente voorbeelden van projecten, buiten het CNK-programma, waar 'lerend implementeren' is toegepast, zijn de Zandmotor, onderzoek naar beekdalherstel binnen het Kennisprogramma Lumbricus en de aanleg van de Marker Wadden. Op basis van de ervaringen hieruit, kan het CNK-programma doorborduren. 


\section{$1 \quad$ Introductie}

\section{$1.1 \quad$ Achtergrond}

Sinds 2008 heeft de Coalitie Natuurlijke Klimaatbuffers (CNK) meer dan 70 natuurlijke klimaatbuffers ${ }^{3}$ gerealiseerd, waarvan twintig gebiedsprojecten in de eerste tranche (2008-2012). Ze liggen verspreid over heel Nederland en zijn gerealiseerd in samenwerking met het Rijk, provincies, waterschappen en gemeenten, eigen middelen en financiering van bijvoorbeeld de Postcode Loterij.

Natuurlijke klimaatbuffers zijn gebieden waar natuurlijke processen de ruimte krijgen. Hierdoor groeien ze mee met klimaatverandering en vervullen ze een rol bij het vasthouden en opvangen van water, het voorkomen van watertekorten, het temperen van hitte en het verminderen van kooldioxide in de atmosfeer. Zo verbeteren ze de leefbaarheid van Nederland (CNK 2019).

Een evaluatie van het Planbureau voor de Leefomgeving (PBL) uit 2014 stelt dat het concept 'natuurlijke klimaatbuffer' een groot potentieel heeft voor bredere toepassing in verschillende beleidsdomeinen (Smit et al. 2014). Aanvullende evaluaties geven bovendien aan dat klimaatbuffers geld kunnen besparen ten opzichte van traditionele oplossingen (Sterk Consulting 2014) en dat er meekoppelkansen zijn in het nationale en regionale waterbeheer (Van Hattum et al. 2014).

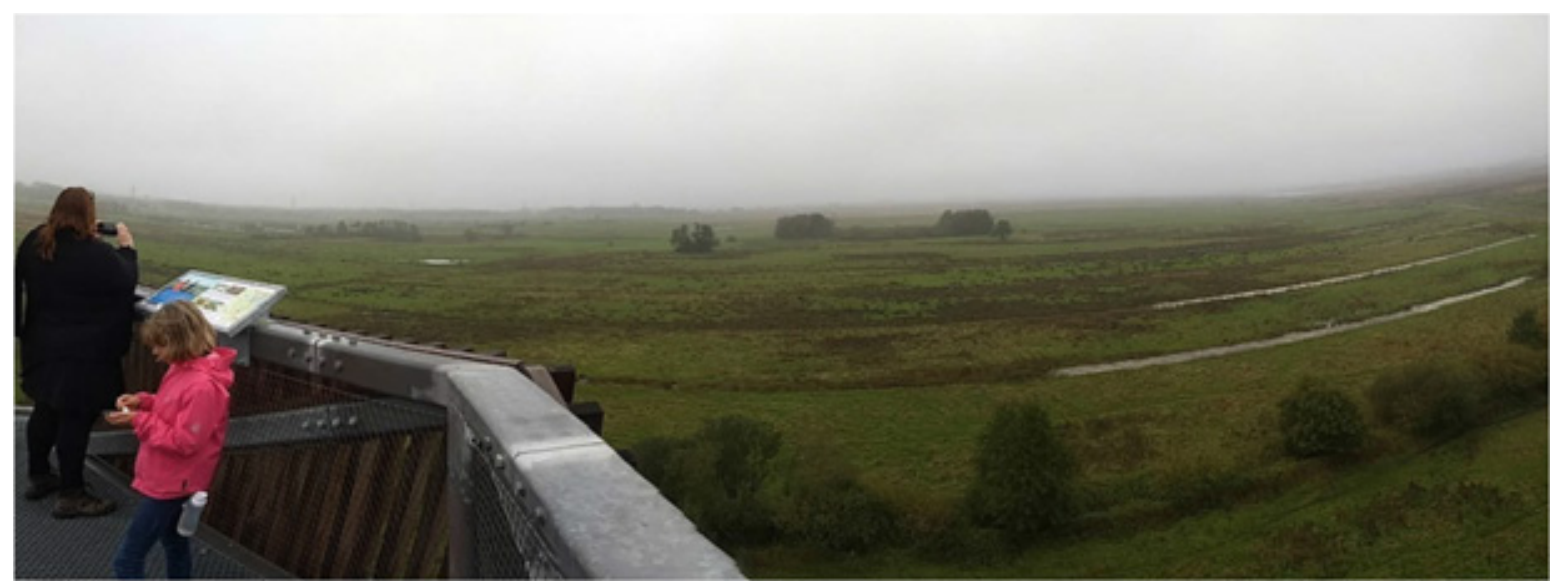

Uitzicht over de Onlanden (Foto: Paul Vertegaal, Natuurmonumenten, oktober 2019).

Desondanks worden natuurlijke oplossingen nog niet altijd automatisch meegenomen bij beslissingen over het aanpakken van klimaatopgaven waar het Rijk, provincies, gemeenten en waterschappen voor staan. In het kader van het programma LIFE-IP Deltanatuur zet de CNK zich in om de klimaatbufferaanpak als standaard optie in te bedden in ruimtelijk beleid en in water- en natuurbeheer.

Er zijn in Nederland nog veel meer mogelijkheden om met natuurlijke klimaatbuffers aan de slag te gaan waarbij er meekoppelkansen liggen in het waterbeheer maar ook het Nederlandse klimaatbeleid. Veel van deze nieuwe kansen liggen in of langs de rijkswateren en in Natura 2000-gebieden. De CNK formuleert in haar meest recente visie: "In 2022 zijn klimaatbuffers vanzelfsprekend geworden. De transitie naar natuurlijke oplossingen die bijdragen aan klimaatbestendigheid èn biodiversiteit is daarmee een grote stap verder en onze leerervaringen zijn gedeeld met anderen."

In het kader van LIFE-IP Deltanatuur (LIFE IP Consortium 2016) zet de CNK zich in om de klimaatbuffer-aanpak als standaard optie in te bedden (te 'mainstreamen') in ruimtelijk beleid en de

\footnotetext{
3 In het vervolg van de tekst wordt de quote 'natuurlijke klimaatbuffers' afgekort als KB-projecten.
} 
dagelijkse praktijk van water- en natuurbeheer. Met het oog daarop heeft de CNK een opdracht geformuleerd voor een 'grondige evaluatie' van uitgevoerde KB-projecten, met de nadruk op het proces en governance-aspecten. In de nadere opdrachtomschrijving is aangegeven dat de analyse zich moet richten op vijf criteria: (a) succes- en faalfactoren, (b) bijdrage aan klimaatadaptatie en -mitigatie, (c) kosten en baten (d) klimaatbuffers in beleid en (e) het natuurrendement van klimaatbuffers.

\subsection{Evaluatiedoelen}

De evaluatie heeft zich gericht op de volgende hoofddoelen:

- verkrijgen van een geactualiseerd overzicht van de bijdragen van klimaatbuffers aan klimaatbeleid, natuurdoelen en economie per type natuurlijke klimaatbuffer ${ }^{4}$;

- trekken van lessen uit succes- en faalfactoren bij het opstarten en uitvoeren van klimaatbuffers;

- benoemen van (mee)koppelkansen;

- Aanbevelingen voor het inbedden van natuurlijke oplossingen in waterbeheer en ruimtelijke ordening.

De vijf evaluatiecriteria van de CNK worden behandeld volgens het overzicht in tabel 1.1.

Tabel 1.1 Omschrijving van de evaluatiecriteria.

\begin{tabular}{|c|c|c|}
\hline Evaluatiecriterium & Vraag CNK & Aanpak \\
\hline \multicolumn{3}{|l|}{ Rendement } \\
\hline Klimaat & $\begin{array}{l}\text { Welke bijdrage leveren de afzonderlijke } \\
\text { klimaatbuffers aan klimaatadaptatie en - } \\
\text { mitigatie, nu en in de toekomst? }\end{array}$ & $\begin{array}{l}\text { In de evaluatie is onderscheid gemaakt in } \\
\text { waterberging, waterconservering, } \\
\text { verkoeling, kustbescherming, } \\
\left.\text { broeikasgasemissiereductie ( } \mathrm{CO}_{2}-\mathrm{eq}\right) \text { en } \\
\text { koolstofvoorraad. }\end{array}$ \\
\hline Natuur & $\begin{array}{l}\text { Wat is de natuuropbrengst (invulling van de } \\
\text { natuurdoelen/-opgaven), naast de opbrengst } \\
\text { van de wateropgaven? }\end{array}$ & $\begin{array}{l}\text { Er is in de interviews gevraagd naar het } \\
\text { natuurrendement en er is aanvullend } \\
\text { literatuuronderzoek gedaan. }\end{array}$ \\
\hline Economie & $\begin{array}{l}\text { Wat zijn de kosten en baten van } \\
\text { klimaatbuffers, i.r.t. andere maatregelen? Hoe } \\
\text { (en hoeveel) dragen ze bij aan andere } \\
\text { prioritaire omgevingsopgaven? }\end{array}$ & $\begin{array}{l}\text { Voor elk type klimaatbuffer zijn } \\
\text { bestaande inventarisaties van } \\
\text { kengetallen (Sterk Consulting 2014) } \\
\text { aangevuld met de ervaringen genoemd } \\
\text { tijdens de interviews. }\end{array}$ \\
\hline \multicolumn{3}{|l|}{ Proces en governance } \\
\hline Succes- \& faalfactoren & $\begin{array}{l}\text { Wat zijn succes- en faalfactoren voor het } \\
\text { realiseren van natuurlijke klimaatbuffers? }\end{array}$ & $\begin{array}{l}\text { Ervaringen zijn opgehaald tijdens de } \\
\text { interviews met projectleiders en binnen } \\
\text { de omgevingsscan (interviews, } \\
\text { workshop). De succes- en faalfactoren } \\
\text { zijn op een rij gezet en vergeleken met } \\
\text { voorgaande evaluaties. }\end{array}$ \\
\hline Klimaatbuffers in beleid & $\begin{array}{l}\text { Op welke manier is de klimaatbufferaanpak } \\
\text { ingebed in de huidige beleidspraktijk? Wat } \\
\text { lijken de meest kansrijke en effectieve } \\
\text { aangrijpingspunten voor beleidsverandering? }\end{array}$ & $\begin{array}{l}\text { Ervaringen zijn opgehaald tijdens de } \\
\text { interviews, omgevingsscan en workshop. } \\
\text { Op basis van de resultaten zijn } \\
\text { koppelkansen geïdentificeerd. }\end{array}$ \\
\hline
\end{tabular}

\footnotetext{
4 Spons, Groenblauwe ruimte, Koolstof-sink, Groene Airco, Levende Kust, Biobouwers.
} 


\subsection{Leeswijzer}

Het rapport begint met drie introducerende hoofdstukken. Daarna worden de resultaten uit de verschillende projectactiviteiten omschreven en de laatste drie hoofdstukken zijn gericht op het beantwoorden van de evaluatievragen.

Introducerende hoofdstukken

Hoofdstuk 1 De evaluatiedoelen en de achtergrond van de evaluatie.

Hoofdstuk 2 Toelichting op de aanpak van de evaluatie.

Hoofdstuk 3 Omschrijving van het programma Natuurlijke Klimaatbuffers. Hoe is het programma georganiseerd, hoe heeft het programma zich ontwikkeld sinds 2008 en wat schrijven eerdere evaluaties?

Onderzoeksresultaten uit projectactiviteiten

Hoofdstuk $4 \quad$ Interviews met projectleiders van geselecteerde klimaatbuffers.

Hoofdstuk 5 Deskstudie: aanvullingen op de interviews voor de criteria klimaat, natuur en economie geclusterd naar de typen klimaatbuffers.

Hoofdstuk 6 Omgevingsscan: wat vinden stakeholders van de klimaatbuffer-aanpak?

\section{Synthese}

Hoofdstuk 7

Conclusies over succes- en faalfactoren.

Hoofdstuk 8 Conclusies over meekoppelkansen.

Hoofdstuk 9

Aanbevelingen om het principe van natuurlijke klimaatbuffers in te bedden in beleid (mainstreamen). 


\section{Evaluatiemethode}

\section{$2.1 \quad$ Introductie}

In deze evaluatie is het accent gelegd op de beleidscontext waarbinnen het werk aan natuurlijke klimaatbuffers zich beweegt. Daarom is een omgevingsscan uitgevoerd bij overheden en stakeholders van natuurlijke klimaatbuffers, door middel van interviews en een bijeenkomst met vertegenwoordigers hiervan.

Daarna zijn CNK-projectleiders van zeven klimaatbufferprojecten geïnterviewd om in beeld te brengen welke meekoppelkansen, succes- en faalfactoren zij ervaren bij het realiseren van KB-projecten en hoe zij de effectiviteit van de maatregelen inschatten.

Voorafgaand en na afloop van de omgevingsscan en de interviews met de projectleiders is de deskstudie uitgevoerd. Binnen de deskstudie zijn ervaringen van projectleiders en stakeholders, waar mogelijk, geverifieerd in de literatuur en aangevuld met ervaringen uit klimaatbufferprojecten waarmee geen interview is gedaan.

De resultaten van de omgevingsscan, de interviews en de deskstudie zijn gecombineerd om in beeld te brengen hoe:

- klimaatbuffers effectiever kunnen worden ingezet voor klimaatbeleid, natuurdoelen en economie (hoofdstuk 5);

- kan worden omgegaan met faal- en succesfactoren (hoofdstuk 7);

- meekoppelkansen beter kunnen worden benut (hoofdstuk 8).

Tot slot is op basis van dit alles een advies geformuleerd om het concept van natuurlijke klimaatbuffers beter in te bedden in het ruimtelijk beleid (hoofdstuk 9). Dit zijn de vier hoofddoelen van deze evaluatie.

Figuur 2.1 illustreert deze methode en hoe deze leidt tot beantwoording van de vier hoofddoelen.

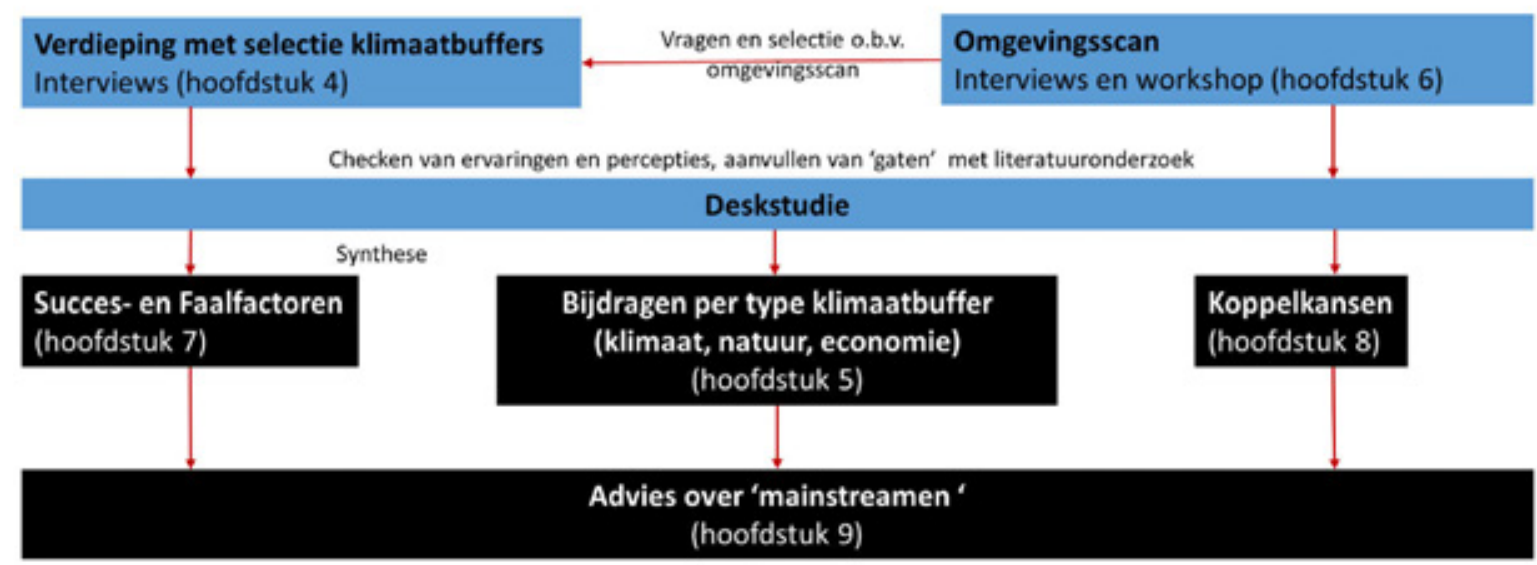

Figuur 2.1 Flowdiagram van de evaluatie. 


\subsection{Deskstudie}

Vlak na realisatie van de eerste klimaatbuffers zijn de verwachtingen gerapporteerd (CNK 2012) en zijn kennisinventarisaties gemaakt (CNK 2014). Binnen deze deskstudie zijn deze verwachtingen uit deze twee bronnen op een rij gezet. Het gaat dan om de verwachte bijdragen van klimaatbuffers aan klimaatbeleid, natuurdoelen en economie, de verwachte succes- en faalfactoren en meekoppelkansen. Dit overzicht is gemaakt voor de eerste twintig KB-projecten (gebiedsprojecten) die uitgevoerd zijn tussen 2008 en 2014 (figuur 2.2). Er staan extra punten op de kaart. Het project Ilperveld viel in de periode 2008-2014 niet onder het Programma Natuurlijke Klimaatbuffers maar is wel op de kaart geplaatst en meegenomen in de evaluatie. De projecten prins Hendrik Zanddijk, Rijnstrangen waren, bij aanvang, strategische projecten en zijn na 2014 pas gebiedsprojecten geworden. Het project Smart Rivers richt zich op kennisuitwisseling en heeft daarmee een uitzonderingspositie. De deelprojecten bij de Hunze zijn gezamenlijk geëvalueerd.

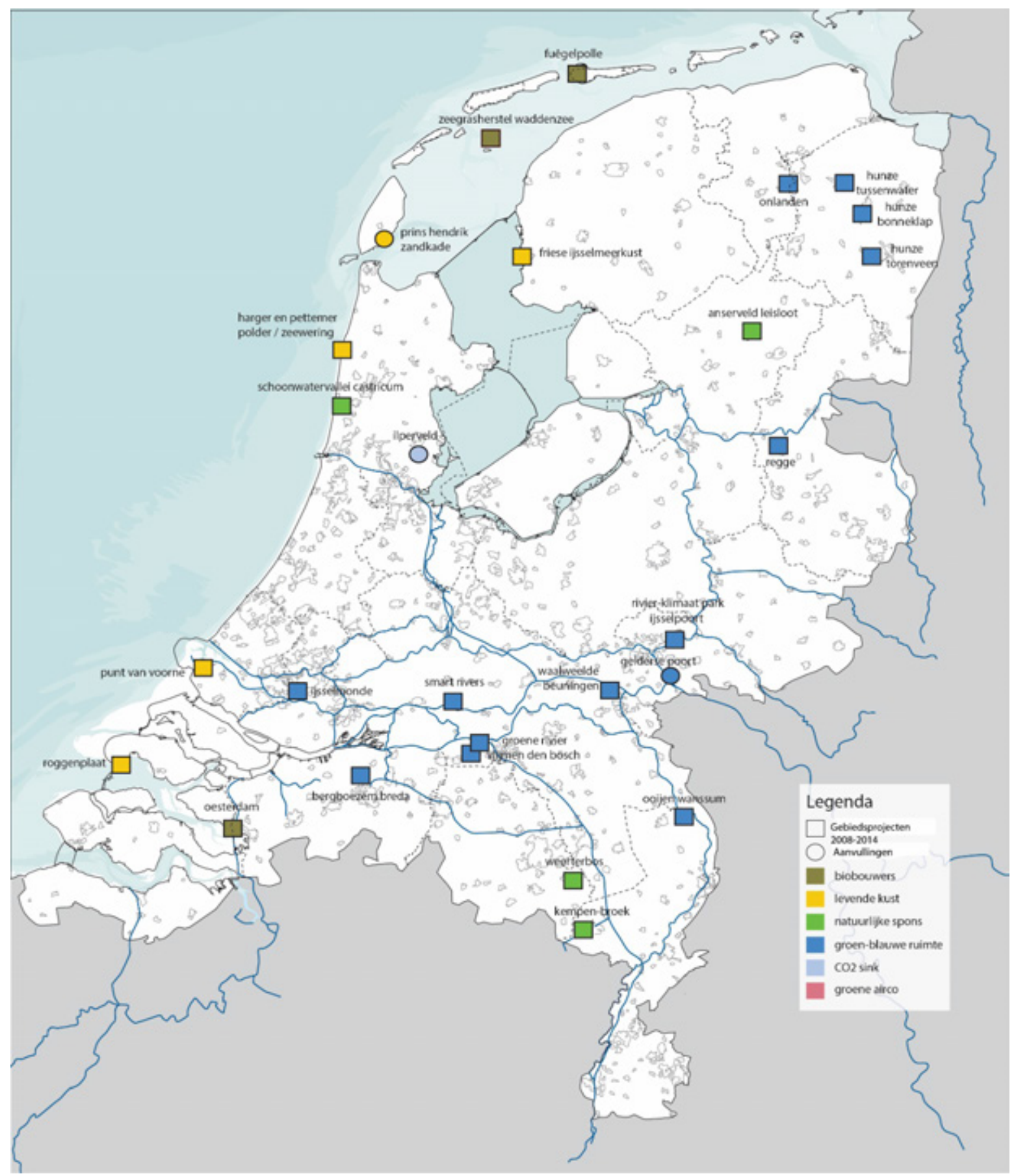

Figuur 2.2 Overzicht van de klimaatbufferprojecten die gestart zijn in de periode 2008-2014 en enkele aanvullingen. 
Daarna zijn de omgevingsscan en de gesprekken met de projectleiders uitgevoerd. Vervolgens is de deskstudie hervat om de resultaten uit de drie voorgaande activiteiten te integreren om uitspraken te kunnen doen per evaluatiecriterium. Hieronder staat omschreven hoe de evaluatiecriteria in de analyse zijn gebruikt.

Klimaat

Bij het criterium klimaat is er in de deskstudie onderscheid gemaakt tussen klimaatadaptatie en -mitigatie.

\section{Klimaatadaptatie}

Eerst zijn overzichtskaarten gemaakt van de vooraf verwachte effecten van de twintig KB-projecten op het gebied van waterberging (oppervlaktewater) en waterconservering (water vasthouden in bodem en grondwater) en daarvan afgeleide indicatoren zoals risico op wateroverlast of droogte. De overige aspecten van klimaatadaptatie die vooraf verwacht werden zijn alleen kwalitatief op een rij gezet. Met literatuuronderzoek is gekeken of er ook effecten in onderzoek of monitoring bekend zijn.

\section{Klimaatmitigatie}

Er is vooraf geïnventariseerd welke broeikasgasemissiefactoren gebruikt worden in klimaatbeleid. Ook zijn in andere studies broeikasgasemissies gemeten op locaties in Nederland die vergelijkbaar zijn met vier KB-projecten: De Onlanden, Ilperveld, Anserveld/Leisloot en Hunze. Voor deze vier klimaatbuffers is een hypothese geformuleerd over de realiseerbare minimale en maximale jaarlijkse broeikasgasreductie, gebaseerd op de gevonden emissiefactoren uit de literatuur en de oppervlakte van de klimaatbuffer, gecorrigeerd voor aan-/afwezigheid van veen en de mate van drooglegging in de nul-situatie. De broeikasgasreductie wordt uitgedrukt als (kiloton) $\mathrm{CO}_{2}$-equivalent, oftewel de uitstoot omgerekend naar $\mathrm{CO}_{2}$ - uitstoot.

$\mathrm{Er}$ is literatuuronderzoek gedaan naar de koolstofprijs. Dit geeft een indicatie van de economische waarde van de potentieel gerealiseerde reductie van broeikasgasemissie. De indicaties worden in zowel de emissie- als waardebepaling gegeven in bandbreedtes die recht doen aan de onzekerheden.

\section{Natuur}

De vooraf beoogde ecologische effecten van de maatregelen in de twintig eerste natuurlijke klimaatbuffers zijn op een rij gezet in een Excel sheet. Op een kaart zijn deze effecten voor alle klimaatbuffers weergegeven als land- en waternatuur. Op basis van informatie beschikbaar op internet is ook een inschatting gemaakt van het oppervlakte natuurterrein van elke klimaatbuffer. Voor de zeven geselecteerde klimaatbuffers is literatuuronderzoek gedaan om te achterhalen of er na realisatie van de maatregelen ook al daadwerkelijk ecologische effecten gerapporteerd zijn.

\section{Economie}

In de literatuur is weinig kwantitatieve financiële informatie (kosten) beschikbaar over het verschil tussen 'bouwen met natuur' (of het realiseren van wateropgaven in combinatie met natuurdoelen) en traditionele alternatieven voor deze doelen (Sterk Consulting 2014). Er is voor de zeven geselecteerde klimaatbuffers gekeken of er sinds 2014 nieuwe inzichten zijn gepubliceerd over de kosten en baten van het concept natuurlijke klimaatbuffers op het gebied van waterberging, vastlegging van broeikasgassen en waterveiligheid (Oesterdam).

\section{Succes- en faalfactoren}

De generieke conclusies uit eerdere evaluaties (hoofdstuk 3.3) over succes en faalfactoren zijn op een rij gezet. Deze zijn vergeleken met de uitspraken hierover van respondenten en workshop deelnemers binnen onze evaluatie om te analyseren of er voortschrijdende inzichten zijn.

\section{Meekoppelkansen}

De definitie van meekoppelen kan verschillen per beleidsdomein. In het Hoogwaterbeschermingsprogramma (HWBP) spreekt men bijvoorbeeld vaak over 'werk met werk' maken (Van Popering-Verkerk and Van Buuren 2016). Dat betekent bijvoorbeeld dat het ontgonnen zand bij het realiseren van een nevengeul meteen wordt gebruikt voor een ander project in de buurt dat zand nodig heeft. Het is een praktische invulling van meekoppelen. Het Deltaprogramma 
Ruimtelijke adaptatie ziet de verbinding tussen waterbeheer en ruimtelijke ontwikkeling als meekoppelen. Het 'Building with nature' programma omschrijft 'meekoppelen van water en natuur' als een ecologische aanpak van wateropgaven, waarbij gebruik gemaakt wordt van natuurlijke processen om wateropgaven te kunnen realiseren (De Vriend and Van Koningsveld 2012).

Onder meekoppelen van water-, klimaat- en natuuropgaven wordt in dit onderzoek verstaan het koppelen $^{5}$ van natuurdoelen met beleidsopgaven op het terrein van klimaatbeleid (mitigatie en adaptatie) en waterbeleid (waterveiligheid, wateroverlast, zoetwatervoorziening of waterkwaliteit). Deze opgaven worden dus als gelijkwaardig beschouwd. In de interviews en workshops met de KB-projectleiders en de stakeholders zijn allerlei meekoppelkansen met beleidsvelden, economische sectoren en onderzoeksprogramma's benoemd. In de deskstudie is deze opbrengst geclusterd en gerangschikt en vergeleken met conclusies hierover uit eerdere evaluaties.

\section{Mainstreamen}

Mainstreamen is te omschrijven als een inspanning gericht op het inbedden van klimaatadaptatie in sectoraal beleid of investeringsbeslissingen, bijvoorbeeld ten aanzien van infrastructuur, landbouw, woningbouw of natuurontwikkeling (Brouwer et al. 2013; Uittenbroek et al. 2013). Wanneer dit inbedden succesvol is dan is er theoretisch geen apart beleid meer nodig voor klimaatadaptatie. Ook de ambitie van de CNK om het klimaatbuffer-concept als volwaardig plan-alternatief in waterbeheer en ruimtelijk beleid te positioneren kan gezien worden als een vorm van 'mainstreamen'. In de evaluatie wordt gekeken hoe dat 'mainstreamen' op dit moment verloopt en worden aanbevelingen gedaan hoe mainstreamen versneld kan worden in het waterbeheer, het ruimtelijk beleid en economische sectoren.

\subsection{De omgevingsscan}

In deze omgevingsscan zijn overheden en maatschappelijke partijen geconsulteerd die een sleutelrol kunnen hebben bij het bedenken, uitvoeren of financieren van klimaatbufferprojecten. Er is rekening gehouden met het feit dat er ook eerder stakeholderanalyses zijn uitgevoerd voor het klimaatbufferprogramma.

\subsubsection{Interviews}

Er zijn twaalf respondenten gekozen waarmee de CNK al goede relaties heeft. Daarnaast is met een aantal mensen gesproken die, tot nu toe, geen directe betrokkenheid heeft gehad bij natuurlijke klimaatbuffers (tabel 2.1). Deze tweede groep respondenten heeft affiniteit met het gedachtengoed van natuurlijke klimaatbuffers en is in de positie om hieraan ook bij te dragen. Met de gesprekken zijn ideeën opgehaald voor het inbedden van natuurlijke klimaatbuffers in het waterbeheer en ruimtelijk beleid. De gevoerde gesprekken waren niet bedoeld om een representatief beeld van het totale krachtenveld te schetsen.

Tabel 2.1 De geïnterviewde stakeholders van de omgevingsscan.

\begin{tabular}{lll} 
Organisatie & Functie & Relatie met klimaatbuffers \\
Politieke partij (GroenLinks) & Lid Tweede Kamer & Geen betrokkenheid \\
\hline Deltaprogramma (Ruimtelijke adaptatie) & Lid stuurgroep, bestuur waterschap & Betrokken geweest bij 1 KB \\
\hline Ministerie van LNV & Ambtenaar (directeur) & Indirect betrokken (rijkswateren) \\
\hline Provincie Noord-Brabant & Beleidsmedewerker & Ermee bekend \\
\hline Rijkswaterstaat & Medewerker ecologie & Betrokken bij 2 KB's \\
\hline Waterschap Aa en Maas & Bestuurder & Betrokken bij $1 \mathrm{~KB}$ \\
\hline STOWA & Bestuurder & Ermee bekend \\
\hline Stichting Ecoshape & Bestuurder & Betrokken geweest \\
\hline Nationaal Groenfonds & Medewerker & Geen betrokkenheid \\
\hline Pensioenfonds & Medewerker & Geen betrokkenheid \\
\hline Topsector Water & Bestuurder & Geen betrokkenheid \\
\hline Gemeente Rotterdam & Strateeg klimaat & Geen betrokkenheid
\end{tabular}

5 We spreken in dit onderzoek liever over koppelen in plaats van meekoppelen omdat het op deze manier natuuropgaven gelijkwaardig worden beschouwd in vergelijk tot de overige opgaven in een gebied. 
Tijdens de interviews zijn de volgende vragen gebruikt:

- Wat verstaan de respondenten onder het concept natuurlijke klimaatbuffers?

- Wat vinden ze van uitgevoerde projecten en hun betrokkenheid tot nu toe?

- Waar liggen kansen voor nieuwe klimaatbuffers?

- Aan welke doelen moeten klimaatbuffers bijdragen?

- Wil je betrokken zijn? En zo ja, hoe?

- Wat zijn drempels die voorkomen dat natuurlijke klimaatbuffers van de grond komen?

- Welke stimulansen zie je die het inbedden van natuurlijke klimaatbuffers kunnen vergroten?

- Hoe ziet de toekomst voor natuurlijke klimaatbuffers eruit?

\subsubsection{Bijeenkomsten}

In een Toetsbijeenkomst zijn de eerste conclusies en aanbevelingen uit de omgevingsscan besproken met stakeholders (25 april 2019, Amersfoort). Hierbij waren vertegenwoordigers aanwezig van Waterschappen, Provincies, het Rijk, natuurterreinbeheerders en kennisinstellingen. Daarnaast zijn de conclusies en aanbevelingen ook voorgelegd aan het kennisnetwerk van het Deltaprogramma (10 mei 2019) en zijn er twee werksessies geweest met de partners van de Coalitie Natuurlijke Klimaatbuffers (14 maart 2019; 27 mei 2019).

\subsection{Verdieping met geselecteerde klimaatbuffers}

In overleg met de CNK zijn zeven natuurlijke klimaatbufferprojecten gekozen voor een verdieping. De projectleiders zijn geïnterviewd om inzichten over de bijdragen (klimaat, natuur, economie), meekoppelkansen, succes- en faalfactoren te actualiseren per type klimaatbuffer (figuur 2.3). Er is geen projectleider geïnterviewd over het klimaatbuffertype 'Levende Kust', maar ervaringen hiermee zijn wel aan bod gekomen in de bijeenkomst met het kennisnetwerk van het Deltaprogramma (omgevingsscan) en binnen de deskstudie.

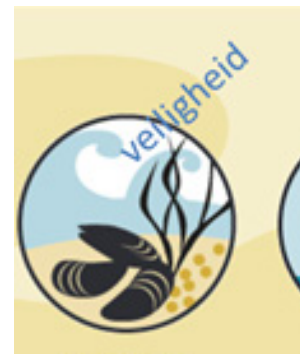

BIOBOUWERS Gebruik van organismen om sediment vast te leggen en/of golfslag te remmen

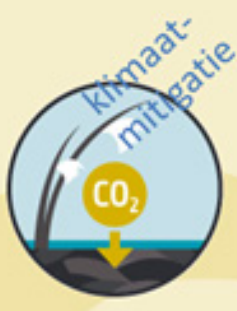

KOOLSTOF-SINK Koolstofopslag in organische stof, moerasworming

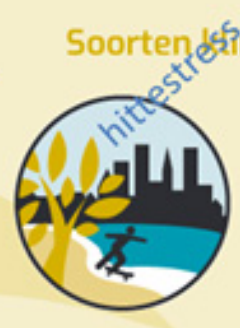

GROENE AIRCO

Temperatuurverlaging door natte natuur om de stad

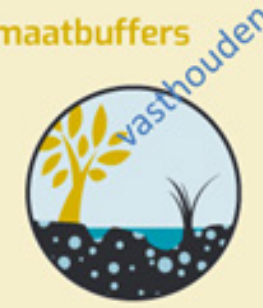

NATUURLIJKE SPONS Vasthouden water bovenloops

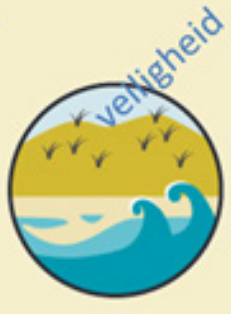

LEVENDE KUST Natuurlijke duinen met stuivend zand, zandbanken en groeiende kwelders als kustbescherming

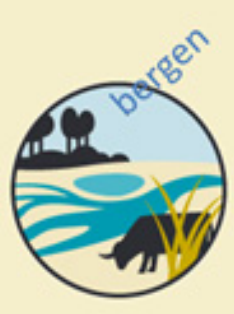

GROENBLAUWE RUIMTE Natuurliike overstromingsgebieden bergen het water bij hevige neerslag en piekafwoeren

Figuur 2.3 Verschillende typen klimaatbuffers en hun kenmerken (CNK 2019). Het type 'Groenblauwe Ruimte' gaat om zowel (piek)waterberging in (a) lagergelegen natuurgebieden in peri-urbaan gebied en $(b)$ in natuur langs de grote rivieren.

Uitspraken van de projectleiders over bijdragen van natuurlijke klimaatbuffers aan klimaatbeleid, natuurdoelen en economie zijn, waar mogelijk, geverifieerd binnen de deskstudie. De ervaringen die zij hadden met succes- en faalfactoren en koppelkansen zijn vergeleken met de uitkomsten van de omgevingsscan (hoofdstuk 6) met het doel om hier generieke conclusies uit te trekken (hoofdstuk 7 en 8 ). Projectleiders hebben de gelegenheid gekregen om de getrokken conclusies over hun project te reviewen. 
Tabel 2.2 Overzicht van de geselecteerde klimaatbuffers voor verdieping en het type klimaatbuffer waartoe ze horen. De indeling met de vinkjes $(\sqrt{ })$ volgen de indeling van de $C N K$-website. Sommige projecten zijn onder meerdere typen in te delen, aangegeven met een dubbel ster (**).

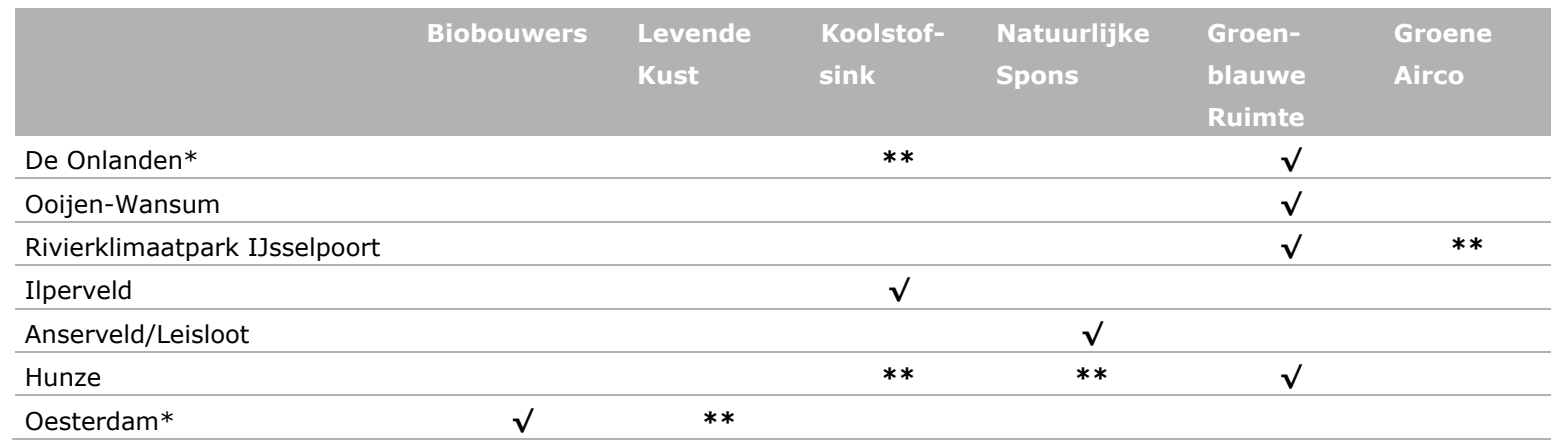

* De KB-projecten Bargerveen en Roggenplaat zijn in deze twee gesprekken ook aan bod gekomen. 


\section{CNK-programma in vogelvlucht}

\subsection{Periode 2008-2014: pilotfase}

Rond 2006 werd de term 'klimaatbuffer' voor het eerst gebruikt binnen de HIER-klimaatcampagne vanuit het besef dat de natuur mogelijkheden biedt om de gevolgen van klimaatverandering op te vangen. Een coalitie van ARK Natuurontwikkeling, LandschappenNL, Natuurmonumenten, Staatsbosbeheer, Vogelbescherming Nederland, De Waddenvereniging en Wereld Natuur Fonds (WNF) stonden aan de wieg van de eerste twintig klimaatbuffer-gebiedsprojecten (figuur 2.2).

De eerste uitvoeringsfase (2008-2014) werd gefinancierd met een stimuleringssubsidie van het toenmalige ministerie van VROM (v.a. 2010 Infrastructuur en Milieu), middelen van regionale overheden, Rijkswaterstaat en de Nationale Postcode Loterij. Daarnaast zijn er in deze periode een aantal strategische projecten (studies) uitgevoerd (tabel 3.1).

Tabel 3.1 Uitgevoerde strategische CNK-studies.

\begin{tabular}{|c|c|}
\hline Studie & Belangrijkste conclusie \\
\hline $\begin{array}{l}\text { Rijn-corridor (van Deursen } \\
\text { et al. 2013; Van Kreveld } \\
\text { 2013) }\end{array}$ & $\begin{array}{l}\text { Het project heeft op een rij gezet wat de mogelijkheden zijn om het gehele Rijnstroomgebied } \\
\text { natuurvriendelijker en klimaatbestendiger in te richten. Over de hypotheses bestaat een } \\
\text { verschil van inzicht tussen Rijkswaterstaat en de CNK. De belangrijkste patstelling gaat over } \\
\text { de vraag of het effectiever is om te investeren in sponswerking in het middelgebergte van } \\
\text { het Rijnstroomgebied of te kiezen voor alleen dijkversterking en nevengeulen aanleg in } \\
\text { Nederland zoals in het Deltaprogramma gedaan wordt. Er zijn nog geen doorbraken in deze } \\
\text { discussie (2019), een vergelijkbaar debat is later bijvoorbeeld ook gevoerd over nut en } \\
\text { noodzaak van de aanleg van de nevengeul bij Varik (During et al. 2016). Het project heeft } \\
\text { de samenwerking verbeterd tussen natuur- en milieu-organisaties, in en gericht op het } \\
\text { internationale Rijn-stroomgebied. }\end{array}$ \\
\hline $\begin{array}{l}\text { Rijnstrangen } \\
\text { (Gelderse Poort) }\end{array}$ & $\begin{array}{l}\text { Er is een strategische studie uitgevoerd naar een herinrichting van de Rijnstrangen met het } \\
\text { klimaatbufferconcept. De herinrichting is nog niet gerealiseerd (2019) omdat er onvoldoende } \\
\text { draagvlak was bij de overheid. Wel lopen er deeltrajecten voor de gebieden Kandia en } \\
\text { Klompenwaard. }\end{array}$ \\
\hline Afsluitdijk & $\begin{array}{l}\text { In } 2006 \text { is de Afsluitdijk getoetst aan de norm voor waterveiligheid en bleken er } \\
\text { verbeteringen nodig. De overheid heeft eerst ingezet op noodzakelijke renovatie } \\
\text { gecombineerd met het verhogen van de ruimtelijke en ecologische kwaliteit van de } \\
\text { Afsluitdijk. CNK heeft bijgedragen aan de dialoog over het ontwerp. In } 2009 \text { kwam } \\
\text { Nederland in een economische crisis en is gekozen voor een versoberde uitvoering van de } \\
\text { renovatie (Rijkswaterstaat } 2015 b \text { ). Er is met betrokkenheid van natuurorganisaties een } \\
\text { vismigratierivier aan het ontwerp toegevoegd (Rijkswaterstaat 2015c). Er wordt op dit } \\
\text { moment een MIRT-verkenning uitgevoerd om aanvullende vismigratiemogelijkheden te } \\
\text { realiseren bij de sluizen bij Den Helder in combinatie met habitatherstel (PAGW-maatregel } \\
\text { Wieringerhoek) (Feddes et al. 2018). Het Deltaprogramma onderzoekt wat versnelde } \\
\text { zeespiegelstijging betekent voor de pomp- en spuicapaciteit bij de herijking van de } \\
\text { voorkeursstrategie van het IJsselmeer (Remmelzwaal et al. 2019). }\end{array}$ \\
\hline
\end{tabular}




\begin{tabular}{|c|c|}
\hline Studie & Belangrijkste conclusie \\
\hline $\begin{array}{l}\text { Zoetwater Laag- } \\
\text { Nederland }\end{array}$ & $\begin{array}{l}\text { In dit strategisch project zijn de voor- en nadelen op een rij gezet van een alternatieve } \\
\text { aanvoer van zoetwater naar de veenweidegebieden en droogmakerijen in West-Nederland. } \\
\text { De hypothese was dat een alternatieve aanvoer van zoetwater vanuit o.a. het Amsterdam- } \\
\text { Rijnkanaal een zoetwater-inlaat bij Gouda overbodig maakt, waardoor er meer kansen } \\
\text { ontstaan om zoet-zoutgradiënten te herstellen langs o.a. Nieuwe-Waterweg en Haringvliet. } \\
\text { In de voorkeursstrategie van het Deltaprogramma Zoetwater (Staf Deltacommissaris 2014) } \\
\text { is uiteindelijk (nog) niet gekozen voor een permanent oostelijke aanvoer (POA), maar de } \\
\text { POA bleef wel één van de mogelijke alternatieven voor de opvolger van de kleinschalige } \\
\text { wateraanvoer (KWA). Tussen } 2015 \text { en } 2018 \text { is een "Joint Fact Finding-proces" gestart door } \\
\text { het Deltaprogramma om de effectiviteit van een POA voor West-Nederland in beeld te } \\
\text { brengen (INFRAM 2017). Hieraan hebben WNF en Natuurmonumenten deelgenomen. Het } \\
\text { proces wordt gecoördineerd door de provincie Zuid-Holland. Er zijn deelonderzoeken gedaan } \\
\text { door Deltares, Hydrologic en WUR (Hydrologic 2018; van der Kaaij and Huismans } 2016 \text {; } \\
\text { Vellinga et al. 2014). Binnen LIFE IP Deltanatuur doet WNF onderzoek wat het Kierbesluit, } \\
\text { en de eventuele uitbreiding hiervan, kan betekenen voor natuurwaarden in het Haringvliet } \\
\text { en Nieuwe Waterweg (Veraart and Klostermann 2019). De droge zomers van } 2018 \text { en } 2019 \\
\text { hebben de POA weer wat hoger op de agenda van het Deltaprogramma gezet. }\end{array}$ \\
\hline Oostdijk Texel & $\begin{array}{l}\text { Dit was van origine een strategisch project, maar is na } 2017 \text { een gebiedsproject geworden } \\
\text { en omgedoopt tot Prins Hendrikzanddijk (hoofdstuk 5.5). }\end{array}$ \\
\hline
\end{tabular}

\subsection{Periode 2015-2022: mainstream maken}

In 2015 besloot de CNK het programma klimaatbuffers voort te zetten, ondanks gebrek aan financiële middelen. In 2017 is de doorstart geformaliseerd en is de coalitie uitgebreid met de Natuur- en Milieufederaties. Het programma wordt sinds 2017 uitgevoerd met financiële steun van het Europese programma LIFE IP Deltanatuur (looptijd tot 2022) en het ministerie van Landbouw, Natuur en Voedselkwaliteit (LNV). Het hoofddoel in deze tweede fase is dat klimaatbuffers vanzelfsprekend geworden zijn in 2022. De coalitie wil met name bevorderen dat werken met 'nature based solutions' (natuurlijke klimaatbuffers) de voorkeursaanpak wordt van overheden en private partijen bij ingrepen gericht op waterveiligheid, watervoorziening en klimaatadaptatie.

Figuur 3.1 toont de natuurlijke klimaatbuffers die tot op heden gerealiseerd of in uitvoering zijn. In vergelijking met figuur 2.2 staan op deze kaart ook gebiedsprojecten die na 2014 zijn opgestart en ook projecten waarbij de CNK niet de eerste initiator was (ook voor 2012 zijn er natuurlijke klimaatbuffers geweest waarbij provincie of waterschap eerste opdrachtgever was). De status 'gereed' resp. 'in uitvoering' is beoordeeld rond de jaarwisseling 2018-2019. 'In uitvoering' betekent dat er een formele start is gemaakt met het initiatief door minimaal één partner. Projecten kunnen van meerdere typen klimaatbuffers zijn. Gekozen is voor inkleuring voor het type dat het project domineert. 


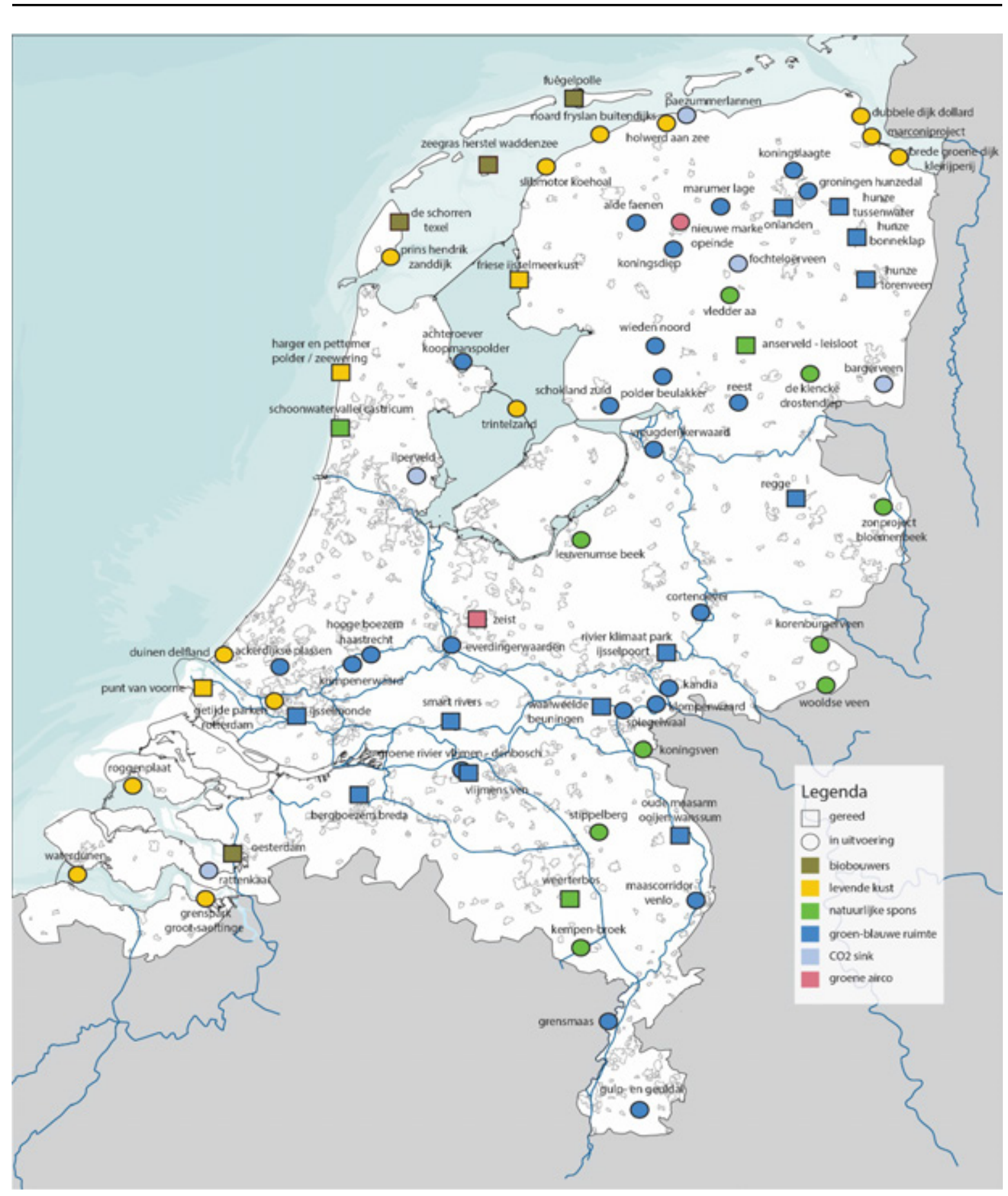

Figuur 3.1 Kaart waarop ook natuurlijke klimaatbuffers op staan die buiten de CNK om en/of na 2014 van start zijn gegaan. 


\subsection{Belangrijkste conclusies uit voorgaande evaluaties}

Het programma is meerdere malen geëvalueerd en de uitkomsten hiervan zijn in deze paragraaf samengevat. Iedere evaluatie had zijn eigen criteria, in dit overzicht zijn de conclusies gepresenteerd volgens de criteria van de tussentijdse zelfevaluatie van de CNK (2012). De tabellen zijn opgesteld op basis van de samenvattingen van de rapporten.

Tabel 3.2 Natuurlijke klimaatbuffers: kennis en kansen (CNK 2012).

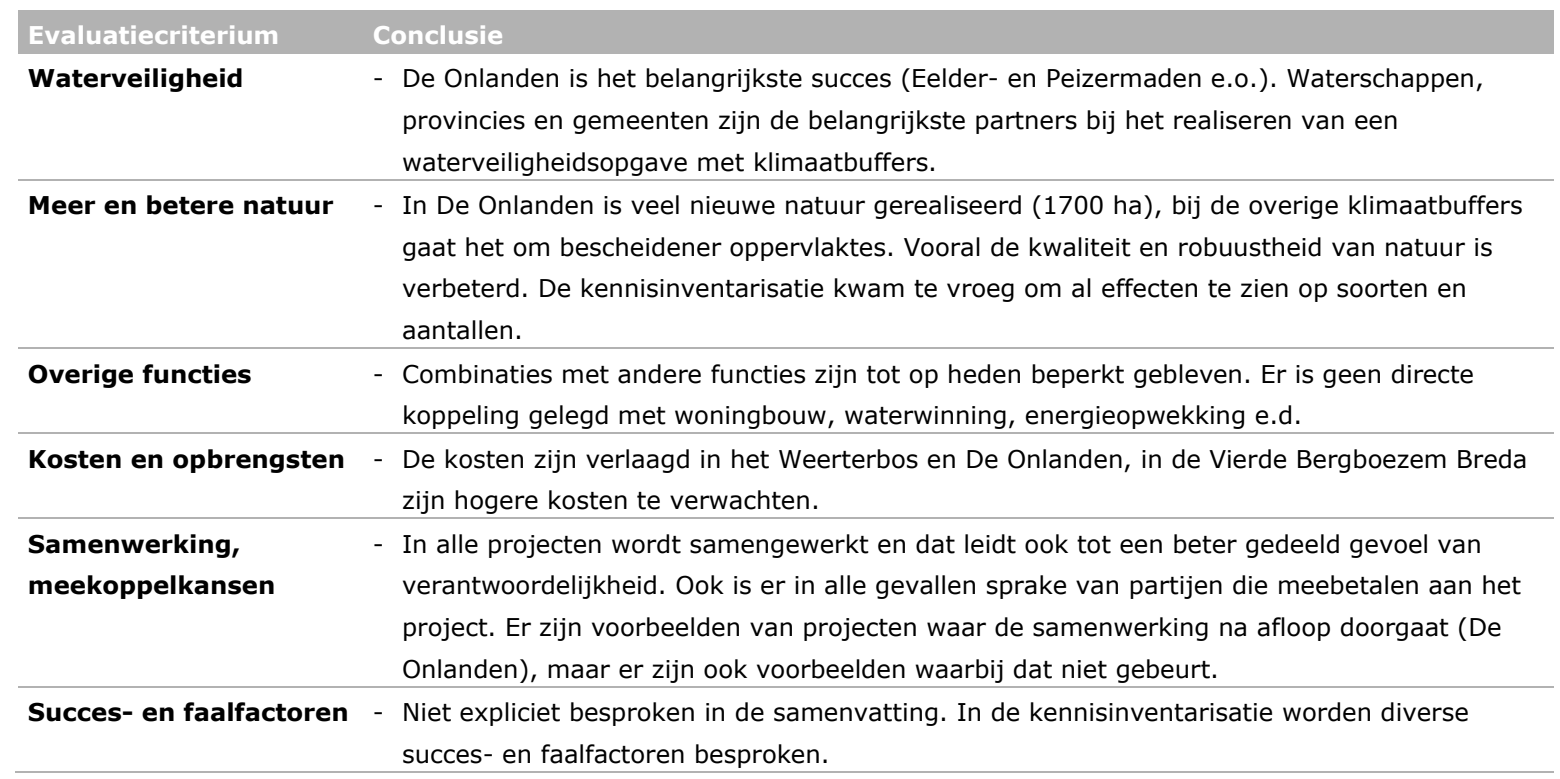

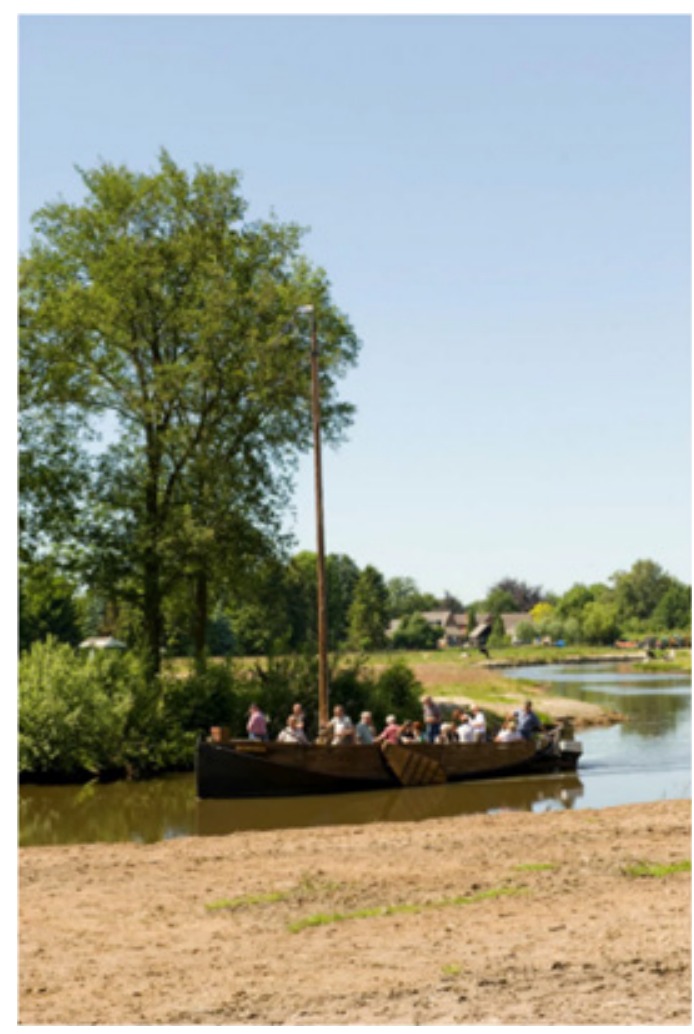

Opening Regge, Veldkamp en Dinkelpad (2009, foto: Marjolein Sterk, WUR). 
Tabel 3.3 De natuur als partner bij klimaatadaptatie (Smit et al. 2014).

\begin{tabular}{|c|c|}
\hline Evaluatiecriterium & Conclusie \\
\hline Waterveiligheid & $\begin{array}{l}\text { - In projecten met een urgente waterveiligheidsopgave wordt vaak gekozen voor traditionele } \\
\text { oplossingen, zoals dijkverzwaring. Voor natuurinclusieve opties wordt pas gekozen als een } \\
\text { conventionele oplossing niet voldoet, bijvoorbeeld omdat deze te duur is of te veel } \\
\text { weerstand oproept. Het natuurinclusieve alternatief moet dan wel aan hoge en te bewijzen } \\
\text { waterveiligheidseisen voldoen. Dit creëert een klassiek innovatiedilemma, want zonder } \\
\text { (geëvalueerde) praktijktoepassingen kan dat bewijs niet worden geleverd. Daarom is er } \\
\text { behoefte aan goed gemonitorde experimenten en pilots om dit dilemma te doorbreken. }\end{array}$ \\
\hline Meer en betere natuur & - Niet besproken in samenvatting. \\
\hline $\begin{array}{l}\text { Kosten, opbrengsten } \\
\text { en financiering }\end{array}$ & $\begin{array}{l}\text { - In klimaatbufferprojecten spelen veel verschillende ecosysteemdiensten een rol, maar deze } \\
\text { diensten worden lang niet altijd systematisch in kaart gebracht. } \\
\text { - Innovatieve financieringsmethoden en kostendoorberekening van ecosysteemdiensten } \\
\text { kunnen integrale oplossingen voor water- en natuurvraagstukken dichterbij brengen. } \\
\text { - Gebieden met laag renderend bedrijfsleven zijn kansrijker voor herinrichting met het } \\
\text { klimaatbuffer-concept. }\end{array}$ \\
\hline $\begin{array}{l}\text { Samenwerking, } \\
\text { meekoppelkansen }\end{array}$ & - Niet expliciet besproken in samenvatting. \\
\hline Succes- en faalfactoren & $\begin{array}{l}\text { - Betrokkenheid, vertrouwen en centrale regie zijn cruciale succes-/faalfactoren. } \\
\text { - Wetgeving, vooral op het gebied van waterveiligheid en natuurbescherming, kan een } \\
\text { stimulans zijn om gebiedsontwikkeling op een integrale wijze aan te pakken, voor } \\
\text { waterkwaliteit geldt dit minder. }\end{array}$ \\
\hline
\end{tabular}

Tabel 3.4 Besparingspotentieel 'Bouwen met natuur' (Sterk Consulting 2014).

\begin{tabular}{|c|c|}
\hline Evaluatiecriterium & Conclusie \\
\hline Waterveiligheid & $\begin{array}{l}\text { - Voor het dossier van waterveiligheid zijn op projectniveau door inzet van natuurlijke } \\
\text { vooroevers bij bijvoorbeeld Markermeer, Noordwaard en Oesterdam forse besparingen } \\
\text { aangetoond (mediaan van ca. } 1.750 \text { euro CW per strekkende meter). }\end{array}$ \\
\hline Meer en betere natuur & - Dit was geen evaluatiecriterium. \\
\hline $\begin{array}{l}\text { Kosten, opbrengsten } \\
\text { en financiering }\end{array}$ & $\begin{array}{l}\text { - In veel gevallen zijn bij natuurlijke oplossingsrichtingen voor realisatie van waterveiligheid } \\
\text { kostenbesparingen mogelijk, maar de grootte ervan is sterk locatie specifiek. } \\
\text { - Er is weinig kwantitatieve informatie beschikbaar over de vraag hoe het realiseren van } \\
\text { waterveiligheidsdoelen met een 'bouwen met natuur'-alternatief zich in financiële zin } \\
\text { verhoudt tot het realiseren van deze doelen met een traditioneel alternatief }\end{array}$ \\
\hline $\begin{array}{l}\text { Samenwerking, } \\
\text { meekoppelkansen, }\end{array}$ & $\begin{array}{l}\text { - Door toepassing van natuurlijke processen bij waterveiligheidsopgaven kunnen } \\
\text { besparingsmogelijkheden toenemen wanneer er meegekoppeld wordt met opgaven in } \\
\text { regionale watersystemen (waterkwaliteit, zoetwatervoorziening). }\end{array}$ \\
\hline
\end{tabular}


Tabel 3.5 Water en natur: een mooi koppel! (Van Hattum et al. 2014).

\begin{tabular}{|c|c|}
\hline Evaluatiecriterium & Conclusie \\
\hline Waterveiligheid & $\begin{array}{l}\text { - Ook bij de waterveiligheidsopgave zijn er veel voorbeelden waaruit blijkt dat ecodynamische } \\
\text { ontwerpen een duurzaam alternatief kunnen zijn voor traditionele dijkversterking. Toch } \\
\text { behoort meekoppelen van waterveiligheid en natuur nog lang niet tot de standaard } \\
\text { werkwijze. }\end{array}$ \\
\hline Meer en betere natuur & $\begin{array}{l}\text { - Het is van belang om in de uitvoeringsfase van het Deltaprogramma het aspect 'ruimtelijke } \\
\text { kwaliteit', waaronder natuur, te betrekken en te borgen als één van de ambities. }\end{array}$ \\
\hline $\begin{array}{l}\text { Kosten, opbrengsten } \\
\text { en financiering }\end{array}$ & $\begin{array}{l}\text { - Door forse bezuinigingen op het natuurdossier en de bevriezing van de ILG-uitgaven } \\
\text { (Investeringsbudget Landelijk Gebied) voor de Ecologische Hoofdstructuur is de realisatie } \\
\text { van integrale water- en natuurprojecten op regionaal niveau gestagneerd. } \\
\text { - Vrijwel alle geïnterviewde partijen noemen een stimuleringsfonds als een middel om } \\
\text { meekoppelprojecten sneller van de grond te krijgen. }\end{array}$ \\
\hline $\begin{array}{l}\text { Samenwerking, } \\
\text { meekoppelkansen }\end{array}$ & $\begin{array}{l}\text { - De programma's Natuurlijke Klimaatbuffers, Building with Nature, Ruimte voor de Rivier en } \\
\text { het Corporate Innovatieprogramma van Rijkswaterstaat hebben veel kennis en ervaring } \\
\text { opgeleverd over slimme combinaties van water en natuur. } \\
\text { - In de regionale wateren vindt meekoppelen van water en natuur al veel plaats, zoals bij de } \\
\text { uitvoering van projecten voor de Kaderrichtlijn Water (KRW), het Nationaal Bestuursakkoord } \\
\text { Water en het realiseren van het Natuurnetwerk Nederland. Vaak zijn provincies en } \\
\text { waterschappen de regisseurs, maar ook natuurorganisaties kunnen het initiatief nemen. } \\
\text { - Aanbeveling: een meekoppeltoets als een standaard en verplicht onderdeel in de } \\
\text { voorbereiding van uitvoeringsprojecten (bijvoorbeeld projecten uit het Meerjarenprogramma } \\
\text { Infrastructuur, Ruimte en Transport). } \\
\text { - Integrale oplossingen voor water- en natuuropgaven vragen om experimenteerruimte en } \\
\text { bieden kansen voor groene innovaties. Dit vraagt intensievere samenwerking tussen } \\
\text { overheid, bedrijfsleven, kennisinstellingen én natuurorganisaties, de zogenaamde 'Gouden } \\
\text { Vierhoek', bijvoorbeeld gestimuleerd vanuit de Topsector Water. } \\
\text { - Er zijn met de uitvoering van het Deltaprogramma, de nieuwe KRW- } \\
\text { stroomgebiedsbeheerplannen en het Natuurpact de komende jaren veel wateropgaven en } \\
\text { natuurdoelen te realiseren met meekoppelkansen. } \\
\text { - Meekoppelen van water- en natuurdoelen wordt vanzelfsprekend wanneer hieraan een } \\
\text { integrale gebiedsvisie of gebiedsagenda ten grondslag ligt. }\end{array}$ \\
\hline Succes- en faalfactoren & $\begin{array}{l}\text { - Verkokering van beleidsvelden staat een integrale aanpak in de weg. Procedures en } \\
\text { spelregels zijn sterk gescheiden en verschillend bij water- en natuurbeleid. } \\
\text { - Het is bijna onvermijdelijk dat er gedurende de uitvoering van grote complexe } \\
\text { meekoppelprojecten wisselingen optreden in de samenstelling van bestuurders, ambtenaren } \\
\text { en andere vertegenwoordigers. } \\
\text { - Het Hoogwaterbeschermingsprogramma stuurt sterk op sober en doelmatig en hanteert een } \\
\text { stringente planning. }\end{array}$ \\
\hline
\end{tabular}




\section{$4 \quad$ Verdieping met geselecteerde klimaatbuffers}

\section{$4.1 \quad$ Introductie}

In dit hoofdstuk staan de ervaringen van projectleiders uit zeven geselecteerde klimaatbuffers centraal. Vooraf is gekeken welke verwachtingen zijn benoemd door de CNK in twee zelfevaluaties (CNK 2012; CNK 2014) en in de gesprekken is besproken welke ontwikkelingen hierover zijn te melden.

\subsection{Onlanden}

Inleiding

\begin{abstract}
Klimaatbuffer De Onlanden was voorheen een laaggelegen landbouwgebied dat al wel was begrensd als toekomstig onderdeel van de Ecologische Hoofdstructuur (EHS), heden het Natuurnetwerk Nederland (NNN). Steeds grotere problemen met bodemdaling en overtollig water maakten ingrijpen eind jaren negentig urgent. In 1998 liepen de stad Groningen en de provincie deels onder water. Deze gebeurtenis was de directe aanleiding om dit gebied van 2500 hectare in te richten als waterbergings- en natuurgebied.
\end{abstract}

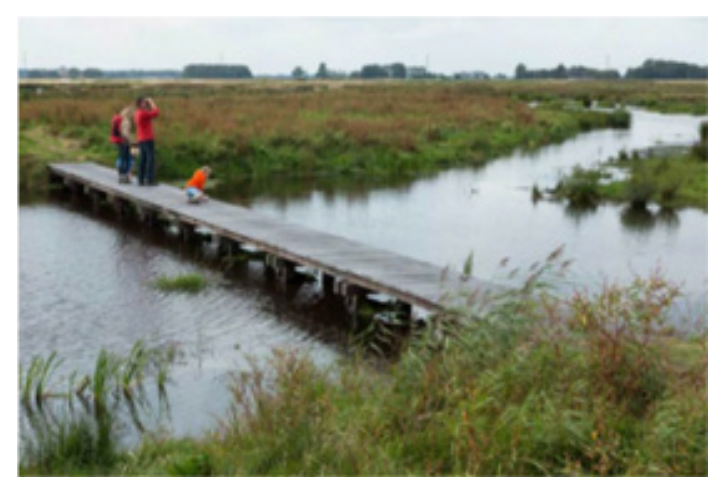

Foto: Natuurmonumenten.

\section{Klimaatadaptatie - Waterberging}

Op dit moment wordt de bergingscapaciteit met modelberekeningen geschat op ruim 5 miljoen $\mathrm{m}^{3}$ (Hazelhorst 2014) tot maximaal 10 miljoen $\mathrm{m}^{3}$ (Waterschap noorderzijlvest 2019) onder de meest gunstige meteorologische condities. In de kosteneffectiviteitsberekening is gewerkt met de inschatting van Hazelhorst, mede omdat de projectleider ook aangeeft dat de praktijk nog moet uitwijzen hoeveel waterberging gerealiseerd kan worden met een meestromende waterberging. Met een voorziene waterbergingscapaciteit van 5 miljoen $\mathrm{m}^{3}$ voorziet De Onlanden in meer dan $20 \%$ van de totale waterbergingsopgave die het waterschap Noorderzijlvest in 2014 wilde realiseren. Daarnaast is het waterbeheer voor 3500 hectare omliggend landbouwgebied verbeterd.

Het waterschap wil waterberging en natuurontwikkeling op soortgelijke wijze combineren in andere projecten zoals Zuidelijk Westerkwartier. Ook zijn er nieuwe plannen voor extra waterberging in de Onlanden bij de Eelder- en Peizermaden (Waterschap noorderzijlvest 2019). De wijze waarop deze berging wordt gerealiseerd is momenteel onderdeel van een MER-studie.

\section{Klimaatmitigatie}

De Onlanden ligt op veengrond. Door de vernatting zijn de emissies van broeikasgassen sterk gereduceerd zodat het gebied netto broeikasgassen vastlegt. Op de voormalige landbouwgronden wordt de vastlegging van $\mathrm{CO} 2$ mogelijk deels tenietgedaan omdat deze door nutriëntenrijkdom bij vernatting ook extra lachgas $\left(\mathrm{N}_{2} \mathrm{O}\right)$ uitstoten. In de moerasgebieden komt bij vernatting mogelijk extra methaan $\left(\mathrm{CH}_{4}\right)$ vrij, ook dat is een broeikasgas. Er zijn voor De Onlanden nog geen uitspraken mogelijk over de $\mathrm{CO}_{2}$-eq-vastleggingscapaciteit gebaseerd op trendanalyse van meerjarige 
meetreeksen ${ }^{6}$. In Hoofdstuk 5.4 is voor de Onlanden een hypothese opgesteld over de mogelijke vastlegging van broeikasgassen.

\section{Natuurrendement}

Tabel 4.1 geeft aan hoe de natuur zich ontwikkelt. Omdat tijdens het planproces vragen zijn gesteld over het risico van muggenplagen is ook dit risico gemonitord. Alleen over broedvogels en de otter wordt jaarlijks gerapporteerd, beide zijn in aantal toegenomen en de broedvogels ook in diversiteit. $\mathrm{Er}$ verbleven in 2018 minstens tien volwassen otters (van Boekel et al. 2019). Op waarneming.nl is een breed overzicht te vinden van ook andere (zeldzame) flora en fauna die na realisatie van De Onlanden is gezien. Daaruit valt af te leiden dat de biodiversiteit sterk is toegenomen, maar er zijn geen analyses gevonden die de toename kwantificeren.

Tabel 4.1 Synoptisch overzicht van waargenomen natuureffecten in klimaatbuffer De Onlanden na 2014 n.a.v. de verwachtingen/doelen (voor 2014).

\begin{tabular}{|c|c|}
\hline Landnatuur & Waternatuur \\
\hline \multirow[t]{2}{*}{$\begin{array}{l}\text { De werkgroep monitoring rapporteert jaarlijks over } \\
\text { broedvogels en otters. De broedvogels nemen spectaculair } \\
\text { toe in aantal en diversiteit (van Boekel et al. 2019). }\end{array}$} & $\begin{array}{l}\text { De oppervlakte moerasnatuur is gegroeid, er zijn geen } \\
\text { gegevens gevonden over de kwaliteit van de gerealiseerde } \\
\text { aquatische natuur. }\end{array}$ \\
\hline & $\begin{array}{l}\text { Er heeft monitoring plaatsgevonden om het risico in te } \\
\text { schatten van muggenplagen en maatregelen om overlast te } \\
\text { voorkomen (Lototskaya et al. 2011). }\end{array}$ \\
\hline
\end{tabular}

\section{Economie - kosteneffectiviteit}

Waterschap Noorderzijlvest heeft een evaluatie laten uitvoeren naar het doelbereik, de kosteneffectiviteit van de investering en de kosten voor beheer en onderhoud (Schoevaart et al. 2014). Dit is in deze studie van Schoevaart vergeleken met (a) vergelijkbare waterbergingsprojecten in Nederland die gecombineerd zijn met natuurontwikkeling en (b) noodwaterberging zonder natuurontwikkeling. In een andere studie is ook het alternatief voor waterberging met natuurontwikkeling vergeleken een kadeverhoging voor een groot gebied (Sterk Consulting 2014).

In tabel 4.2 zijn de inzichten van deze studies geïntegreerd. De totale realisatiekosten van De Onlanden bedroegen in totaal 42,9 miljoen euro. Daarnaast zijn de meeste kosten gemaakt met het verwerven van de gronden (Lievense Ingenieurs 2018a). Waterschap Noorderzijlvest en provincie Drenthe hebben beide $€ 17,3$ miljoen bijgedragen. De resterende $€ 8,3$ miljoen is bijgedragen door gemeenten, Europa, de regio en terreinbeheerders. De financiering door de provincie Drenthe bestond uit subsidies voor het Nationaal Natuur Netwerk.

\footnotetext{
${ }^{6}$ Er wordt experimenteel onderzoek gedaan naar broeikasgasemissies in nabijgelegen gebieden door de Radboud Universiteit.
} 
Tabel 4.2 Economische kengetallen De Onlanden (Lievense Ingenieurs 2018a; Schoevaart et al. 2014; Sterk Consulting 2014). Er zijn marges gegeven omdat verschillende bronnen tot een verschillend bedrag komen voor de definitieve kosten. Het zijn dus geen ramingen van kosten.

\begin{tabular}{|c|c|c|c|}
\hline & Berging + natuur & Kadeverhoging & Noodwaterberging \\
\hline $\begin{array}{l}\text { Kosten waterberging ( } \mathrm{mln} \text {. } \\
\text { euro) }\end{array}$ & $16-20$ & 116 & $\begin{array}{l}\text { De investering is lager dan } \\
\text { voor een KB. Bij een } \\
\text { noodwaterberging kunnen er } \\
\text { wel extra kosten zijn } \\
\text { vanwege } \\
\text { natschadevergoeding aan } \\
\text { boeren. }\end{array}$ \\
\hline $\begin{array}{l}\text { Kosten grondwerving en } \\
\text { recreatie (Lievense } \\
\text { Ingenieurs 2018a) }\end{array}$ & $23-27$ & n.v.t. & \\
\hline Berging (miljoen $\mathrm{m}^{3}$ ) & $5,6-10$ & & \\
\hline Beheer en onderhoud & Complexer & Onbekend & Goedkoper dan KB \\
\hline Baten & $\begin{array}{l}\text { Waterkwaliteit, reductie } \\
\text { wateroverlast, CO2-reductie, } \\
\text { recreatie, natuurkwaliteit }\end{array}$ & & Reductie wateroverlast \\
\hline
\end{tabular}

\section{Succesfactoren}

- De wateroverlast in Groningen door extreem weer heeft geleid tot draagvlak om maatregelen te nemen;

- Het plan-alternatief (kadeverhoging) was ongeveer drie keer zo duur als het KB-concept (alle kosten meegerekend);

- De natuurbaten waren een reden voor de provincie Drenthe om voor waterberging gecombineerd met natuurontwikkeling te kiezen en niet voor een kale noodwaterberging;

- Er was al sprake van een landinrichtingstraject waarbij kon worden aangesloten en dat door de synergie met waterberging en natuur in een ongekende versnelling kwam;

- Terugkijkend is het enthousiasme bij alle partijen en publieke opinie nóg groter dan in de beginfase.

Faalfactoren

- De kosteneffectiviteit werd door de waterbeheerder alleen uitgedrukt in $€ \mathrm{~m}^{-3}$, terwijl er ook baten zijn voor natuur en recreatie van deze investering. Wanneer dit kengetal bij toekomstige projecten wordt gebruikt kan (onterecht) geconcludeerd worden dat noodwaterberging kostenefficiënter is;

- Beheer en onderhoud van waterberging in combinatie met natuurontwikkeling is lastiger contractueel te regelen. Dat kan een faalfactor zijn voor toekomstige vergelijkbare projecten. Vertrouwen bij dit soort processen is daarom zeer belangrijk.

\subsection{Ooijen-Wansum}

De Oude Maasarm is ingericht als hoogwaterbergingsgebied (375 hectare), waarvan 80 hectare in bezit van Staatsbosbeheer. Deze 80 hectare is ingericht als natuurlijke klimaatbuffer (CNK 2012). Dankzij deze inrichting kan de Oude Maasarm weer volstromen bij hoogwater op de Maas, leidend tot lagere waterstanden op de rivier. Tevens was de maatregel een KRW-maatregel (cofinanciering). De verwachting vooraf was dat de klimaatbuffer, samen met de twee te graven hoogwatergeulen ${ }^{8}$ in het uiterwaardengebied, zal leiden tot een piekverlaging van circa 35 centimeter bij hoogwater en dat de Oude Maasarm eens per 3-6 jaar mee zal stromen met de Maas (Projectbureau Ooijen-Wanssum and Aannemerscombinatie Mooder Maas 2019). De omliggende afwatering is intact gebleven, er is alleen

\footnotetext{
7 In vergelijkbare waterbergingsprojecten die gecombineerd zijn met natuurontwikkeling zijn kostprijzen gerapporteerd die variëren tussen $0.45 € \mathrm{~m}^{-3}$ in de Hunze (Onner \& Oostpolder) en $4.44 € \mathrm{~m}^{-3}$ in HoWaBo (Schoevaart et al. 2014).

8 De hoogwatergeul Wanssum is gereedgekomen in november 2018, onderdeel van het programma Ruimte voor de Rivier.
} 
een peilverschil gerealiseerd binnen de natuurstrook van de klimaatbuffer. De drainerende werking is hierdoor verminderd, wat verdroging in de zomer voor de omliggende landbouwgronden kan verminderen. Door de ontwikkeling van moerasvegetatie en struweel aan de randen van de geul, zal in bescheiden mate $\mathrm{CO}_{2}$ worden vastgelegd. Na realisatie van de integrale gebiedsontwikkeling is het risico op waterschade in de regio en stroomopwarts verminderd door de verlaging van de hoogwaterpiek in de Maas. Tijdens hittegolven kan het waterrijke projectgebied wellicht een uitweg bieden uit de hete stedelijke omgeving (dagrecreatie).

Klimaat

- Pas nadat de hele gebiedsontwikkeling is afgerond (medio 2020) en er zich een situatie met hoogwater heeft voorgedaan, wordt duidelijk hoe effectief de maatregel daadwerkelijk is (in centimeter waterpeilverlaging);

- Er is geen informatie gevonden over de gerealiseerde klimaatmitigatiepotenties.

Natuur

- Het gebied is nu als procesnatuur ingericht inclusief natuurlijke begrazing en cyclisch onderhoud. Met het KB-project worden betere verbindingen gerealiseerd met omliggend natuurgebied;

- Monitoring was geen onderdeel van de opdracht. Misschien komt hier aandacht voor als de gebiedsontwikkeling is afgerond vanuit Rijkswaterstaat of het waterschap;

- De natuurwaarden worden gemonitord aan de hand van waarnemingen door de beheerders en vrijwilligers.

\section{Economie}

- Er is actief beheer nodig om het gebied open te houden voor een goede doorstroming bij hoogwater in de Maas. Hiervoor past Staatsbosbeheer begrazing toe, uitbesteed aan een lokale agrarische natuurvereniging. De beheerkosten zijn voor Staatsbosbeheer zeer beperkt;

- Het wandelnetwerk is uitgebreid (verdubbeld), met wandelmogelijkheden in de lengterichting van de geul en struinnatuur. Een nieuwe uitkijkpost biedt een goed overzicht over het gebied. Het bestaande fietspad is aantrekkelijker geworden. Bezoekers (dagjesmensen en lokale bewoners) waarderen de ervaring van ruimte (interview).

\section{Succesfactoren}

- Wateroverlast door hoogwatergebeurtenissen hebben de uitvoering vergemakkelijkt, de urgentie werd gevoeld;

- Omdat fase 1 van de klimaatbuffer reeds begin 2013 is opgeleverd (alle gronden voor het projectgebied waren al van Staatsbosbeheer), kan dit project een katalyserende werking hebben voor de overige onderdelen van de integrale gebiedsontwikkeling.

\subsection{Rivierklimaatpark IJsselpoort}

Rivierklimaatpark IJsselpoort is een visieproject voor de gehele uiterwaarden tussen IJsselkop en Giesbeek (de buitendijkse gronden). De visie is opgesteld door negen overheden en onderdeel geworden van het Meerjarenprogramma Infrastructuur, Ruimte en Transport (MIRT) van de Rijksoverheid. In het gebied liggen kansen voor het integraal realiseren van rivierdoelen voor waterveiligheid, KRW, scheepvaart, natuur, energie, economie, klimaat e.d. De visie van het Rivierklimaatpark is geland in een intergemeentelijke structuurvisie, waarvoor nu het voorkeursalternatief klaar is, en die naar verwachting rond kerst 2019 ter vaststelling ligt bij de gemeenteraden. Maatregelen die zijn voorgesteld in de visie zijn kadeverlaging, aanleggen van een geul voor zowel KRW-doelen als waterstandsverlaging bij hoge afvoer, scheepvaartmaatregelen, ontstenen van oevers, aanleggen faunapassages, natuurinclusieve landbouw, ontwikkeling bedrijvigheid, aanpassen verkeersstructuur, energieopslag en zo verder.

Eén inrichtingsproject is al uitgevoerd in het gebied, op Natura 2000-gronden van Natuurmonumenten (afgerond zomer 2019). De natuurdoelen voor de inrichting zijn ingevuld door bijvoorbeeld het omvormen van landbouwgrond naar natuur en een toename van glanshaverhooilanden en stroomdalgraslanden. Hierdoor kan water langer vastgehouden worden. Ook zijn struinpaden aangelegd. Rivierverruimingsmaatregelen en dergelijke waren in deze fase door Rijkswaterstaat niet toegestaan. 


\section{Klimaatadaptatie}

- De aircofunctie van het Rivierklimaatpark (fase I) is niet onderbouwd door de initiatiefnemer. Wel komen mensen uit de stad verkoeling zoeken in dit gebied.

- Voor extreme natte periodes is het KB-project Rivierklimaatpark toekomstbestendig want de kades kunnen nog verder verlaagd worden. Met het oog op drogere periodes in de toekomst kunnen ook meer laagtes gecreëerd worden waar het water kan blijven staan. Op de website wordt ingegaan op zowel de functie van het project voor wateroverlast als watertekort, ook in de rivier zelf: "De rivier verruimende maatregelen, zoals de kadeverlagingen, helpen om het uitschuren van de vaargeul en daarmee ook de verdroging van de uiterwaarden tegen te gaan." (Projectteam Rivierklimaatpark IJsselpoort 2019).

\section{Natuur}

- De binnendijkse en buitendijkse laterale verbindingen worden verbeterd, daar wordt in deze twee projecten ervaring en kennis mee opgedaan.

- De inrichting is nog niet afgerond dus er is nog niet te zeggen wat de effecten voor de natuur precies zijn. Op de hogere oeverwallen is het beheer twee jaar geleden al ingegaan en hebben terreinbeheerder al positieve effecten op de natuur waargenomen.

- LIFE-doelen voor Natura 2000-doelen worden gemonitord.

\section{Economie}

- De energiediscussie is nu veel groter dan voorheen, misschien kan een koppeling gemaakt worden met een 'energiepark'. Een eerder idee over windmolens in de uiterwaarden is gestrand omdat dit om een discussie vraagt op een groter schaalniveau.

- Interessant recreatiegebied met bijbehorende economische bedrijvigheid.

\section{Succesfactoren}

- De beelden van de Natuur Ambitie Grote Wateren (Ministerie van Economische Zaken 2014) hebben bij dit project geholpen om de noodzaak van herstel van binnen- en buitendijkse verbindingen op de kaart te houden.

- Naar de burger zijn vooral het 'park'-idee en de recreatiemogelijkheden in het verleden gecommuniceerd. Voor de toekomst denkt het projectteam na over een bredere boodschap: rivierklimaatpark, dat zijn drie woorden - rivier, klimaat en park. Hierbij wil men het woord 'klimaat' een andere betekenis geven: toepassing van vormen van duurzame energie met natuurontwikkeling.

- Rijkswaterstaat heeft steeds meer kennis ter beschikking, werkt proactief mee en is meer innovatief. Zelfs beleidsregels kunnen aangepast worden. Rijkswaterstaat helpt ook met belangen inventariseren.

\section{Faalfactoren}

- De klimaatbuffer-aanpak (meer dynamiek) en Natura 2000 kunnen in tegenspraak zijn in dit soort projecten.

- Klimaatvraagstukken voor scheepvaart worden niet altijd opgelost met dit type klimaatbuffers. Wat kunnen we doen met natuurlijke oplossingen en waar zijn toch technische oplossingen nodig om natuur en scheepvaart te combineren? Daar is kennisontwikkeling nodig. Wel is net als bij Integraal Riviermanagement scheepvaart nu opgenomen in de intergemeentelijke structuurvisie.

- Discussie en communicatie vanuit het projectteam over de mogelijke aanleg van windmolens en keuzes in het beheer (bijvoorbeeld nietsdoen bij droogte en laagwater), leidt soms tot (tijdelijk) minder draagvlak bij recreanten en omwonenden. 
De wijk IJsselmonde ( 105.000 hectare) is te omschrijven als een stadseiland aan de zuidrand van Rotterdam, omgrensd door de Oude Maas en een aantal kleinere wateren. Er wonen 423.000 mensen. Het KB-project (600 hectare) ligt aan de grens met stedelijk gebied. Er zijn natuurvriendelijke oevers (KRW) gerealiseerd langs het riviertje Koedood. In de betreffende polder (Zuidpolder) is flexibel peilbeheer ingevoerd om water langer vast te houden en neerslag te bergen.

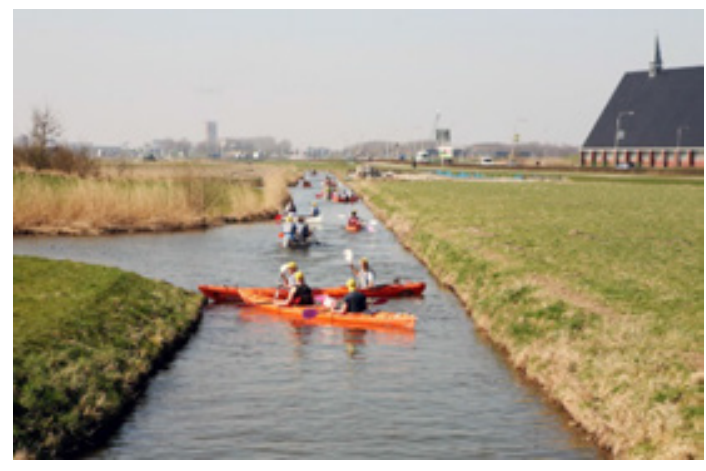

Foto: Gemeente Rotterdam.

In het project zijn de Oude Maas, Zuidpolder (inclusief Gaaskensplas en Koedoodplas) en de Blauwe Verbinding nu aan elkaar gekoppeld met enkele duikers. De verwachting is uitgesproken dat het gebied verkoeling kan bieden voor de bewoners van de omliggende gebieden (CNK 2012). De bedoeling was om deze kleine ingrepen later op te schalen zodat het gebied daadwerkelijk robuuster wordt voor toenemende verzilting en klimaatverandering; het laatste is niet gelukt.

\section{Klimaatadaptatie}

Flexibel peilbeheer maakt het gebied (op de korte termijn) klimaatbestendiger, onder andere doordat regenwater langer wordt vastgehouden. Helaas gaat het maar om 20 centimeter peilfluctuatie (twee flinke regenbuien kunnen extra opgevangen worden). Op de langere termijn is dat niet voldoende.

Het water- en natuurbeheer in klimaatbuffer IJsselmonde is nog niet aangepast op verziltingsrisico's bij lage afvoer van de Oude Maas in droge tijden (zoals de zomer van 2018). Dat komt omdat onvoldoende water binnendijks kan worden opgeslagen. Er wordt momenteel in het winterhalfjaar net zoveel regenwater uitgeslagen als er in het zomerhalfjaar wordt ingelaten. Bij verzilting van de Oude Maas wordt het inlaten van rivierwater een probleem. Dit probleem wordt in de toekomst groter en kan alleen opgelost worden met een grotere klimaatbuffer die minder afhankelijk is van de inlaat.

\section{Natuur}

Flexibel peilbeheer en het herstel van de verbindingen zijn gunstig voor de natuur. Zo is tijdens een visinventarisatie een toename van het aantal soorten vastgelegd. Voor de lange termijn zijn vanuit natuur nog extra maatregelen nodig maar niemand ziet nu de noodzaak, terwijl het vasthouden van water en peilfluctuaties volgens het regenwatermodel cruciaal zijn voor ecologische ontwikkeling.

Er waren waterkwaliteitsproblemen (zuurstofloosheid) in de Gaatkens- en Koedoodplas door onder andere nutriëntenlekkage en een te vlak bodemprofiel (dat zorgde voor een lage biodiversiteit). Vooral de ecologische kwaliteit moest verbeterd worden om het hemelwater vanuit de omliggende woonwijk af te kunnen koppelen. De maatregelen voor kwaliteitsverbetering zijn maar gedeeltelijk gerealiseerd.

De Zuidpolder is uit de landbouw gehaald waardoor stuwtjes verwijderd konden worden en plasdrassituaties zijn gerealiseerd, maar de natuur profiteert beperkt. Burgers die de stad uit willen profiteren van de ontwikkeling, maar het is meer stadspark dan wildernis.

\section{Economie}

Of de landbouw profiteert is de vraag. Wel is 20 hectare Zuidpolder ingericht voor stadslandbouw en kan er meer water vastgehouden worden. Qua woonmilieu kunnen mensen makkelijker het groen in. Qua ruimtelijke kwaliteit is de omgeving mooier en afwisselender geworden. Er zijn ook meer (sociale) faciliteiten.

Het hogere doel van dit project was om de klimaatbuffer op te schalen naar een veel robuustere eenheid van 1000 hectare in het Buijtenland van Rhoon, dat is niet gelukt. Het huidige oppervlak is 
kleiner, maar voldoende als natuurcompensatie voor de aanleg van Maasvlakte in het kader van de dubbeldoelstelling voor industrie en ecologische kwaliteit (planologische kernbeslissing).

\section{Succesfactoren}

- Bij een risico van verzilting is het zeer wenselijk zoetwater vast te houden. Dit project laat zien dat het mogelijk is zoetwater vast te houden op kleine schaal en in stedelijke omgeving.

\section{Faalfactoren}

- Burgers en landbouw kwamen in verzet: "geen natuur in onze achtertuin", "landbouw is cultuurhistorisch erfgoed van onze streek". Een omslag in denken werd niet gerealiseerd. Dit leidde ertoe dat opschaling niet is gelukt.

- Verzilting en eutrofiëring werden in deze casus niet als urgent gevoeld en de betrokken waterbeheerders gaven de voorkeur om deze effecten met traditioneel waterbeheer te mitigeren.

\section{$4.6 \quad$ Ilperveld}

Klimaatbuffer Ilperveld combineert een pilot en een groter gebiedsproject. De pilot 'Omhoog met het veen' ( 8 hectare voormalige landbouwgrond) is in 2013 gestart, gericht op het actief herstel van veenvormende natuur (veenmos) en het stoppen van bodemdaling door verhoging van het grondwaterpeil. De ontwikkeling van de veenmosakker en de emissie van broeikasgassen is op het proefproject en een referentielocatie (een veenweidegrasland met landbouwfunctie en een grondwaterstand van gemiddeld 50 centimeter onder maaiveld) drie jaar gevolgd (Landschap NoordHolland 2015; van de Riet et al. 2017).

De pilot is onderdeel van het project 'toekomst Ilperveld' waarin wordt gekeken wat er gedaan kan worden tegen bodemdaling, met herstel en ontwikkeling van natuur, natuurlijke oevers, hergebruik van bagger en hoe gebiedseigen water langer vastgehouden kan worden.

Het project 'toekomst Ilperveld' is op zijn beurt weer onderdeel van het project 'Amsterdam Wetlands' dat werkt aan een toekomstperspectief voor Laag-Holland, het veenweidegebied tussen Amsterdam en Alkmaar en de kusten.

\section{Klimaatadaptatie}

Op de schaal van het gehele veenweidegebied Laag-Holland verwacht Amsterdam Wetlands dat, bij grootschalige realisatie van vernatting, de bodemdaling op gebiedsniveau geremd kan worden en het gehele gebied daarmee klimaatbestendiger wordt. Lokaal (Waterland-Oost) zou vernatting van hooilanden en veenweides verdroging van de Markermeerdijk kunnen tegengaan.

\section{Klimaatmitigatie}

In de periode 2013-2016 is in het onderzoeksproject 'Omhoog met het Veen' een emissiereductie gerealiseerd van gemiddeld 3-5 ton $\mathrm{CO}_{2}$-eq ha- $\mathrm{jr}^{-1}$ ten opzichte van de referentie (landbouwperceel) ${ }^{9}$. In het proefproject werden lage methaanconcentraties ${ }^{10}$ gemeten in beide percelen. De $\mathrm{CO}_{2}$-emissie bepaalde in de pilot de broeikasgasbalans. De pilot liet een netto klimaatneutrale broeikasgasbalans (geen sink, maar ook geen source) zien. De verwachting is dat er na een aantal jaar zelfs netto koolstof wordt vastgelegd, doordat de veenafbraak sterk geremd wordt (van de Riet et al. 2017).

\section{Natuur}

In grote delen van de veenmosakkers van de pilot is een aaneengesloten tapijt van veenmossen gevormd. Tussen de veenmossen vestigen zich karakteristieke plantensoorten en paddenstoelen die horen bij het habitattype veenmosrietland. Monitoring blijft doorgaan om te verifiëren of soorten zich blijvend vestigen (van de Riet et al. 2017).

\footnotetext{
9 De gemiddelde broeikasgasemissie op het landbouwkundig referentieperceel in Ilperveld is aanmerkelijk lager vergeleken met andere meetlocaties met een landbouwfunctie in het Westelijk Veenweidegebied (zie hoofdstuk 5.2).

${ }^{10}$ De uitstoot van broeikasgas methaan neemt vaak toe bij vernatting waardoor de mitigatiepotentie van de maatregel kan afnemen (Vermaat and Aerts 2012).
} 


\section{Economie}

Het project besteedt aandacht aan paludicultuur, streekproducten voor het stedelijk gebied en recreatie. De omliggende melkveehouderijen ervaren de hoge waterpeilen als negatief. In het kader van de Klimaatenvelop 2019 voor veenweiden wordt daarom een bufferzone om het gebied aangelegd.

\section{Succesfactoren}

- $\mathrm{CO}_{2}$-vastlegging en tegengaan van bodemdaling zijn in dit project het vliegwiel voor biodiversiteitsherstel via het Deltaplan Biodiversiteitsherstel (Agrifirm et al. 2018).

- Dankzij deze speerpunten (vooral $\mathrm{CO}_{2}$ en bodemdaling) is het project onderdeel van het Interbestuurlijk Programma Vitaal Platteland.

- Het proefproject is uitgevoerd in een gecontroleerde omgeving waardoor de effecten redelijk eenvoudig aangetoond konden worden. Maar hoe is de pilot op te schalen?

\subsection{Anserveld/Leisloot}

De natuurlijke klimaatbuffer Anserveld/Leisloot (ook wel: Dwingelderveld) is een Natura 2000gebied met als belangrijkste doel verdroging van Natura 2000-natuur tegengaan en wateroverlast benedenstrooms (o.a. Meppel) voorkomen. In meerdere deelgebieden zijn maatregelen genomen: Anserveld, Dwingelderveld (Leisloot, Noordenveld, Benderse Plassen, boswachterij) en Kloosterveld ${ }^{11}$.

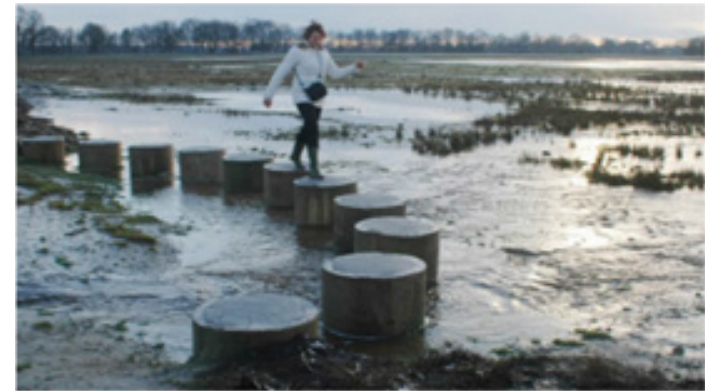

Foto: Natuurmonumenten

De maatregelen zijn gericht op waterberging en waterconservering met als natuurdoel vernatting van de heidegebieden en herstel van slenken. Dit moet leiden tot herstel en verbetering van kwaliteit van natte heide, heischraal grasland, actief hoogveen, slenkvegetaties met snavelbiezen, zure vennen en berkenbroekbos. Positieve verwachtingen zijn ook uitgesproken voor kamsalamander, roodborsttapuit en paapje.

Er zijn ook nevendoelen, namelijk vermindering van wateroverlast in de lager gelegen beekdalen, op landbouwgronden aan de randen van het natuurgebied en in de stadsrand van Meppel. De sponswerking van het gebied is verbeterd door oude stromen te herstellen en waterpeilen te verhogen. Door het nemen van inrichtingsmaatregelen, waaronder het omzetten van 150 hectare landbouwgrond in natuur (Paas 2016), kan hier bovendien nog eens $250.000 \mathrm{~m}^{3}$ water extra worden vastgehouden. Dit is een van de weinige klimaatbuffers waarbij een kwantitatief doel voor de sponswerking (waterretentie) is benoemd (CNK 2012).

\section{Klimaatadaptatie}

In de zomer van 2018 is de grondwaterstand gezakt tot meer dan 3,5 meter onder het maaiveld waar deze gemiddeld rond de 1,5 tot 2 meter onder het maaiveld ligt (figuur 4.1). Het was zo extreem droog dat de gevolgen voor natuur vermoedelijk even groot waren in gebufferde als in ongebufferde natuurgebieden ${ }^{12}$. De vraag is nu of het herstelvermogen van de natuur in Anserveld/Leisloot in de toekomst (2019/2020) groter zal zijn vergeleken met ongebufferde natuurgebieden.

\footnotetext{
${ }^{11}$ Ootmaanlanden maakt geen deel (meer) uit van deze klimaatbuffer. De Ootmaanlanden is wel weer toegevoegd aan het Programma Natuurlijk Platteland Drenthe als onderdeel van het programma Holtingerveld/ZW Drenthe.

${ }^{12}$ In een analyse van de droogte in 2018 met remote sensing van de groenmonitor (Roerink 2018) laten kaartbeelden geen verschillen zien in droogte-impact tussen Anserveld/Leisloot en omliggende gebieden. De beheerder van Natuurmonumenten gaf aan wel minder droogte-effecten te zien in flora en fauna van het Dwingelderveld, vergeleken met andere, nog niet herstelde vochtige heideterreinen in de directe omgeving (mond. med. Paul Vertegaal, Natuurmonumenten).
} 


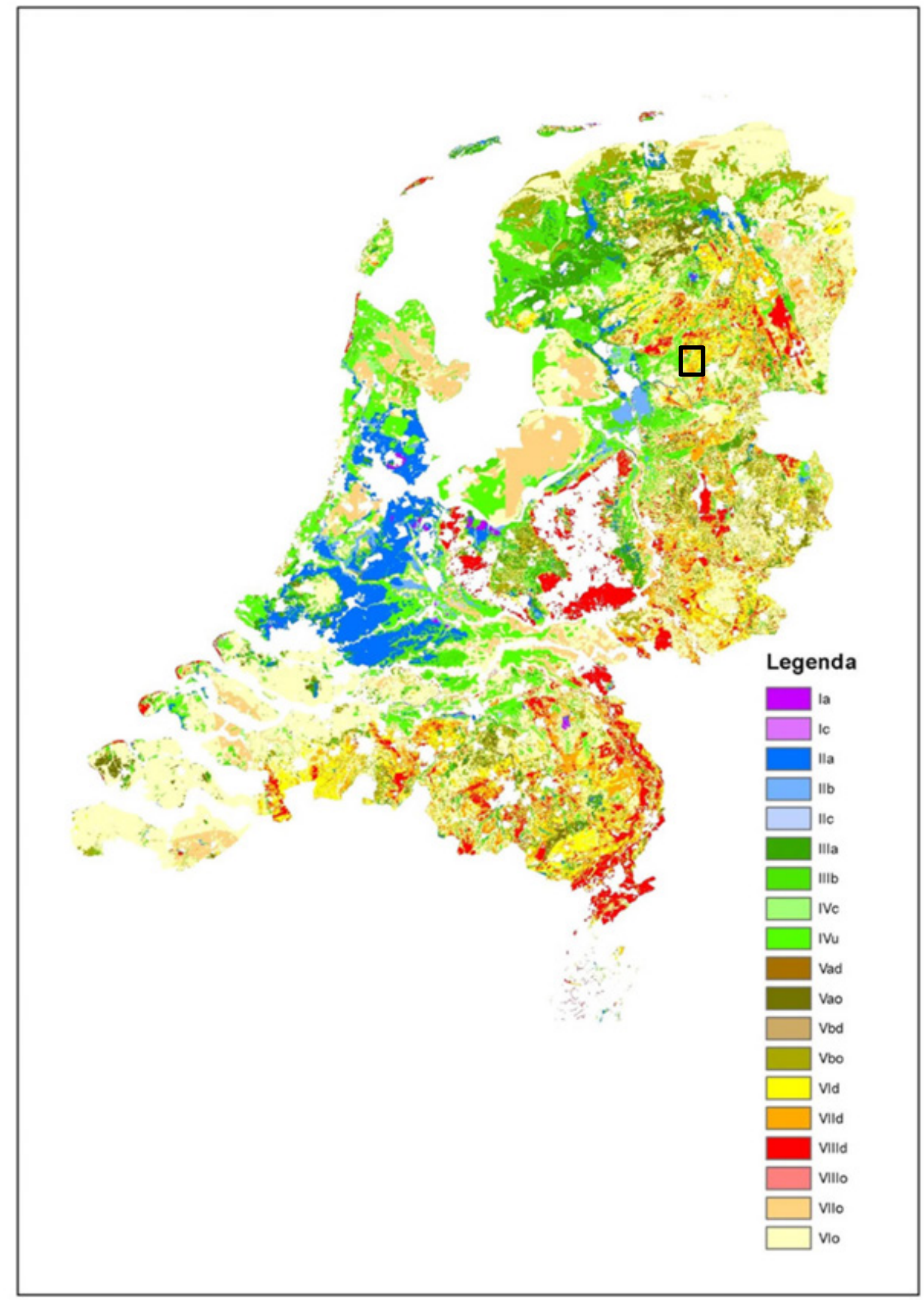

Figuur 4.1 Geactualiseerde kaart grondwaterdynamiek Nederland (Knotters et al. 2018) geclusterd naar grondwatertrappen. De grondwaterstand fluctueert in grote delen van Nederland op geringe diepte (0-200 cm beneden maaiveld), met ondiepe standen in de winter en diepe in de zomer. De grondwatertrappen zijn gebaseerd op gemiddeld hoogste (GHG) en laagste grondwaterstand (GLG). De klimaatbuffer Anservel/Leisloot ligt in het vierkant. In dit vierkant hebben alle grondwatertrappen een GLG van gemiddeld meer dan $180 \mathrm{~cm}$. 
Natuur

Tabel 4.3 geeft aan wat over natuureffecten gerapporteerd is na 2012 .

Tabel 4.3 Synoptisch overzicht van waargenomen natuureffecten in klimaatbuffer Anserveld/Leisloot na 2014 in vergelijking met de verwachtingen/doelen van voor 2014.

\begin{tabular}{|c|c|}
\hline Landnatuur & Waternatuur \\
\hline $\begin{array}{l}\text { De verwachting over herstel alle habitattypen binnen het } \\
\text { bestaande natuurgebied (natte heide, slenkvegetaties, } \\
\text { hoogveen, etc.) is gekwantificeerd (herstel van } 208 \text { ha) } \\
\text { (Paas 2016). Er is } 150 \text { ha nieuwe natuur gerealiseerd door } \\
\text { omzetten landbouwgrond en ca. } 50 \text { ha bestaande natuur } \\
\text { vernat. Natte heide en hoogveen zijn toegenomen (interview } \\
2019 \text {, geen data). }\end{array}$ & $\begin{array}{l}\text { Kamsalamanders zijn jaarlijks gezien in periode 2010- } 2016 \text {. } \\
\text { Onbekend is of populatie en verspreiding door de } \\
\text { maatregelen toe-/afneemt (Paas 2016). }\end{array}$ \\
\hline $\begin{array}{l}\text { Er is een praktijkproef uitgevoerd om te kijken naar het } \\
\text { effect van beheer op de bodemchemie van natte en droge } \\
\text { hei op voormalige landbouwgrond (Weijters et al. 2015). }\end{array}$ & \\
\hline $\begin{array}{l}\text { Er is geen informatie gevonden over effecten van de } \\
\text { maatregel op grondwaterstanden of de effecten van de } \\
\text { droogte in } 2018 \text { op grondwaterstanden. Wel bevestigt de } \\
\text { terreinbeheerder in het interview dat het terrein in } 2018 \\
\text { minder verdroogd is geweest in vergelijking tot andere } \\
\text { heidegebieden van Natuurmonumenten. }\end{array}$ & \\
\hline
\end{tabular}

De monitoring van habitattypen richt zich op vegetatietype, typische soorten, structuur en functie, abiotische randvoorwaarden en uitvoeringsmaatregelen. De abiotiek, waaronder grondwaterniveaus worden gemonitord via het PAS-monitoringsprogramma. Er zijn geen rapportages gevonden over het effect van de herinrichtingsmaatregelen op de grondwaterstand en aanverwante natuurwaarden zoals natte heide.

\section{Economie}

De gerealiseerde waterberging zorgt ervoor dat Meppel nu veel minder te maken heeft met wateroverlast bij langdurige neerslag. Dankzij de sponswerking (waterretentie) kan beregening in de landbouw langer worden uitgesteld in tijden van droogte. Men dacht dat de toeristen niet van natte voeten zouden houden maar dat blijkt niet waar. Er is duidelijk jaarrond toerisme. Daarbij hebben de extra euro's van de CNK geholpen, want zo konden fietspaden bijvoorbeeld worden opgehoogd. Toeristen vinden het prachtig om stromend water te zien, dus nattigheid biedt kansen.

Er zijn veel beheerkosten voor het habitattype 'natte heide': er zijn speciale machines nodig vanwege de drassigheid en de stikstofdepositie leidt ook tot een grotere kostenpost voor beheer. Anderzijds zorgen hogere waterstanden voor betere natuurkwaliteit en daarmee minder beheer.

\section{Succesfactoren}

- Meekoppelkansen waren een succesfactor: realisatie natte heide was een EU-doel, landbouw omvormen naar natuur was een doel vanuit de provincie, water vasthouden en bergen was een doel van het waterschap en de infrastructuur was een doel van de gemeente. Hiermee zijn ook budgetten aan elkaar gekoppeld.

- "De titel klimaatbuffer helpt zeker, en het helpt nog steeds. Het geeft vleugels." (Projectleider). 
De Oesterdam is een compartimenteringsdam in het oosten van de Oosterschelde, aangelegd voor scheepvaart en zoetwatervoorziening van de eilanden. Door deze dam staat de Oosterschelde niet meer in verbinding met de Rijn en Schelde en is de Oosterschelde veranderd in een baai met zoutwater en getij. Door de dam en de Oosterscheldekering eroderen vooroevers en zandplaten waardoor platen en slikken verlagen en het areaal aan intergetijdengebied in de Oosterschelde jaarlijks afneemt met circa 50 hectare: 'zandhonger' (Eelkema et al. 2013; Van Zanten and Adriaanse 2008). Daardoor staat vooral de voedselvoorziening voor vogels op de internationale trekroute, onder druk.

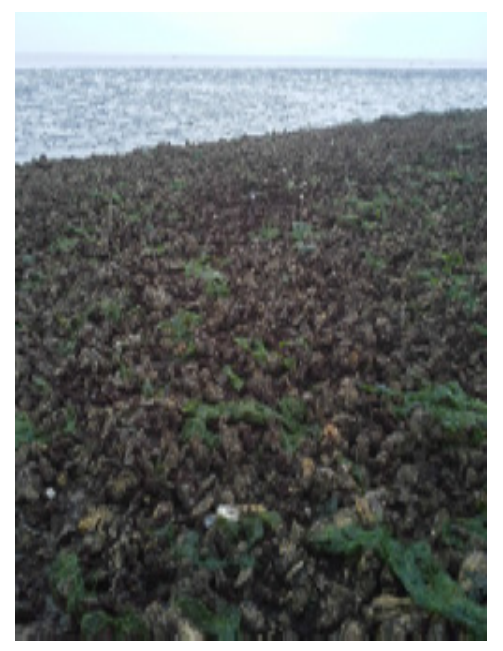

Foto: Oesterrif (Jeroen Veraart, 2019).

Als onderdeel van de klimaatbuffer Oesterdam is over een lengte van 2 kilometer meer dan $500.000 \mathrm{~m}^{3}$ zand aangebracht (vooroever), in combinatie met kunstmatige oesterriffen. Deze hebben primair tot taak om wegspoelend zand in te vangen, maar zouden ook goed te gebruiken zijn voor oesterbroed, waardoor ze een positieve bijdrage leveren aan de oester- en visserijsector. Na het aanbrengen van het zand kan regulier beheer van de primaire kering met 20-30 jaar uitgesteld worden, was de hypohese. Natuurmonumenten zag het project als een pilot 'zandhongerbestrijding' door middel van een zandmotor. De ervaringen zouden kunnen worden gebruikt op grotere schaal, bijvoorbeeld om de Roggenplaat te behouden. De instandhouding van het intergetijdengebied geeft ruimte voor recreatie (watersport, wandelen, vogelaars). De klimaatbuffer is te klein om de zandhonger in de Oosterschelde tegen te kunnen houden. Hiervoor zullen meer systeemingrepen en aanleg van plaat- en vooroeversuppleties op diverse plaatsen in de Oosterschelde nodig zijn (opschaling). Hierover wordt in de Programmatische Aanpak Grote Wateren nagedacht.

\section{Klimaatadaptatie}

De waterpeilstijging onder de KNMI-scenario's in de Oosterschelde valt veelal binnen de marge van de huidige waterveiligheidstoets- en ontwerpwaarde voor de betreffende dijkvakken (Ministerie van Verkeer en Waterstaat 2007). De dijkvakken zijn vaker sterker dan strikt noodzakelijk. Door de zeespiegelstijging neemt de marge tussen toets en ontwerpwaarde echter af voor dijklichamen in de Oosterschelde (Veraart et al. 2016). Meegroeien met de zeespiegelstijging is in de Oosterschelde onmogelijk gezien het grote tekort op de zandbalans en door het feit dat er door de aanwezigheid van de kering vrijwel geen netto zandimport plaatsvindt. Grootschalige zandsuppleties door de mens zijn dus nodig om geulen, platen en schorren in de Oosterschelde mee te kunnen laten groeien met de zeespiegelstijging (Haasnoot et al. 2018).

\section{Natuur}

Bij de Oesterdam is het zeldzame klein zeegras aangetroffen, hoewel onduidelijk is of het om een ecologisch veerkrachtige populatie gaat. Niettemin geeft de vondst aan dat deze betrekkelijk nieuwe zandplaat nu al geschikt is voor deze onderwaterplant. Wanneer grote velden zich zouden herstellen in de Oosterschelde kunnen deze fungeren als kraamkamer en schuilplaats voor vis- en schelpdiersoorten.

De oesterriffen bij de Oesterdam gaan bijdragen aan de handhaving van de oester in dit gebied. Allerlei soorten zullen profiteren van het oesterrif en zich hier jaarrond of een deel van het jaar vestigen. Door de instandhouding van het intergetijdengebied blijft voor kwetsbare soorten een goed en groot leefgebied beschikbaar. De klimaatbuffer zorgt ervoor dat steltlopers en zeehonden langer kunnen blijven foerageren, rusten en/of zogen. Het gebied is van grote betekenis voor bodemdieren 
(tabel 4.4). Aan de hand van vogeltellingen, macrofaunabemonsteringen en gebied dekkende opname van het bodemleven zal monitoring van de ecologie plaatsvinden.

Tabel 4.4 Overzicht van ontwikkelingen na 2014 voor land-en waternatuur waarvoor verwachtingen waren geformuleerd.

\begin{tabular}{ll} 
Landnatuur & Waternatuur \\
Geen doelen voor landnatuur in 2014. & Klein zeegras (Zostera noltei) gesignaleerd (Walles et al. \\
& 2018), maar ook definitief gevestigd? \\
\hline & Er is intergetijdengebied gerealiseerd, maar dat erodeert \\
ook weer langzaam: dat is ook de bedoeling. Het is niet aan & te tonen dat deze maatregel op systeemniveau de \\
zandhonger kan remmen (kleiner maken dan 50 ha jr ${ }^{-1}$ voor & de hele Oosterschelde). \\
& Waterbodemleven ontwikkelt zich beter dan verwacht \\
(voedsel voor de vogels).
\end{tabular}

\section{Economie}

De kosten van het project waren circa $€ 3,5$ miljoen. Recreanten maken dankbaar gebruik van de nieuwe zandplaten, er worden veel wandelaars en vogelaars gespot, soms ook op plekken waar ze de vogels verstoren. De oesterriffen bieden mogelijkheden voor schelpdierkweek.

Met vooroeversuppleties, zoals toegepast bij de Oesterdam, kunnen de marges tussen toets- en ontwerpwaarde gehandhaafd blijven en kan groot onderhoud van het dijkvak of compartimenteringsdam over een langere tijdsperiode verspreid worden, tot na 2060. Daarnaast kan de reductie in golfbelasting door vooroeversuppleties tot $25 \%$ bedragen in de Oosterschelde (Tonnon and Mulder 2013). Dit levert ook een kostenbesparing op voor regulier onderhoud (tabel 4.5). Beide kostenbesparingen voor dijkonderhoud moeten echter afgewogen worden tegen de kosten van de vooroeversuppletie. Volgens het rapport 'Perspectief Natuurlijke Keringen' blijkt uit studies dat voor ongeveer de helft van de dijken in de Oosterschelde zandsuppletie kosteneffectiever is. Wel is de kanttekening gemaakt dat in alle gevallen sprake is van maatwerk en dat de financiële aspecten daar ook van afhangen (Fiselier et al. 2011).

Tabel 4.5 Overzicht van nieuwe inzichten over kosten en baten in relatie tot KB-project Oesterdam waarvoor ook verwachtingen/doelen zijn geformuleerd (voor 2014).

\begin{tabular}{|c|c|c|}
\hline Klimaatbuffer & $\Delta$ Kostenbesparing & $\triangle$ Extra Baten \\
\hline Oesterdam & $\begin{array}{l}\text { Uitstel regulier onderhoud primaire } \\
\text { kering, } 20 \text { jaar bij hoofdsuppletie en } \\
30 \text { jaar bij dijkvoet, zorgt voor } \\
\text { kostenbesparing (Walles et al. 2018). }\end{array}$ & $\begin{array}{l}\text { Kansen voor recreatie }(+) \text {, maar er zijn ook } \\
\text { negatieve effecten voor natuur (ongewenste } \\
\text { plaatlopers, interview). }\end{array}$ \\
\hline
\end{tabular}




\section{Succesfactoren}

- Er is veel van andere proefsuppleties geleerd, zoals bijvoorbeeld het Sophiastrand (Projectbureau Zeeweringen 2012).

- De recreatie is vormgegeven aan de hand van lokale wensen. Met deze oplossing zijn kosten uitgesteld voor Rijkswaterstaat en is nieuwe natuur gerealiseerd met waarde voor de natuurterreinbeheerders.

- Mede gestimuleerd door deze klimaatbuffer heeft Natuurmonumenten met de crowdfundings-actie 'Red de Roggenplaat' (5600 'zandtekeningen') lokaal draagvlak gegenereerd voor de aanpak van zandhonger in de Oosterschelde. Dat bleek een katalysator voor het ministerie om suppleties bij de Roggenplaat te prioriteren.

- De klimaatbuffers die samen met Rijkswaterstaat of stichting EcoShape worden gedaan in de Zuidwestelijke Delta, kustzone en Waddengebied (typen 'Biobouwers' en 'Levende Kust') worden, verhoudingsgewijs, beter gemonitord dan de klimaatbuffers rondom de stad en op de hoge zandgronden (van Sluis et al. 2012). De kennisinstellingen werken hierbij samen (o.a. NIOZ, Deltares, Wageningen Marine Research, hogeschool HZ). 


\section{$5 \quad$ Bijdragen aan klimaatbeleid, natuurdoelen en economische ontwikkeling}

Tijdens de deskstudie is geïnventariseerd wat klimaatbuffers bijdragen aan klimaatbeleid, natuurdoelen en economische ontwikkeling. De resultaten zijn hier toegelicht per type klimaatbuffer.

\subsection{Klimaatbuffertype Groenblauwe Ruimte}

\subsubsection{Inleiding}

Het klimaatbuffertype 'Groenblauwe Ruimte' is in deze evaluatie opgesplitst in twee typen:

- KB-projecten waarbij extra bergingscapaciteit voor oppervlaktewater wordt gerealiseerd in combinatie met natuurontwikkeling rondom de grote rivieren. Dit wordt gerealiseerd, hetzij door verlaging van zomer- of winterbed binnen de banddijken, hetzij door verbreding van het winterbed door teruglegging van de dijken.

- KB-projecten waarin extra oppervlaktewaterberging gerealiseerd wordt buiten het hoofdwatersysteem, in en om lagergelegen natuurgebieden (zoals meren, moerassen en beekdalen), voornamelijk gelegen in het peri-urbane gebied. Zo kan neerslag tijdens piekbuien naar de natuurgebieden afgevoerd worden ('natuurlijke waterberging'), waardoor het omliggende stedelijk en landelijk gebied droge voeten houdt (CNK 2019).

Van de natuurlijke klimaatbuffers die tussen 2008 en 2014 gerealiseerd zijn (figuur 2.2) zijn er veertien gekwalificeerd als 'Groenblauwe Ruimte', waarvan zes rivierprojecten (tabel 5.1) en negen projecten in lagergelegen gebieden met waterberging rondom steden en beekdalen (tabel 5.2). Van deze klimaatbuffers zijn de projecten Ooijen-Wansum, rivierklimaatpark IJsselpoort, De Onlanden en IJsselmonde eerder behandeld (hoofdstuk 4) en zijn daarom niet uitgewerkt in de tabellen.

Tabel 5.1 Overzicht van klimaatbufferprojecten van het type Groenblauwe Ruimte bij rivieren die gestart zijn in 2008-2014.

\begin{tabular}{ll} 
Projectnaam & Toelichting status, belangrijkste leerpunten na 2014 \\
Smart Rivers & Smart Rivers is een strategisch concept dat concreet houvast \\
& biedt bij het vormgeven en bewaken van de landschappelijke en \\
ecologische kwaliteit van grote rivierprojecten door het maken & van informatieve materialen, de organisatie van master classes \\
& en verankering van rivierkennis in onderwijs (Stichting Smart \\
& Rivers 2019). \\
\hline Waalweelde-Beuningen & Succesvol project, o.a. door gezamenlijke vergunningsaanvraag \\
& voor de klimaatbuffer en de Stroomlijn-opgave van \\
& Rijkswaterstaat (Ofori 2018). Opschaling ingezet via programma \\
Waalweelde van de provincie Gelderland (ARK & Natuurontwikkeling 2018). \\
\hline Ooijen-Wanssum & Zie sectie 4.3 \\
\hline Zivierklimaatpark IJsselpoort (fase I en II) &
\end{tabular}


Tabel 5.2 Overzicht van klimaatbufferprojecten van het type Groenblauwe Ruimte rondom de stad en in beekdalen.

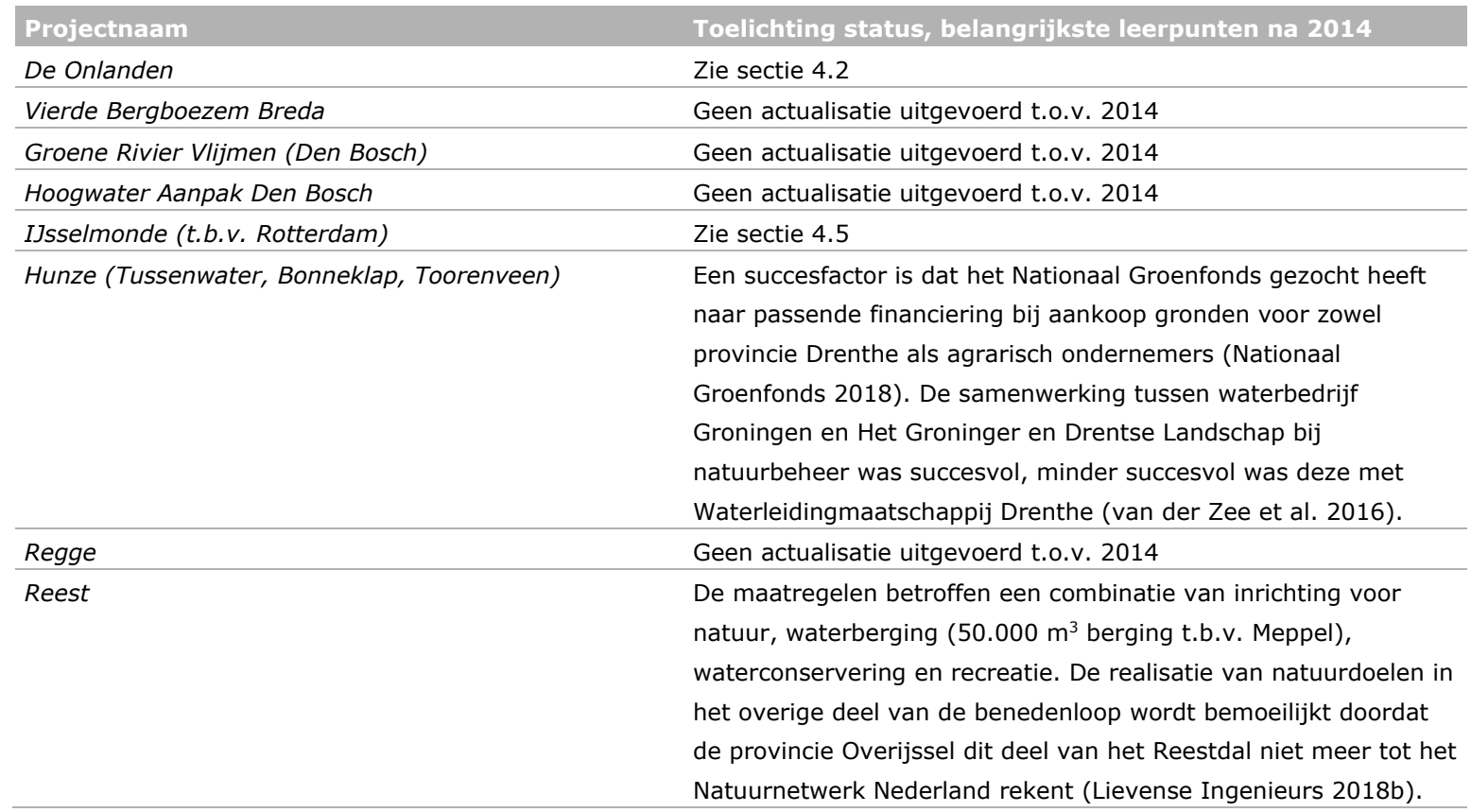

\subsubsection{Bijdragen aan klimaatbeleid, natuurdoelen en economie}

Voor het klimaatbuffertype 'Groenblauwe Ruimte' wordt per evaluatiecriterium omschreven welke generieke leerpunten te benoemen zijn. Hierbij is aanvullende informatie verzameld binnen de deskstudie.

Klimaatadaptatie (waterberging rond rivier en stad)

Voor de meeste van dit type klimaatbuffers (gestart voor 2014) wordt het vergroten van oppervlaktewaterberging om piekafvoeren van rivieren of beken op te vangen expliciet benoemd als doelstelling in de CNK evaluaties van 2012 en 2014 (figuur 5.1). Er zijn ook KB-projecten van het type 'Natuurlijke Spons' (Kempen-Broek, Weerterbos) die voor oppervlaktewaterberging een doelstelling hebben geformuleerd. Op de kaart zijn de grenzen van de 21 Nederlandse waterschappen aangegeven. De eerste Klimaatbufferprojecten (2008-2014) hebben bijgedragen aan de waterbergingsopgaven van de waterschappen Noorderzijlvest, Hunze en Aa's, Aa en Maas, Hollandse Delta, Brabantse Delta, Limburg, Vechtstromen en Drents-Overijsselse Delta. De meeste hiervan zijn vooral gelokaliseerd in het landelijk gebied van Oost-Nederland en rondom enkele steden (Groningen, Breda, Rotterdam).

Figuur 5.1 geeft ook aan welke klimaatbuffers vooraf een kwantitatief doel voor waterberging hebben geformuleerd (donkerblauwe waterdruppels) en welke een kwalitatief doel (lichtblauw). De doelstelling is meestal uitgedrukt in $\mathrm{m}^{3}$ waterberging en in enkele gevallen in een daling van het risico in wateroverlast of een te realiseren waterstandsverlaging in een rivier (Ooijen-Wansum, WaalweeldeBeuningen).

Natuurterreinbeheerders hebben tussen 2008 en 2014 ook andere terreinen ingericht volgens het klimaatbufferprincipe die niet aangemerkt zijn als natuurlijke klimaatbuffer. Ook zijn er vergelijkbare projecten gerealiseerd door waterschappen en provincies, op terreinen van drinkwaterbedrijven en Rijkswaterstaat die ook als een natuurlijke klimaatbuffer geoormerkt zouden kunnen worden. Een voorbeeld hiervan zijn herinrichtingsprojecten rondom steden in de Randstad waarbij natuurherstel en -ontwikkeling is gecombineerd met o.a. waterberging en recreatie in het kader van het Recreatie om de Stad-programma (RodS) op circa 15.000 hectare (PBL 2010). 


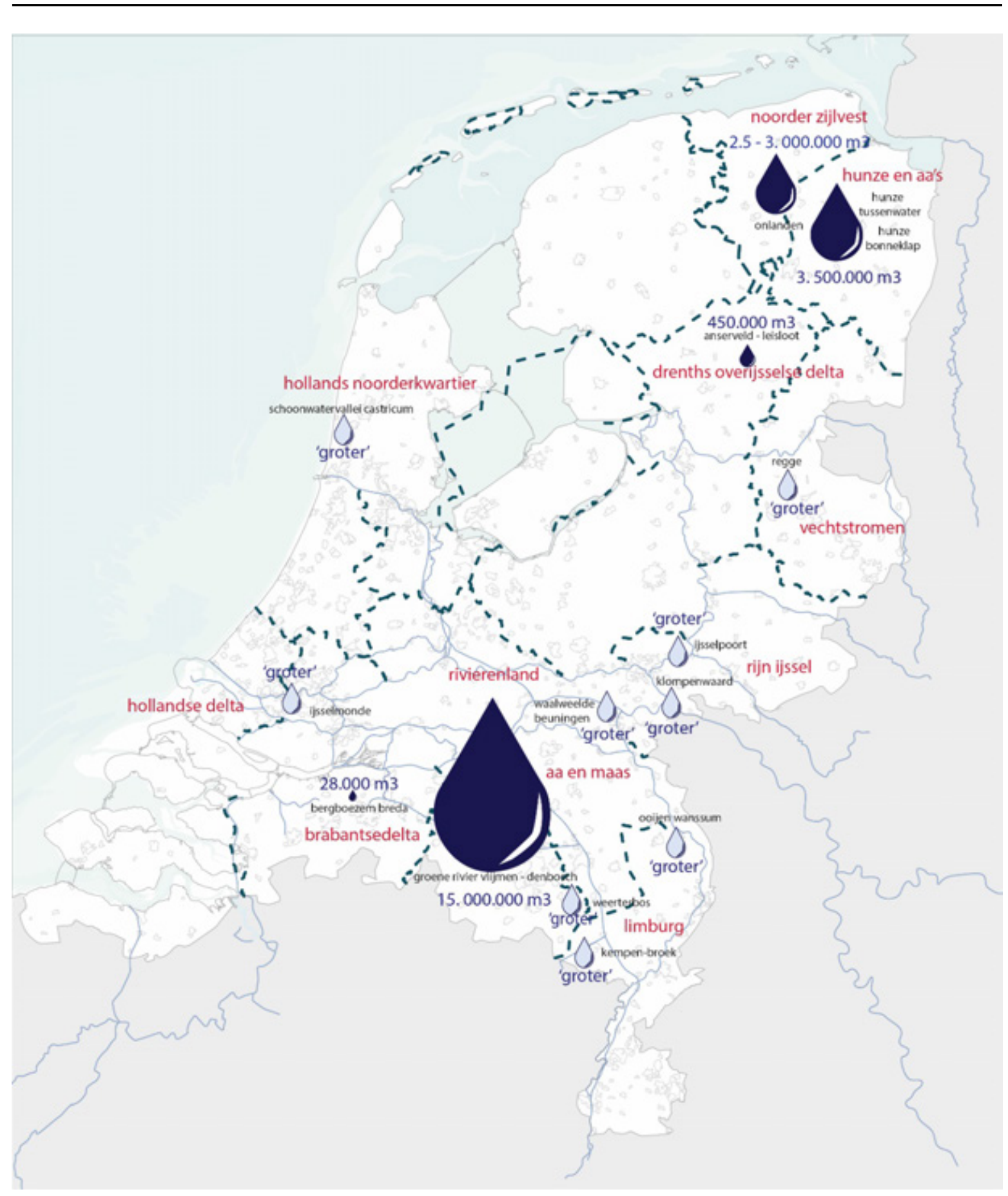

Figuur 5.1 Overzicht van de natuurlijke klimaatbuffers met het doel om extra waterbergingscapaciteit te realiseren bij piekafvoeren in verschillende waterschappen.

\section{Klimaatmitigatie}

Verschillende klimaatbuffers van het type Groenblauwe Ruimte zijn ook te kwalificeren als een koolstof-sink (KB-Onlanden, KB Hunze). Dit wordt besproken in sectie 5.2.

\section{Natuur}

Het is niet bij elk KB-project van het type Groenblauwe Ruimte rondom de steden gelukt om het project optimaal in te richten voor natuurdoelen (voorbeeld IJsselmonde). Wel is er ten opzichte van de uitgangssituatie altijd sprake van winst voor de natuur en biodiversiteit.

Bij de klimaatbuffers in het rivierengebied is nu meer ruimte voor de bijbehorende natuurlijke processen zoals natuurlijkere waterstanden en begrazing. Door wegzijging en het creëren van plasdras-situaties ontstaan er meer kansen voor laag-dynamische natuur. Nieuwe moerasnatuur en 
herstel van landnatuur is lokaal bij verschillende KB-projecten gerealiseerd in zowel peri-urbaan gebied als rondom de rivieren.

\section{Economische aspecten - kosten}

De economische aspecten van natuurontwikkeling in combinatie met waterberging zijn in kaart gebracht voor de KB-projecten De Onlanden, Hunze en Anserveld/Leisloot ${ }^{13}$ (tabel 5.3). De gerealiseerde waterberging en bijbehorende kosten zijn bepaald op basis van beschikbaar MERonderzoek. De kosten zijn per hectare en per kubieke meter uitgerekend om inzicht te geven in de kosteneffectiviteit.

De kostprijs per kuub waterberging varieert in deze voorbeelden tussen de 2 en 4 euro. In vergelijkbare waterbergingsprojecten zijn kostprijzen gerapporteerd van $€ 0,45 \mathrm{~m}^{-3}$ (Onner- en Oostpolder/Hunze), $€ 4,44 \mathrm{~m}^{-3}$ (Hoogwater project Den Bosch (HowaBo)) en $€ 1,40 \mathrm{~m}^{-3}$

(Eendrachtspolder). De kosten zijn locatie-afhankelijk en het maakt veel uit of er grond moet worden aangekocht. Wanneer grondaankoop onderdeel is van de herinrichting gaat de kostprijs omhoog.

Economische aspecten - baten

De baten van de klimaatbufferaanpak voor natuurbeleid, waterkwaliteit en economische gebiedsontwikkeling (recreatie) bij waterberging bleken in deze voorbeelden vaak doorslaggevender dan de kosten bij de afweging tussen plan-alternatieven (zie hoofdstuk 4).

De baten van extra oppervlaktewaterberging worden vaak uitgedrukt in een lager risico op schade door wateroverlast voor landbouw (Mulder et al. 2018) of woningbouw (van der Most et al. 2017). Ook zijn er methoden ontwikkeld wat extra oppervlaktewaterberging voor beekdal-natuur kan betekenen in bijvoorbeeld de Baakse Beek (Witte et al. 2018). Dit soort instrumenten zijn nog niet gebruikt voor natuurlijke klimaatbuffers uit het CNK-programma.

Er zijn, in potentie, nog meer baten te realiseren door oppervlaktewaterberging te combineren met koolstofvastlegging (zie paragraaf 5.2) of waterretentie (paragraaf 5.4). De baten van waterretentie (sponswerking) zijn bij KB-projecten moeilijk te kwantificeren. Als de baten voor natuur, drinkwatervoorziening en recreatie ook in financieel rendement vertaald zouden worden, dan neemt het rendement verder toe.

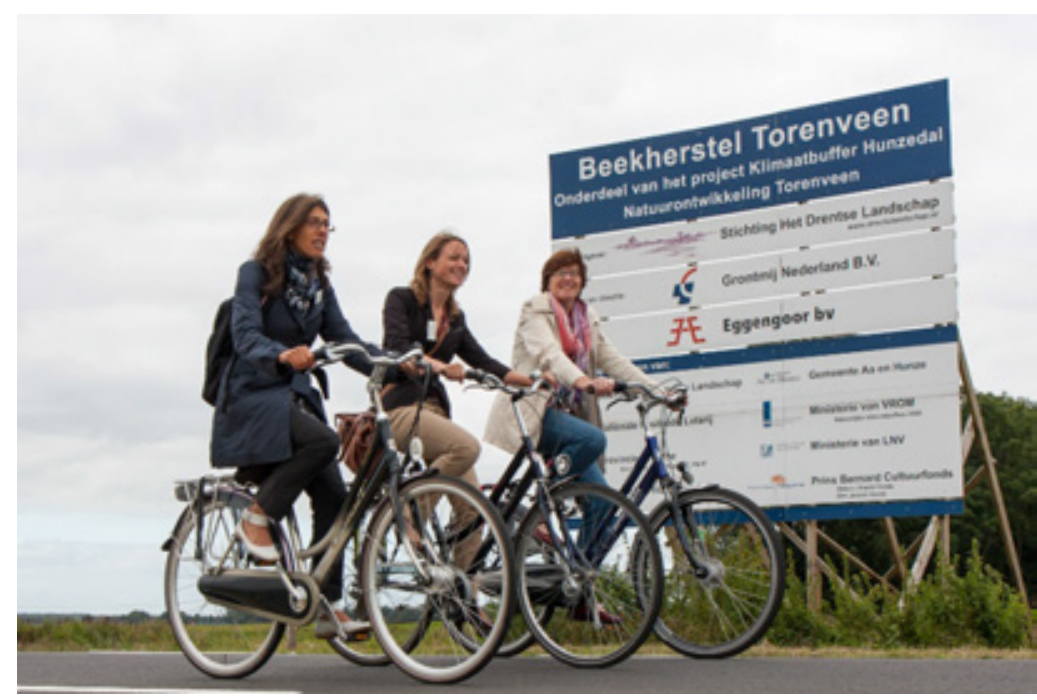

Beekherstel Torenveen als onderdeel van de Hunze (Foto: Coalitie Klimaat Buffers).

\footnotetext{
${ }^{13}$ Formeel een klimaatbuffer van het type Natuurlijke Spons, maar er is ook oppervlaktewaterberging gerealiseerd.
} 
Tabel 5.3 Overzicht van de bijdragen aan klimaat, natuur en economie doelen van natuurlijke klimaatbuffers De Onlanden, Hunze en Anserveld/Leisloot.

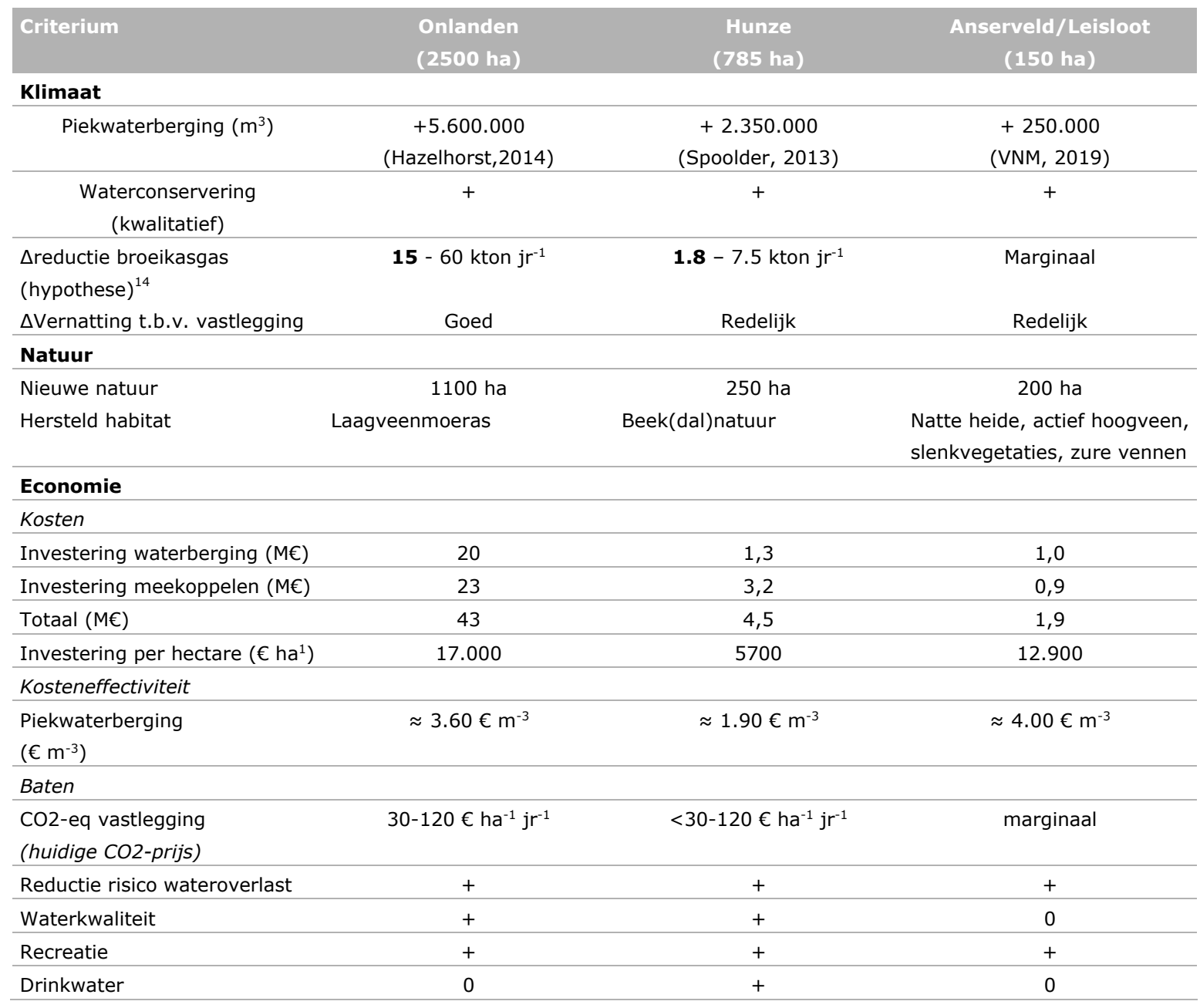

\section{$5.2 \quad$ Koolstof-sink}

\subsubsection{Inleiding}

In de visie van de CNK draagt dit type klimaatbuffers bij aan klimaatadaptatie (water vasthouden en kustbescherming) én aan klimaatmitigatie, door broeikasgasemissies tegen te gaan en koolstof op te slaan. Dat wordt bereikt door veenherstel en uitbreiding van zoutmoerassen, schelpdierbanken, zeegrasvelden en kwelders (CNK 2019).

Bij de eerste generatie klimaatbuffers was de bijdrage van projecten aan klimaatmitigatie nooit een expliciete doelstelling, maar er zitten wel KB-projecten tussen die potentie hebben om ook netto broeikasgassen vast te leggen of de emissies ervan te reduceren zoals De Onlanden en de Hunze.

\footnotetext{
${ }^{14}$ De toelichting op deze schatting staat in hoofdstuk 5.2 .
} 


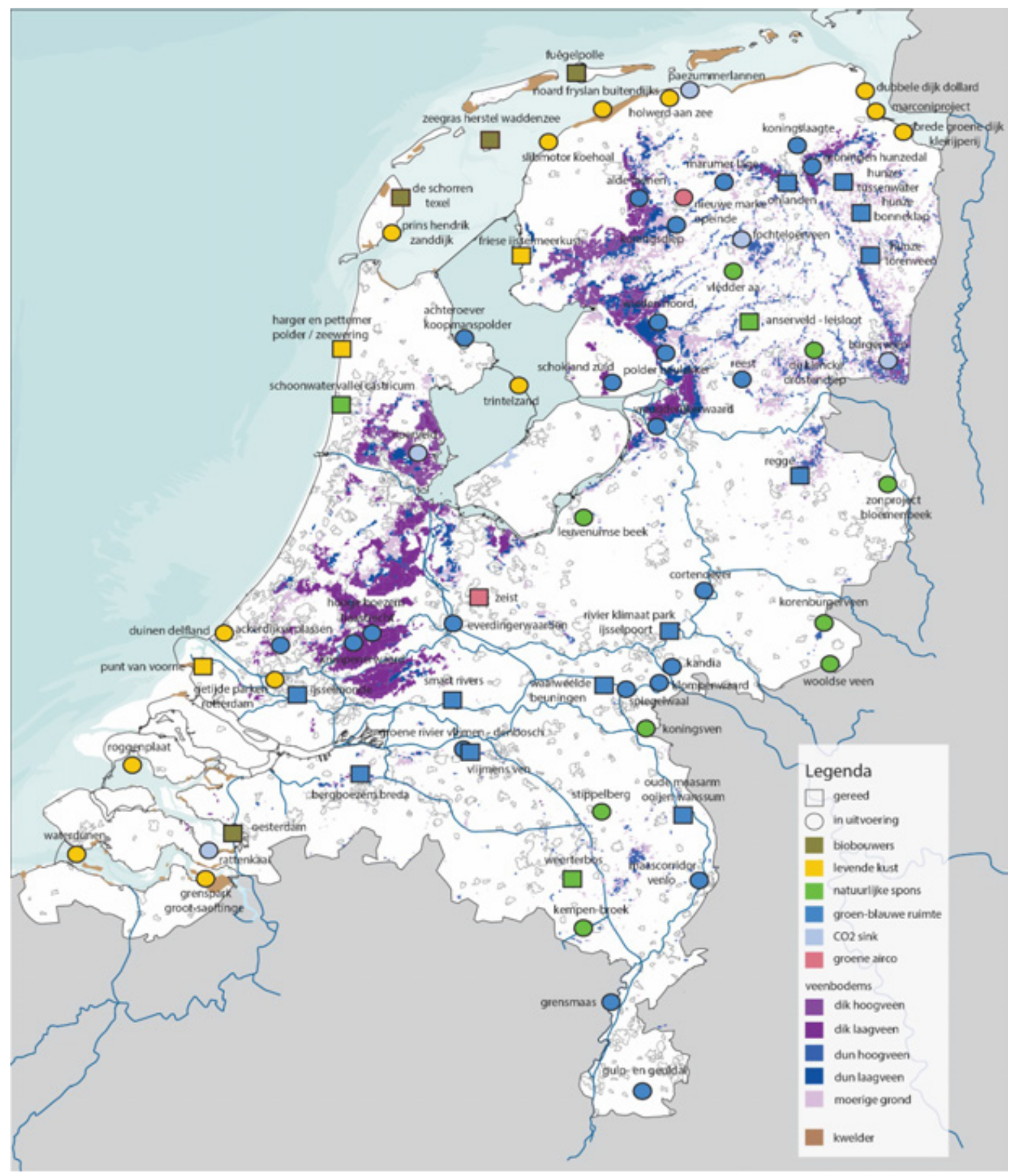

Figuur 5.2 Natuurlijke Klimaatbuffers geprojecteerd op kaart met locaties veen (paars) en kwelders (bruin).

Figuur 5.2 toont alle klimaatbuffers (ook de klimaatbuffers die na 2012 gerealiseerd zijn) op een kaartprojectie met alle veengronden (paars) en kwelders (bruin).

Het paarse gebied op deze kaart is een optelsom van moerige gronden (1914 $\mathrm{km}^{2}$ ) en bodems met een dikker veenpakket (3369 $\mathrm{km}^{2}$ ) (Arets et al. 2019). Dit areaal veengrond is veel groter dan het areaal veenweidegebied; schattingen van het oppervlakte veenweidegebied in Nederland variëren in de literatuur tussen 2400 en 2900 km$^{215}$. De verschillen in schattingen zijn een gevolg van aangepaste/verschillende definities voor het begrip 'veenweide', het daadwerkelijk oxideren van veenbodem (areaalafname in de tijd) of functieveranderingen (toename stedelijk gebied). Een

\footnotetext{
${ }^{15}$ De oorspronkelijke bronnen van de schattingen voor het areaal veenweidegebied in de literatuur die tussen 1990 en 2004 genoemd worden zijn moeilijk te herleiden, maar het gaat vaak om interpretaties van verschillende versies van de nationale bodemkaart (1:50:000) (De Vries et al. 2003).
} 
veenweidegebied is een Nederlands landschapstype bestaande uit weiden op veengrond. Stedelijke gebieden, die niet onder deze definitie vallen, kunnen bijvoorbeeld ook op veengrond liggen.

Er liggen vijftien klimaatbuffers op veen of moerige grond, ongeveer evenredig verdeeld over ontgonnen of 'intact' hoogveen (zoals Fochteloërveen) en laagveen (zoals Ilperveld). Voorbeelden van KB-projecten bij kwelders zijn Marconi Buitendijks Delfzijl en Peazemerlanden. In het rivierengebied ligt een klimaatbuffer waar koolstofvastlegging is gerealiseerd door aanleg van bos in de uiterwaarden (Ooijen-Wansum). Het hangt van de aard van de projecten af, of hier daadwerkelijk extra vastlegging van broeikasgassen of reductie van emissies mogelijk is.

Tabel 5.4 geeft een overzicht van de klimaatbuffers die binnen de deskstudie nader beschouwd zijn in aanvulling op het interview met de projectleider van De Onlanden (sectie 4.2).

Tabel 5.4 Kennisactualisatie Bargerveen en Fochteloërveen.

\begin{tabular}{|c|c|}
\hline Klimaatbuffer & Actualisatie \\
\hline Bargerveen (bron: interview) & $\begin{array}{l}\text { Natuurherstelproject in Noordoost-Nederland. Er zijn ook maatregelen getroffen om } \\
\text { in drie buffergebieden om het Bargerveen grondwater langer vast te houden (dus } \\
\text { ook een natuurlijke spons) die leiden tot extra } \mathrm{CO}_{2} \text {-vastlegging, er is } \mathrm{CO}_{2} \text {-verlies } \\
\text { voorkómen bij uitvoering van hydrologische herstelmaatregelen door slim gebruik } \\
\text { van leemruggen, en er zijn meekoppelkansen gecreëerd voor recreatie. } \\
\text { Sinds de zomer van } 2019 \text { is er een hydrologisch model gereed om het } \\
\text { watervasthoudend vermogen van dit gebied (sponswerking) in te schatten. }\end{array}$ \\
\hline Fochteloërveen & $\begin{array}{l}\text { Fochteloërveen is een omvangrijk restant hoogveen (habitattype H7120) van } \\
2.600 \text { ha waar herstelmaatregelen genomen zijn. Uitbreiding van kenmerkende } \\
\text { soorten veenmossen is opgetreden (de Hoop et al. 2011) en er is een klein areaal } \\
\text { actief groeiend hoogveen (Jansen et al. 2013). Belangrijke vraag is wat de effecten } \\
\text { van klimaatverandering zijn (droogte) op de CO2-eq-vastleggingscapaciteit en } \\
\text { koolstofvoorraad van gebieden waar herstel van hoogveen wordt overwogen } \\
\text { (Limpens et al. 2016; Natuurmonumenten 2019). De zomers van } 2018 \text { en } 2019 \\
\text { hebben het beheer van het Fochteloërveen bemoeilijkt door het bezwijken van een } \\
\text { flink aantal houten damwanden in en om het gebied. Natuurmonumenten bereidt } \\
\text { daarom grootschalig herstel voor. }\end{array}$ \\
\hline
\end{tabular}

\subsubsection{Bijdragen aan doelen klimaat, natuur en economie}

Voor het klimaatbuffertype Koolstof-Sink wordt alleen ingegaan op evaluatiecriteria 'klimaatmitigatie' en 'economie'. Voor deze criteria is voor dit type klimaatbuffer aanvullende informatie verzameld. Dit type klimaatbuffers draagt ook bij aan 'natuur' en 'klimaatadaptatie' door koolstofvastlegging te combineren met waterberging (sectie 5.2) en waterconservering (sectie 5.4). Dit is al aan bod gekomen in de sectie 5.2 en 4.2 .

\section{Klimaatmitigatie}

Natte natuur in veenweidegebieden, kwelders en (rivier)bos is een belangrijke locatie voor netto vastlegging van broeikasgassen, het verminderen van de $\mathrm{CO}_{2}$-uitstoot of de opwekking van (bio)energie (van den Born et al. 2002). Ook de bescherming van bestaande koolstofvoorraden kan een belangrijke reden zijn voor het realiseren van natuurlijke klimaatbuffers.

De vastlegging en emissie van land gebonden broeikasgassen kunnen op een locatie van jaar tot jaar sterk variëren (o.a. door het weer). Dit illustreert figuur 5.3. In een droog jaar kan een grasland een netto emissiebron zijn, terwijl in een nat jaar er netto broeikasgassen worden vastgelegd (Jacobs et al. 2008). De uitstoot en vastlegging van broeikasgassen hangt tevens af van het type bodem, het perceel gebonden waterbeheer en de vorm van natuurbeheer of landbouw (Schulp et al. 2010). 


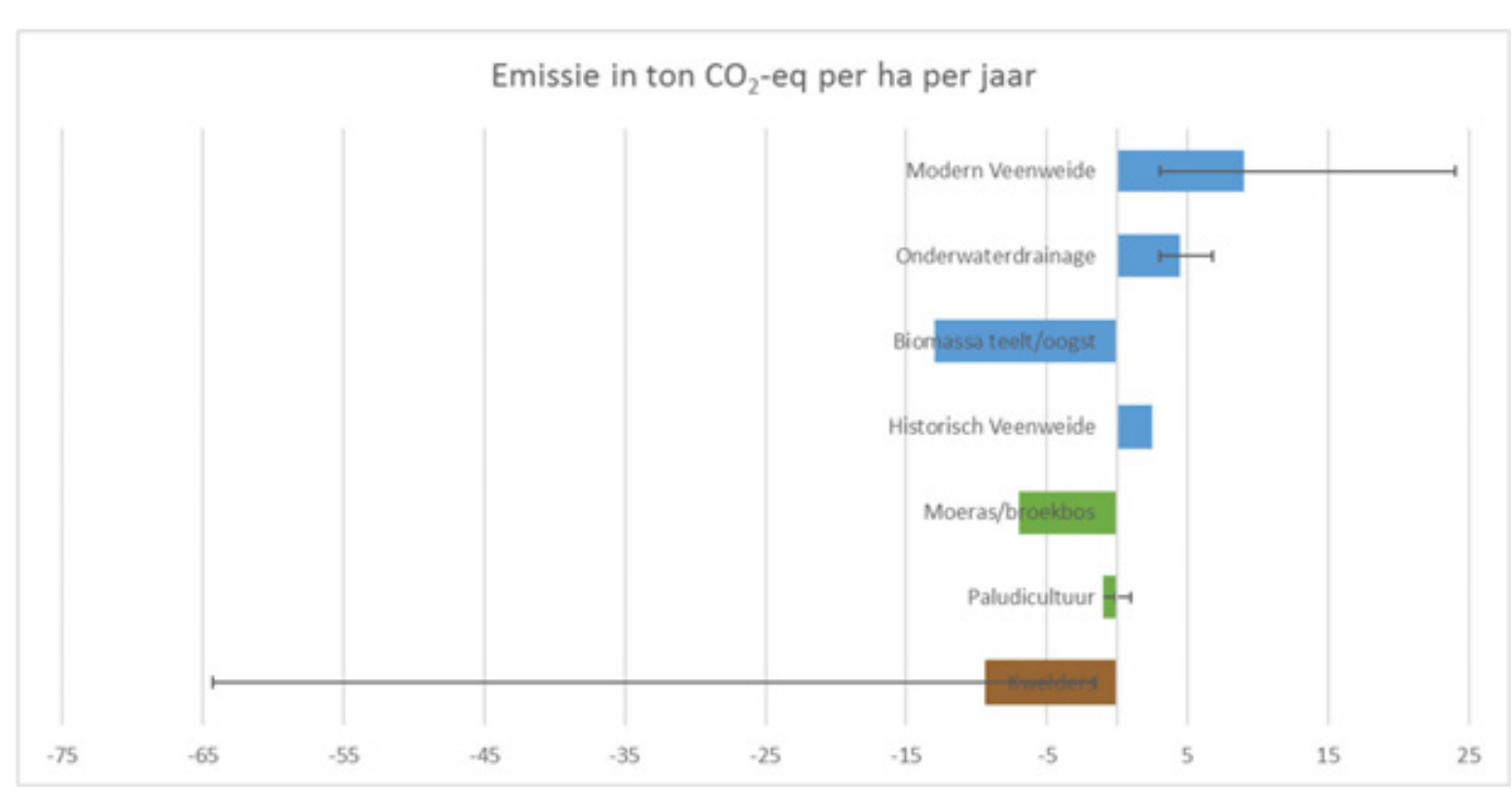

Figuur 5.3 Visuele weergave van de verschillende schattingen van gemiddelde emissiefactoren (in CO2-eq ha-1 $\mathrm{jr}^{-1}$ ) zoals gevonden in de literatuur: Biomassa, Moeras/broekbos en Historisch veenweide (van den Born et al. 2002), Modern veenweide (van de Riet et al. 2017; Van den Akker et al. 2018), Onderwaterdrainage (afgeleid uit (Vellinga et al. 2018), Paludi cultuur/natte teelt (van de Riet et al. 2017) en Kwelders (Tamis and Foekema 2015; Teunis and Didderen 2018).

Welke schattingen zijn er van land gebonden broeikasgasemissies op veengrond? In het Friese veenweidegebied $\left(54.500 \mathrm{ha}^{16}\right.$ ) wordt de totale $\mathrm{CO}_{2}$-equivalenten-emissie geschat op $\approx 1,3$ Mton jaar $^{-1}$ (Van den Akker et al. 2018). Dit is omgerekend 24 ton $\mathrm{CO}_{2}$-eq ha-1 jaar $^{-1}$.

In het westelijk veenweidegebied $\left(\approx 235.500 \mathrm{ha}^{17}\right)$ is de jaarlijkse emissie per hectare lager omdat het waterpeil hoger wordt gehouden (Kwakernaak and Verhoeven 2013; van den Born et al. 2016). De polder Oukoop is hier gelegen en veehouderij is daar de belangrijkste landgebruiker. In deze polder zijn broeikasgasemissies tussen 2008 en 2010 gemeten waaruit een gemiddelde emissiefactor van $\approx 12-16 \mathrm{CO}_{2}$-eq ha-1 jaar-1 $^{-1}$ is af te leiden (Kroon et al. 2012). De jaarlijkse gemiddelde emissie in de westelijke veenweidegebieden is op basis van het geschatte oppervlakte en deze emissiefactoren ongeveer 2,8-3,8 Mton $\mathrm{CO}_{2}$-eq. De totale jaarlijkse gemiddelde emissie voor het Friese en Hollandse veenweidegebied samen bedraagt dan opgeteld 4,1 tot 5,1 Mton jaar ${ }^{-1}$. Andere auteurs rapporteren schattingen van 4,2 Mton jaar ${ }^{-1}$ tot 7 Mton per jaar ${ }^{18}$ (Bromet and de Groot 2019; van den Akker and Hendriks 2014; Vertegaal et al. 2019).

\section{De nationale opgave}

De totale nationale broeikasgasemissie bedroeg 199 Mton $\mathrm{CO}_{2}$-eq jr ${ }^{-1}$ in 2017 (Ruyssenaars et al. 2019). Ten opzichte van 1990 heeft Nederland in 2017 circa 12\% broeikasgas emissiereductie gerealiseerd voor alle sectoren. Land gebonden broeikasgasemissies worden geregistreerd volgens de regels van $\mathrm{LULUCF}^{19}$. In de laatste nationale emissierapportage wordt gesteld dat de bijdrage van LULUCF ongeveer 5,6 Mton was (met name door oxidatie van veen) ${ }^{20}$.

\footnotetext{
${ }^{16}$ Dit is een optelsom van het bodemtype 'veen', 'veen met kleidek' en 'klei met veenondergrond'.

${ }^{17}$ In 2009 werd de totale oppervlakte veenweide in Nederland geschat op 290.000 ha (Kempen et al. 2009). Na aftrek van het oppervlakte van het Friese deel ( 54.500 ha) kom je op 235.500 ha areaal voor het westelijk veenweidegebied.

${ }^{18}$ Vermoedelijk is een jaarlijkse emissie van 7 Mton een overschatting omdat dit de totale land gebonden broeikasgasemissies (LULUCF) betreft (6,7 Mton in 2016 en 6,1 Mton in 1990). Dat zijn ook emissies buiten de veenweidegebieden, bijvoorbeeld ontbossing.

${ }^{19}$ LULUCF (land use, land use change, and forestry) is een term die UNFCCC gebruikt als verzamelterm voor de effecten van landgebruik op de broeikasgasbalans. Er bestaan aparte regels voor het rapporteren van dit type broeikasgasemissies.

${ }^{20}$ In eerdere emissierapportages werd gesproken over een jaarlijkse emissie van 6,7 Mton (Coenen et al. 2018) tot 7.5 Mton (Vertegaal et al. 2019) voor LULUCF. Deze inschattingen zijn naar beneden bijgesteld door een methodewijziging. In eerdere rapportages werd aangenomen dat het areaal veengrond niet is afgenomen sinds 1990 , terwijl dit wel zo was (Arets et al. 2019).
} 
Volgens het klimaatakkoord (versie 28 juni 2019) is in 2030 een emissiereductie mogelijk van 1,0 Mton $\mathrm{CO}_{2}$-eq jr ${ }^{-1}$ van land gebonden broeikassen door voornamelijk maatregelen bij landbouwbedrijven in veenweidegebieden. Voor 'bomen, bos en natuur' moet het afgesproken

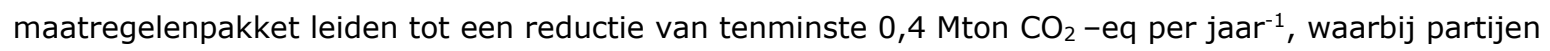
streven om de emissiereductie te vergroten tot 0,8 Mton jaar $^{-1}$ in 2030 . Deze ambitie is vastgesteld nadat in een eerdere analyse was geconcludeerd dat het concept-maatregelenpakket onvoldoende zekerheid biedt op het halen van de emissiereductie (Hekkenberg 2019). Het beoogde $\mathrm{CO}_{2}$-resultaat wordt voor ongeveer de helft gerealiseerd door uitbreiding en ander beheer van bomen/bos en voor de andere helft door herstel en uitbreiding van 'natte natuur', zoals venen en moerassen.

Inschatten van mogelijke koolstof-sink-potenties van natuurlijke klimaatbuffers Het vastleggen van broeikasgassen was niet een origineel doel van de eerste natuurlijke klimaatbuffers. Om toch naar dit aspect te kunnen kijken zijn er hypotheses geformuleerd voor een viertal klimaatbufferprojecten over de realiseerbare jaarlijkse broeikasgasreductie (kton), gebaseerd op de emissiefactoren en de oppervlakte van de klimaatbuffer, gecorrigeerd voor aan-/afwezigheid van veen (figuur 5.2) en de mate van drooglegging in de nul-situatie (tabel 5.5).

Tabel 5.5 Mate van drooglegging voor en na uitvoering van de vier voorbeeldklimaatbuffers.

\begin{tabular}{|c|c|c|c|}
\hline Klimaatbuffer & Bodem $^{21}$ & Hydrologie (voor) & Hydrologie (na) \\
\hline Hunze & $\begin{array}{l}\text { De projectgebieden liggen op } \\
\text { veen, moerige grond en zand. }\end{array}$ & $\begin{array}{l}\text { Voor de uitvoering varieerden } \\
\text { het grondwater tussen } 0,60 \mathrm{~m} \\
-\mathrm{mv} \text { (winter) tot } 1,20 \mathrm{~m}-\mathrm{mv} \\
\text { in de zomer. }\end{array}$ & $\begin{array}{l}\text { De drooglegging kan afnemen } \\
\text { met } 0,55 \mathrm{~m} \text { in beide seizoenen } \\
\text { met de vernattingsmaatregelen } \\
\text { (Spoolder } 2013 \text { ). }\end{array}$ \\
\hline De Onlanden & $\begin{array}{l}\text { Het gebied ligt voornamelijk op } \\
\text { veen. }\end{array}$ & $\begin{array}{l}\text { Een tegennatuurlijk peil met } \\
\text { fluctuaties tussen } 0,25 \text { tot } \\
0,80 \mathrm{~m}-\mathrm{mv} \text { (Lievense } \\
\text { Ingenieurs 2018a). }\end{array}$ & $\begin{array}{l}\text { Natuurlijke dynamiek is hersteld } \\
\text { en het gebied is natter geworden } \\
\text { ten opzichte van de } \\
\text { uitgangsituatie. }\end{array}$ \\
\hline Ilperveld & $\begin{array}{l}\text { Het gebied ligt voornamelijk op } \\
\text { veen. }\end{array}$ & $\begin{array}{l}\text { Grasland in onderbemaling } \\
\text { met een grondwaterstand van } \\
\text { gemiddeld } 50 \mathrm{~cm} \text {-mv (van de } \\
\text { Riet et al. 2017). }\end{array}$ & $\begin{array}{l}\text { Ingericht als veenmosakker met } \\
\text { een waterstand van } 5 \mathrm{~cm}-\mathrm{mv} \text {. }\end{array}$ \\
\hline
\end{tabular}

Op basis van figuur 5.3 en de ingeschatte $\mathrm{CO}$-eq fluxen bij Friese veenweidegebieden met veehouderij (Van den Akker et al. 2018) is gekozen om bij het formuleren van hypotheses voor de koolstof-sink-potentie van de Hunze en De Onlanden aan te nemen dat een emissiereductie mogelijk is tot 0 (geen netto opname of uitstoot) waarbij, voorafgaand aan de vernatting, de emissies gemiddeld lagen tussen de 6 en 24 ton CO2-eq ha-1. In het geval van Ilperveld is gebruik gemaakt van gemeten reductie van broeikasgasemissies over een periode van drie jaar (van de Riet et al. 2017). Wanneer de gebieden netto broeikasgassen zouden opnemen dan ontstaat er ook een negatieve flux (opname) en is het verschil ten opzichte van de oorspronkelijke emissies groter dan respectievelijk 24 (Hunze, Onlanden) en $5 \mathrm{CO}_{2}$-eq ha-1 (Ilperveld).

Een onzekerheid bij deze geformuleerde hypotheses is de rol van methaan, waarvan de emissies kunnen toenemen bij vernatting waardoor de gerealiseerde extra $\mathrm{CO}_{2}$-vastlegging weer deels gereduceerd kan worden (Fritz et al. 2017). Er zijn veel minder meetgegevens over de methaanuitstoot onder verschillende hydrologische en bodemkundige condities. Om tot betere kengetallen te komen voor koolstofvastlegging zijn meerjarige metingen van $\mathrm{CO}_{2}, \mathrm{CH}_{4}$ en $\mathrm{N}_{2} \mathrm{O}$ nodig. In recent onderzoek is ook aangegeven dat het vaak aangenomen lineaire verband tussen grondwaterstanden en broeikasgasemissies niet altijd opgaat, en is aanbevolen om op zoek te gaan naar alternatieven zoals het bodemvochtgehalte (Hoogland et al. 2019).

\footnotetext{
${ }^{21}$ Gebaseerd op kwalitatief visueel expertoordeel van de bodemkaart.
} 
De hypotheses uit tabel 5.6 hebben een grote bandbreedte omdat gewerkt is met grove voorbeeldberekeningen. In het onderzoek voor de 'Klimaatenvelop 2019' worden deze verfijnd met een GIS-analyse waarbij onderscheid gemaakt wordt tussen veenkarakteristieken (dik veen, dun veen, moerig), verschillende hydrologische condities en aanwezige/gewenste vegetatietypes (Wösten et al. in voorbereiding).

Economische waarde van de koolstof-sink-functie van natuurlijke klimaatbuffers op veen Met klimaatbuffers zijn alleen $\mathrm{CO}_{2}$-rechten te genereren voor de vrije markt (GDNK, 2018), waarbij de maximale koolstofprijs in $2018 \mathrm{lag}$ rond $5 €$ ton $^{-1} \mathrm{CO}_{2}$-eq volgens een internationale inventarisatie (Hamrick and Gallant 2018). Deze waarde is gebruikt bij de waardebepaling (tabel 5.6). Onder deze prijsaanname liggen de potentiële financiële baten van koolstofvastlegging voor de landeigenaar tussen de 30-120 $€ \mathrm{ha}^{-1} \mathrm{jr}^{-1}$. Dit is een inschatting van de opbrengst waarin de transactiekosten voor het certificeren van carbon credits niet zijn meegenomen.

Tabel 5.6 Hypotheses over de koolstof-sink potentie en de waarde hiervan voor vier voorbeelden van natuurlijke klimaatbuffers op veengronden.

\begin{tabular}{|c|c|c|c|c|c|c|}
\hline Klimaatbuffer & $\begin{array}{l}\text { Oppervlak } \\
\text { (ha) }\end{array}$ & Veen? & Vernatting & $\begin{array}{l}\text { Min-max } \\
\triangle \text { ton } \mathrm{CO}^{-}- \\
\text {eq } \mathrm{ha}^{-1}\end{array}$ & $\begin{array}{l}\mathrm{CO} 2 \text {-eq- } \\
\text { emissie- } \\
\text { reductie } \\
\text { (ton } \mathrm{jr}^{-1} \text { ) }\end{array}$ & $\begin{array}{l}\text { Waarde } \triangle \mathrm{CO} 2 \mathrm{ha}^{-} \\
{ }^{1} \mathrm{jr}^{-1} \text { vrije markt } \\
\text { C5 } \text { ton }^{-1} \text { (2019) }\end{array}$ \\
\hline De Onlanden & 2500 & Grotendeels & Goed & $6-24$ & $\begin{array}{l}15.000- \\
60.000\end{array}$ & $30-120$ \\
\hline Hunze & 785 & Deels & Redelijk & $6-24$ & $1800-7500$ & $30-120$ \\
\hline Anserveld/Leisloot & 150 & Marginaal & Redelijk & Marginaal & Marginaal & \\
\hline
\end{tabular}

Bij een prijs van $25 €$ ton $^{-1} \mathrm{CO}_{2}$-eq of hoger ${ }^{22}$ kan de opbrengst per hectare toenemen tot $150-600 €$ $\mathrm{ha}^{-1} \mathrm{jr}^{-1}$ op de vrije markt. Dit is een toekomstscenario met een koolstofprijs vergelijkbaar met de huidige koolstofprijs binnen Emission Trading System (ETS 2019).

Binnen het Duitse 'MoorFutures'-programma zijn voor een natuurherstelproject in veen in NoordDuitsland (polder Kieve) de investeringskosten van de genomen hydrologische herstelmaatregelen omgeslagen naar de realiseerbare emissiereductie (Joosten et al. 2015). Hierbij werd geconcludeerd dat de investeringskosten in deze casus $€ 35$ per ton vermeden $\mathrm{CO}_{2}$-eq bedroegen. Het onderzoek stelt dat bij een toekomstige $\mathrm{CO}_{2}$-prijs tussen $€ 10$ tot $€ 70$ per ton vermeden $\mathrm{CO}_{2}$-eq dit type projecten, afhankelijk van de lokale situatie, met financiering uit carbon credits economisch rendabel uit te voeren zijn.

Wat is er bekend over koolstofvastlegging bij kwelders?

Het klimaatakkoord neemt 'blue carbon', $\mathrm{CO}_{2}$-vastlegging in kwelders, nog niet mee, voornamelijk omdat er nog onzekerheid is over verhouding van autochtoon en allochtoon ('ingevangen') koolstof. Voor een deel vangen kwelders organisch materiaal in dat van elders komt die anders op de zeebodem of rivierbodem zou neerslaan.

\footnotetext{
${ }^{22}$ Dit was in 2018 ongeveer de $\mathrm{CO}_{2}$-prijs binnen het Emission Trading System (ETS). Het ETS-systeem is niet van toepassing voor landgebruik zoals natuurbeheer. Op de vrije markt zijn er grote verschillen in $\mathrm{CO}_{2}$-prijs.
} 


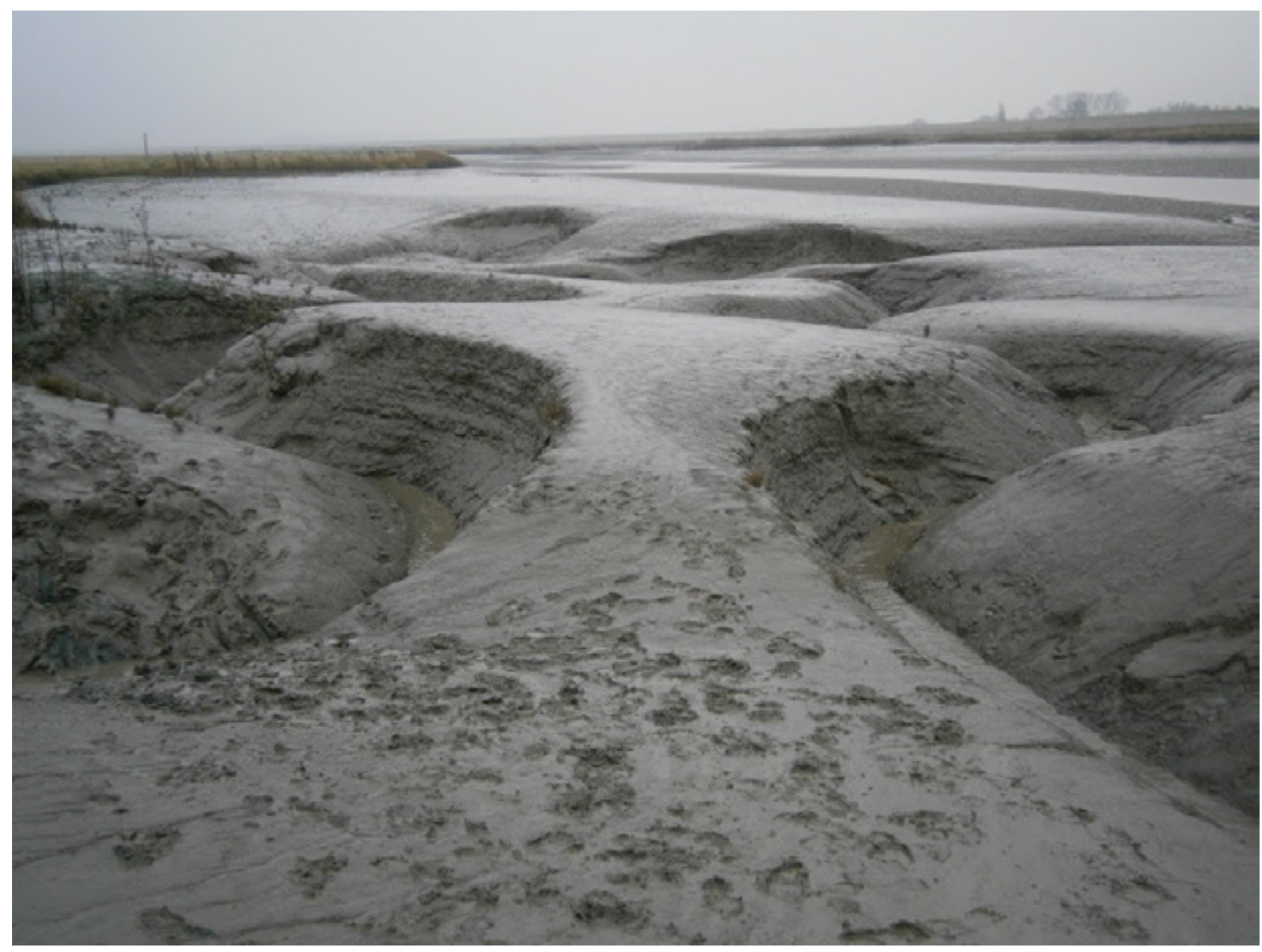

Verdronken Land van Saeftinge, ook dit gebied vertegenwoordigd een grote koolstofvoorraad (Foto: Paul Vertegaal, Natuurmonumenten).

Alleen de eerste categorie kan op conto van door kwelders vastgelegde $\mathrm{CO}_{2}$ komen. Zonder deze differentiatie aan te brengen is in eerder onderzoek ingeschat dat kwelders $(\approx 10.000$ ha) (Data ICT Dienst Rijkswaterstaat 2012) in Nederland jaarlijks netto $\approx-0,06$ à 0,1 Mton $\mathrm{CO}_{2}$-eq vastleggen gerekend met een emissiefactor van - 5,5 (Tamis and Foekema 2015) tot -9,3 ton $\mathrm{CO}_{2}$-eq ha-1 jaar ${ }^{-1}$ (Teunis and Didderen 2018). De vastleggingscapaciteit in zoute kwelders kan liggen tussen 0,7 en 63 ton CO2-eq ha-1 jaar $^{-1}$ op basis van wereldwijde gegevens (figuur 5.3). Tamis en Foekema (2015) schatten in dat de Nederlandse kwelders 5,5 tot 6,6 ton $\mathrm{CO}_{2}$-eq ha-1 $\mathrm{jr}^{-1}$ vastleggen.

De bestaande koolstofvoorraad onder Nederlandse kwelders is eerder ingeschat op 7 miljoen ton $\mathrm{CO}_{2}$ (Teunis and Didderen 2018), waarbij moet worden aangemerkt dat de toegepaste bemonstering in de laatste studie kan leiden tot een overschatting van de koolstofvoorraad in kwelders (Mueller et al. 2019). Er is meer onderzoek nodig om de koolstofvoorraad en koolstofvastleggingscapaciteit in de Nederlandse kwelders beter in te kunnen schatten.

\section{Ervaringen met koolstofvastlegging in rivierbos met klimaatbuffers}

De klimaatbuffer Ooijen-Wansum was de enige klimaatbuffer in het rivierengebied waarvoor, voor aanleg, een koolstofvastleggingsdoel was geformuleerd. Dit doel moest worden gerealiseerd met de aanleg van bos en moerasnatuur op minerale grond. In de kennisinventarisatie staat: "Door de ontwikkeling van moerasvegetatie en struweel aan de randen van de geul, zal in bescheiden mate $\mathrm{CO}_{2}$ worden vastgelegd." In hoofdstuk 8 wordt besproken welke meekoppelkansen er bestaan tussen waterbeheer en het klimaatakkoord in het rivierengebied. 


\subsection{Natuurlijke Spons}

\subsubsection{Inleiding}

In de definitie van de CNK houdt het type klimaatbuffer 'Natuurlijke Spons' water vast in bovenstrooms gelegen natuurgebieden. Dat kan in de haarvaten van het oppervlaktewatersysteem (sloten, beekjes), in (hoog)veengebieden, bossen, vochtige heide en doorstroommoerassen (CNK 2019). Het effect is buffering van hydrologische extremen: door het bovenstrooms vasthouden van water wordt zowel wateroverlast lager in het systeem voorkómen (in Nederland liggen daar vaak steden) en wordt water in de bodem geconserveerd, waardoor droogteperioden in de omgeving van de natuurlijk klimaatbuffer kunnen worden opgevangen. Er zijn vier van dit type klimaatbuffers in de eerste fase gestart (tabel 5.7), en na 2012 nog meer (figuur 3.1). Ook bij de inrichting van klimaatbuffers van het type Groenblauwe Ruimte (zoals De Onlanden, Regge) is waterberging gecombineerd met maatregelen gericht op het vergroten van het watervasthoudend vermogen van bodem en watersysteem (hoofdstuk 5.2).

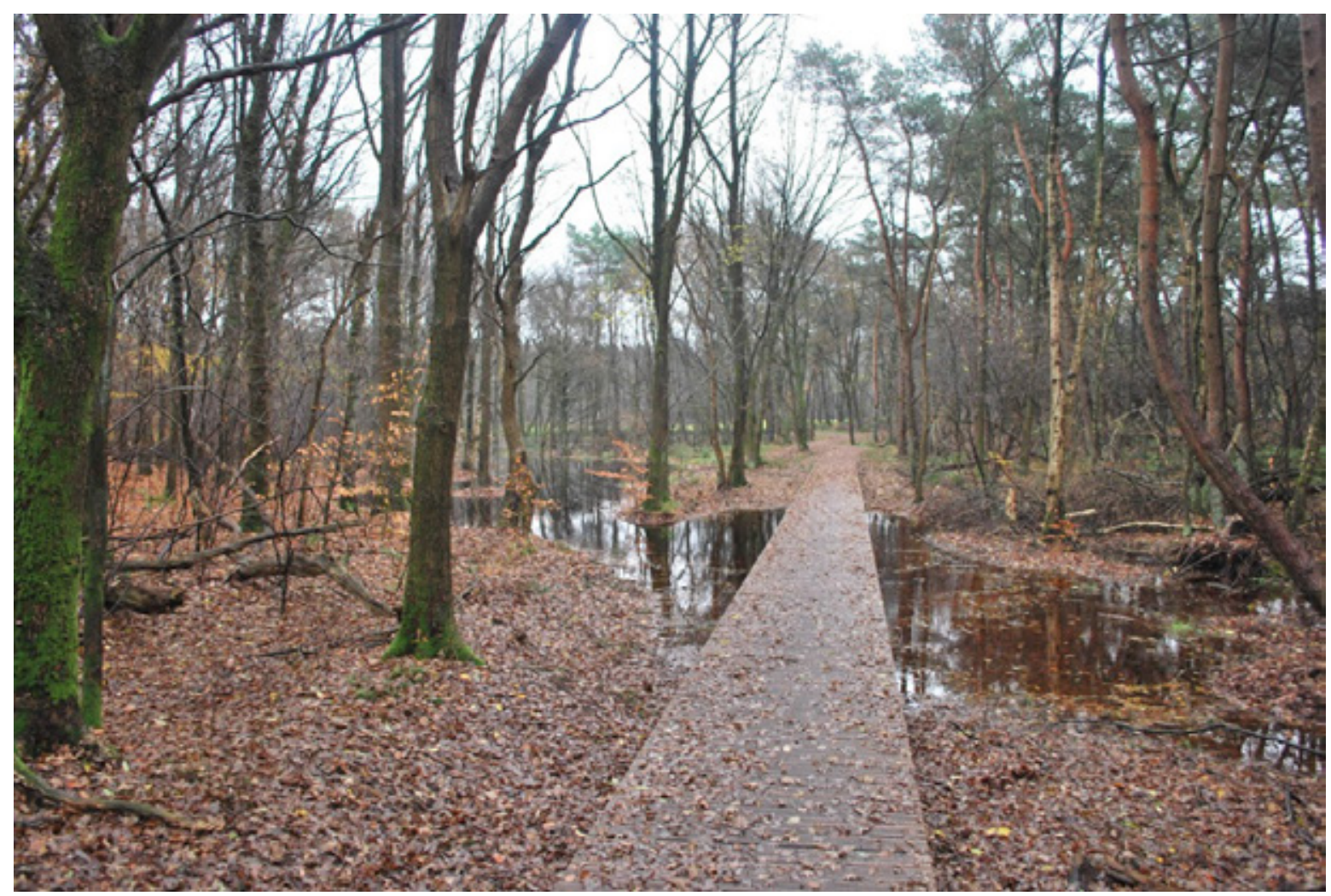

De Natuurlijke Spons in werking bij het Dwingelderveld (Foto: Paul Vertegaal, Natuurmonumenten). 
Tabel 5.7 Overzicht van klimaatbuffers van het type Natuurlijke Spons die gestart zijn tussen 2008 en 2012 en de Leuvenumse beek (gestart in 2014).

\begin{tabular}{|c|c|}
\hline Naam & Status \\
\hline Anserveld/Leisloot & e sectie 4.7 \\
\hline Weerterbos (CNK 2019) & $\begin{array}{l}\text { Het Weerterbos, gelegen op afgegraven hoogveengebied, bestaat uit loofbossen, vennen en } \\
\text { kleine heidegebieden en is onderdeel van het Grenspark Kempen-Broek. Er zijn vennen en } \\
\text { moerasbossen hersteld en daarmee het vermogen om water langer vast te houden. Genomen } \\
\text { maatregelen: ontwateringsloten dempen/minder diep maken, inlaatwater uit } \\
\text { landbouwgebieden omleiden, aanleg doorstroommoerassen en de uitbreiding van natuurgebied } \\
\text { (13 ha). Dankzij de maatregelen in het Weerterbos is er minder risico op wateroverlast in Den } \\
\text { Bosch en Eindhoven. Het landschap is heterogener geworden met kansen voor watervogels en } \\
\text { edelherten. }\end{array}$ \\
\hline $\begin{array}{l}\text { Kempen-Broek (Ark } \\
\text { Natuurontwikkeling 2014) }\end{array}$ & $\begin{array}{l}\text { Tussen } 2010 \text { en } 2014 \text { zijn doorstroommoerassen hersteld in combinatie met aanleg nieuwe } \\
\text { natuur, waterberging en recreatie. Met ruilverkaveling hebben boeren marginale } \\
\text { landbouwgrond kunnen inruilen voor gronden die minder droogtegevoelig zijn (mede door de } \\
\text { herstelde bufferwerking van naastgelegen natuur) en zijn natuurgebieden aaneengeschakeld. } \\
\text { Op dit moment (2019) wordt gewerkt aan maatregelen om de waterkwaliteit verder te } \\
\text { verbeteren en het afplaggen van stikstofrijke grond (PAS-maatregel). Er is herstel } \\
\text { waargenomen van natte natuur, zoals de terugkeer van zeldzame flora (bijvoorbeeld } \\
\text { egelboterbloem). Men verwacht ook dat dit, op termijn, herstel van watergebonden dieren kan } \\
\text { betekenen. Natuurmonumenten heeft in } 2018 \text { het initiatief genomen voor een verder } \\
\text { opschaling van deze natuurlijke klimaatbuffer. }\end{array}$ \\
\hline $\begin{array}{l}\text { Schoonwatervallei } \\
\text { Castricum }\end{array}$ & $\begin{array}{l}\text { In de polders bij Castricum en Limmen is schoon kwelwater uit de duinen beschikbaar } \\
\text { gemaakt voor natuur en is een bufferzone tussen de drinkwaterwinning en de landbouw } \\
\text { gerealiseerd. Er zijn maatregelen genomen om water langer vast te houden, er is extra } \\
\text { waterberging gerealiseerd en er is } 3 \text { kilometer natuurvriendelijke oever aangelegd. Landschap } \\
\text { Noord-Holland was trekker van dit gebiedsontwikkelingsproject. Het waterschap werkt samen } \\
\text { met agrariërs om de belasting van het oppervlaktewater met bestrijdingsmiddelen terug te } \\
\text { dringen (van Hattum et al. 2015). Er is na } 2014 \text { een vervolgfase opgestart onder leiding van } \\
\text { het waterschap gericht op uitbreiding tot aan het Alkmaardermeer, maar opschaling is } \\
\text { moeilijk. LTO heeft aangegeven dat de jonge boeren in de Groot Limmerpolder investeringen } \\
\text { hebben gedaan en hun land niet willen uitruilen of verkopen (Lievense Ingenieurs 2018c). }\end{array}$ \\
\hline Leuvenumse beek & $\begin{array}{l}\text { In de Leuvenumse beek wordt vanaf } 2014 \text { het suppleren van zand als beekherstel- maatregel } \\
\text { toegepast door waterschap Vallei en Veluwe en Natuurmonumenten. Uit de monitoring blijkt } \\
\text { dat het beekmoeras bijdraagt aan de totale biodiversiteit van het stroomgebied. Er zijn een } \\
\text { aantal plant- en diersoorten gevonden die niet op de andere locaties zijn aangetroffen. Het } \\
\text { projectgebied is drie jaar na de suppleties nog volop in ontwikkeling. Hoe 'extremere' } \\
\text { klimaatjaren zoals } 2018 \text { doorwerken op de langere termijn in zowel hydromorfologisch als } \\
\text { ecologisch opzicht moet de komende jaren blijken (Verdonschot and Verdonschot 2019). }\end{array}$ \\
\hline
\end{tabular}

\subsubsection{Bijdragen aan doelen klimaat, natuur en economie}

Voor het klimaatbuffertype 'Natuurlijke Spons' wordt per evaluatiecriterium omschreven welke generieke leerpunten te benoemen zijn. Hierbij is aanvullende informatie verzameld binnen de deskstudie.

\section{Klimaatadaptatie}

Ecologische veldwaarnemingen van de natuurterreinbeheerders in natuurlijke klimaatbuffers zoals Anserveld/Leisloot (sectie 4.7), De Onlanden ${ }^{23}$ (sectie 4.2), Leuvenumse beek (sectie 5.4.1) en Schoonwatervallei Castricum (sectie 5.4.1) tonen aan dat de hydrologische herstelmaatregelen lokaal hebben geleid dat verdrogingseffecten verminderd zijn. Grondwaterstanden worden ook systematisch gemeten op deze locaties, maar het is vaak moeilijk om het ecohydrologisch effect van individuele interventies, los van andere drukfactoren, op wetenschappelijke wijze vast te stellen. De periodieke evaluaties van het PBL (figuur 5.4) illustreren ook dat het moeilijk is om op nationaal niveau positieve

\footnotetext{
${ }^{23}$ De Onlanden is niet ingedeeld onder het klimaatbuffertype 'Natuurlijke Spons', maar de hydrologische herstelmaatregelen in dit gebied dragen ook bij aan het verbeteren van het watervasthoudend vermogen van de bodem (maar niet het hoofddoel).
} 
ecologische effecten vast te stellen van antiverdrogingsbeleid. Daarnaast spelen ook de volgende zaken mee:

- Het uitrollen van de herstelmaatregelen kost meer tijd dan vooraf gedacht, bijvoorbeeld door vertraagde grondverwerving (van Egmond et al. 2018). De klimaatbuffer Kempen-Broek is een positieve uitzondering op deze regel omdat grondverwerving en uitruil tussen agrariërs en natuurontwikkelaars hier dankzij vrijwillige kavelruil sneller is verlopen.

- Het effect van hydrologische herstelmaatregelen op wijzigingen in de gemiddelde grondwaterstanden zijn pas statistisch vast te stellen na meerdere jaren. Ecologische effecten (terugkeer vochtminnende soorten) kunnen een sneller of langzamer een response laten zien op de gewijzigde grondwaterstanden.

- Het is mogelijk dat de watervraag in het omliggende gebied van de hydrologische herstelmaatregel tegelijkertijd ook is toegenomen door economische ontwikkeling en klimaatverandering.

\section{Verandering van gemiddelde voorjaarsgrondwaterstand}

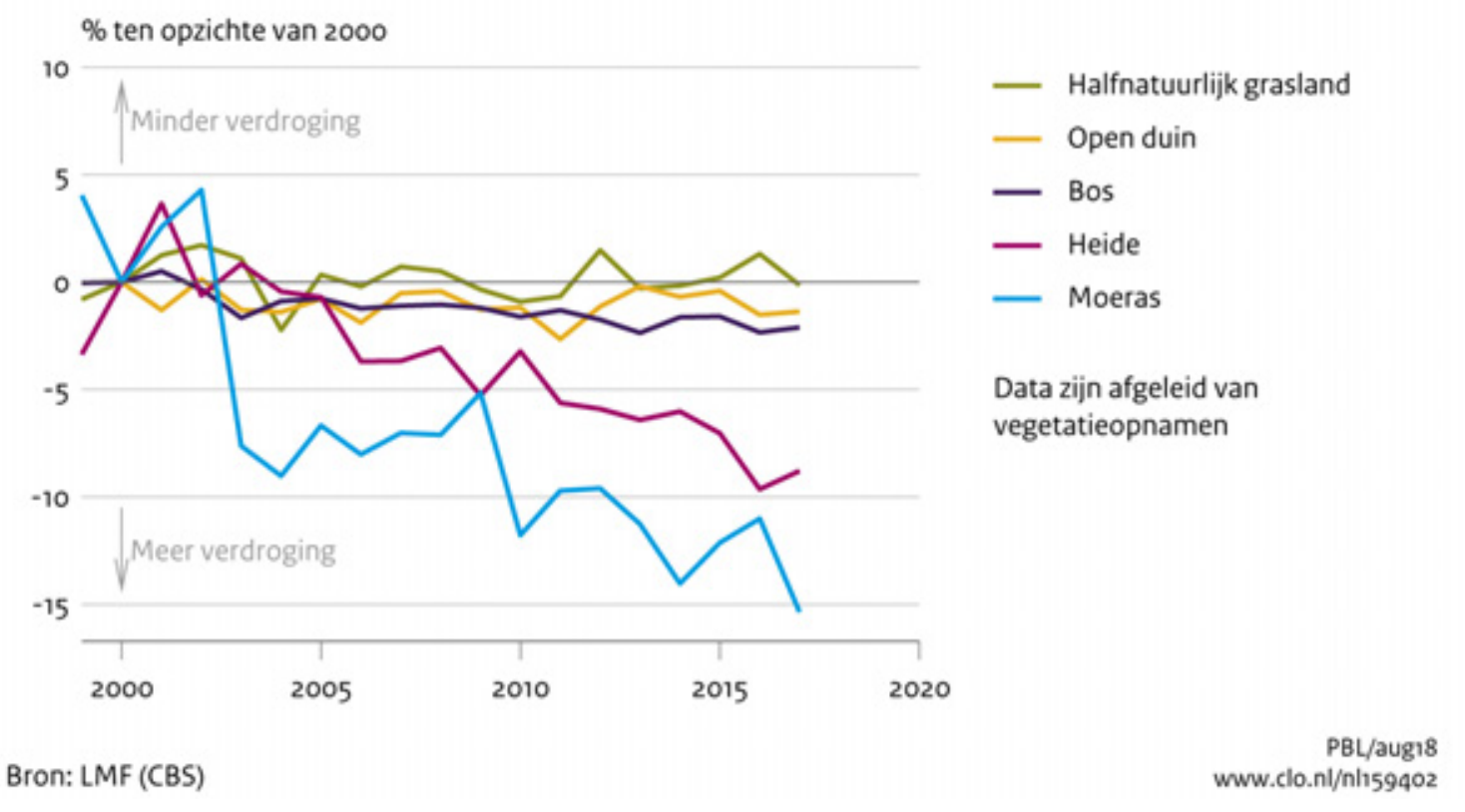

Figuur 5.4 Trend in de gemiddelde voorjaarsgrondwaterstand in verdrogingsgevoelige natuurgebieden (PBL 2017).

\section{Natuur}

Wanneer de spons is gerealiseerd in 2008-2014 (tabel 5.7) om bepaalde natuurdoelen te behalen blijkt deze maatregel doorgaans succesvol omdat verdroging van de natuur vaak het grootste knelpunt was dat met hydrologische herstelmaatregelen aangepakt kon worden. Bij projecten zoals de Leuvenumse beek leidt de spons bovendien tot een grotere diversiteit in habitat en soorten. Het is moeilijker om effecten aan te tonen in natuurgebieden waar bijvoorbeeld stikstofdepositie ook een groot knelpunt is naast verdroging (voorbeeld Kempenbroek).

Uit de beschikbare informatie van de twintig klimaatbuffers uit de eerste fase (alle typen) valt af te leiden dat er circa 20.000 hectare natuur in Nederland is ingericht met het klimaatbuffer-principe, inclusief de natuurgebieden die meeprofiteren van de herstelmaatregelen. Deze 20.000 hectare is $4 \%$ van alle natuurterreinen van Staatsbosbeheer, Natuurmonumenten en de Landschappen. Hierbij is circa 2000 hectare nieuwe natuur gerealiseerd in de periode 2008-2012. Er is daarnaast nog circa 5000 hectare terrein met het klimaatbufferprincipe ingericht waarvan met de beschikbare informatie niet was te herleiden wie de eigenaar was. Soms is ook landbouwgebied met een natuurvriendelijke inrichting of waterbergingsfunctie gerealiseerd. De arealen van de klimaatbuffers in de Rijkswateren zijn ook niet meegenomen. Een belangrijke onbeantwoorde vraag is: Hoeveel procent van de droogtegevoelige natuurterreinen zou moeten worden aangepakt met hydrologische 
herstelmaatregelen die in de klimaatbuffers zijn uitgevoerd, om de trend uit figuur 5.4 te keren? En wat zou herinrichting van omliggende landbouwgebieden daarbij kunnen betekenen?

\section{Economie}

Dit type klimaatbufferprojecten is mede gerealiseerd omdat nabijgelegen landbouw-, recreatie- en drinkwaterbedrijven vooraf ook economisch profijt verwachten van het herstel van de bufferwerking van naastgelegen natuurgebieden (bijvoorbeeld Kempenbroek). Er zijn geen studies gevonden die dit verwachte economisch profijt voor deze klimaatbufferprojecten (tabel 5.7) ook hebben uitgedrukt in baten, kostenbesparing of besparing van arbeid.

Uit belevingsonderzoek van NIPO onder akkerbouwers uit Zeeland is af te leiden dat Zeeuwse akkerbouwers 500 tot 750 euro per hectare opbrengstderving toeschrijven aan watertekort in zeer droge zomers (Veraart et al. 2017). Dat zou een concept-vuistregel kunnen zijn voor het effect van de sponswerking van natuur voor de landbouw. Dit moet wel nader worden onderzocht want ook een klimaatbuffer zal niet alle toegeschreven opbrengstderving door watertekort kunnen compenseren en de opbrengstreductie in een droge zomer zal verschillen per type landbouwbedrijf (gewaskeuze, bodemsoort).

Naast opbrengstderving spelen kosten van beregening een rol. Het uitvoeren van een beregeningsbeurt is voor een akkerbouwer zeer arbeidsintensief. Met andere woorden: het uitstellen of uitsparen van twee of drie beregeningsbeurten door de aanwezigheid van een natuurlijke klimaatbuffer is, in bedrijfseconomische zin, voor een akkerbouwer wellicht nog belangrijker dan het voorkomen van opbrengstderving (Oude Essink et al. 2019). In een matig droge zomer is het economisch effect van de sponswerking van een natuurgebied voor omliggende agrarische bedrijven waarschijnlijk groter dan in een extreem droge zomer. In een matig droge zomer is het uitsparen van twee/drie beregeningsbeurten namelijk al voldoende om droogteschade te voorkomen, terwijl in een extreem droge zomer er uiteindelijk toch wel beregend moet worden en er onvermijdelijke schade is.

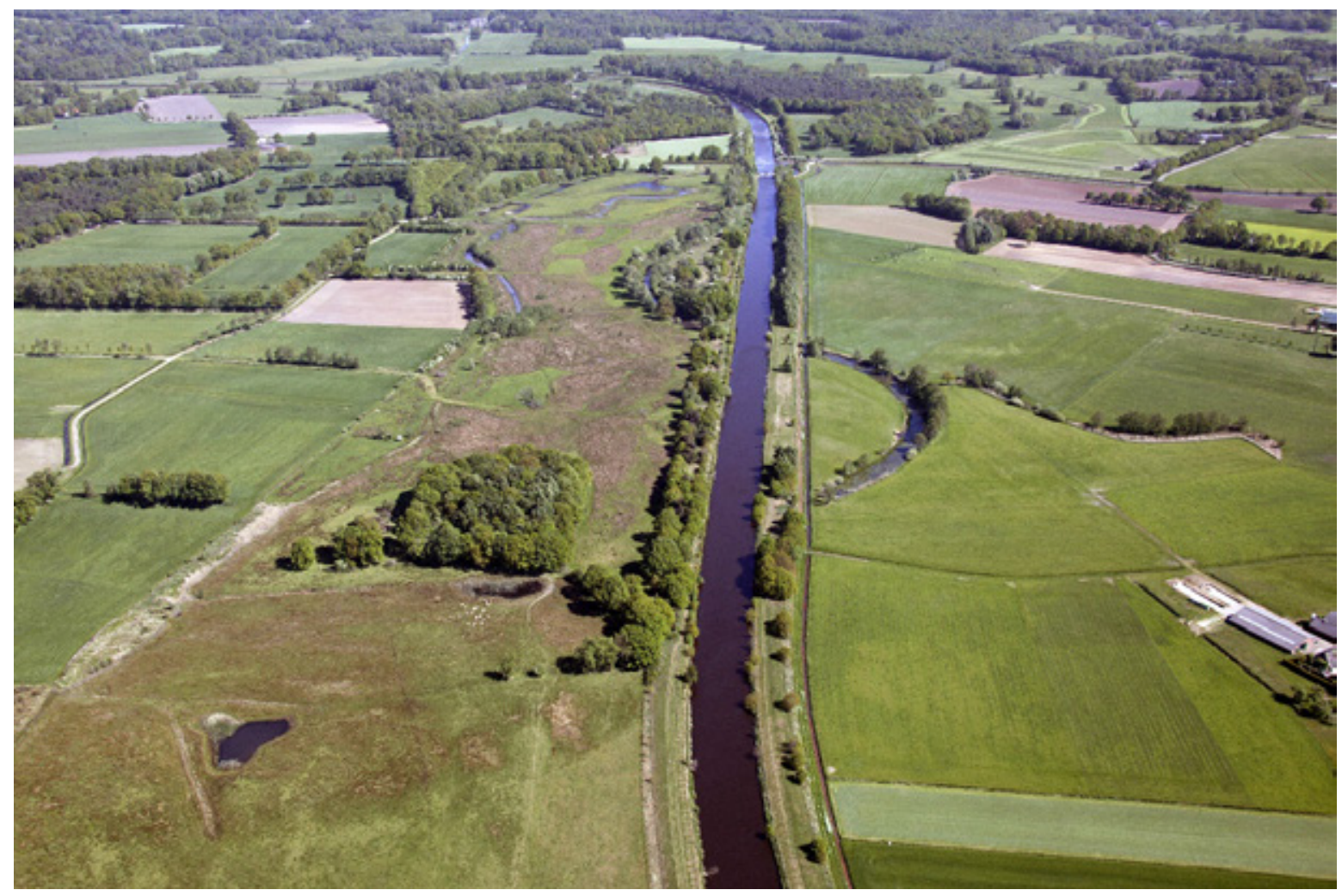

Luchtfoto van de Regge met aan linkerzijde natuur en aan de rechterzijde landbouwgrond (Foto:

Waterschap Regge en Dinkel). Tijdens het Deltacongres (2019) werd uitgelegd de grondwaterstanden in dit gebied verhoogd zijn.

Zie https://www.youtube.com/watch?v=FThYDj6CvYk 


\section{$5.4 \quad$ Levende Kust en Biobouwers}

\subsubsection{Inleiding}

De natuurlijke klimaatbuffers 'Levende Kust' en 'Biobouwers' zijn in de evaluatie samengenomen omdat ze regelmatig overlappen. De vraag over bijdragen aan klimaat, natuur en economische doelen kan voor beide vaak beantwoord worden met publicaties uit het domein van het onderzoeksprogramma 'Building with Nature' van stichting EcoShape.

De CNK omschrijft natuurlijke klimaatbuffers van het type 'Levende Kust' als projecten die bijdragen aan de bescherming tegen hoogwater van kust- en deltawateren. Dit type klimaatbuffer versterkt de primaire waterkering door een natuurlijke inrichting van de kust, zoals duinvorming met vrij stuivend zand en natuurlijke kwelders die golven remmen. De natuurwaarde van het gebied stijgt hierdoor, omdat zo'n klimaatbuffer planten, vogels en onderwaternatuur die er van oorsprong thuis horen, biedt wat ze nodig hebben (CNK 2019). De natuurlijke klimaatbuffer van het type 'biobouwers' bestaat uit levende golfdempers en kan letterlijk meegroeien met de zee. Dit draagt bij aan kust- en oeverversterking (CNK 2019). Box 5.1 omschrijft hoe anderen biobouwers omschrijven.

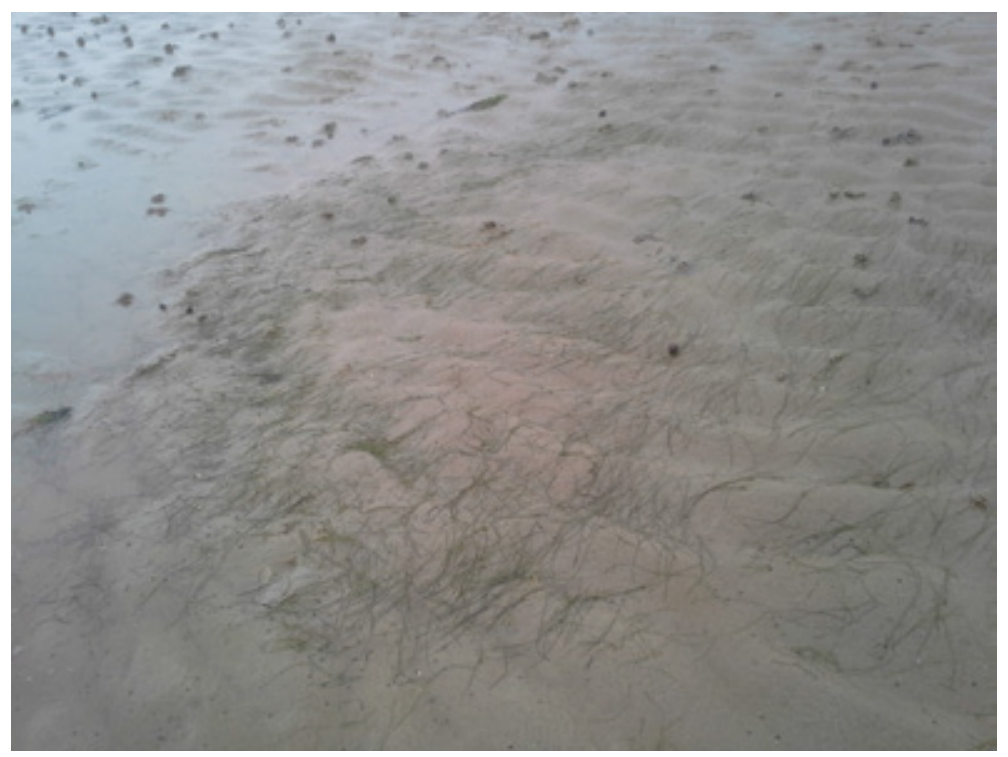

Klein zeegras bij de Oesterdam (Foto: Jeroen Veraart, 2019).

Box 5.1. Wat zijn biobouwers? (Tangelder et al. 2014)

Biobouwers worden gedefinieerd als: "planten, dieren of andere organismen die direct of indirect effect hebben op de beschikbaarheid van hulpbronnen voor andere soorten door het veroorzaken van fysische veranderingen in levend of dood materiaal." (Jones et al. 1994; Jones et al. 1997) De term biobouwers is een vertaling van de oorspronkelijke Engelse term 'ecosystem engineers', die eigenlijk beter aangeeft wat die organismen doen: het zijn organismen die door hun aanwezigheid of activiteiten, direct dan wel indirect, hun omgeving beïnvloeden. Daarmee veranderen, behouden, of vernietigen ze het habitat voor zichzelf en andere organismen, of ze creëren juist nieuw habitat. Denk daarbij bijvoorbeeld aan de invloed die rif vormende schelpdieren, zoals oesters, kunnen hebben op golfdemping en sedimentatie waarbij ze fungeren als habitat voor andere organismen. Er zijn ook biobouwers die juist een destabiliserend effect of het systeem hebben, zoals wadpieren (Arenicola marina) die het sediment omwoelen (Reed et al. 2018; Van Weesenbeeck et al. 2007). Voorbeelden van kustecosystemen die ontstaan als gevolg van dergelijke terugkoppelingen zijn: zeegrasvelden (van der Heide et al. 2007; van der Heide et al. 2011), mosselbedden (Van de Koppel et al. 2008), kwelders en duinen. Door hun eigen omgeving te veranderen kunnen biobouwers zichzelf tegen verschillende stressoren beschermen (bijvoorbeeld golfstress, predatie, zuurstofloosheid, etc.), maar ook andere soorten kunnen profiteren en zijn soms zelfs afhankelijk van deze gemodificeerde ecosystemen. 
Tabel 5.8 geeft een overzicht van de status van de klimaatbufferprojecten van deze twee types die gerealiseerd zijn tussen 2008 en 2014, aangevuld met enkele projecten die na 2014 zijn gestart van.

Tabel 5.8 Overzicht klimaatbufferprojecten van het type Biobouwer en Levende Kust (2008-2014).

\begin{tabular}{|c|c|}
\hline Projectnaam & Toelichting status \\
\hline Feugelpôlle (Biobouwer) & $\begin{array}{l}\text { De Feugelpôlle is een kwelder aan de zuidwestkust van Ameland die in het verleden } \\
\text { erosiegevoelig bleek. Tussen } 2007 \text { en } 2012 \text { was het oppervlakte afgenomen van } 25 \\
\text { tot } 5 \text { hectare (Veenendaal and Fens 2012). Er zijn in } 2012 \text { kleischelpen tegen de } \\
\text { kwelderrand aangebracht, er zijn rijshouten dammen geplaatst en er is substraat } \\
\text { geplaatst waarop jonge mosseltjes zich kunnen vestigen. Het project is uitgevoerd } \\
\text { door een breed consortium o.l.v. Staatsbosbeheer. Het project wordt tot } 2022 \\
\text { gemonitord door Rijkswaterstaat. }\end{array}$ \\
\hline Zeegrasherstel (Biobouwer) & $\begin{array}{l}\text { Groot Zeegras (Zostera marina) wordt sinds } 2011 \text { regelmatig ingezaaid. Het } \\
\text { resultaat is wisselend door o.a. beperkte kiemkracht (Van Duren and van Katwijk } \\
\text { 2015). Desondanks is wel veel ervaring opgedaan waar nieuwe projecten op } \\
\text { voortbouwen. Het project Zeegrasherstel maakt een doorstart in } 2019 \text { in het } \\
\text { project 'Sleutelen aan zeegrasherstel' om in } 2021 \text { uitsluitsel te kunnen geven of } \\
\text { grootschalig zeegrasherstel op droogvallende wadplaten zinvol is (Rijkswaterstaat } \\
\text { et al. 2019). Uit onderzoek van NIOZ en Natuurmonumenten nabij Griend blijkt dat } \\
\text { de kans op een succesvolle herintroductie van zeegras aanmerkelijk groter is } \\
\text { wanneer de ingezaaide velden op droogvallende platen vochtig gehouden worden } \\
\text { met zeegrasmatten (Wijnja 2019). }\end{array}$ \\
\hline Oesterdam (Biobouwer) & $\begin{array}{l}\text { Er is aangetoond dat met zandsuppleties periodiek onderhoud van de kering } \\
\text { daadwerkelijk uitgesteld kan worden (Walles et al. 2018). Zie sectie } 4.8\end{array}$ \\
\hline Punt van Voorne (Levende Kust) & $\begin{array}{l}\text { Het natuurdoel van deze klimaatbuffer was herstel van } 15 \text { ha habitattype witte } \\
\text { duinen (H2120) in de Groene Punt. De maatregel is genomen in } 2010 \text {. In } 2012 \text { en } \\
2017 \text { was nog geen sprake van volledig herstel van dit habitattype (Provincie Zuid- } \\
\text { Holland 2017). Er zijn wel positieve ecologische effecten. Onnatuurlijk } \\
\text { duindoornstruweel lijkt niet terug te keren en pioniersvegetatie is tot ontwikkeling } \\
\text { gekomen (o.a. zeeraket en loogkruid), maar zet niet door. De toegenomen } \\
\text { dynamiek biedt kansen voor de biodiversiteit (Poot and Oosterom } \\
\text { 2014).Waterschap Hollandse Delta doet de monitoring van de hoogteligging } \\
\text { (strand \& duin) en grondwaterstand. Natuurterreinbeheerders volgen de } \\
\text { ecologische ontwikkeling. }\end{array}$ \\
\hline
\end{tabular}

Friese IJsselmeerkust (Levende Kust) Dit is een bijzondere 'Levende Kust'-klimaatbuffer omdat dit geen zeekust is. Het gesuppleerde zand in Workum en Oudemirdum verspreidt zich, maar er is geen kustversterking door aanzanding waargenomen (Wiersma et al. 2018). Ervaringen hiervan worden meegenomen bij de uitwerking van PAGW-maatregel 'Friese IJsselmeerkust' (It Fryske Gea 2019; van Nieuwenhuizen and Schouten 2019).

Hondsbossche en Pettemer Deze klimaatbuffer is gerealiseerd in 2015 en het besluitvormingsproces hierover is Zeewering (Levende Kust) eerder geëvalueerd door het PBL (Smit et al. 2014), de CNK (Schepers et al. 2014) en WUR (van Hattum et al. 2015). Uit de eerste monitoringsresultaten uit 2017 zijn nog geen harde conclusies te trekken over de ontwikkeling van natuur ín de nieuwe duinen en kustzone, effecten zijn pas op termijn te verwachten (van der Wel 2017). Zoals vooraf ingecalculeerd zijn mossels en vogelsoorten die profiteerden vaneen harde zeewering lokaal verdwenen (van der Wel 2017). Achter de zeewering zijn speciale eilandjes gemaakt voor broedvogels in natuurgebied de Putten en de Harger- en Pettemerpolder die nu al als broedplaats worden gebruikt door zeldzame of bedreigde soorten, zoals de grote stern (zomer 2019). De verbrakking van de Harger en Pettemerpolder was een discussiepunt en is uiteindelijk niet uitgevoerd. Het waterschap ziet de realisatie als een voorbeeld van succesvol omgevingsmanagement (van Hattum et al. 2015). Wel zijn er bij Hoogheemraadschap Hollands-Noorderkwartier (HHNK) en Rijkswaterstaat onzekerheden over de noodzakelijke frequentie van onderhoudsmatige zandsuppleties. Men verwacht dat dit vaker nodig is dan vooraf aangenomen.

Roggenplaat (Levende Kust) (KB-project van na 2014) De maatregel maakt onderdeel uit van de Programmatische Aanpak Grote Wateren (PAGW). De uitvoering is in voorbereiding, de financiering is geregeld (Veraart et al. 2019). 
Projectnaam

Zachte dijkversterking Texel

(Levende Kust)
Toelichting status

Ter hoogte van de Prins Hendrikpolder zou een gewone dijkversterking gevolgen hebben voor de landbouw en binnendijkse natuur. Na interventie van de deltacommissaris en landsadvocaat (checken risico's) is gekozen om aan de buitenzijde van de dijk een duinenrij aan te leggen met daarvoor schorren en slikken. Dit dijktraject is omgedoopt tot de 'Prins Hendrikzanddijk' (HHNK 2019). De zandige oplossing is in 2019 gerealiseerd.

Marconi-project

Met het project Marconi wil de gemeente Delfszijl het stadscentrum weer verbinden met de Waddenzee. Om het strand te kunnen vergroten wordt de zeedijk landinwaarts verlegd en de nieuwe zeedijk krijgt een multifunctionele inrichting het wordt een fiets- en wandelboulevard met verschillende recreatieve voorzieningen (Programma Rijke Waddenzee 2018; Provincie Groningen and Ministerie van Infrastructuur en Milieu 2016). Voor het waterschap was een neutrale grondverzetbalans een succesfactor. Langs de Schermdijk en de Handelskade Oost wordt een kwelderlandschap (Groninger Landschap) en een broedvogeleiland aangelegd (Rijkswaterstaat). Stichting EcoShape heeft geholpen met onderzoek.

Brede groene dijk Dollard
Dit is een pilot in uitvoering waarbij het waterschap Hunze en Aa's heeft gekozen voor dijkversterking met een flauw talud, voorzien van een dikke laag klei en begroeid met gras in plaats van asfalt. De klei die hiervoor nodig is $\left(1,7\right.$ miljoen $\mathrm{m}^{3}$ klei) wordt gewonnen in de buitendijkse kwelder, polder Breebaart en door kleirijping van zout baggerslib uit de haven van Delfszijl (Hunze en Aa 2018). De komende jaren zijn nodig om de klei te laten rijpen (2018-2021). Pas daarna kan $1 \mathrm{~km}$ dijk worden aangepast die vervolgens in de periode 2021-2024 getest en gemonitord wordt. Voor Natura 2000 is het van belang dat het oppervlakte van de kwelder niet afneemt bij het afgraven omdat er een instandhoudingsdoel is opgenomen voor kwelders (H1310A en H1330A) (Baptist and Geelhoed 2016). De inzet is om de natuurkwaliteit van de huidige kwelder te verbeteren door het herstel van oude kreken patronen en het verjongen van de vegetatie. De pilot wordt uitgevoerd in samenwerking o.a. Groninger Landschap, provincie Groningen en stichting EcoShape. Wanneer het kleirijpingsproces economisch rendabel kan worden uitgevoerd biedt dit kansen voor economische ontwikkeling.

\subsubsection{Bijdragen aan doelen klimaat, natuur en economie}

\section{Klimaat}

Een belangrijke kennisvraag is hoe lang biobouwers (kwelders, zeegras) en zandige oplossingen (o.a. dynamische duinen, zandsuppleties) effectief kunnen blijven en meegroeien met de zeespiegelstijging (Wang et al. 2018). Belangrijk is ook om in beeld te krijgen op welke plekken natuurlijke oplossingen het meeste effectief zijn, gegeven het feit dat de Nederlandse delta netto een zand-exporterend systeem is (Van der Meulen et al. 2007). De toepassing van zandsuppleties kan in de toekomst misschien ook moeilijker worden omdat het aantal zandwinlocaties op de Noordzee in de toekomst mogelijk beperkt wordt door ruimtelijk economische ontwikkelingen (I\&W et al. 2019) en bijvoorbeeld verder van de kustlijn komen te liggen (meer kosten voor het winnen van zand).

De uitgevoerde klimaatbuffers die werken met sedimentsuppleties, aanleg van vooroevers en kwelders worden steeds vaker als volwaardig plan-alternatief gezien binnen het HWBP en het Deltaprogramma. Ze kunnen beschouwd worden als een flexibele klimaatadaptatie-strategie die, in bepaalde mate, mee kan groeien met zeespiegelstijging binnen de bandbreedtes van de KNMI scenario's voor 2050 (15 tot 40 centimeter) (Klein Tank et al. 2014). Er is in de evaluatie niet gekeken wat versnelde zeespiegelstijging (Dillingh et al. 2012; Haasnoot et al. 2018; IPCC 2019; Le Bars et al. 2017) betekent voor de effectiviteit van dit type oplossingen. 


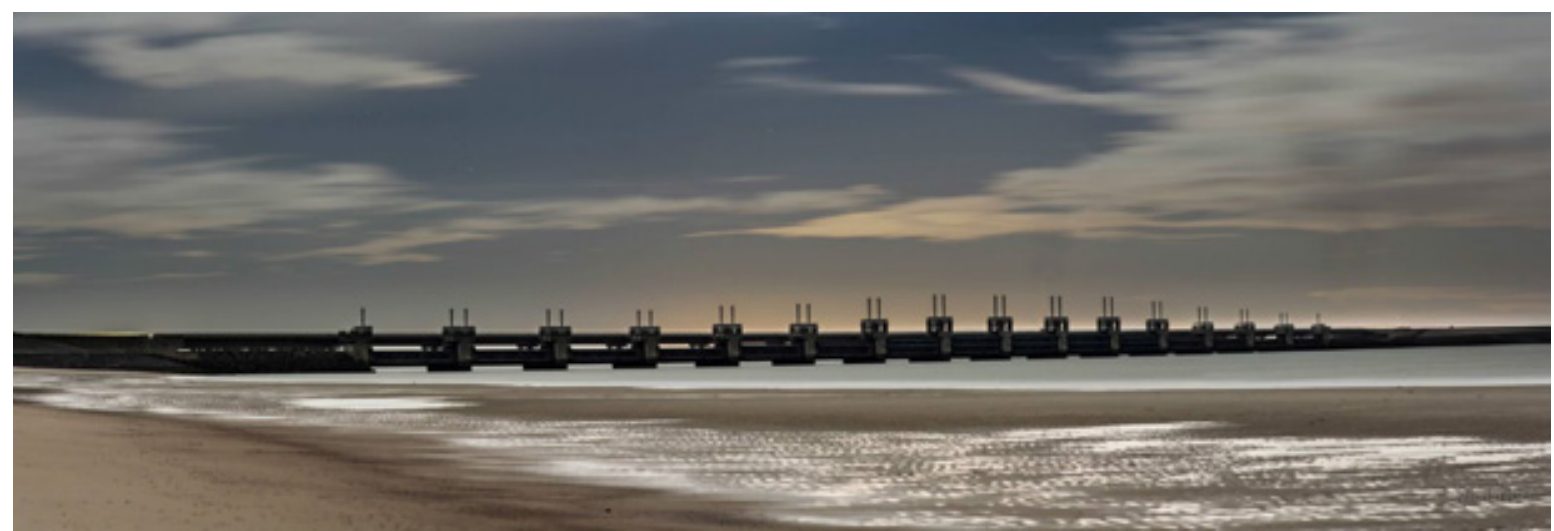

Zandsuppletie bij het Sofiastrand in de Oosterschelde (Foto: Maurice Veraart).

De experimenten met biobouwers (schelpdierbanken, oesterriffen, zeegras) hebben waterbeheerders er nog niet van overtuigd dat deze, onder alle omstandigheden, een alternatief zijn voor dijkversterking in het licht van klimaatverandering (omgevingsscan). Het herstel van dit type habitat is voor de meeste Rijkswateren langs de kust en in de estuaria ook een Natura 2000-opgave. Daarom wordt er toch onderzoek gedaan naar het herstel van dit type ecosystemen. De nevenfunctie (bijdrage aan waterveiligheid) kan zich in de toekomst nog gaan bewijzen. Bij klimaatbuffers met kwelders is dat effect al wel bewezen: die verlagen de golfbelasting op de dijken met ca. 50\%, waardoor zeekering ca een halve meter lager kan worden uitgevoerd (Roode et al. 2019; Vuik et al. 2019). Tot slot dragen kwelders ook bij aan het vastleggen van $\mathrm{CO}_{2}$ (zie sectie 4.3).

\section{Natuur}

De natuurlijke klimaatbuffer Oesterdam laat inmiddels al lokaal herstel van natuurwaarden zien die horen bij intergetijdengebied (sectie 4.8). Op groter systeemniveau zijn de effecten van de gerealiseerde klimaatbuffers van dit type (tabel 5.8) vaak niet aantoonbaar. De zandsuppleties bij de Oesterdam zijn positief voor de wadlopers ter plaatse, maar de zandhonger in de Oosterschelde blijft aanwezig. De verwachting is wel dat dit type klimaatbuffers bij voldoende opschaling natuurlijke processen kan ondersteunen, waarbij ook de heterogeniteit en de biodiversiteit in het landschap zal toenemen (van der Zee et al. 2015). Ook lange-afstand-interacties tussen dit type habitats (intergetijdengebied) kunnen de natuurwaarden versterken (van de Koppel et al. 2015). Hoeveel opschaling er nodig is om tot een robuust/ecologisch veerkrachtig intergetijdengebied te komen op basis van klimaatbufferprincipes in de Zuidwestelijke delta en het Waddengebied is nog een belangrijke kennisvraag. De ervaringen zijn wel aanleiding voor opschaling van dit type maatregelen in de Oosterschelde, Waddenzee en Eems-Dollard. Zo zullen er zandsuppleties worden uitgevoerd bij de Roggenplaat in de winter van 2019 en is de zandsuppletie bij de Galgenplaat en de buitendijkse kwelderherstel in de Dollard opgenomen bij de tweede tranche maatregelen binnen de Programmatische Aanpak Grote Wateren (van Nieuwenhuizen and Schouten 2019).

Bij een aantal van deze klimaatbuffers (tabel 5.8) is het eigenlijk nog te vroeg om al iets te kunnen concluderen over de natuureffecten omdat ze pas zeer recent zijn gerealiseerd. De ecologie heeft tijd nodig om zich te ontwikkelen. Bovendien gaat de ingreep (zandsuppleties) vaak ook gepaard met een tijdelijke verstoring (bijvoorbeeld afname bodemleven na suppletie), maar op langere termijn zijn de effecten positief.

\section{Economie}

Vooroevers, zandsuppleties en kwelderherstel worden steeds vaker als alternatief gekozen voor een harde oplossing, omdat waterschappen en Rijkswaterstaat maatschappelijke en beleidsdoelen met 'zachte oplossingen' makkelijker kunnen combineren met waterveiligheid. Tevens is het in sommige gevallen mogelijk om de investeringskosten of het onderhoud te delen. Het beheer en onderhoud van het Sofiastrand (Oosterschelde) wordt bijvoorbeeld deels betaald door bungalowpark de Roompot en niet alleen door Rijkswaterstaat (Groot et al. 2014). In het KB-project Feugelpôlle is een soortgelijke constructie gerealiseerd: het beheer van deze kwelder door Staatsbosbeheer draagt bij aan de waterveiligheidsopgave van Rijkswaterstaat (van Hattum et al. 2016). Zo zijn er meer voorbeelden. 
De investeringskosten van dijkversterking variëren per locatie ( 5 tot 15 miljoen euro per kilometer) (Vuik et al. 2019) en zijn afhankelijk van de waterveiligheidsopgave, de mogelijkheden voor aanvoer van het bouwmateriaal en randvoorwaarden vanuit de omgeving. De grote variatie in kosten gelden voor zowel traditionele dijkversterking en groene alternatieven. Niettemin is in eerdere evaluaties gesteld dat groene oplossingen een kostenbesparing kunnen opleveren die varieert tussen $€ 0,02$ en $€ 3,5$ miljoen per kilometer dijkversterking ten opzichte van een traditionele dijkversterking met basaltbekleding of asfalt (van Kreveld et al. 2013). Er is een gemiddelde kostenbesparing berekend die lag rond de $€ 1,75$ miljoen per kilometer (Sterk Consulting 2014).

Met begroeide voorlanden en kwelderherstel zijn aanzienlijke kostenreducties mogelijk omdat de golfbelasting op het dijklichaam tot wel 50\% kunnen afnemen omdat daarmee een kleinere dimensionering van de dijk mogelijk is (Vuik et al. 2019). Tot slot kan het onderhoud van een dijk of dam met een voorland het beheer en onderhoud van het dijklichaam uitgesteld worden (kostenbesparing) (Veraart et al. 2016), dit wordt ook bevestigd uit het onderzoek rondom de Oesterdam (sectie 4.8).

\subsection{Groene Airco}

\subsubsection{Inleiding}

Volgens de CNK kunnen klimaatbuffers in de stad voor verkoeling in warme periodes zorgen (Groene Airco), vaak in combinatie met waterberging in en rondom de stad (Groenblauwe Ruimte). Daarnaast dragen ze ook bij aan de kwaliteit van de leefomgeving met stadsnatuur, demping van geluid en vermindering van luchtvervuiling (CNK 2019).

Er zijn nog geen CNK-klimaatbuffers in stedelijke omgeving gestart die primair gericht zijn op verkoeling en het mitigeren van hittestress. Wel heeft de Vogelbescherming verschillende positieve effecten voor natuur in de stad, verkoeling en vermindering van wateroverlast (groene daken, aanpassing bebouwing) op een rij gezet voor de stad Zeist. Verkoeling is wel genoemd als secondair doel bij de KB-projecten Rivierklimaatpark IJsselpoort, IJsselmonde en De Onlanden, maar zonder veel onderbouwing (CNK 2012).

\subsubsection{Bijdragen aan doelen klimaat, natuur en economie}

STOWA, Wageningen Environmental Research en Deltares hebben een Deltafact opgesteld over het omgaan met droogte en hitte in de stad (Jacobs and Stuurman 2019). Deze sectie omschrijft de conclusies uit deze Deltafact die relevant zijn voor natuurlijke klimaatbuffers.

\section{Klimaat}

Volgens de scenario's van het KNMI zal klimaatverandering onder andere leiden tot hogere luchttemperaturen en meer hittegolven waardoor een grotere kans op hittestress ontstaat in stedelijk gebied (Klein Tank et al. 2014). In de stad stijgt de temperatuur sneller door de bebouwing, het zogeheten hitte-eiland effect. De bereidheid om hittestress aan te pakken is bij steeds meer gemeenten aanwezig. Sommige effecten van droogte voor groen in de stad zijn goed zichtbaar, zoals het vergelen van gras, maar dat droogte de hittestress kan versterken en groen ook de watervraag van de stad vergroot is minder zichtbaar. Bij een watertekort bereikt de verdamping ook een maximum of kan zelfs afnemen (boom gaat dood), en dat beïnvloedt weer het verkoelend effect. Klimaatadaptatie zou daarom niet alleen wateroverlast en hittestress, maar ook droogte in de stad moeten adresseren.

Momenteel wordt onderzoek steeds meer gericht op kwantificering van effecten en implementatie van maatregelen om hittestress in stedelijk gebied te verkleinen. Eén van de oplossingsrichtingen betreft het verlagen van de versteningsgraad en daarmee de vergroting van de fractie begroeid oppervlak, bijvoorbeeld door burgers te stimuleren om in hun tuin tegels te verwijderen. De Graaf et al. (2013) concluderen dat verdamping lineair afneemt met de versteningsgraad van steden, wat overeenkomt met een lineaire toename bij toenemende groenfractie. Uit modelstudies is gebleken dat vergroening 
een groter positief effect heeft op hittestress in dichtbebouwde gebieden dan een gewijzigde verhouding tussen laag- en hoogbouw (Koopmans et al. 2018). Recentelijk zijn 'hitte-eiland effecten' voor kleine kernen gerapporteerd oplopend tot 12 graden, in de zomer van 2018 (Terpstra et al. 2019). Terpstra et al. (2019) wijzen op de verkoeling van natuur om de stad, mits hiervan de vochttoestand op orde is.

Verder zijn in het kader van het Deltaprogramma richtlijnen ontworpen voor het maken van hittekaarten voor de gemeentelijke klimaatstresstest en loopt bestuurskundig onderzoek naar de manier waarop gemeenten het beste geholpen kunnen worden bij de implementatie van maatregelen (DPRA 2019). Om beleidsopties te evalueren is kwantificering van koelende effecten van maatregelen cruciaal en blijft monitoring van stedelijke hitte een belangrijke rol spelen.

\section{Natuur}

Gemeenten en kennisinstellingen onderzoeken steeds meer wat de mogelijkheden zijn om het groen in de stad verkoeling te bieden of met groen in de stad water te bufferen. Voorbeelden zijn onder andere Arnhem (Jacobs et al. 2015), Amsterdam Rainproof (Waternet 2019), Middelburg (Stichting CAS and WEnR 2019), Amersfoort (Jacobs and Stuurman 2019), Rotterdam (Groot et al. 2015), Enschede en Drachten (Smit et al. 2014). In deze initiatieven staan klimaatadaptatie en het vergroten van areaal groen in de stad centraal, maar er is veel minder aandacht wat dit extra groen kan betekenen voor biodiversiteit en de ontwikkeling van stadsnatuur.

Natuur rondom de stad kan ook bijdragen aan de klimaatopgaven in de stad, verkoeling bieden voor de burgers. Andersom kan stadsnatuur ook iets betekenen voor de 'echte' natuur aan de rand van de stad. Natuurgebieden aan de rand van de stad bieden meer handelingsperspectief voor de natuurterreinbeheerders (hoofdstuk 6). Deze wisselwerking is nog grotendeels onontgonnen terrein.

\section{Economie}

In de Deltafact (Jacobs and Stuurman 2019) wordt gesteld dat de beschikbare schadefuncties voor kosten-batenanalyses van hitte en droogte deels verouderd zijn, of extrapolaties betreffen vanuit het (verre) buitenland. Schades aan groen door droogte zijn tot op heden niet structureel geïnventariseerd, onderzocht en niet in literatuur terug te vinden. De grootste schade ontstaat waarschijnlijk door uitval van vegetatie. Dan moet de gemeente nieuwe bomen planten. De bijdrage van uitval van bomen en struiken in stedelijk gebied door droogte wordt niet geïnventariseerd.

\subsection{Conclusies}

De volgende vragen waren gesteld over de bijdragen van natuurlijke klimaatbuffers aan klimaatbeleid, natuurdoelen en economie (tabel 1.1):

- Welke bijdrage leveren de afzonderlijke klimaatbuffers aan klimaatadaptatie en -mitigatie, nu en in de toekomst?

- Wat is de natuuropbrengst (invulling van de natuurdoelen/opgaven), naast de opbrengst van de wateropgaven?

- Wat zijn de kosten en baten van klimaatbuffers, i.r.t. andere maatregelen? Hoe (en hoeveel) dragen ze bij aan andere prioritaire omgevingsopgaven?

\section{Algemeen}

Het kwantificeren van de effecten is niet eenvoudig en was tot nu toe ook geen kerntaak van de CNK. Bovendien is gezien de diversiteit en complexiteit van de projecten een effectieve monitoring en evaluatie van klimaatbufferprojecten alleen mogelijk met een heldere omschrijving van het doel en hypotheses die te verkennen zijn bij de uitvoering (lerend implementeren). Dat ontbrak soms bij de eerste klimaatbuffers. Naarmate er meer klimaatbuffers kwamen, groeide de aandacht voor monitoring, vooral wanneer Rijkswaterstaat, waterschappen en stichting EcoShape een leidende rol bij hadden (denk o.a. aan Zachte Zandmotor IJsselmeerkust, Oesterdam, Leuvenumse beek, Punt van Voorne). 


\section{Klimaatadaptatie}

De ervaringen met natuurlijke klimaatbuffers laten zien dat ze bijdragen aan klimaatadaptatie en leiden tot een verbetering van de waterveiligheid en watervoorziening. Natuurlijke vooroevers bij dijken, kwelderherstel, zandsuppleties, piekwaterberging rondom steden en in de uiterwaarden van rivieren bewijzen zich steeds meer als succesvolle klimaatadaptatiestrategieën en daarmee als volwaardig alternatief voor de traditionele aanpak. Eerder is geconcludeerd dat natuurlijke klimaatbuffers vaak last hebben van het innovatiedilemma. Er komen steeds meer voorbeelden waarbij dit innovatiedilemma is overwonnen (bijvoorbeeld de Prins Hendrikzandkdijk), het speelt echter nog steeds wel een rol.

Oppervlaktewaterberging rondom steden in combinatie met natuurontwikkeling is een succesverhaal en naast de beschouwde twintig natuurlijke klimaatbuffers zijn er nog veel meer van dit soort combinaties gerealiseerd in de afgelopen 10 jaar. In het rivierengebied is er extra ruimte voor hoge afvoer, maar er is een extreem hoge afvoer nodig om te kunnen evalueren of de beoogde verlaging van de waterstand uit modelstudies in de praktijk ook gerealiseerd worden.

Het is niet goed te beoordelen of gerealiseerde waterconservering (niet gekwantificeerd) in de individuele projecten ook leidt tot een verbeterd watervasthoudend vermogen en klimaatbestendigheid op stroomgebiedsniveau. De statistieken van het antiverdrogingsbeleid laten nog steeds een toenemende verdroging van natte natuur zien, ondanks klimaatbuffers en overige maatregelen. Er zijn aanwijzingen bij terreinbeheerders dat afgeronde klimaatbuffers de droogte van 2019 en 2018 beter hebben doorstaan in vergelijk tot andere natuur, dit is echter nog niet systematisch onderzocht.

De uitgevoerde buffers die werken met sediment, vooroevers en kwelders (Levende Kust) zijn een flexibele klimaatadaptatie-strategie die mee kan groeien met de scenario's voor zeespiegelstijging van het KNMI tot 2050. Wat versnelde zeespiegelstijging na 2050 betekent is een onderzoeksvraag. De toepassing van biobouwers (schelpdierriffen, zeegras) is nog in de experimentele fase waardoor opschaling nog niet aan de orde is.

Er zijn nog geen natuurlijke klimaatbuffers van het type 'Groene Airco'. Maatschappelijke partners van de CNK zijn hiermee al verder en er is steeds meer wetenschappelijk bewijs dat het verkoelend effect van groen in de stad aantoont. Het verkoelend effect kan wellicht ook gezocht worden in natuurgebieden langs de randen van de stad, een koele uitloopgelegenheid.

\section{Klimaatmitigatie}

Bij de start van de CNK was klimaatmitigatie geen doel, maar er zijn wel KB-projecten in NoordNederland tussen 2008 en 2012 uitgevoerd met potenties voor $\mathrm{CO}_{2}$-eq-vastlegging (De Onlanden, de Hunze) en na 2012 ook in West-Nederland. Landgebonden broeikasgasemissies verklaren 3-4\% van de jaarlijks gerapporteerde emissies. Met natte natuur is een groot deel van de geambieerde emissiereductie voor landgebruik uit het klimaatakkoord realiseerbaar (0,4-0,8 Mton $\left.\mathrm{jr}^{-1}\right)$. Herstel en ontwikkeling van kwelders kan daar via 'blue carbon' nog 0,01 Mton jr-1 aan bijdragen (Vertegaal et al, 2019). Er is meer potentie, met name door uitbreiding van vernatte bufferzones rond natuurgebieden en door functiewijziging op veengrond. Daar is echter maatschappelijk draagvlak voor nodig, gedeeltelijk is dit al afgesproken in het Klimaatakkoord. Wanneer oppervlaktewaterberging rondom steden gerealiseerd wordt op veengrond in combinatie met structurele vernatting en ontwikkeling van moerasnatuur kan klimaatadaptatie gecombineerd worden met klimaatmitigatie.

\section{Natuur}

Het is in deze evaluatie niet altijd gelukt om de natuuropbrengsten systematisch in beeld te brengen omdat projecten op zeer verschillende wijzen projectmonitoring hadden georganiseerd. De klimaatbuffers die zijn meegenomen in deze evaluatie laten vrijwel altijd herstel en ontwikkeling van habitats zien op projectniveau. In de klimaatbufferprojecten die al enige jaren gerealiseerd zijn is het aantal plant- en diersoorten toegenomen of zijn kwetsbare populaties versterkt. Soms spectaculair, zoals de otter en een aantal zeldzame soorten moerasvogels in de Onlanden. In sommige gevallen is er wel een verbetering bereikt, maar was de oorspronkelijke ambitie groter (IJsselmonde). 

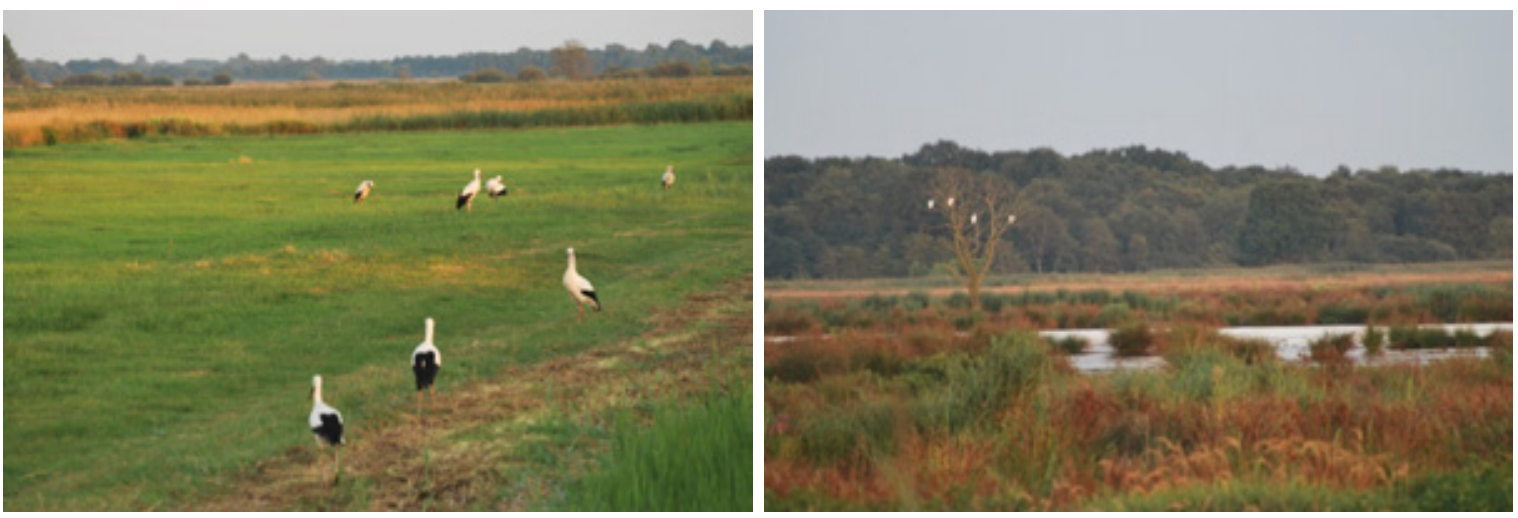

Natuur in de Onlanden (Foto: Paul Vertegaal, Natuurmonumenten).

Uit de beschikbare informatie is afgeleid dat circa 20.000 hectare natuur in Nederland is ingericht met het klimaatbuffer-principe, inclusief de natuurgebieden die meeprofiteren van lokale herstelmaatregelen (4\% van het totale areaal natuur). Hiervan is circa 2000 hectare nieuwe natuur gerealiseerd in de periode 2008-2012.

Of de KB-projecten leiden tot ecologisch systeemherstel op hoger systeemniveau (stroomgebied, waterbekken, etc.) is op dit moment nog niet te evalueren. Er moet eerst voldoende opschaling van lokale maatregelen gerealiseerd zijn. Bovendien, ecologische ontwikkeling heeft ook tijd nodig. De resultaten van verschillende klimaatbuffers zijn wel een aanleiding voor de betrokken waterbeheerders om tot opschaling over te gaan. Zo gaat Rijkswaterstaat verder met de klimaatbufferstrategie in de Oosterschelde.

Bij voldoende opschaling kan de heterogeniteit in het landschap toenemen, neemt de biodiversiteit toe en worden voedselwebben veerkrachtiger. Dat geldt voor alle typen klimaatbuffers: van de Leuvenumse beek tot Oesterdam. En er wordt in Nederland steeds vaker ingezet op het laten toenemen van habitat waarvan steeds minder is, zoals kwelders. Door natuurlijke processen te stimuleren komen soorten ook onverwachts terug, zoals het klein zeegras in de Oosterschelde. Bij de klimaatbuffers in het rivierengebied is nu meer ruimte voor de bijbehorende natuurlijke processen zoals natuurlijkere waterstanden en begrazing. Door wegzijging en het creëren van plasdras-situaties ontstaan er meer kansen voor laag dynamische natuur.

\section{Economie - kosten}

Er zijn steeds meer voorbeelden in het waterbeheer waarbij maatregelen gebaseerd op het klimaatbuffer-principe ook daadwerkelijk een kostenbesparing hebben opgeleverd. De kostenbesparingen van Sterk Consulting specifiek voor kwelders zijn inmiddels beter onderbouwd (Vuik et al. 2019). De belangrijkste kostenbesparing zit in het feit dat de golfbelasting op een dijklichaam tot wel $50 \%$ kan afnemen waarmee een kleinere dimensionering van de dijk mogelijk is (Roode et al. 2019).

In deze evaluatie is voor het eerst de beschikbare informatie van klimaatbuffer-projecten over de investeringskosten van waterberging rondom de stad gecombineerd met natuurontwikkeling. Te concluderen is dat deze variëren van $€ 2$ tot $€ 4$ per $\mathrm{m}^{3}$ oppervlaktewaterberging.

Kostenkengetallen zijn niet onderzocht of gevonden voor klimaatbuffers van het type Groene Airco, Natuurlijke Spons en Koolstof-sink. Wanneer op termijn koolstofvastlegging bij een klimaatbuffer vastgesteld kan worden, dan kunnen de investeringskosten omgeslagen worden naar het aantal ton gerealiseerde CO2-eq-reductie. Bij aanvraag van subsidie of de aankoop van carbon credits moet er bij dit type kengetallen bovendien rekening mee worden gehouden dat een investering in natte natuur bij klimaatbuffers vaak meerdere doelen dient (koolstof, waterberging, etc.).

\section{Economie - baten}

KB-projecten van het type 'Levende Kust', Groenblauwe Ruimte (piekberging rond steden) en Natuurlijke Spons zijn economisch rendabel uit te voeren. Projecten van deze types zijn daardoor 
steeds vaker een volwaardig planalternatief. De baten van klimaatbuffers (voor natuur, klimaatadaptatie, recreatie, schelpdiersector, drinkwaterwinning, e.d.) waren binnen de beschouwde projecten vaker doorslaggevend dan de kosteneffectiviteit.

Wanneer gebufferde natuur water langer vasthoudt, kunnen nabijgelegen landbouwbedrijven hiervan profiteren omdat zij bij droogte beregening kunnen uitstellen; de vermeden arbeidsinspanning van een uitgespaarde beregeningsbeurt is een belangrijk voordeel voor boeren.

Koolstofcertificaten kunnen een financieel aantrekkelijke vorm van extra inkomsten zijn voor de natuurinclusieve boer en natuurterreinbeheerder en een economische prikkel zijn om koolstofneutraal beheer te realiseren. $\mathrm{Bij}$ een $\mathrm{CO}_{2}$-prijs van $€ 5$ ton $^{-1} \mathrm{CO}$-eq op de vrije markt (2018) liggen de extra inkomsten tussen de 30 en $120 \mathrm{ha}^{-1} \mathrm{jr}^{-1}$. Duits onderzoek stelt dat bij een toekomstige prijs van $€ 10$ tot $€ 70$ per ton vermeden $\mathrm{CO}_{2}$-eq herstel van natte natuur met inkomsten uit carbon credits economisch rendabel uit te voeren zijn. $\mathrm{Er}$ is een spreiding gegeven omdat de investeringskosten van het herstel van natte natuur per hectare afhangen van de locatie: als er grond moet worden aangekocht is het veel duurder. 


\section{Hoe kijken anderen naar klimaatbuffers?}

\subsection{Introductie}

Het concept natuurlijke klimaatbuffers zou omschreven kunnen worden als een mobilizing concept (Bremer and Glavovic 2013). Een mobilizing concept is een concept waar veel verschillende visies op bestaan, en die juist daardoor mensen in beweging brengt. Zo'n term kan de lijm zijn die verschillende netwerken met elkaar in verbinding brengt. Het gebruik van de term 'natuurlijke klimaatbuffers' heeft de CNK geholpen om de discussie met partners over klimaatadaptatie te organiseren. Deze rol kan het concept ook vervullen bij het inbedden van het concept in waterbeheer, klimaatbeleid en gebiedsontwikkeling.

De kansen voor nieuwe klimaatbuffers worden vergroot wanneer de percepties en belangen worden meegenomen van partijen waar de boodschap moet aankomen. In de omgevingsscan hebben we onderzocht waar volgens 'belangrijke buitenstaanders' kansen liggen en aan welke voorwaarden de klimaatbuffers moeten voldoen om de kansen te kunnen verzilveren.

Uitkomsten over succes- en faalfactoren en meekoppelkansen die ook in de omgevingsscan aan bod gekomen zijn worden besproken in hoofdstuk 7 en 8 .

\subsection{Beelden van klimaatbuffers}

De omgevingsscan liet zien dat er verschillende beelden zijn over natuurlijke klimaatbuffers. Tabel 6.1 geeft een samenvattend overzicht van de beelden die genoemd zijn in de interviews en de bijeenkomst.

Respondenten die bekend zijn met klimaatbufferprojecten zijn daar positief over. Men geeft aan dat er veel is bereikt ten aanzien van wateropgaves en daarnaast zijn doelen gerealiseerd voor natuur, recreatie en landschap.

Tabel 6.1 Beelden over natuurlijke klimaatbuffers.

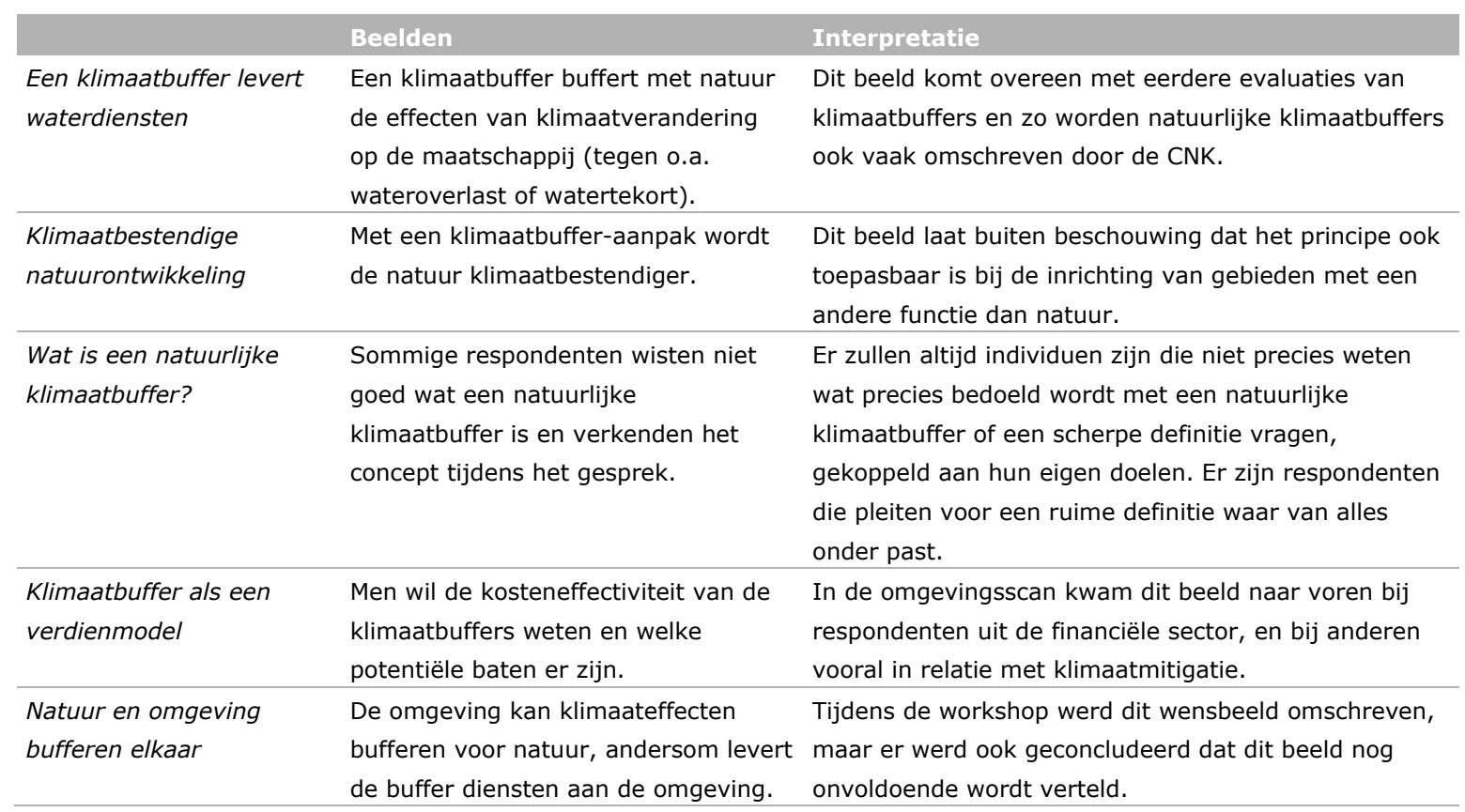


De omgevingsscan laat zien dat er nog vertegenwoordigers van belangrijke stakeholders zijn die minder bekend zijn met natuurlijke klimaatbuffers (zes van de twaalf respondenten). Van sommige respondenten was dit vooraf verwacht (de financiële sector). Soms waren respondenten onbekend met natuurlijke klimaatbuffers omdat de CNK-contact heeft met iemand anders binnen die partij. Ook positiewisselingen spelen een rol.
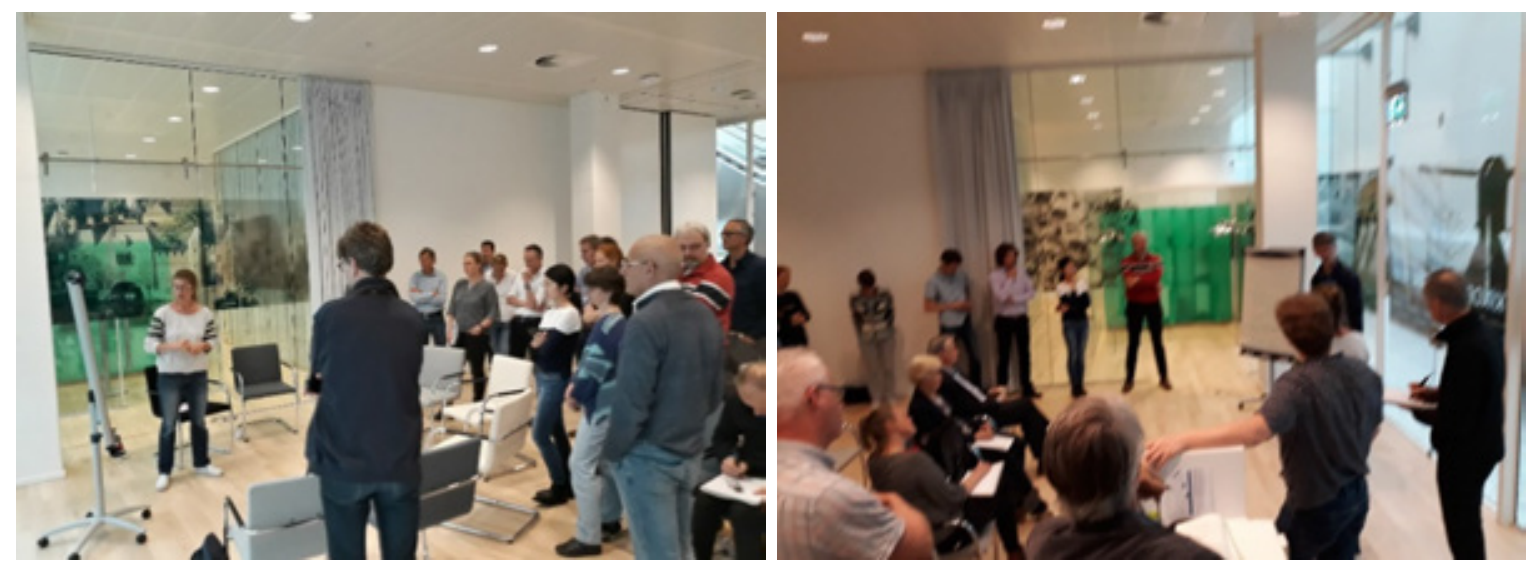

Werksessie met stakeholders bij Staatsbosbeheer (25 april 2019, foto: Michael van Buuren).

\subsection{Betrokkenheid bij klimaatbuffers}

\section{Waterbeheerders}

De omgevingsscan bevestigt de conclusies uit eerdere evaluaties (sectie 3.3) dat de waterschappen en Rijkswaterstaat intensief bij het opzetten van natuurlijke klimaatbuffers betrokken zijn: ze bereiden mee voor, richten het gebied in, en in veel gevallen blijven zij betrokken bij het beheer. Er zijn ook veel gevallen waar het beheer na realisatie van de klimaatbuffer aan een natuurorganisatie wordt overgedragen.

\section{Het Rijk}

De CNK heeft sinds 2008 een intensieve dialoog gevoerd op programmaniveau met de ministeries van Landbouw, Natuur en Voedselkwaliteit (LNV) en Infrastructuur en Waterstaat (I\&W) en het Deltaprogramma. Op projectniveau zijn er verschillende klimaatbuffers gerealiseerd met cofinanciering uit rijksmiddelen. Die middelen kwamen dan bijvoorbeeld uit Rijksbudget voor de Kaderrichtlijn Water (KRW) en het Investeringsbudget Landelijk Gebied (ILG). Uit de omgevingsscan blijkt dat LNV niet direct betrokken is bij de uitvoering van natuurlijke klimaatbuffers omdat het uitvoerende natuurbeheer en bijbehorende budgetten voor zowel aanleg (diverse programma's) als onderhoud (SNL) gedecentraliseerd zijn naar de provincies. LNV is wel betrokken bij natuurlijke klimaatbuffers via LIFE IP Deltanatuur.

\section{Tweede Kamer}

De respondent uit de Tweede Kamer was niet bekend met het concept natuurlijke klimaatbuffers, terwijl deze persoon zeer goed ingevoerd is in het klimaat- en waterdossier. Dit geeft aan dat de naam van het concept zelfs bij een ingevoerd parlementariër toch niet bekend is, ondanks dat de term 'natuurlijke klimaatbuffers' traceerbaar terug te vinden is in moties (meest recentelijk in juli 2019) en klimaatnota's van verschillende politieke partijen. Kamerleden komen en gaan en worden vermoedelijk ook overspoeld met informatie.

\section{Gemeenten}

Op programmaniveau is er weinig aandacht geweest voor gemeenten en hun rol bij de realisatie van natuurlijke klimaatbuffers. Op projectniveau ligt dat anders: bij waterbergingsprojecten rondom de stad (o.a. Groningen, Meppel, Breda, Den Bosch, IJsselmonde) is er intensief samengewerkt met 
gemeenten. Er zijn 355 gemeenten in Nederland, het is arbeidsintensief om daarmee in dialoog te gaan. Een alternatief is om het gesprek met de volgende koepelorganisaties te intensiveren:

- Vereniging van Nederlandse Gemeenten (VNG). De VNG heeft een brede agenda maar door het Deltaplan Ruimtelijke adaptatie krijgt klimaatadaptatie meer prioriteit;

- het Klimaatverbond waarin 163 gemeenten, 9 provincies en 5 waterschappen participeren en waarin klimaatadaptatie en biodiversiteit beiden hoog op de agenda staan (Klimaatverbond 2019).

\section{Provincies}

De CNK heeft op zowel programma- als projectniveau al veel samengewerkt met provincies. In de interviews en workshops is aangegeven dat provincies nu bezig zijn met het opstellen van omgevingsvisies: provincies kunnen het gedachtengoed dat hoort bij natuurlijke klimaatbuffers nu in die omgevingsvisie meenemen wanneer zij hierop geattendeerd worden.

\section{Onderzoeksprogramma's}

De drie geïnterviewde kennisorganisaties (STOWA, stichting EcoShape en Topsector Water) financieren veel onderzoek dat voor natuurlijke klimaatbuffers relevant is. Met STOWA en stichting EcosShape is er al een werkrelatie ontwikkeld. Het is nog niet gelukt om natuurlijke klimaatbuffers in de topsector Water een plaats te geven. Dat komt omdat topsectoren als randvoorwaarde hebben dat private partijen meefinancieren.

\section{Financiële wereld}

Het Nationaal Groenfonds is al betrokken bij projecten die vergelijkbaar zijn met natuurlijke klimaatbuffers. Uit de deskstudie is gebleken dat het Groenfonds heeft opgetreden als voorfinancier bij natuurontwikkelingsprojecten in het Hunze dal. Voor een private belegger, zoals een pensioenfonds, is beleggen in klimaatadaptatie moeilijk omdat er geen of onvoldoende rendement uit wordt verwacht.

Toch zijn er ook indicaties dat verzekeraars en sommige banken in de toekomst meer energie gaan steken in klimaatadaptatie, waterkwaliteit en biodiversiteit. Het Verbond van Verzekeraars doet bijvoorbeeld nader onderzoek naar preventieve maatregelen voor wateroverlast en droogte bij huisen landeigenaren (Brinkman et al. 2018). ${ }^{24}$ Preventie kan ook gerealiseerd worden met natuurlijke klimaatbuffers. Preventieve maatregelen helpen de schadeclaims beheersbaar te houden en het restrisico verzekerbaar met een betaalbare premie voor huis- of landeigenaar. De Nederlandsche Bank (DNB) en de Nederlandse Waterschapsbank hebben recentelijk onderzocht of er redenen zijn om in klimaatadaptatie, waterkwaliteit of biodiversiteit te beleggen (Verdegaal et al. 2018).

\subsection{Doelen van klimaatbuffers}

De bestaande klimaatbuffers hebben diverse doelen, waaronder klimaatadaptatie, klimaatmitigatie, biodiversiteit en bijdragen aan de economie. Deze vier specifieke doelen zijn er tijdens de omgevingsscan uitgelicht. Ze worden door de meeste respondenten onderschreven (respectievelijk $12 x, 9 x, 11 x$ en $8 x$ ) maar respondenten benadrukken ook dat juist de combinatie van deze doelen een belangrijke meerwaarde is van natuurlijke klimaatbuffers.

Daarnaast kunnen extra doelen aan klimaatbuffers worden gekoppeld: sociale cohesie, omgevingskwaliteit en recreatie. Sociale cohesie gaat over de sociale samenhang in een wijk of regio. Ook klimaatbuffers nabij stadsranden kunnen bijdragen aan de sociale cohesie van een buurt. Wanneer natuur dichtbij de stad ligt dan kunnen er bijvoorbeeld culturele activiteiten georganiseerd worden door omwonenden in bijvoorbeeld het bezoekerscentrum. Omwonenden kunnen natuurlijk ook als vrijwilliger meehelpen bij het natuurbeheer. Dit alles kan bijdragen aan sociale cohesie. Dit was in de beschouwde natuurlijke klimaatbuffers nooit een doel. Een goed voorbeeld van een natuurontwikkelingsproject waar dit aspect wel aan bod is gekomen is het LIFE IP-project Getijdenpark Brienenoord (Nuesink and Veraart 2019).

\footnotetext{
${ }^{24}$ In 2014 hebben hierover ook gesprekken plaatsgevonden tussen het Verbond en de CNK om te verkennen wat klimaatbuffers daarbij kunnen betekenen, dat is niet opgevolgd met initiatieven.
} 


\subsection{Kansen voor klimaatbuffers}

De respondenten zien veel kansen voor nieuwe klimaatbuffers in de nabije toekomst. "In de NOVI, de Nationale Omgevingsvisie Nederland, [staan] vier opgaven centraal (...). Dat is klimaatadaptatie, transitie van de landbouw, de verstedelijkingsopgave (...), en de energietransitie. (...). Bij alle vier de opgaven kunnen klimaatbuffers aansluiten." De belangrijkste kansen voor klimaatbuffers, zoals gemeld door de respondenten, zijn weergegeven in tabel 6.2.

Tabel 6.2 Kansen voor natuurlijke klimaatbuffers die zijn genoemd in de interviews.

\begin{tabular}{|c|c|c|}
\hline & Kansen voor nieuwe buffers & Partners \\
\hline Waterberging & $\begin{array}{l}\text { - Waterschapsprojecten versterken tot een klimaatbuffer. } \\
\text { - } 80.000 \text { ha aan extra groenblauwe structuren om het Natuurnetwerk } \\
\text { Nederland te versterken. } \\
\text { - Klimaat robuuste beeklandschappen. }\end{array}$ & $\begin{array}{l}\text { Waterschappen, } \\
\text { provincies }\end{array}$ \\
\hline Droogtebestrijding & $\begin{array}{l}\text { - Samen met de landbouw aan waterconserveringsgebieden werken voor } \\
\text { droge tijden. Meer sponswerking realiseren voor droogte. } \\
\text { - Van geïsoleerde natuurgebiedjes grondwaterbuffers maken en gebiedjes } \\
\text { aan elkaar koppelen samen met lagere overheden. } \\
\text { - Water bovenstrooms in beekdalen bufferen. }\end{array}$ & $\begin{array}{l}\text { Waterschappen, } \\
\text { landbouw, provincies }\end{array}$ \\
\hline Waterveiligheid & $\begin{array}{l}\text { - Projecten waar aan hoogwaterbescherming wordt gewerkt. } \\
\text { - Programmatische Aanpak Grote Wateren in de rijkswateren. } \\
\text { - Programma Integraal Rivier Management, een robuust rivierenlandschap } \\
\text { realiseren door meer natuurlijke processen. } \\
\text { - Methoden om beter om te gaan met sedimentbalans in de Zuidwestelijke } \\
\text { Delta. }\end{array}$ & $\begin{array}{l}\text { Rijkswaterstaat, } \\
\text { waterschappen }\end{array}$ \\
\hline Steden & $\begin{array}{l}\text { - Vergroenen van steden, sponswerking en waterbuffering verbeteren. } \\
\text { - Koppeling aan het Deltaprogramma Ruimtelijke adaptatie en de stresstest } \\
\text { door gemeenten. } \\
\text { - Kwaliteit toevoegen aan de stad, recreatie en sociale cohesie. }\end{array}$ & $\begin{array}{l}\text { Deltaprogramma, } \\
\text { gemeenten }\end{array}$ \\
\hline Mitigatie & $\begin{array}{l}\text { - } \mathrm{CO}_{2} \text { opslaan in bomen, bodem en moerassen. } \\
\text { - } \mathrm{CO}_{2} \text {-uitstoot in veenweidegebieden verminderen. }\end{array}$ & Klimaatakkoord \\
\hline
\end{tabular}

\subsection{Belemmeringen (faalfactoren)}

Naast kansen zijn in de interviews ook belemmeringen aan bod gekomen die de respondenten ervaren om een natuurlijke klimaatbuffer op te starten. De onderstaande opsomming is zoals de respondenten deze belemmeringen ervaren. Bij sommige belemmeringen zijn nuanceringen te maken die na de opsomming besproken worden. De belemmeringen zijn thematisch geclusterd:

\section{Ruimtelijke belemmeringen}

- Er is druk op de ruimte in de Randstad, de stedenring in Noord-Brabant en de overige grote steden; dat zorgt voor hoge kosten van grondverwerving;

- De landbouw krijgt te maken met steeds hogere producteisen van consument en supermarkt, de ondernemer laat zich hierdoor in zijn bedrijfsvoering, die steeds kapitaalintensiever wordt, als eerste leiden, bodem- en waterkwaliteit komen pas daarna. De sector is gevoeliger geworden voor weersextremen want er moet altijd geleverd worden;

- Er komt steeds meer landbouw die los staat van de ondergrond.

Dit laatste punt gaat over voedselproductie in de glastuinbouw en pot- en containerteelt (PCT) van bomen en sierplanten (Box 6.1). De punten van de landbouw zijn door de betreffende respondent naar voren gebracht om aan te geven dat de landbouw zich ook probeert aan te passen aan klimaatverandering en marktwerking. Dit kan de oplossingsruimte voor het realiseren van natuurlijke klimaatbuffers kleiner maken. Uiteindelijk benoemt de betreffende respondent een zoekrichting om met deze belemmering om te gaan: minder droogtegevoelige gewassen telen in natte gebieden met natuur. 
Box 6.1. Pot-, container- en sierteelt (Jeuken et al. 2012)

Sierplanten, die met pot- en containerteelt (PCT) geteeld worden, zijn vaak gevoelig voor irrigatiewater met verhoogde chloridegehaltes. Het is een kapitaalintensieve vorm van landbouw. Voor de bedrijfsvoering is het essentieel om zoetwater beschikbaar te hebben met een laag chloridegehalte. PCTteelt wordt veel toegepast in de landbouw rondom Boskoop, waar het waterschap voor zoetwater afhankelijk is van de inlaat bij Gouda. In tijden van droogte, wanneer de het inlaatwater te zout wordt en de inlaat kan worden gestopt, kan er competitie ontstaan om zoetwater tussen verziltingsgevoelige natuur in Laag-Nederland en de landbouwzoetwatervoorziening (Veraart et al. 2014). Wanneer de landbouwbedrijfsvoering minder zoutgevoelig zou zijn, dan kan langer aan de waterbehoeften van beide typen landgebruik worden voldaan (en dat is klimaatbestendiger). Het landgebruik (natuur en landbouw) in Laag-Nederland beïnvloedt indirect ook de oplossingsruimte voor herstel van estuariene dynamiek in de Zuidwestelijke Delta. Daar wordt naar gekeken in het Deltaprogramma Zoetwater (Delsman et al. 2018; Hydrologic 2018).

\section{Belemmeringen in wet- en regelgeving}

- Complexiteit van meekoppelen: veel doelen leiden tot een noodzaak van samenwerken met veel partijen, wat weer leidt tot lange duur van projecten.

- Het nationaal beleid voor uitbreiding van het Natuurnetwerk Nederland is verzwakt.

- De verplichte compensatie van de Natura 2000-wetgeving is een belemmering, wanneer soorten uit het aanwijzingsbesluit nadelig beïnvloed worden door natuurherstel of ontwikkelingsprojecten.

- Er is een tekort aan mensen bij natuurorganisaties voor lobby en nieuwe initiatieven.

\section{Financiële belemmeringen}

- $\mathrm{Er}$ is een gebrek aan publiek geld voor natuurdoelen.

- Voor beleggingsfondsen en banken is het vaak onduidelijk bij wie het rendement van natuurlijke klimaatbuffers terechtkomt.

- De te realiseren inkomsten uit de aanleg van natuur met carbon credits zijn te laag bij de huidige prijs voor $\mathrm{CO}_{2}$.

- Natuurorganisaties hebben minder grote investeringsbudgetten dan waterschappen, hetgeen in sommige situaties tot discussie kan leiden over de kostenverdeling.

Kosten delen en gezamenlijke uitvoering van klimaatbufferprojecten wordt als kans gezien bij de meeste regionale overheden (hoofdstuk 8). Dat bevestigen ook de voorgaande evaluaties (sectie 3.3) en de gesprekken met de projectleiders van klimaatbuffers (hoofdstuk 4). Niettemin geven de resultaten van de omgevingsscan aan dat sommige regionale overheden toch reserveringen kunnen hebben bij de stelling dat het combineren van doelen leidt tot gedeeld kostendragerschap en kostenbesparing. Bij het starten van klimaatbuffers is het daarom goed de verwachtingen hierover met elkaar te bespreken en niet blind te varen op eerder gerealiseerde successen.

Natuurlijke klimaatbuffers zijn voor beleggingsfondsen (te) kleine projecten in budgettaire zin. Gedeeld kostendragerschap en een dubbeldoelstelling is een succesfactor voor regionale overheden, maar tegelijkertijd een belemmering voor beleggingsfondsen. Het betekent namelijk dat veel meer partijen bijdragen aan het rendement van een investering. Dit type fondsen beleggen hun kapitaal liever bij één (kredietwaardige) partner. Wanneer er meerdere partijen profijt hebben van een klimaatbuffer kan de overheid ook een staatsobligatie uitgeven.

De respondent die het aspect van de $\mathrm{CO}_{2}$-prijs naar voren bracht refereert naar de $\mathrm{CO}_{2}$-prijs die gehanteerd wordt binnen het Europese Emission Trade System (ETS) (NEA 2019). De EU bepaalt een plafond voor de emissierechten dat gelijkstaat aan de totale toelaatbare $\mathrm{CO}_{2}$-uitstoot. Het emissieplafond is afgeleid van de reductiedoelstellingen die de EU wil bereiken en gaat geleidelijk omlaag, waardoor de totale uitstoot in Europa daalt. Een bedrijf dat deelneemt aan emissiehandel krijgt jaarlijks een hoeveelheid gratis emissierechten toegewezen. Daarnaast zijn rechten te verkrijgen via de veilingen of de markt. Wanneer een bedrijf meer emissie heeft dan rechten, dan kan men emissierechten kopen of andersom: verkopen. Vragers en aanbieders handelen in emissierechten en zo komt een $\mathrm{CO}_{2}$-prijs tot stand. In 2019 varieert deze tussen de 25 en 30 euro per ton $\mathrm{CO}_{2}$. Bedrijven onder het ETS zijn meestal grote, energie-intensieve bedrijven uit de elektriciteitssector, raffinageindustrie, chemische industrie en metaalsector. Deze $\mathrm{CO}_{2}$-prijs en -markt zijn niet van toepassing voor 
landbouw en natuur en daarmee eigenlijk niet het juiste referentiekader. Er is ook een vrije markt waar koolstofcertificaten verhandeld kunnen worden. In Nederland is de Greendeal Nationale Koolstofmarkt daar een voorbeeld van. Zij hebben een methode bedacht om koolstofcertificaten uit te geven voor maatregelen in de landbouw en natuur (GDNK 2018) die op de vrije koolstofmarkt verhandeld kunnen worden. De vrije markt voor koolstof bestaat in Europa uit duizenden individuele projecten en er is een grote verscheidenheid aan certificeringsmethoden om $\mathrm{CO}_{2}$-compensatie en prijs vast te stellen. $\mathrm{Er}$ is dus eigenlijk niet één prijs voor de vastlegging van één ton $\mathrm{CO}_{2}$. 


\section{$7 \quad$ Succes- en faalfactoren}

\subsection{Introductie}

Over succes- en faalfactoren bij het realiseren van (mee)koppelkansen voor water, klimaat en natuuropgaven in complexe gebiedsprojecten is al veel bekend in algemene zin (Van Popering-Verkerk and Van Buuren 2016) en er zijn ook eerder succes en faalfactoren geïnventariseerd voor de realisatie van natuurlijke klimaatbuffers (Groot et al. 2014; Smit et al. 2014; Van Hattum et al. 2014).

In dit hoofdstuk zijn de succes- en faalfactoren bijeengebracht en geclusterd die stakeholders en projectleiders genoemd hebben (hoofdstuk 4 en 6 ) en vergeleken met de conclusies uit eerdere evaluaties (hoofdstuk 3.3).

\subsection{Resultaten}

Tabel 7.1 geeft een overzicht van de succes- en faalfactoren die geïnterviewde klimaatbufferprojectleiders ervaren. De groene rijen geven aan dat deze succes- of faalfactor op ongeveer dezelfde wijze wordt ervaren door de respondenten uit de omgevingsscan. De gele rijen geven aan dat een aantal respondenten uit de omgevingsscan een succesfactor omkeert in een faalfactor. In de omgevingsscan zijn succes- en faalfactoren door respondenten vaak in algemene zin genoemd, terwijl projectleiders concrete ervaringen hebben met een klimaatbuffer. Om de analyse te kunnen uitvoeren is de formulering van succes- en faalfactoren daarom algemeen gehouden. De kruisjes in de tabel geven aan in welke gesprekken de betreffende factor is benoemd.

Uit de gesprekken met de projectleiders en stakeholders zijn negen generieke succesfactoren benoemd en zes faalfactoren. Dit is geen uitputtend overzicht. Het was opmerkelijk dat succesfactoren in sommige situaties ook faalfactoren kunnen zijn. Dat was het geval bij:

- Rekening houden met lokale wensen: draagvlak voor natuurlijke oplossingen wordt vergroot door rekening te houden met lokale wensen (succesfactor, voorbeeld: Prins Hendrikzanddijk), maar het kan ook natuurherstel bemoeilijken (voorbeeld: kite surfers bij de Oesterdam).

- Afwegen van natuurbaten: het kan moeilijk zijn om alle positieve en negatieve effecten van natuurlijke oplossingen op verschillende typen natuur in een systeem af te wegen, zeker wanneer de maatregelen genomen worden op de grens van land en water, zee en kust, zoet en zout. Daardoor ervaart de één een natuurlijke oplossing als succes maar twijfelt de ander daarover.

- Het innovatiedilemma: volgens een PBL-evaluatie (2014) moet bij een urgente waterveiligheidsopgave de natuurlijke oplossing (het alternatief) voldoen aan hoge en te bewijzen waterveiligheidseisen. Dit creëert een klassiek innovatiedilemma, want zonder (geëvalueerde) praktijktoepassingen kan dat bewijs niet worden geleverd. Dit werd ook in 2019 genoemd als faalfactor, maar er is ook een kanteling gaande: steeds meer onderzoekresultaten onderschrijven de effectiviteit.

Er was consensus over de volgende succes- en faalfactoren:

- Het is belangrijk om doel en nevendoelen van een natuurlijke oplossing scherp te hebben in een planproces. Wanneer een tweede partij, naast de natuurterreinbeheerder, een belang heeft om een klimaat- en/of natuuropgave te combineren, is dit een succesfactor. Zo'n 'tweede partij' met een natuurbelang naast hun water belang was bijvoorbeeld Rijkswaterstaat (Rivierklimaatpark, Oesterdam), een waterschap/provincie (De Onlanden, Ilperveld, Anserveld-Leisloot) of een drinkwaterbedrijf (Hunze, Schoonwatervallei Castricum).

- Regelgeving (bijvoorbeeld Natura 2000) en financieringsritmes zijn faalfactoren. Het hoge marsritme binnen bijvoorbeeld het Hoogwaterbeschermingsprogramma (ambitie om 50 kilometer dijken te versterken per jaar) kan ertoe leiden dat niet alleen geld maar ook tijd een beperkende factor is voor het realiseren van natuurlijke oplossingen. 
Tabel 7.1 Overzicht van de ervaren succes- en faalfactoren in de interviews met de KBprojectleiders. De factoren uit groene rijen zijn bevestigd in de omgevingsscan, de gele zijn soms tegengesproken.

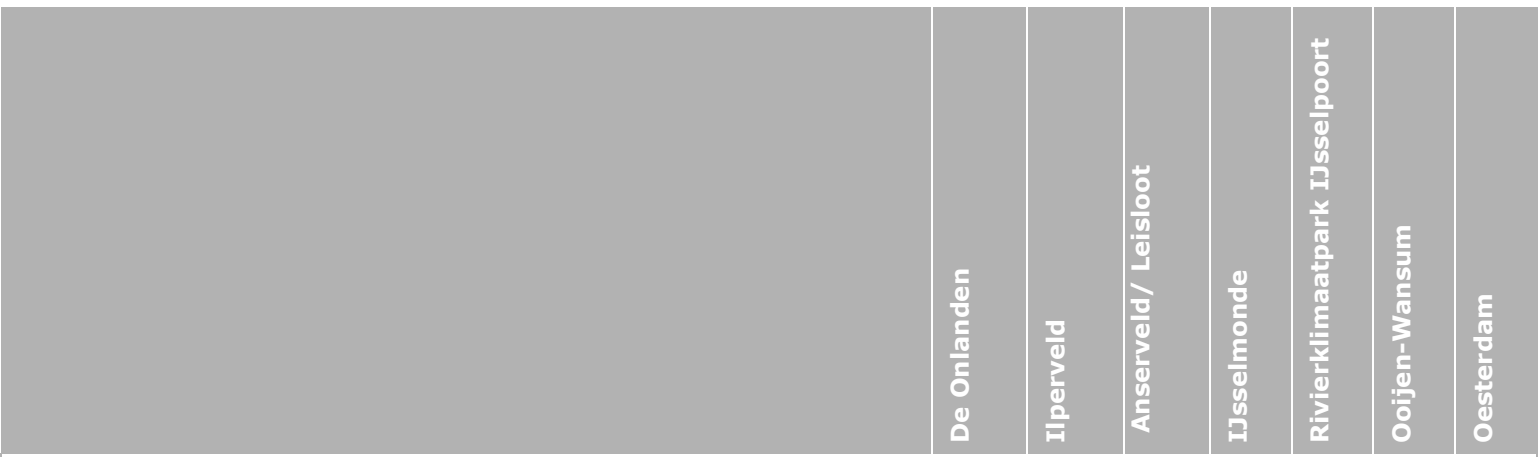

Ervaren succesfactoren bij de projectleiders van geselecteerde klimaatbuffers (interviews)

\begin{tabular}{|c|c|c|c|c|c|c|c|}
\hline (1) & Weersextreem zorgt voor publiek draagvlak & $\mathbf{x}$ & & & & & \\
\hline (2) & Rekening houden met lokale wensen (recreanten, bewoners) & & & & & $\mathbf{x}$ & $\mathbf{x}$ \\
\hline (3) & Bewoners/recreanten mede-eigenaar maken met crowdfunding & & & & & & $\mathbf{x}$ \\
\hline (4) & Beste plan-alternatief in kosten en/of baten & $\mathbf{x}$ & & & & & \\
\hline (5) & $\begin{array}{l}\text { Een tweede partij had baat bij koppelen natuur, water en klimaat en } \\
\text { stelde zich proactief op (vliegwiel) }\end{array}$ & $\mathbf{x}$ & $\mathbf{x}$ & $\mathbf{x}$ & & $\mathbf{x}$ & \\
\hline (6) & Vliegende start (lopend planproces) & $\mathbf{x}$ & & & & $\mathbf{x}$ & \\
\hline (7) & $\begin{array}{l}\text { Eigenaarschap van het succes } \\
\text { "De naam Klimaatbuffer geeft 'vleugels' bij het zoeken financiering" }\end{array}$ & & & $\mathbf{x}$ & & & \\
\hline (8) & Energietransitie compenseren met natuurontwikkeling & & & & & $\mathbf{x}$ & \\
\hline (9) & $\begin{array}{l}\text { Innovatiedilemma: aantoonbaar positief effect als bewijs dat het } \\
\text { werkt }\end{array}$ & & & & $\mathbf{x}$ & & $\mathbf{x}$ \\
\hline
\end{tabular}

Ervaren faalfactoren bij de projectleiders van geselecteerde klimaatbuffers (interviews)

(10) Complexer beheer en onderhoud $\quad$ X

(11) Natura 2000 in tegenspraak met herstel van dynamiek, $\mathbf{x}$ toetsingssystematiek HWBP

(12) Onduidelijke bijdrage natuurontwikkeling aan klimaatbestendigheid medegebruik (scheepvaart)

(13) Risico verlies draagvlak bij bewoners en recreanten doordat de herinrichting leidt tot beperkingen gebruik

(14) Schaal klimaatbuffer te ambitieus of juist te klein voor effect of om erin te beleggen, hoe op te schalen?

(15) Samenwerking met meerdere partijen kost tijd

Genoemd in de omgevingsscan, maar in de interviews met de projectleiders niet benoemd. 


\section{$8 \quad$ Koppelkansen voor natuurontwikkeling met klimaatbuffers}

\subsection{Introductie}

De Nederlandse overheid heeft een aantal grote beleidsopgaven op gebied van water (waterveiligheid en wateroverlast, zoetwatervoorziening en waterkwaliteit), klimaatverandering (mitigatie, adaptatie), ruimtelijke ontwikkeling (woningbouwopgave, energietransitie), landbouw (verduurzaming) en natuur (o.a. beschermen biodiversiteit). Deze opgaven worden vanuit de verschillende beleidsdossiers en programma's en op verschillende bestuurlijke niveaus (Rijk, regio) opgepakt en uitgevoerd. Tabel 8.1 geeft een overzicht van de meekoppelkansen die aan bod zijn gekomen in de workshop en interviews (projectleiders en omgevingsscan).

Tabel 8.1 Overzicht beleidsvelden en -programma's die in beschouwing genomen zijn bij de inventarisatie van meekoppelkansen. Legenda: $\sqrt{ } \sqrt{ }=$ veel meekoppelkansen, $\sqrt{ }=$ enkele meekoppelkansen? = er is discussie over meekoppelkansen. Gebaseerd op interviews en workshop.

\begin{tabular}{|c|c|c|c|c|c|c|c|c|}
\hline \multirow[t]{2}{*}{$\begin{array}{l}\text { Beleidsprogramma of } \\
\text { sector }\end{array}$} & Deelthema's binnen programma & \multicolumn{7}{|c|}{ Indicatie meekoppelkansen } \\
\hline & & 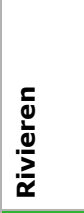 & 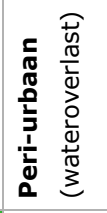 & 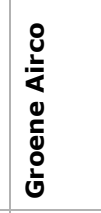 & 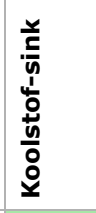 & $\begin{array}{l}n \\
0 \\
0 \\
0 \\
\dot{0} \\
\text { in }\end{array}$ & 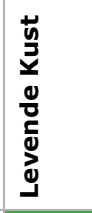 & 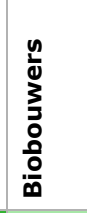 \\
\hline Deltaprogramma & Waterveiligheid & $\sqrt{ } \sqrt{ }$ & & & $\sqrt{ }$ & & $\sqrt{ } \sqrt{ }$ & $?$ \\
\hline \multirow[t]{3}{*}{ (Rijksoverheid 2018) } & Zoetwater & & $\sqrt{ }$ & & & $\sqrt{ } \sqrt{ }$ & & \\
\hline & Ruimtelijke adaptatie & & $\sqrt{ } \sqrt{ }$ & $\sqrt{ } \sqrt{ }$ & & $\sqrt{ }$ & & \\
\hline & Integraal Rivier Management & $\sqrt{ }$ & & & $\sqrt{ }$ & & & \\
\hline $\begin{array}{l}\text { Klimaatakkoord } \\
\text { (Klimaatberaad 2018) }\end{array}$ & $\begin{array}{l}\text { Natte natuur, veenweide, kwelders, } \\
\text { rivieren }\end{array}$ & $?$ & $\sqrt{ } \sqrt{ }$ & & $\sqrt{ } \sqrt{ }$ & & $\sqrt{ }$ & $?$ \\
\hline Kaderrichtlijn Water & Inrichting en emissiebeperking & $\sqrt{ } \sqrt{ }$ & $\sqrt{ }$ & & $\sqrt{ }$ & $\sqrt{ }$ & & \\
\hline Natura 2000 & Vogel- en Habitatrichtlijn & $\sqrt{ } \sqrt{ }$ & $\sqrt{ } \sqrt{ }$ & & $?$ & $\sqrt{ } \sqrt{ }$ & $\sqrt{ } \sqrt{ }$ & $\sqrt{ } \sqrt{ }$ \\
\hline $\begin{array}{l}\text { Nationaal } \\
\text { Natuurnetwerk }\end{array}$ & & $\sqrt{ } \sqrt{ }$ & $\sqrt{ }$ & & $\sqrt{ } \sqrt{ }$ & $\sqrt{ } \sqrt{ }$ & & \\
\hline $\begin{array}{l}\text { Programmatische } \\
\text { Aanpak Grote Wateren } \\
\text { (PAGW) }\end{array}$ & $\begin{array}{l}33 \text { maatregelen in de rijkswateren } \\
\text { gericht op ecologisch herstel } \\
\text { (Rijkswaterstaat 2018b) }\end{array}$ & $\sqrt{ } \sqrt{ }$ & & & $\sqrt{ }$ & & $\sqrt{ } \sqrt{ }$ & \\
\hline Nationaal Waterplan & $\begin{array}{l}\text { Gebiedsagenda's rijkswateren } \\
\text { Hoogwaterbeschermings- } \\
\text { programma (HWBP) }\end{array}$ & \multicolumn{7}{|c|}{$\begin{array}{l}\text { Minder aan bod gekomen in de interviews en workshop. } \\
\text { Gebiedsagenda's bieden meekoppelkansen met } \\
\text { economische sectoren. Het HWBP biedt kansen, maar er } \\
\text { zijn ook faalfactoren. }\end{array}$} \\
\hline $\begin{array}{l}\text { Nationale Adaptatie } \\
\text { Strategie (NAS) }\end{array}$ & & \multicolumn{7}{|c|}{$\begin{array}{l}\text { Er zijn aanknopingspunten benoemd, maar niet } \\
\text { geconcretiseerd. }\end{array}$} \\
\hline $\begin{array}{l}\text { Programmatische } \\
\text { Aanpak Stikstof (PAS) }\end{array}$ & $\begin{array}{l}\text { (Ministerie van Economische Zaken } \\
\text { 2015) }\end{array}$ & \multicolumn{7}{|c|}{$\begin{array}{l}\text { Niet aan bod gekomen in de interviews en workshop. De } \\
\text { maatschappelijke discussie over de stikstof vraagt om } \\
\text { herijking meekoppelkansen tussen landbouw, natuur, } \\
\text { woningbouw en aanleg infrastructuur. }\end{array}$} \\
\hline
\end{tabular}

Daarnaast zijn er meekoppelkansen benoemd voor natuurontwikkeling, klimaatadaptatie met maatschappelijke functies (o.a. landbouw, drinkwater), de financiële sector, scheepvaart, delfstofwinning, recreatie, visserij en bouwsector (tabel 8.2). 
Tabel 8.2 Overzicht van de benoemde meekoppelkansen met verschillende economische sectoren. Legenda: $\sqrt{ } \sqrt{ }=$ veel meekoppelkansen, $\sqrt{ }=$ enkele meekoppelkansen. Gebaseerd op interviews en workshop.

\begin{tabular}{|c|c|c|c|c|c|c|c|c|}
\hline \multirow[t]{3}{*}{ Sector } & \multirow[t]{3}{*}{ Deelthema's binnen programma } & & \multicolumn{6}{|c|}{ Indicatie meekoppelkansen } \\
\hline & & \multirow{2}{*}{\multicolumn{7}{|c|}{$\begin{array}{l}\text { Groene } \\
\text { Ruimte }\end{array}$}} \\
\hline & & & & & & & & \\
\hline Drinkwater & & & $\sqrt{ }$ & & & $\sqrt{ } \sqrt{ }$ & & \\
\hline Landbouw & & $\sqrt{ }$ & $\sqrt{ }$ & & $\sqrt{ }$ & $?$ & & \\
\hline Bouw & & & $\sqrt{ } \sqrt{ }$ & $\sqrt{ }$ & & $\sqrt{ }$ & & \\
\hline Financiële sector & & & $\sqrt{ }$ & & $\sqrt{ }$ & $\sqrt{ }$ & $\sqrt{ }$ & \\
\hline Recreatie & & $\sqrt{ } \sqrt{ }$ & $\sqrt{ } \sqrt{ }$ & & & $\sqrt{ } \sqrt{ }$ & $\sqrt{ } \sqrt{ }$ & \\
\hline Energie & & & & $\sqrt{ }$ & $\sqrt{ }$ & & & \\
\hline Havens & & & & $\sqrt{ }$ & & & $\sqrt{ }$ & \\
\hline Visserij & & & & & & & & $\sqrt{ }$ \\
\hline Scheepvaart & & $?$ & & & & & & \\
\hline Delfstofwinning & & $\sqrt{ }$ & & & & & & \\
\hline \multirow[t]{3}{*}{ Onderzoek } & STOWA & & $\sqrt{ }$ & & & $\sqrt{ } \sqrt{ }$ & $\sqrt{ }$ & \\
\hline & EcoShape, Topsector Water & & & & & & $\sqrt{ }$ & $\sqrt{ }$ \\
\hline & Topsector Agrifood, Tuinbouw & & $\sqrt{ }$ & $\sqrt{ }$ & $\sqrt{ }$ & $\sqrt{ }$ & & \\
\hline
\end{tabular}

Respondenten en workshopdeelnemers uit de omgevingsscan (hoofdstuk 6) zien de meekoppelkansen als een van de belangrijkste pluspunten van natuurlijke klimaatbuffers. Veel respondenten adviseren daarbij om het gesprek met partners open in te gaan om de kansen op samenwerking te vergroten.

Een groeiend besef over de meerwaarde van de combinatie natuurontwikkeling en economische ontwikkeling of klimaatadaptatie blijkt niet alleen uit deze evaluatie, maar ook uit officieel overheidsbeleid. Een betere integratie van ruimtelijke opgaven komt bijvoorbeeld ook steeds meer aan bod in het Deltaprogramma, het Natuurpact, het Klimaatakkoord en het Hoogwaterbeschermingsprogramma (van Rijswijk 2014).

Ook het recente advies van de Commissie Remkes (Remkes et al. 2019) in het kader van de stikstofproblematiek vraagt om uitwerking van meekoppelkansen tussen natuurontwikkeling en behoud met verduurzaming van de landbouw, transport, woningbouw, aanleg/beheer van infrastructuur en recreatie.

In eerdere evaluaties zijn meekoppelkansen benoemd voor klimaatbuffers met de Topsector Water en stichting EcoShape (sectie 3.3). Met stichting EcoShape zijn deze kansen op projectniveau gerealiseerd (Voorbeelden: KB-project Friese IJsselmeerkust en Oesterdam), dat is niet gelukt binnen de Topsector Water. De aansluiting met de topsectoren kan ook gezocht worden via het missiegedreven programma 'Landbouw, Water, Voedsel' waaraan invulling wordt gegeven door het Rijk en de Topsectoren samen. 


\subsection{Koppelkansen met waterbeheer in het rivierengebied}

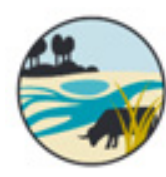

Hoofddoel

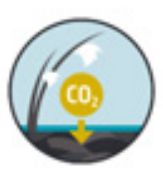

Nevendoelen
In het rivierengebied kan waterbeheer gekoppeld worden met natuurlijke klimaatbuffers van het type 'Groenblauwe Ruimte' (rivieren) en het klimaatakkoord kan gekoppeld worden met klimaatbuffers van het type 'Koolstof-sink'.

\subsubsection{Integraal Rivier Management en Programmatische Aanpak Grote Wateren}

Het programma Ruimte voor de Rivier (looptijd 2007-2018) heeft veel kansen voor natuur kunnen verzilveren. Er liggen nog steeds resterende ecologische opgaven in het rivierengebied (Zuidhof et al. 2017). Deze nog openstaande opgaven worden getackeld binnen de Kaderrichtlijn Water (KRW), de Natura 2000-beheerplannen voor de rivieren, het programma Integraal Rivier Management (Staf Deltacommissaris 2019) en de Programmatische Aanpak Grote Wateren (Rijkswaterstaat 2018b).

Het programma Integraal Rivier Management (IRM) heeft een economisch en ecologisch perspectief terwijl de Programmatische Aanpak Grote Wateren (PAGW) zich alleen richt op de ecologische opgaven in de Rijkswateren. Initiatieven voor natuurlijke klimaatbuffers die natuurontwikkeling combineren met bijvoorbeeld recreatie, delfstofwinning of scheepvaart passen goed binnen het IRM.

Voor het IRM is $€ 375$ miljoen gereserveerd en voor de PAGW $€ 244$ miljoen. De programmering van de maatregelen richt zich op de komende 30 jaar, waarvan een deel al in de komende jaren ( $t / \mathrm{m} \mathrm{2030)}$ (I\&W and LNV 2018). De derde tranche voor KRW-maatregelen biedt tot slot ook financieringsmogelijkheden voor klimaatbuffers in het Rivierengebied.

Tabel 8.3 Koppelkansen voor natur en waterbeheer in het rivierengebied met het PAGWprogramma.

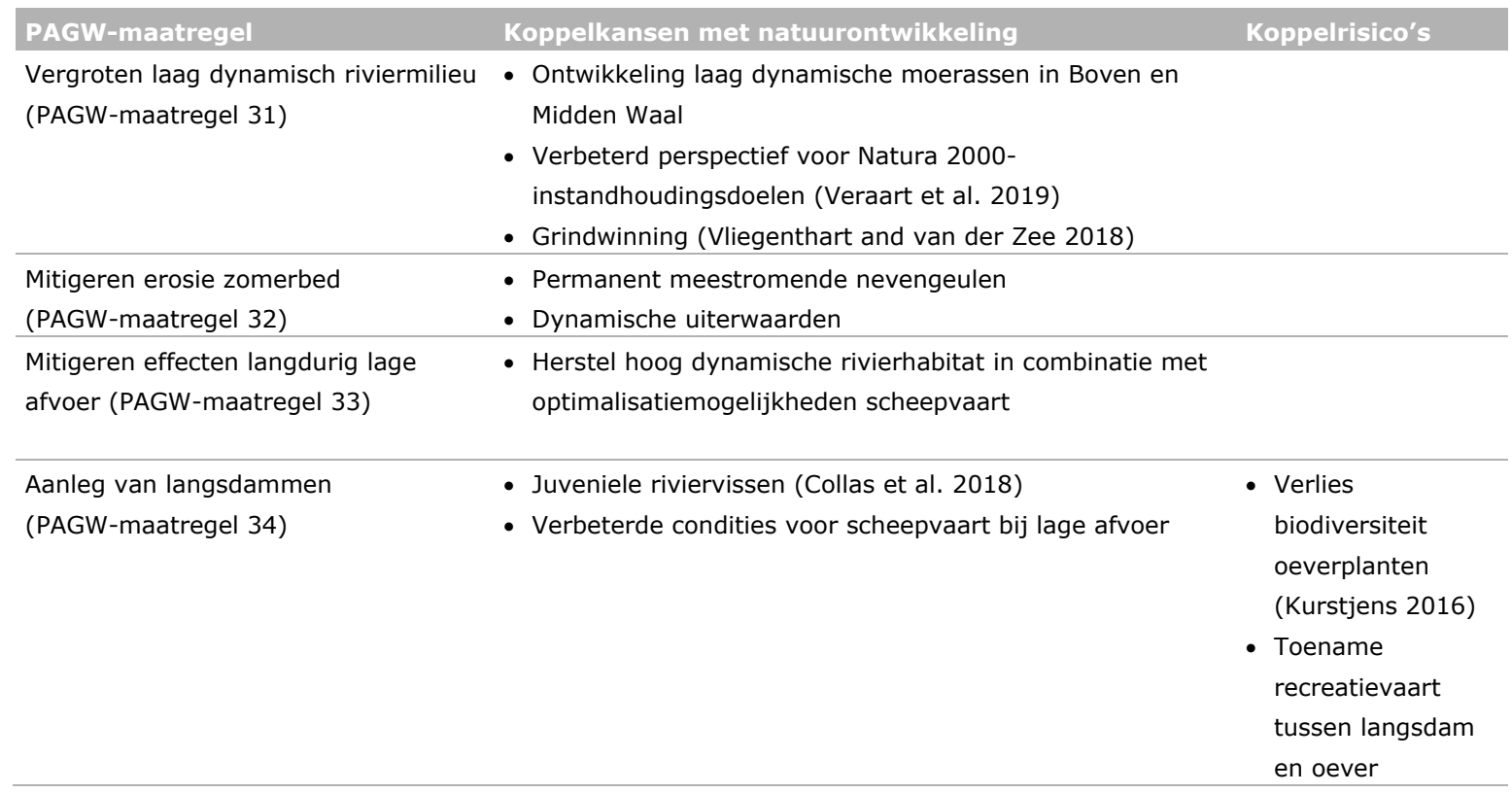

De onderwatermilieus in het winterbed van de Nederlandse rivieren zijn op veel locaties vaak nog ecologisch onvoldoende, blijkt uit KRW-rapportages, ondanks een verbeterde waterkwaliteit (Rijkswaterstaat 2014a; Rijkswaterstaat 2015a; Rijkswaterstaat 2018a). Ook ontbreken verbindingen met zee en met het achterland en krijgen hoog dynamische milieus te weinig water, zeker tijdens lage zomerafvoer (Beekers et al. 2018). Een aantal van de PAGW-maatregelen (tabel 8.3) spelen hierop in. In de PAGW zijn geen maatregelen benoemd die verbindingen tussen zee en achterland herstellen, 
zoals ecologische corridors die lopen van stuwwal naar winterbed of het verbinden van beken met Rijn of Maas.

In het KB-project Rivierklimaatpark IJsselpoort worden er koppelkansen met medegebruikers uitgedacht zoals buitendijkse natuurinclusieve landbouw (interview). De lessen hieruit kunnen ook worden toegepast in vergelijkbare toekomstige projecten binnen het programma Integraal Rivier Management.

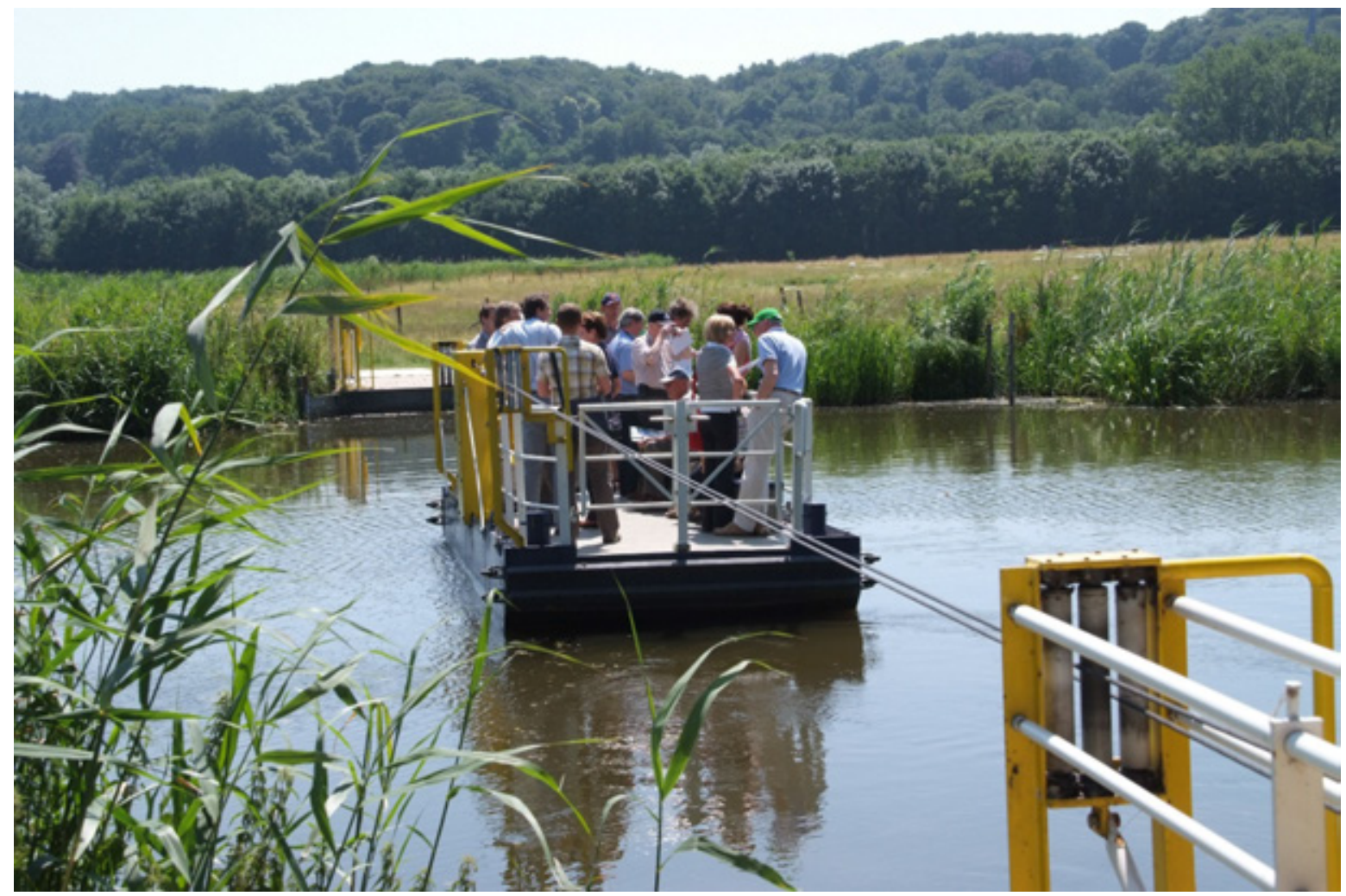

Recreatie in de natuur van het Rivierengebied (Foto: Rob Janmaat, Communicatiebureau de Lynx).

\subsubsection{Deltaprogramma}

Het programma IRM wordt gefinancierd uit het Deltaprogramma en maakt onderdeel uit van de uitvoering van de voorkeursstrategie van Rijn (\& IJssel) en Maas (sectie 8.2.1) en kan gezien worden als de opvolger van Ruimte voor de Rivier.

Daarnaast wordt een deel van de voorkeursstrategie Rivieren (Deltaprogramma) op andere wijze gefinancierd zoals het Hoogwaterbeschermingsprogramma (HWBP). Een Projectoverstijgende Verkenning (POV Voorlanden) binnen het HWBP kijkt naar het inbedden van vooroevers in de normeringssystematiek (Roode et al. 2019). In de POV wordt geconcludeerd dat waterschappen en Rijkswaterstaat tussen 2019 en 2050 minimaal een half miljard euro kunnen besparen wanneer zij besluiten voorlanden stelselmatig mee te rekenen in de normeringsystematiek.

De POV biedt ook handreikingen voor het realiseren van natuurlijke vooroevers aan waterbeheerders en beveelt waterschappen aan om natuurterreinbeheerders in een zo vroeg mogelijk stadium te betrekken. Het hoge marsritme binnen het HWBP (ambitie om 50 kilometer dijken te versterken per jaar) kan de waterschappen nog steeds dwingen om 'sober en doelmatig' te werken: niet alleen geld maar ook tijd is een beperkende factor om de inrichting van vooroevers te realiseren met klimaatbufferprincipes. 


\subsubsection{Klimaatakkoord}

De aanleg van ooibos en broekbos in het riviersysteem (of het toestaan van de ontwikkeling hiervan) is ook een vorm van $\mathrm{CO}_{2}$-vastlegging. Ook omvorming van landbouwgrond naar natte natuur, zoals rivierbegeleidend moeras, zal kunnen leiden tot netto reductie van landgebonden broeikasgassen in het rivierengebied. Deze bijdrage op de nationale broeikasgasbalans is bescheiden omdat het om een gering aantal hectares gaat. In het Klimaatakkoord is de realisatie van 1000 hectare bos in het riviersysteem opgenomen. De aanleg van bos in de uiterwaarden wordt door Rijkswaterstaat niet altijd als wenselijk gezien (verhoging weerstand en daarmee hogere waterstanden bij hoge afvoer)

(Rijkswaterstaat 2014b).

\subsection{Koppelkansen met waterbeheer in Hoog-Nederland}

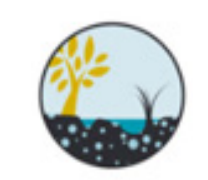

Hoofddoel

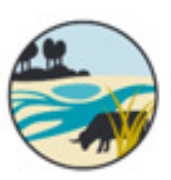

Nevendoelen

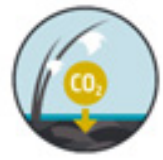

In Hoog-Nederland zijn er in het landelijk gebied koppelkansen tussen waterbeheer en natuurlijke klimaatbuffers van het type 'Natuurlijke Spons'. Het principe biedt een buffer van water in droge tijden. Er zijn steeds meer voorbeelden waarbij dit principe gecombineerd wordt met vastlegging van broeikasgassen (Koolstof-sink) en berging van oppervlaktewater in lagergelegen gebieden (Groenblauwe Ruimte).

De Natuurlijke Spons is een buffer die water kan absorberen (bij een overschot) en weer kan afgeven (bij droogte). Grondwater, (veen)moeras, of oppervlaktewater kunnen als natuurlijke spons fungeren. Deze klimaatbuffer staat na de droge zomers 2018 en 2019 bij veel actoren op het netvlies (INFRAM 2019).

\subsubsection{Deltaprogramma}

Voor de periode $2015-2021$ is $€ 60$ miljoen vanuit het Deltafonds gereserveerd voor een rijksbijdrage aan de beoogde maatregelen binnen het Deltaprogramma Zoetwater. Het gaat onder andere om maatregelen op de 'hoge zandgronden' die structureel bijdragen aan klimaatadaptatie. Dit is uitgewerkt in het Deltaprogramma Hoge Zandgronden ( $\mathrm{DHZ}$ ) en Zoetwatervoorziening Oost-Nederland (ZON), en biedt een meekoppelkans voor het realiseren van natuurlijke klimaatbuffers die gericht zijn op water vasthouden (de Natuurlijke Spons). Voor de periode 2021-2027 is eenzelfde bedrag indicatief aangegeven, voor 'Hoge Zandgronden Noord' en 'Vooroevers IJsselmeergebied' gaat het om kleinere bedragen.

\subsubsection{Klimaatakkoord}

Projecten die waterconservering stimuleren, gelegen op hoogveen, beschermen de koolstofvoorraad en kunnen ook leiden tot groei van hoogveen. Het hoogveengebied in Nederland (landbouw en natuur) vertegenwoordigt een grote koolstofvoorraad ${ }^{25}$. Een extreem droge zomer kan leiden tot verlies van koolstof in hoogveen. Dit is gebeurd in Fochteloërveen tijdens de zomer van 2018

(Natuurmonumenten 2019). Antiverdrogingsmaatregelen in hoogveen kunnen dus twee beleidsdoelen dienen en zelfs drie wanneer er binnen begrensde gebieden van het Nationaal Natuurnetwerk nietbeschermde hoogveengebieden worden aangekocht. Bescherming van deze koolstofvoorraad is gedeeltelijk financierbaar via de koolstofmarkten, voor zover additioneel aan de wettelijke overheidssubsidies voor het natuurbeheer. Groei van nieuw en hersteld hoogveen draagt bij aan de klimaatopgave uit het Klimaatakkoord.

\footnotetext{
${ }^{25} \mathrm{Er}$ is in Nederland $\approx 183000$ ha (afgegraven) hoogveen (alle typen landgebruik). Van dit oppervlakte is $9-10 \%$ gelegen in beschermd natuurgebied, waarvan 3600 ha in goede conditie en slechts enkele hectares betreft groeiend hoogveen.
} 


\subsubsection{Drinkwatersector}

De KB-projecten Hunze (Box 8.1) en Schoonwater Castricum (tabel 5.7) zijn voorbeelden waarin koppelkansen met de drinkwatersector gevaloriseerd zijn. De drinkwatersector heeft in deze evaluatie aangegeven dat de huidige woningbouwopgave in de Randstad betekent dat ook een groei van de watervoorraden voor drinkwatervoorziening noodzakelijk is. Dat kan een functie zijn voor natuur in de Randstad.

Box 8.1. Samenwerking tussen terreinbeheerders met drinkwaterbedrijven in klimaatbuffer de Hunze (van der Zee et al. 2016) en met Nationaal Groenfonds (Nationaal Groenfonds 2018)

\section{Waterbedrijf Groningen}

Waterbedrijf Groningen besteedt het beheer van haar terreinen uit aan Het Groninger Landschap en aan Het Drentse Landschap. Belangrijke onderwerpen voor dit drinkwaterbedrijf waren de afgelopen tien jaar, in relatie tot natuur, het tegengaan van verdroging ten gevolge van waterwinning en het combineren van waterwinning en waterberging. Bij waterwingebied De Groeve is samen met Het Drentse Landschap een natuurontwikkelingsproject ( 90 ha) ontwikkeld. De grond is gekocht door Waterbedrijf Groningen en het beheer wordt in ruil nu kosteloos uitgevoerd door Het Drentse Landschap. Een deel ervan werd in 2016 onder water gezet (moerasnatuur, conform Hunzevisie).

\section{Waterleidingmaatschappij Drenthe}

Waterleidingmaatschappij Drenthe (WMD) heeft dertien waterwingebieden met een totale oppervlakte van circa 850 hectare, het natuurbeheer doet WMD zelf. WMD heeft in het kader van verdrogingsbeleid de waterwinning bij Borger gesloten en de waterwinning in het gebied van de Drentsche Aa verminderd. WMD heeft afspraken gemaakt met terreinbeheerders van de golfclub Zeijerveen/Assen over het gebruik van water, kunstmest en bestrijdingsmiddelen. Ook is een beheerboer actief in een waterwingebied ( $\pm 80 \mathrm{ha}$ ); hier vindt extensieve begrazing plaats, gericht op weidevogels. Er is een peilplan voor stuwen gemaakt met partners (zoals het waterschap), die ervoor moet zorgen dat er in de aanwezige slenken voldoende water blijft. Er zijn kennisuitwisselingsgroepen met agrarische ondernemers in grondwaterbeschermingsgebieden opgestart rondom waterwingebieden. De deelname van boeren is vrijwillig, er worden geen vergoedingen meer betaald ter compensatie voor het gebruik van duurdere bestrijdingsmiddelen of het verbod daarvan in bepaalde gebieden. Circa de helft van de boeren doet mee; de andere helft is moeilijk mee te krijgen.

Het natuurgebied Breevenen in het Hunze dal is in beheer bij Het Drentse Landschap en WMD. In 2011 is geprobeerd om het natuurbeheer te combineren. Dit was geen succes omdat WMD de natuur meer wilde reguleren, terwijl Het Drentse Landschap meer streeft naar spontane processen. Besloten is dat ieder nu zijn deel op zijn eigen manier beheert. De flora in de waterwingebieden van WMD wordt om de drie jaar geïnventariseerd door een ingenieursbureau. Daarnaast werkt WMD samen met diverse vrijwilligers van onder meer IVN, Sovon en Vlinderstichting. Aan het begin van het seizoen is er een bijeenkomst met alle vrijwilligers.

\section{Nationaal Groenfonds}

Het Nationaal Groenfonds (NGF) kan de aankoop van een stuk grond voorfinancieren voor een natuurterreinbeheerder of een provincie. Het fonds kan ook optreden als makelaar tussen provincie en agrarisch ondernemers, wanneer er bijvoorbeeld agrarische gronden moeten worden aangekocht voor het Nationaal Natuurnetwerk. Dit laatste is gebeurd bij klimaatbuffer Hunzedal. Het NGF heeft daarbij ook nagedacht over een passende financieringsvorm voor zowel de provincie Drenthe als de boeren in dit gebied. De provincie Drenthe heeft een bedrag op een rekening bij het Nationaal Groenfonds gereserveerd. Wanneer er ruilgrond kan worden gekocht, leent de provincie het aankoopbedrag van NGF en betaalt ze de bijbehorende rente van het gereserveerde kapitaal.

\subsubsection{Landbouw en voedselproductie}

Binnen het Lumbricus-programma (Waterschap Vechtstromen 2019) denken waterschappen en landbouworganisaties na over het realiseren van mogelijkheden om water vast te houden in combinatie met natuurontwikkeling. Hoewel men dit geen klimaatbuffer-projecten noemt, gebruiken deze initiatieven wel dezelfde principes. Ook provincies, die over grondwaterbeleid gaan, staan mogelijk open om te onderzoeken hoe landbouw en natuur beide kunnen profiteren van waterconservering. Deze indicaties vloeien voort uit de omgevingsscan, maar ook uit recente initiatieven die waterschappen, provincies, land- en tuinbouworganisaties en de voedselverwerkende industrie in de afgelopen tijd ondernomen hebben, zoals: 
- Natuurherstel en verbetering van condities voor landbouwproductie in het Boven-Dinkeldal en zijbeken (Waterschap Vechtstromen 2014) en om het Nieuwe Drostendiep (Waterschap Vechtstromen 2017).

- Het combineren van gezamenlijke waterconservering voor landbouw en natuur in het kader van het Deltaplan Agrarisch Natuurbeheer. Dit zou eventueel ook uit te breiden zijn naar koolstofcertificering voor landbouwsector en natuur, blijkt uit omgevingsscan (paragraaf 8.4).

- Het hergebruiken van afvalwater in voedselverwerkende industrie in combinatie met herstelmaatregelen voor biodiversiteit uit oogpunt van corporate sustainability. Het project 'Groene Cirkels' (Heineken et al. 2019) is daar een voorbeeld van, maar er zijn meer voorbeelden bekend.

- Ook agrarische natuurverenigingen, biologische bedrijven en supermarkten met een biologische signatuur houden zich steeds meer bezig met slimme manieren van water vasthouden in combinatie met bodemverbetering en verhogen biodiversiteit.

\subsection{Koppelkansen met klimaatbeleid}

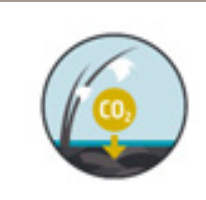

Hoofddoel

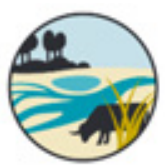

Nevendoelen

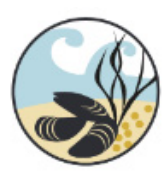

De natuurlijke klimaatbuffers van het type 'koolstofsink' bieden de meeste koppelkansen met klimaatbeleid. Het rendement kan vergroot worden wanneer het vastleggen of reduceren van land gebonden broeikasgassen gecombineerd wordt met water vasthouden en water bergen (klimaat in het kwadraat) (Vertegaal et al. 2019). Het Klimaatakkoord geeft ook een nieuwe impuls aan het afmaken van het Nationaal Natuurnetwerk en het verdrogingsherstelbeleid (Van den Born et al, 2019).

Klimaatmitigatie is, sinds het Klimaatakkoord van Parijs (2015), een hot item in Nederland. Veel burgers, bedrijven, gemeenten en andere overheden zijn begonnen of staan op het punt hier flink hun steentje aan bij te dragen. Expliciete koppeling van natuurlijke klimaatbuffers aan de klimaatmitigatiedoelstelling vergroot het draagvlak voor het inrichten van Nederland op basis van klimaatbuffer-principes. Het kan ook de financiële basis onder klimaatbuffer-projecten versterken wanneer de $\mathrm{CO}_{2}$-vastlegging of -reductie in verhandelbare koolstofcertificaten kunnen worden omgezet.

De $\mathrm{CO}_{2}$-vastlegging moet dan wel gerealiseerd worden met extra maatregelen die niet gefinancierd worden vanuit andere subsidieregelingen voor het realiseren van nationale natuur of milieudoelstellingen. Natuurherstelmaatregelen die bijvoorbeeld al financiering krijgen uit SNL kunnen niet in aanmerking komen voor koolstofcertificaten die uitgegeven worden door de nationale koolstofmarkt. Als aangetoond kan worden dat bepaald beleid niet juridisch verplicht is en de overheid daarvoor de middelen niet heeft/hoeft te verstrekken, dan is het weer wel mogelijk. De koppelkansen die we hieronder bespreken dienen dus altijd getoetst te worden op beleidsadditionaliteit.

\subsubsection{Koppelkansen met Klimaatakkoord}

Vooral landschapstypen die veel broeikasgassen kunnen vastleggen bieden koppelkansen die te vertalen zijn naar verhandelbare $\mathrm{CO}_{2}$-certificaten of kunnen een bijdrage leveren aan de klimaatopgave voor natte natuur uit het Klimaatakkoord. De volgende landschapstypen zijn relevant:

- natte natuur in veenweidegebied;

- kwelders;

- ooibossen

De concrete potenties van deze landschapstypen zijn uitgewerkt in hoofdstuk 5.2. 


\subsubsection{Koppelkansen Deltaprogramma en Klimaatakkoord (kwadraat)}

Op soortgelijke wijze als hierboven kan gekeken worden naar een rol voor koolstofcertificaten voor bestaande klimaatbuffers die relevant zijn voor het Deltaprogramma Zoetwater en Deltaprogramma Ruimtelijke adaptatie, waar klimaatadaptatie en -mitigatie elkaar zouden kunnen versterken zoals de Onlanden (sectie 4.2 en 5.2). Op vergelijkbare wijze kan gekeken worden of noodzakelijke toekomstige piekberging in Laag-Nederland (laagveen, onder 0 meter NAP) gecombineerd kan worden met vastlegging van broeikasgassen en natuurherstel met een gedeeltelijke financiering met koolstofcertificaten van maatregelen binnen het Deltaprogramma Ruimtelijke Adaptatie en Zoetwatervoorziening in Laag-Nederland. $\mathrm{CO}_{2}$-certificaten worden alleen voor natuurherstelprojecten verstrekt die nog niet gefinancierd zijn. Het beheer kan gedekt worden met $\mathrm{CO}_{2}$-certificaten wanneer het project bovenwettelijk veel $\mathrm{CO}_{2}$ vastlegt of als de beheersubsidies/-vergoedingen ontoereikend zijn (GDNK 2018).

\subsection{Koppelkansen met gebiedsontwikkeling in stedelijk gebied}

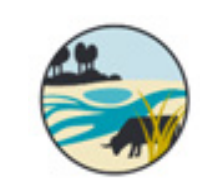

Hoofddoel

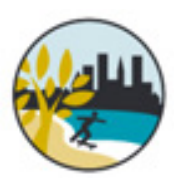

Nevendoelen
In het stedelijk gebied zijn er de belangrijkste koppelkansen tussen Deltaprogramma Ruimtelijke adaptatie en de Nationale Omgevingsvisie met natuurlijke klimaatbuffers van het type 'Groenblauwe Ruimte' (wateroverlast) en het type 'Groene Airco'.

In stedelijk gebied spelen drie transities tegelijkertijd: de woningbouwopgave, de energietransitie en klimaatadaptatie. Ruimte voor voldoende groen en water is belangrijk voor adaptatie. Voldoende schaduw van bomen kan ook tot minder behoefte aan actieve koeling leiden. Hoewel het in deze gebieden niet tot 'donkergroene natuur' zal leiden, kunnen klimaatbuffers in en rond de stad wel bijdragen aan een basiskwaliteit van de biodiversiteit.

CNK-partners hebben veel ervaring opgedaan en successen geboekt met het combineren van natuurontwikkeling met piekwaterberging rondom steden (sectie 5.1). Er is echter nog weinig expertise opgebouwd binnen de CNK over de bijdrage van natuurlijke klimaatbuffer-projecten aan verkoeling bij hittestress in de stad, aan de stadsrand of in het peri-urbane gebied.

De stedelijke omgeving heeft niet voor alle natuurorganisaties evenveel prioriteit, maar voor de Vogelbescherming en de Natuur- en Milieufederaties heeft dit wel de aandacht. Natuur in de stad kan bovendien een nevendoel zijn voor natuurorganisaties om draagvlak onder burgers te realiseren voor natuurbeheer buiten de stad. Er is tijdens de workshop nagedacht waar de mogelijkheden liggen om de prioriteiten voor natuurorganisaties te herijken of te handhaven (a) in de stad, (b) om de stad/aan de stadsrand en (c) hoe condities voor natuur kunnen worden meegenomen bij de nog te realiseren woningbouwopgaves.

\subsubsection{Deltaprogramma Ruimtelijke adaptatie}

Het deelprogramma Ruimtelijke adaptatie (Deltaprogramma) biedt de meest concrete koppelkansen voor het opzetten van verkennende praktijkpilots in/rondom de stad op basis van klimaatbufferprincipes. In het bestuursakkoord Klimaatadaptatie (I\&W et al. 2018) zijn Rijk en regio overeengekomen om gezamenlijk een impulsinvestering te doen van circa $€ 300$ miljoen waarvan zo'n $€ 27$ miljoen voor kennisontwikkeling en -deling met pilots. Voorts is er in dit bestuursakkoord een intentie geformuleerd voor een beleidsreservering uit het Deltafonds, na wetswijziging, met een indicatieve omvang van $€ 150-250$ miljoen. Hierbij moet worden aangesloten bij gemeenten, die in 2019 in regionaal verband stresstesten klimaatadaptatie afronden en beginnen aan oplossingsgerichte 'risicodialogen'. 


\subsubsection{Nationale Omgevingsvisie (NOVI)}

De Nationale Omgevingsvisie (NOVI) richt zich op vier prioriteiten die onderling veel met elkaar te maken hebben en gevolgen hebben voor hoe we onze fysieke leefomgeving inrichten:

- Ruimte maken voor de klimaatverandering en energietransitie (windmolens, aardgasvrije woningen).

- De economie van Nederland verduurzamen (circulair) en ons groeipotentieel behouden.

- Onze steden en regio's sterker en leefbaarder maken (groen, bereikbaar, mooi).

- Het landelijk gebied toekomstbestendig ontwikkelen (waterpeil omhoog, alternatief voor landbouw). Het doel van de NOVI is om hulp te bieden bij noodzakelijke keuzes om deze prioriteiten te realiseren voor 2050. De NOVI kiest voor een duurzame economische ontwikkeling. De ervaringen die zijn opgedaan kunnen de betrokkenen bij de NOVI helpen om een duurzame economische ontwikkeling ook natuurinclusief te realiseren.

\subsection{Koppelkansen langs de kust}

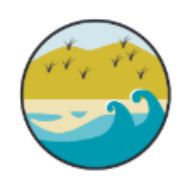

Hoofddoel

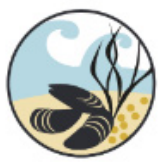

Nevendoelen

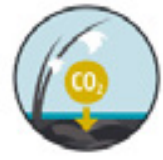

ns de kust is veel ervaring opgedaan met natuurlijke oplossingen voor waterveiligheid die vallen onder het klimaatbuffertype 'Levende Kust'. De aandacht ligt daarbij nog vooral op winst voor veiligheid; de winst voor natuur is nog voor verbetering vatbaar. Het werken met 'biobouwers' om waterveiligheid te realiseren is nog pionierswerk. Er wordt onderzocht welke mogelijkheden er zijn om broeikasgassen vast te leggen met kwelders (blue carbon).

\subsubsection{Deltaprogramma (waterveiligheid)}

Het Deltafonds biedt kansen voor financiering en opschaling van zandige oplossingen, maar er zijn nog wel (potentiële) knelpunten voor opschaling in natuurregelgeving (Bastmeijer 2017; Commissie MER 2019; Veraart et al. 2019), normeringsystematiek en de rol van de (georganiseerde) burgers (hoofdstuk 7). Binnen LIFE IP Deltanatuur wordt voor dit vraagstuk gezocht naar oplossingen met het Natuurwinstplan (Ministerie van LNV and Rijkswaterstaat 2019), waarbij gekeken wordt of Natura 2000-opgaven uitgewisseld kunnen worden tussen gebieden, mede in het licht van klimaatverandering en de invloed daarvan op de realiseerbaarheid van Natura 2000-doelen.

Zoals eerder aanbevolen (Van Hattum et al. 2014) zou er nagedacht moeten worden over een stimuleringsfonds of een budgetallocatie binnen het Deltafonds om kleinschalige maatregelen (pilots met voor- en achteroevers), na de pilotfase, ook daadwerkelijk op te schalen. In de huidige beoordelingssystematieken van het Deltaprogramma en de PAGW scoren kleinschalige zandige maatregelen laag. Door 'gradueel' op te schalen wordt het risico kleiner dat geïnvesteerd wordt in kleinschalige pilots zonder dat de opschaling van de grond komt (desinvestering) (Veraart et al. 2019).

\subsubsection{Koppelkansen met de koolstofcertificaten en PAGW}

De bijdrage van koolstofvastlegging in kwelders in de Eems-Dollard, Zeeuwse Delta en Waddenzee is groot per hectare, maar het areaal is relatief klein. Er kan wel een financieringsmodel zijn om beheer en onderhoud van toekomstige PAGW-maatregelen in de estuaria (Eems, Zuidwestelijke Delta) en Waddenzee mede te financieren op lokale/regionale schaal met $\mathrm{CO}_{2}$-certificaten (GDNK 2018) mits voldaan wordt aan het principe van beleidsadditionaliteit (sectie 8.4) en er meer duidelijkheid is welk deel van het ingevangen koolstof op kwelders allochtoon is (sectie 5.4). Buitendijks kwelderherstel in de Eems-Dollard bij de Punt van Reide is een voorbeeld van een PAGW-maatregel die hiervoor in aanmerking komt (box 8.2). 
Box 8.2. Voorbeeld (hypothese) wat kwelderherstel kan betekenen voor het Klimaatakkoord

Tussen 2006 en 2012 is de oppervlakte kwelder met een Natura 2000-status (H1310, H1320) bij de Punt van Reide afgenomen van $\approx 763$ hectare naar 716 hectare ( $\approx$ afname van 47 hectare) (Baptist and Elschot 2018). Bij een beleidsdoelstelling van behoud van kwelderareaal vertegenwoordigt het herstel van 47 hectare kwelder: (i) een herstel van de $\mathrm{CO}_{2}$-eq vastleggingscapaciteit van 317 tot 437 ton $\mathrm{CO}_{2}$-eq per jaar ${ }^{26}$, (ii) behoud van een vastleggingscapaciteit van 3938-6659 $\mathrm{CO}_{2}$-eq per jaar (op 716 hectare) en (iii) de bescherming van de aanwezige koolstofvoorraad in 716 hectare kwelder $(\approx 608.600$ ton

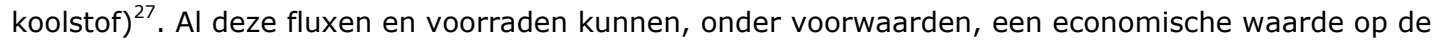
vrijwillige koolstofmarkt vertegenwoordigen.

Ook in de Zuidwestelijke Delta liggen er soortgelijke kansen voor het vastleggen van broeikasgassen door herstel en bescherming van kwelders langs de Westerschelde in samenwerking met Vlaanderen (Grenspark Groot Saeftinge). In de Vlaams-Nederlandse langetermijnvisie voor het Schelde-estuarium (VNSC 2012) zijn Nederland en Vlaanderen overeengekomen dat de verdieping van de Westerschelde en de natuurcompensatie in de Hedwige- en Prosperpolders gecombineerd moeten worden met grensoverschrijdend natuurbeheer. Naar aanleiding hiervan is het Grenspark Groot Saeftinge opgericht met de volgende doelen: het herstel van de vogelbiodiversiteit, optimalisatie van de estuariene natuur en ecohydrologisch herstel van de binnendijkse gebieden (Interreg Vlaanderen-Nederland 2019). Dit initiatief biedt dus ook kansen voor koolstofvastlegging.
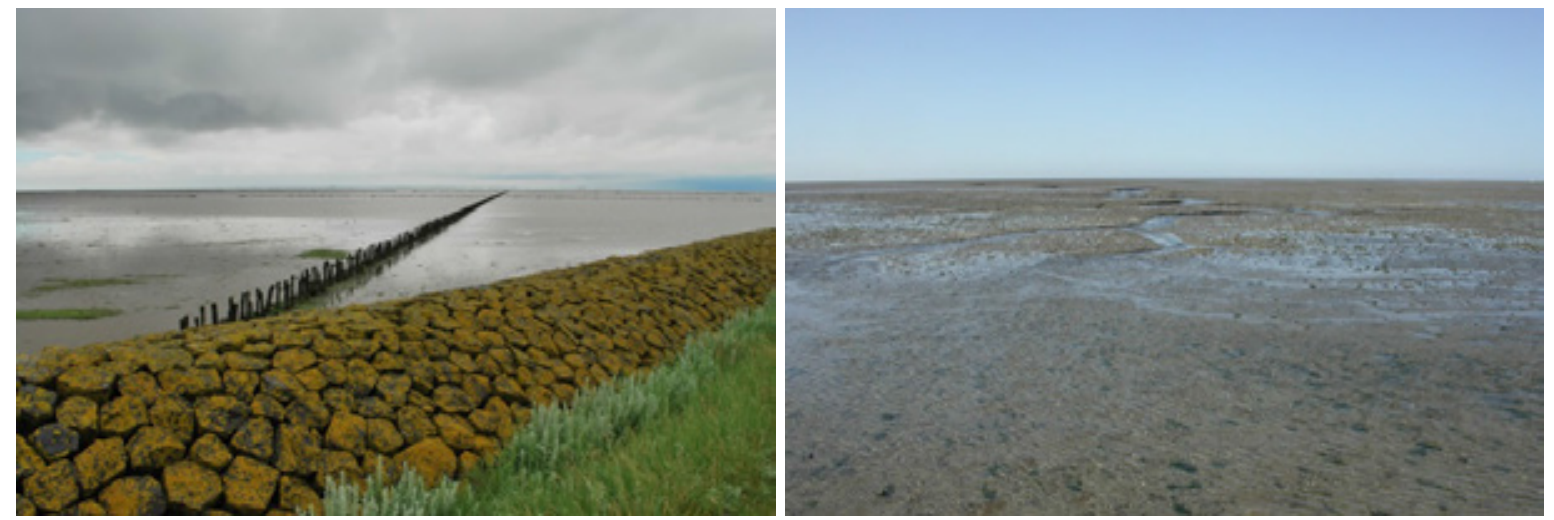

Foto: Kust bij Friesland (Paul Vertegaal, Natuurmonumenten).

\footnotetext{
${ }^{26}$ Gerekend met de gemiddelde $\mathrm{CO}_{2}$-eq opnamesnelheden voor alle kwelders in Nederland van 5,5-9,3 ton CO2-eq ha-1 $\mathrm{jr}^{-1}$ die genoemd worden door Bureau Waardenburg (Teunis and Didderen 2018) en Wageningen Marine Research (Tamis and Foekema 2015).

${ }^{27}$ Gebaseerd op 850 ton koolstof per hectare in kwelders (Teunis and Didderen 2018).
} 


\section{$9 \quad$ Aanbevelingen voor inbedding in beleid}

\section{$9.1 \quad$ Inleiding}

Een succesvolle inbedding betekent dat natuurorganisaties, Rijkswaterstaat, waterschappen, provincies, gemeenten en economische gebruikers (o.a. landbouw, drinkwaterbedrijven) het klimaatbuffer-principe als vanzelfsprekend toepassen wanneer zij nadenken over klimaatadaptatie op hun eigen terrein en/of meedenken over oplossingen of plan-alternatieven met anderen in een groter gebied. De Rijksoverheid (LNV, I\&W, EZK) speelt ook een sleutelrol: zij kan de randvoorwaarden scheppen en dit type maatregelen faciliteren. Bij een succesvolle inbedding is de missie van CNK gerealiseerd en zijn we dichterbij het gewenste toekomstbeeld (figuur 9.1).

"In 2022 zijn natuurlijke klimaatbuffers vanzelfsprekend geworden. De transitie naar natuurlijke oplossingen die bijdragen aan klimaatbestendigheid èn biodiversiteit is daarmee een grote stap verder en onze leerervaringen zijn gedeeld met anderen." (missie CNK)
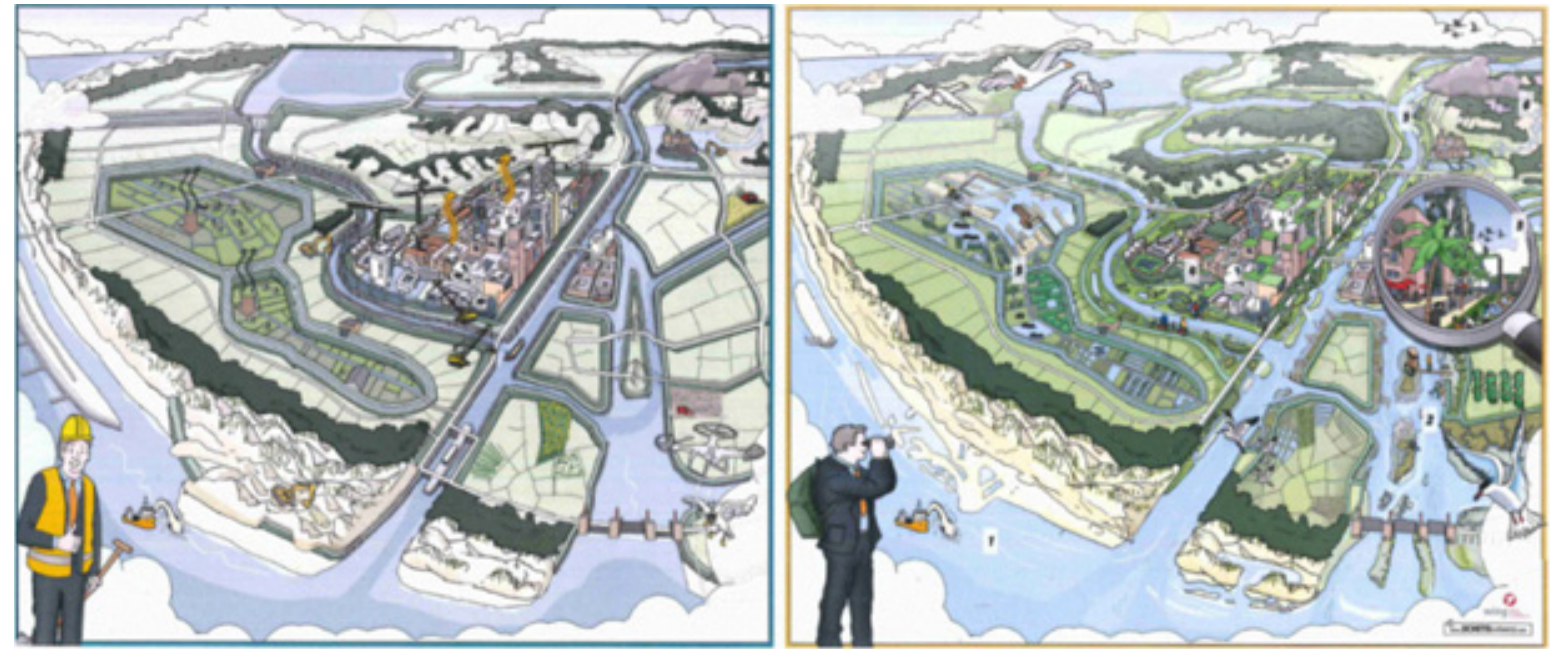

Figuur 9.1 Een toekomstbeeld voor Nederland ingericht met (rechts) en zonder (links) het principe van klimaatbuffers, dat de CNK presenteerde op het Deltacongres 2018.

Deze evaluatie laat zien dat het principe van natuurlijke klimaatbuffers inmiddels de pilotfase wel voorbij is. Het inbedden komt dus langzaam maar zeker op stoom; er is significante vooruitgang geboekt sinds de voorgaande evaluaties uit 2014.

De missie van de CNK is nog niet op alle punten gehaald maar is wel realiseerbaar. Niet elk type natuurlijke oplossing wordt al als vanzelfsprekend beschouwd. Het combineren van waterberging rondom steden met natuurontwikkeling is een voorbeeld van een frontrunner, terwijl het werken met verschillende typen biobouwers nog in de experimentele fase zit.

Er zijn een groot aantal succesvolle lokale initiatieven gerealiseerd. Steeds meer provincies en waterschappen presenteren samen met natuurorganisaties planalternatieven die geïnspireerd zijn op natuurlijke processen en de ambitie hebben om ook natuurwaarden te vergroten. Daarbij maakt het niet uit of die projecten ook het label van 'natuurlijke klimaatbuffer' dragen. 
Een uitdaging is nog hoe tussen 2019 en 2022 van een breed scala succesvolle initiatieven de stap wordt gemaakt naar een samenhangende aanpak op nationaal niveau.

Er zijn geen nieuwe succes- en faalfactoren boven water gekomen bij de introductie van natuurlijke oplossingen. Wel worden de betrokkenen, door leerervaringen, steeds inventiever om het risico op een mislukking te verkleinen en de kans op succes te vergroten.

Wij zien verschillende vliegwielen die het toepassen van de principes achter natuurlijke klimaatbuffers in de ruimtelijke ordening kunnen aanzwengelen. Allereerst zijn dat de toekomstige gebiedsontwikkelingen (zoals woningbouwopgave, energietransitie) en ten tweede de huidige en toekomstige klimaatopgaven.

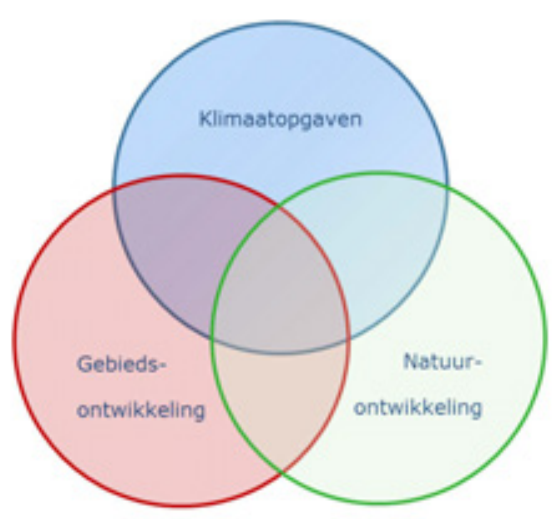

Figuur 9.2 Klimaatopgaven en gebiedsontwikkeling inzetten als vliegwiel voor natuurontwikkeling en toepassing van natuurlijke processen als ontwerpend principe.

Wij doen een aantal aanbevelingen om de missie te realiseren met deze vliegwielen:

- Gebruik toekomstige gebiedsontwikkelingen als vliegwiel

- Gebruik toekomstige klimaatopgaven op nationaal niveau als vliegwiel

- Werk samen met de private sector

- Leer en implementeer samen met onderzoek, beleid en bedrijfsleven

\subsection{Het vliegwiel gebiedsontwikkeling}

Het eerste vliegwiel start met opgaven die er liggen op het gebied van ruimtelijke ontwikkeling, zoals onder andere geformuleerd in de provinciale omgevingsvisies. Deze kunnen verrijkt worden met de ervaringen en ontwerpprincipes uit natuurlijke klimaatbuffers. Als dat lukt, dan komen partijen zoals gemeenten, waterschappen en gebiedsontwikkelaars vanzelf in aanraking met de filosofie achter natuurlijke klimaatbuffers.

De Nationale Omgevingsvisie (NOVI) richt zich op klimaatadaptatie, energietransitie (windmolens, aardgasvrije woningen), verduurzaming van de Nederlandse economie met behoud van groeipotentieel en een toekomstbestendig landelijk gebied. De hiervan afgeleide regionale omgevingsvisies die provincies en gemeenten moeten opstellen bieden koppelkansen voor natuurlijke oplossingen. Concrete aanbevelingen om dit vliegwiel te laten draaien:

- Deel ervaringen in Policy Learning Groups: er zijn veel geslaagde projecten die een 'proof of concept' kunnen zijn voor provincies en/of gemeenten. Om ervaringen te delen kunne Policy Learning Groups opgezet worden, bijvoorbeeld in samenwerking met STOWA en de commissie MER.

- Maak een inhaalslag richting de stad met een lerende pilot: de aanbeveling is om met een lerende pilot te verkennen welke mogelijke rol natuurlijke klimaatbuffers in/rondom de stad kunnen spelen en welke rol natuurorganisaties daarin wel of niet willen nemen. 
- Ontsluit en actualiseer de opgedane ervaring met klimaatbuffers rondom de stad: het gaat dan om klimaatbuffers met waterberging expliciet voor de doelgroepen in het peri-urbane gebied.

Ervaringen kunnen ook worden toegevoegd aan de website van het Deltaprogramma Ruimtelijke adaptatie of worden gedeeld tijdens een kennisdag met partijen zoals STOWA, het Klimaatverbond voor Gemeenten en BIJ12.

- Blijf doelen combineren: de ervaringen laten zien dat doelen combineren, ondanks complexiteit, een kans bieden om meer draagvlak te krijgen voor een klimaatbuffer-project.

\subsection{Nationale klimaatopgaven als vliegwiel}

\section{Het vliegwiel nationale klimaatopgaven met regionale uitwerking}

Het tweede vliegwiel zijn de klimaatopgaven die op nationaal niveau zijn beschreven (omgaan met een toename van het aantal hittegolven en extreme buien, de intensiteit van hevige buien en de perioden van langdurige droogte) maar die op een lager schaalniveau moeten worden opgelost.

Daarbij is het behulpzaam wanneer er meer top-down-verankering is van natuurlijke oplossingen in de planvorming:

- Maak geld vrij uit een stimuleringsfonds: of gebruik een budgetallocatie binnen het Deltafonds. Met deze middelen kan worden gezorgd dat kleinschalige natuurherstelmaatregelen die bijdragen aan waterveiligheid (bijvoorbeeld pilots met voor- en achteroevers), na de pilotfase, ook daadwerkelijk worden opgeschaald.

- Neem natuurlijke oplossingen als standaard mee bij het opstellen van MER-Startnotities.

- Start een ontwerpatelier Klimaat-Ruimte-Biodiversiteit: daarin kan verkend worden hoe landelijke doelstellingen voor klimaatadaptatie, natuuropgaven en ruimtelijke kwaliteit gecombineerd en in samenhang op nationaal niveau uit te werken zijn. Zo is het interessant om te kijken of de opgave binnen het Natuurnetwerk Nederland ( 80.000 hectare nieuwe natuur) te realiseren is samen met het vastleggen van landgebruik gebonden broeikasgassen, doelen voor het realiseren van natuurinclusieve landbouw en het leggen van verbindingen tussen regionale en rijkswateren. Ook het Natuurwinstplan biedt aanknopingspunten.

\subsection{Samenwerken met de private sector}

De private partijen moeten beter betrokken worden om te komen tot een inrichting van Nederland die beter gebruikt maakt van natuurlijke processen. Deze evaluatie laat zien dat de private sector hier ook steeds meer open voor staat.

De drinkwaterbedrijven hebben belang bij goed functionerende ecosystemen en dragen al actief bij aan de realisatie van natuurlijke klimaatbuffers: bescherming van grondwatervoorraden met natuur is een geaccepteerd businessmodel in deze sector en drinkwaterbedrijven voorzien dat de noodzaak vanwege de woningbouwopgave alleen maar zal toenemen.

De financiële sector ziet een businessmodel voor klimaatmitigatie en investeert met name in duurzame energie. Tot voor kort was men terughoudend om te beleggen in klimaatadaptatie en biodiversiteit, maar daar komt langzaam verandering in.

De droogte van 2018 levert nieuwe inzichten op over de financiële risico's van klimaatverandering voor scheepvaart, energieproductie en voedselproductie. Het wordt voor deze sectoren steeds duidelijker dat de risico's groter zijn dan eerder ingeschat. Deze sectoren denken na hoe ze in de toekomst op een andere manier met deze risico's om moeten gaan en nature based solutions zijn daarbij een kansrijke oplossingsrichting. Ruimtelijke investeringen van deze sectoren zullen steeds meer rekening gaan houden met de financiële risico's die horen bij weersextremen.

- Het is een aanbeveling om de samenwerking met de drinkwaterbedrijven, landbouw, voedselverwerkende industrie en financiële sector te zoeken, bijvoorbeeld in het kader van onderzoek in het topsectorenbeleid. 


\subsection{Monitoring en evaluatie met lerend implementeren}

Het kwantificeren van de effecten was binnen deze evaluatie niet eenvoudig en het was tot nu toe ook geen kerntaak van de CNK. Bovendien is (gezien de diversiteit en complexiteit van de projecten) een effectieve monitoring en evaluatie alleen mogelijk met een heldere omschrijving van het doel.

Concrete aanbeveling:

- Lerend implementeren is een manier om innovatiedilemma's te overwinnen en het draagvlak voor het klimaatbuffer-principe te vergroten. Het betekent onder andere dat onderzoekers en stakeholders betrokken worden bij de monitoring van de effecten van maatregelen die water- of natuurbeheerders nemen, en dat hieruit gezamenlijk conclusies worden getrokken. Recente voorbeelden van projecten, buiten het CNK-programma, waar 'lerend implementeren' is toegepast zijn, de Zandmotor, onderzoek naar beekdalherstel binnen het Kennisprogramma Lumbricus en de aanleg van de Marker Wadden. Op basis van de ervaringen hieruit, kan het CNK-programma doorborduren. 


\section{Literatuur}

Agrifirm et al. (2018) Deltaplan Biodiversiteitsherstel - In actie voor een rijker Nederland, Arets EJMM, van der Kolk JWH, Hengeveld GM, Lesschen JP, Kramer H, Kuikman PJ, Schelhaas MJ (2019) Greenhouse gas reporting of the LULUCF sector in the Netherlands - Methodological background, update 2019, vol WOt-technical report 146, Wageningen

Ark Natuurontwikkeling (2014) Klimaatbuffer Kempen Broek - resultaten van het klimaatproject 20102014, Nijmegen

ARK Natuurontwikkeling (2018) Beuningen. https://www.ark.eu/gebieden/gelderse-poort/beuningen. Bezocht op 14/05/2019 2019

Baptist MJ, Elschot K (2018) memo Uitbreiding kwelderareaal in de Dollard, Wageningen Marine Research, Den Helder

Baptist MJ, Geelhoed SCV (2016) Natura 2000 in het habitatrichtlijngebied Eems-Dollard - Een overzicht van status en doelstellingen, IMARES Rapport C054/16. Wageningen Marine Research, IJmuiden

Bastmeijer K (2017) Natura 2000 en zoute en zilte natuur in Nederland - de ruimte voor dynamische en veerkrachtige ecosystemen Natuurbeschermingsrecht 8:256-271

Beekers B et al. (2018) Ruimte voor Levende Rivieren, Coalitie Klimaatbuffers, Amersfoort

Bremer S, Glavovic B (2013) Mobilizing knowledge for coastal governance: Reframing the sciencepolicy interface for integrated coastal management. Coast Manage 41:39-56

Brinkman T et al. (2018) Hoofd boven water - het verzekeren van schade in een veranderend klimaat, Tilburg

Bromet L, de Groot T (2019) Veen red je niet alleen - initiatiefnota over natuur en klimaat in het veenweidegebied, Groenlinks, Den Haag

Brouwer S, Rayner T, Huitema D (2013) Mainstreaming Climate Policy: The Case of Climate Adaptation and the Implementation of EU Water Policy Environment and Planning 31:134 - 153 doi: $10.1068 /$ c11134

CNK (2012) Natuurlijke Klimaatbuffers - kennis en kansen - tussenrapportage 2010-2012, Coalitie Klimaatbuffers

CNK (2014) Verzameling-kennisinventaristaties-2012-2014. http://www.klimaatbuffers.nl/uploads/verzameling-kennisinventaristaties-2012-2014.26b9f5.pdf. Bezocht op 30-11-2019 2019

CNK (2019) Natuurlijke Klimaatbuffers. Coalitie Natuurlijke Klimaatbuffers. https://www.klimaatbuffers.nl/. Bezocht op 04/05/2019 2019

Coenen PWHG et al. (2018) Greenhouse gas emissions in the Netherlands 1990-2016. National Inventory Report 2018, vol RIVM Report 2018-0006, RIVM, Bilthoven

Collas F, Buijse T, Leuven R (2018) Langsdammen in de Waal: kansen voor juveniele vis in druk bevaren rivieren VISIONAIR 48:9-11

Commissie MER (2019) Programmatische Aanpak Ecologie Grote Wateren - Advies beoordelingskader doelbereik, Den Haag

Data ICT Dienst Rijkswaterstaat (2012) Kwelders en schorren, circa 1800 - 2009. PBL. https://www.clo.nl/indicatoren/nl1230-kwelders-en-schorren. Bezocht op 03/04/2019 2019

de Hoop E et al. (2011) Evaluatie Hoogveengebieden in Nederland - Evaluatie van het beheer van de hoogvenen van Natuurmonumenten, Staatsbosbeheer, Landschap Overijssel en het Ministerie van Defensie, Natuurmonumenten/Staatbosbeheer/Landschap Overijssel/Ministerie van Defensie,

De Vriend H, Van Koningsveld M (2012) Building with Nature. Thinking, acting and interacting differently (www.ecoshape.nl). EcoShape, Building with Nature, Dordrecht, the Netherlands.

De Vries F, de Groot WJM, Hoogland T, Denneboom J (2003) De Bodemkaart van Nederland digitaal, Alterra Rapport 811. Alterra, Wageningen

Delsman J et al. (2018) Regioscan Zoetwatermaatregelen - Verkennen van het perspectief van kleinschalige zoetwatermaatregelen voor de regionale zoetwateropgave, Deltares, Delft

Dillingh D, Baart F, De Ronde J (2012) Is er al een versnelde zeespiegelstijging? H2O 14/15:p37-41

DPRA (2019) Hitte. https://ruimtelijkeadaptatie.nl/stresstest/bijsluiter/hitte/. 2019 
During R, Pleijte M, Vreke j (2016) Legitimatie van de nevengeul voor de Waal langs Varik Constructies van risico's uit onzekerheden die redenen geven voor voorzorg - Publieksrapport,

Eelkema M, Wang ZB, Hibma A, Stive MJF (2013) Morphological effects of the Eastern Scheldt storm surge barrier on the ebb-tidal delta Coastal Engineering Journal 55:1350010 doi:http://dx.doi.org/10.1142/S0578563413500101

Feddes Y, van Boheemen Y, Jansen S, Balk R (2018) Ontwikkelingsperspectief Grote Wateren, Feddes/Olthof

Fiselier J, Jaarsma N, Van der Wijngaart T, De Vries M, Van de Wal M, J. S, Baptist MJ (2011) Perspectief natuurlijke keringen, Building with Nature/Ecoshape

Fritz $C$ et al. (2017) Meten is weten bij bodemdaling-mitigatie Bodem 2

GDNK (2018) Methode voor vaststelling van emissiereductie CO2-eq - CO2-emissiereductie via verhoging grondwaterpeil in veengebieden ('Valuta voor Veen'), Greendeal Nationale Koolstof Markt

Groot AE, Van Leeuwen CJ, Tangelder M, Timmerman JG, Werners SE, van Loon-Steensma JM (2014) Governance van innovatieve dijkconcepten in de Zuidwestelijke Delta. Handreiking voor projecten die veiligheid, economie en ecologie van een dijkzone combineren, Alterra-rapport 2506. Alterra, Wageningen

Groot AME, Bosch PR, Buijs S, Jacobs CMJ, Moors EJ (2015) Integration in urban climate adaptation: Lessons from Rotterdam on integration between scientific disciplines and integration between scientific and stakeholder knowledge Building and Environment 83:177-188 doi:http://dx.doi.org/10.1016/j.buildenv.2014.07.023

Haasnoot $M$ et al. (2018) Mogelijke gevolgen van versnelde zeespiegelstijging voor het Deltaprogramma - Een verkenning, Deltares rapport 11202230-005-0002. Deltares, Delft

Hamrick K, Gallant M (2018) Voluntary Carbon Market Insights: 2018 Outlook and First-Quarter Trends. Ecosystem Marketplace, Forest Trend. Washington, USA

Hazelhorst HJ (2014) MAATREGELENSTUDIE DROGE VOETEN 2050, Waterschap Noorderzijlvest Heineken, Provincie Zuid-Holland, Wageningen Environmental Research, Hoogheemraadschap van Rijnland, Naturalis Biodiversity Center (2019) Groene Cirkels. Heineken. https://www.groenecirkels.nl/nl/groenecirkels.htm. Bezocht op 04/11/2019 2019

Hekkenberg M (2019) Effecten ontwerp klimaatakkoord, PBL-publicatienummer: 3619. Planbureau voor de Leefomgeving, Den Haag

HHNK (2019) Prins Hendrik Zanddijk - Sterke dijken, veilige toekomst! https://www.hhnk.nl/prinshendrikzanddijk. Bezocht op 07/05/2019 2019

Hoogland F, Roelandse A, de La Loma Gonzalez B, de Vos A (2019) Bacteriën bepalen de snelheid van veenafbraak H2O-magazine (online) Juli 2019:9

Hunze en Aa (2018) Brede Groene Dijk. https://www.hunzeenaas.nl/werk-inuitvoering/bgd/Paginas/default.aspx. Bezocht op 29-10-2019 2019

Hydrologic (2018) Vervolgonderzoek kosten en effecten permanente oostelijke zoetwateraanvoer voor West-Nederland Amersfoort

I\&W, LNV (2018) Kamerbrief over besteding enveloppe Natuur en Waterkwaliteit (7 maart 2018), Den Haag

I\&W, LNV, EZK (2019) Kennisagenda Noordzee 2030 Bijlage van de Strategische Agenda en het Uitvoeringsprogramma Noordzee 2030 Den Haag

I\&W, VNG, UvW, IPO (2018) Bestuursakkoord Klimaatadaptatie, Ministerie van Infrastructuur en Water, Den Haag

INFRAM (2017) Joint Fact Finding Alternatieve Zoetwateraanvoer West-Nederland,

INFRAM (2019) Rapport eerste fase Beleidstafel Droogte, Ministerie van Infrastructuur en Waterstaat, Den Haag

Interreg Vlaanderen-Nederland (2019) Grenspark Groot Saeftinghe. https://www.grensregio.eu/projecten/grenspark-groot-saeftinghe. Bezocht op 14/06/2019 2019

IPCC (2019) Special Report on the Ocean and Cryosphere in a Changing Climate

It Fryske Gea (2019) 17 MILJOEN VOOR STERKE ÉN MOOIE FRIESE IJSSELMEERKUST. https://www.itfryskegea.nl/17-miljoen-voor-sterke-en-mooie-friese-ijsselmeerkust/. Bezocht op 24-10-2019 2019

Jacobs C, Elbers J, Brolsma R, Hartogensis O, Moors E, Rodríguez-Carretero Márquez MT, van Hove B (2015) Assessment of evaporative water loss from Dutch cities Building and Environment 83:2738 doi:https://doi.org/10.1016/j.buildenv.2014.07.005 
Jacobs CMJ, Moors E, Dolman H (2008) Broeikasgassen in en uit ecosystemen geografie 9:20-23

Jacobs CMJ, Stuurman RJ (2019) Droogte en hitte in de stad, STOWA, Amersfoort

Jansen AJM, Ketelaar R, Limpens J, Schouten MGC, van Tweel-Groot L (2013) Kartering van de habitattypen: actief en herstellend hoogveen in Nederland. vol rapport 2013/OBN182-NZ, Bosschap, Driebergen

Jeuken A et al. (2012) Opties voor een klimaatbestendige zoetwatervoorziening in Laag-Nederland, KvK rapportnummer 55/2012 (Midterm Assessment). Kennis voor Klimaat, Utrecht

Jones CG, Lawton JH, Shachak M (1994) Organisms as Ecosystem Engineers oikos 69:373-386

Jones CG, Lawton JH, Shachak M (1997) Positive and negative effects of organisms as physical ecosystem engineers Ecology and Society 78:1946-1957

Joosten $\mathrm{H}$ et al. (2015) MoorFutures $\AA$ - Integration of additional ecosystem services (including biodiversity) into carbon credits - standard, methodology and transferability to other regions, BfNSkripten 407. Bonn, Germany

Kempen B, Brus DJ, Heuvelink GBM (2009) Updating the 1:50,000 Dutch soil map using legacy soil data: A multinomial logistic regression approach Geoderma 151:311-326

Klein Tank A, Beersma JJ, Bessembinder JJE, Van den Hurk B, Lenderink G (2014) KNMI'14 Klimaatscenario's voor Nederland, leidraad voor proffessionals, KNMI, de Bilt

Klimaatberaad (2018) Ontwerp van het Klimaatakkoord, Sociaal-Economische Raad, Den Haag

Klimaatverbond (2019) Klimaatverbond Nederland. https://www.klimaatverbond.nl/. Bezocht op $14 / 06 / 20192019$

Knotters M, Walvoort D, Brouwer F, Stuyt L, Okx J (2018) Landsdekkende, actuele informatie over grondwatertrappen digitaal beschikbaar H20-Magazine On-line: 11

Koopmans S, Ronda R, Steeneveld G-J, Holtslag AAM, Klein Tank AMG (2018) Quantifying the Effect of Different Urban Planning Strategies on Heat Stress for Current and Future Climates in the Agglomeration of The Hague (The Netherlands) Atmosphere 9:353

Kroon P, Schrier-Uijl A, Stolk P, Van Evert P, Kuikman P, Hensen A, Veenendaal EM (2012) Beïnvloeden van landgebonden broeikasgasemissies? Landschap:99-109

Kurstjens G (2016) Effect van langsdammen op stroomdalflora langs de Waal - 0-situatie na aanleg, ARK Natuurontwikkeling

Kwakernaak C, Verhoeven J (2013) ORAS Veenweidegebieden. stichting Kennis voor Klimaat. http://www.veenweidegebieden-oras.nl/. Bezocht op 16-01-2014 2014

Landinrichtingscommissie Peize (2006) Herinrichting Peize - Voorontwerp Landinrichtingsplan - Milieu Effect Rapportage, Groningen

Landschap Noord-Holland (2015) Start onderzoeksproject 'Omhoog met het Veen'. https://www.landschapnoordholland.nl/nieuws/start-onderzoeksproject-omhoog-met-het-veen. Bezocht op 08-06-2015 2015

Le Bars D, Drijfhout S, de Vries H (2017) A high-end sea level rise probabilistic projection including rapid Antarctic ice sheet mass loss Environ Res Lett 12:9 doi:https://doi.org/10.1088/17489326/aa6512

Lievense Ingenieurs (2018a) De Onlanden - Naar een klimaat-robuust watersysteem. http://comlievense.dev.sier.online/wp-content/uploads/F3-Onlanden-I.pdf. Bezocht op 04-06-2019 2019

Lievense Ingenieurs (2018b) Het Reestdal - een innovatieve manier van wateropslag. https://lievense.com/wp-content/uploads/E2-Reestdal-I.pdf. Bezocht op 04-06-2019 2019

Lievense Ingenieurs (2018c) Schoonwatervallei Castricum - Duinwater als bron voor gebiedsontwikkeling. https://lievense.com/wp-content/uploads/F1-Schoonwatervallei-Castricum180710.pdf. Bezocht op 05/06/2019 2019

LIFE IP Consortium (2016) Programme Proposal LIFE IP Delta Nature (stage II) Ministry of Economic Affairs, Den Haag

Limpens J, van Duinen GA, Jansen JMA, Schouten MGC, Tomassen HBM (2016) Sleutels tot herstel van hoogveen Landschap 3:83-91

Lototskaya AA, Verdonschot PFM, Dekkers TBM (2011) Steekmuggen in de waterbergingsgebieden Peize en Roden: monitoring 2010, Alterra, Wageningen-UR, Wageningen

Ministerie van Economische Zaken (2014) Natuurambitie Grote Wateren 2050 en verder. Den Haag

Ministerie van Economische Zaken (2015) Het Programma Aanpak Stikstof (PAS). http://pas.natura2000.nl/. Bezocht op 09-06-2015 2015 
Ministerie van LNV, Rijkswaterstaat (2019) Natuurwinstplan voor de grote wateren. Ministerie van LNV. https://life-ip-deltanatuur.nl/news/view/58797689/natuurwinstplan-voor-de-grote-wateren. Bezocht op 04/11/2019 2019

Ministerie van Verkeer en Waterstaat (2007) Hydraulische Randvoorwaarden primaire waterkeringen voor de derde toetsronde 2006-2011 (HR 2006)

Mueller P, Ladiges NJ, A., Schmiedl G, Kutzbach L, Jensen K, Nolte S (2019) Assessing the long-term carbon-sequestration potential of the semi-natural salt marshes in the European Wadden Sea Ecosphere: 15 doi:https://doi.org/10.1002/ecs2.2556

Mulder $\mathrm{M}$ et al. (2018) Waterwijzer landbouw: Instrumentarium voor kwantificeren van effecten van waterbeheer en klimaat op landbouwproductie STOWA Rapport 48. Amersfoort

Nationaal Groenfonds (2018) Herinrichting Hunzedal - Financiering biedt kansen voor natuur én boeren Nationaal Groen Fonds. https://www.nationaalgroenfonds.nl/projecten/herinrichtinghunzedal. Bezocht op 29/03/2019 2019

Natuurmonumenten (2019) Fochteloërveen blijkt lek. https://www.natuurmonumenten.nl/natuurgebieden/fochteloerveen/nieuws/fochteloerveen-blijktlek. Bezocht op 04/11/2019 2019

NEA (2019) Nederlandse Emissie Authoriteit - Wat is emissiehandel? https://www.emissieautoriteit.nl/onderwerpen/wat-is-emissiehandel. Bezocht op 3/11/2019 2019

Nuesink N, Veraart JA (2019) Gebruik kennis over sociale waarden bij besluitvorming en ontwerp van natuurherstel- en ontwikkelingsprojecten - lessen geleerd uit LIFE IP Delta-Natuur, vol Adviesmemo voor LNV, Wageningen Environmental Research, Wageningen

Ofori K (2018) Resilience in river ecosystems in the Netherlands - Looking at feedbacks in socioecological systems. Wageningen University

Oude Essink G et al. (2019) GO-FRESH: Valorisatie kansrijke oplossingen voor een robuuste zoetwatervoorziening - Rendabel en duurzaam watergebruik in een zilte omgeving, Deltares, Utrecht

Paas W (2016) LIFE Project Healty Heath, vol FINAL Report Covering the project activities from 01/01/2010 to 31/12/2015, Provincie Drenthe, Assen

Pabbruwee K, de Groen B, Molen M (2018) Versterking Markermeerdijken - Projectplan Waterwet, vol AMMD-000339 (18.0214632), Hoogheemraadschap Hollands Noorderkwartier, Heerhugowaard

PBL (2010) Recreatiegebied om de stad. PBL. https://themasites.pbl.nl/balansvandeleefomgeving/jaargang-2010/landelijkgebied/recreatie/recreatiegebied-om-de-stad. Bezocht op 18-04-2019 2019

PBL (2017) Kwaliteit grondwaterafhankelijke ecosystemen. Planbureau voor de Leefomgeving. https://www.clo.nl/indicatoren/nl1594-kwaliteit-grondwaterafhankelijkeecosystemen?ond=20896. Bezocht op 30-10-2019 2019

Poot S, Oosterom T (2014) Kennisinventarisatie natuurlijke klimaatbuffer Voorne. Natuurmonumenten/Waterschap Hiollandse Delta. https://ruimtelijkeadaptatie.nl/voorbeelden/@160663/natuurlijke-f/. Bezocht op 24-10-2019 2019

Programma Rijke Waddenzee (2018) Projecten Eems Delta - Marconi Delfszijl. Eems Delta. http://www.ee-eemsdelta.nl/zoek-een-project/eemsdelta-projecten/duplicate-of-marconi. Bezocht op $16 / 12 / 20182018$

Projectbureau Ooijen-Wanssum, Aannemerscombinatie Mooder Maas (2019) Gebiedsontwikkeling Ooijen-Wanssum. https://www.ooijen-wanssum.nl/. Bezocht op 29/05/2019 2019

Projectbureau Zeeweringen (2012) Sophiastrand, Projectplan, PZDT-R-12294. Middelburg

Projectteam Rivierklimaatpark IJsselpoort (2019) Rivierklimaatpark IJsselpoort - Wonen, werken en recreëren aan een veilige IJssel. Provincie Gelderland. www.rivierklimaatpark.nl Bezocht op 03/11/2019 2019

Provincie Groningen, Ministerie van Infrastructuur en Milieu (2016) Programma Eems-Dollard 2050 Meerjarig adaptief programma voor ecologische verbetering in het gebied van de Eems en de Dollard. https://www.rijksoverheid.nl/documenten/rapporten/2016/07/05/programma-eemsdollard-2050. Bezocht op 05-05-2017 2017

Provincie Zuid-Holland (2017) PAS Gebiedsanalyse Voornes Duin, Den Haag

Reed DJ, van Wesenbeeck B, Herman PM, Meselhed E (2018) Tidal flat-wetland systems as flood defenses: Understanding biogeomorphic controls Estuarine, Coastal and Shelf Science 213:269-282

Remkes JW et al. (2019) Niet alles kan. Eerste advies van het adviescollege Stikstofproblematiek, Amersfoort 
Remmelzwaal AJ, Berger H, Kors A, Tanczos I, Helmer J (2019) Integrale Studie Waterveiligheid en peilbeheer (ISWP) - Aanbevelingen voor beleidskeuzes rond het toekomstig waterbeheer in het IJsselmeergebied, Rijkswaterstaat, Lelystad

Rijksoverheid (2018) Deltaprogramma 2019, maatregelen om Nederland tijdig aan te passen aan de klimaatverandering. Staf Delta Commissaris.

https://www.rijksoverheid.nl/actueel/nieuws/2018/09/18/deltaprogramma-2019-maatregelen-omnederland-tijdig-aan-te-passen-aan-de-klimaatverandering. Bezocht op 29/03/2019 2019

Rijkswaterstaat (2014a) Factsheet Kaderrichtlijn Water - Rijkswateren. Informatiehuis Water. https://www.waterkwaliteitsportaal.nl/Beheer/Rapportage/Publiek?viewName=Factsheets\&jaar=2 014\&maand=December. Bezocht op 02-07-2015 2015

Rijkswaterstaat (2014b) Vegetatielegger - een nieuw instrument dat bijdraagt aan een veilige doorstroming van de Nederlandse rivieren. https://www.rijkswaterstaat.nl/water/waterbeheer/bescherming-tegen-hetwater/waterkeringen/leggers/vegetatielegger/index.aspx. Bezocht op 20-04-2017 2017

Rijkswaterstaat (2015a) Beheer- en ontwikkelplan voor de rijkswateren 2016 - 2021, Den Haag

Rijkswaterstaat (2015b) Eén Afsluitdijk | vele verhalen. http://www.deafsluitdijk.nl/. Bezocht op 23-06-2015 2015

Rijkswaterstaat (2015c) Vismigratierivier. Ministerie van Infrastructuur en Milieu. http://www.deafsluitdijk.nl/projecten/vismigratierivier/. Bezocht op 02-06-2015 2015

Rijkswaterstaat (2018a) Factsheets Programma Grote Wateren. Rijkswaterstaat. https://www.helpdeskwater.nl/onderwerpen/water-ruimte/ecologie/programmagrote/@178960/factsheets-programma/. Bezocht op 28-06-2018 2018

Rijkswaterstaat (2018b) Programmatische Aanpak Ecologie Grote Wateren - Op weg naar dynamische en ecologisch gezonde grote wateren. Helpdesk Water.

https://www.helpdeskwater.nl/onderwerpen/water-ruimte/ecologie/programmatische/. Bezocht op 19/12/2018 2018

Rijkswaterstaat, Radboud Universiteit, Rijksuniversiteit Groningen (2019) Zeegrasherstel. https://zeegrasherstelwaddenzee.com/. Bezocht op 08/05/2019 2019

Roerink G (2018) NDVI - Najaarsupdate: Zomerdroogte en herstel op grasland. Wageningen Environmental Research. http://www.groenmonitor.nl/tags/ndvi. Bezocht op 05/06/2019 2019

Roode N, Maaskant B, Boon M (2019) Handreiking voorland. Hoogwaterbeschermingsprogramma. https://povvoorlanden.nl/. Bezocht op 29-05-2019 2019

Ruyssenaars PG et al. (2019) Greenhouse gas emissions in the Netherlands 1990-2017, RIVM National Institute for Public Health and Environment, Bilthoven, the Netherlands

Schepers M, Witkamp R, Berris L (2014) Monitoring natuurlijke klimaatbuffer Harger- en Pettemerpolder. Coalitie Natuurlijke Klimaatbuffers. https://ruimtelijkeadaptatie.nl/voorbeelden/@158306/natuurlijke-1/. Bezocht op 24-10-2019 2019

Schoevaart M, van Steeg W, Sturm S (2014) Audit Waterberging Onlanden, Bureau Balance

Schulp $\mathrm{N}$ et al. (2010) Variabiliteit in ruimte en tijd ontrafeld - Broeikasgasemissies uit Nederlandse landschappen Landschap 27:67-79

Schunselaar S, Dik P, de Greeff B (2014) Anserveld - Onderbouwing GGOR en WB21, Grontmij, Groningen

Smit M, Oosterhuis F, van Kreveld A, Braakhekke W (2014) De natuur als partner bij klimaatadaptatie - EEN PROCESEVALUATIE VAN TIEN KLIMAATBUFFERPROJECTEN, PBL, Bilthoven

Spoolder M (2013) Natuurontwikkeling Bonnerklap - Eindrapport: toelichting bij ontwikkelingsplan en definitief ontwerp Bonnerklap, Grontmij, Assen

Staf Deltacommissaris (2014) Deltaprogramma 2015 - Werk aan de Delta - de beslissingen om Nederland veilig te houden, Den Haag

Staf Deltacommissaris (2019) Deltaprogramma 2019 - Deltabeslissing Waterveiligheid. https://deltaprogramma2019.deltacommissaris.nl/3.html. Bezocht op 15/05/2019 2019

Sterk Consulting (2014) Besparingspotentieel 'Bouwen met natuur' Verkenning van het besparingspotentieel, Coalitie Natuurlijke Klimaatbuffers, Leiden

Stichting CAS, WEnR (2019) Hitte in Zeeland - Een story map. https://climadapserv.maps.arcgis.com/apps/MapJournal/index.html?appid=17a2d640a4944b5b95 ab488aa4851dc5. Bezocht op 06/05/2019 2019 
Tamis JE, Foekema EM (2015) A review of blue carbon in the Netherlands, IMARES rapport C151/15. Wageningen Marine Research, Den Helder

Tangelder M, De Groot AV, Ysebaert TJW (2014) Biobouwers als optimalisatie van waterveiligheid in de Zuidwestelijke Delta, Rapport C198/13. IMARES, Yerseke

Terpstra T, Tonkes M, Jacobs CMJ (2019) Hitte in kleine kernen ROMagazine september 2019

Teunis M, Didderen K (2018) Blue Carbon in Nederlandse kwelders - Resultaten van vier Kwelders in beheergebieden van Natuurmonumenten, Rapportnr. 18-301. Bureau Waardenburg - Ecologie \& Landschap

Tonnon PK, Mulder JPM (2013) Voorlandsuppleties; een verkenning van een kansrijke optie voor een sedimentstrategie in de Zuid-Westelijke delta, Deltaresrapport 1207694-002. Deltares, Delft

Uittenbroek CJ, Janssen-Jansen LB, Runhaar HAC (2013) Mainstreaming climate adaptation into urban planning: overcoming barriers, seizing opportunities and evaluating the results in two Dutch case studies Regional Environmental Change 13:399-411 doi:DOI 10.1007/s10113-012-0348-8

van Boekel WI, Blaauw R, de Bruin J, Oosterhuis R, Zoer B (2019) Broedvogels in De Onlanden in 2018, vol Rapport 2018/02, Stichting Natuurbelang De Onlanden, Groningen

Van de Koppel J, Gascoigne JC, Theraulaz G, Rietkerk M, Mooij WM, Herman PM (2008) Experimental evidence for spatial self-organization and its emergent effects in mussel bed ecosystems science 322:739-742

van de Koppel J, van der Heide T, Altieri AH, Eriksson BK, Bouma TJ, Olff H, Silliman BR (2015) LongDistance Interactions Regulate the Structure and Resilience of Coastal Ecosystems. In: Carlson CA, Giovannoni SJ (eds) Annual Review of Marine Science, Vol 7, vol 7. Annual Review of Marine Science. Annual Reviews, Palo Alto, pp 139-158. doi:10.1146/annurev-marine-010814-015805

van de Riet B, van den Elzen E, Hogeweg N, Smolders F, Lamers L (2017) Herstel van veenvormende natuur op landbouwgrond - Resultaten uit onderzoeksproject Omhoog met het Veen Bodem 2:32-34

Van den Akker J, Massop HTL, Rietstra RPJJ (2018) Potentiële emissiereductie broeikasgassen Fries veenweidegebied - Waterhuishoudkundige en bodembeheermaatregelen om broeikasgasemissies te beperken, vol WEnR rapport 2905, Wageningen Envrionmental Research, Wageningen

van den Akker JJH, Hendriks R (2014) Hogere grondwaterstanden voor veenweiden. Veenweiden: Aangepast watermanagement noodzakelijk voor beperking veenafbraak. Bodem 6:7-9

van den Born GJ, Bouwer LM, Goosen H, Hoekstra R, Huitema D, Schrijver R (2002) Klimaatwinst in Veenweidegebieden - Beheersopties voor het veenweidegebied integraal bekeken, ISBN: 90-5383 859 7. Instituut voor Milieuvraagstukken, Amsterdam

van den Born GJ, Kragt F, Henkens D, Rijken B, van Bemmel B, van der Sluis S (2016) DALENDE BODEMS,STIJGENDE KOSTEN - Mogelijke maatregelen tegen veenbodemdaling in het landelijk en stedelijk gebied, PBL-publicatienummer: 1064. Planbureau voor de Leefomgeving, Den Haag

van der Heide T, van Nes EH, Geerling GW, Smolders AJP, Bouma TJ, van Katwijk MM (2007) Positive feedbacks in seagrass ecosystems: Implications for success in conservation and restoration Ecosystems 10:1311-1322 doi:http://dx.doi.org/10.1007/s10021-007-9099-7

van der Heide T, van Nes EH, van Katwijk MM, Olff H, Smolders AJP (2011) Positive Feedbacks in Seagrass Ecosystems - Evidence from Large-Scale Empirical Data Plos One 6 doi:ARTN e16504 $10.1371 /$ journal.pone.0016504

van der Kaaij T, Huismans Y (2016) (Deltares 2016)Verkenning POA en Kier, Deltares, Delft

Van der Meulen MJ et al. (2007) Regional Sediment Deficits in the Dutch Lowlands: Implications for Long-Term Land-Use Options J Soils Sediments 7:9-16

van der Most H, Bouwer LM, Asselman N, Hoogendoorn R, Ellen GJ, Schasfoort F, Wagenaar D (2017) Meerlaagsveiligheid in de praktijk. STOWA.

https://www.stowa.nl/deltafacts/waterveiligheid/crisisbeheersing/meerlaagsveiligheid-de-praktijk. Bezocht op 22-10-2019 2019

van der Wel N (2017) Hondsbossche duinen...hoe gaat het met de natuur? https://duinenenmensen.nl/hondsbossche-duinenhoe-gaat-het-met-de-natuur/. Bezocht op 29-10-2019 2019

van der Zee EM et al. (2015) Habitat modification drives benthic trophic diversity in an intertidal softbottom ecosystem J Exp Mar Biol Ecol 465:41-48 doi:http://dx.doi.org/10.1016/j.jembe.2015.01.001

van der Zee F, de Knegt B, Meeuwsen H, Sanders M, Veraart JA, Grashof-Bokdam C, Wegman R (2016) Waterwinning en natuur - De betekenis van de drinkwatersector voor de natuur in Nederland, Alterra-rapport 2719. Wageningen 
van Deursen W, van Winden A, Braakhekke W (2013) Mogelijkheden voor bergen? Bergen van mogelijkheden!, Carthago Consultancy \& Bureau Stroming

Van Duren LA, van Katwijk MM (2015) Herstelmaatregel groot zeegras in de Nederlandse Waddenzee Haalbaarheid van de doelstellingen onder de kaderichtlijn Water, Deltares, Delft

van Egmond P et al. (2018) Balans van de leefomgeving 2018 - Nederland duurzaam vernieuwen, PBL-publicatienummer: 3160. Planbureau voor de Leefomgeving (PBL), Den Haag

Van Hattum T et al. (2014) Water en Natuur: Een mooi koppel! Onderzoek naar de succesfactoren, belemmeringen en kansen voor het meekoppelen van water- en natuuropgaven, Alterra-rapport 2533 / ISSN 1566-7197. Alterra Wageningen UR, Wageningen

van Hattum T, Timmerman J, van Buuren MW, de Lange MJ, Veraart JA, van Tol-Leenders D (2016) Kansenkaart Natuurambitie Grote Wateren - Inventarisatie van kansrijke uitvoeringsprojecten in de periode 2016-2021 die kunnen bijdragen aan de Natuurambitie Grote Wateren, ISSN 15667197. vol Alterra-rapport 2690, Alterra, Wageningen

van Hattum T, Veraart JA, de Lange MJ, van Buuren M, Krommendijk E (2015) Meekoppelkansen water- en natuuropgaven: Quickscan Hollands Noorderkwartier, Alterra-rapport. Alterra, Wageningen

Van Kreveld A (2013) A green Rhine Corridor - future proofing Western Europe's largest river for people, nature and the economy, Bureau Stroming, Nijmegen

van Kreveld A, Braakhekke W, Litjens G (2013) Natuurlijke klimaatbuffers mogelijkheden om geld te besparen door de inzet van natuur -een quickscan, Bureau Stroming

van Nieuwenhuizen C, Schouten CJ (2019) Brief regering - Programmatische Aanpak Grote Wateren: prioritering maatregelen. Ministerie van I\&W en LNV.

https://www.tweedekamer.nl/kamerstukken/amendementen/detail?id=2019Z14801\&did=2019D3 0331. Bezocht op 24-10-2019 2019

Van Popering-Verkerk J, Van Buuren A (2016) Dubbel-denken in de Delta, Erasmus Universiteit Rotterdam, Rotterdam

van Rijswijk M (2014) Handreiking landschappelijke inpassing en ruimtelijke kwaliteit in waterveiligheidsopgaven, vol Versie 1.0, Den Haag

Van Weesenbeeck BJ, Van de Koppel PMJ, Herman PMJ, Bakker T, Bouma J (2007) Biomechanical warfare in ecology; negative interactions between species by habitat modification. Oikos 116:742-750

Van Zanten E, Adriaanse L (2008) Verminderd getij. Verkenning naar mogelijke maatregelen om het verlies van platen, slikken en schorren in de Oosterschelde te beperken. Hoofdrapport Rijkswaterstaat, Rijkswaterstaat, Middelburg

Veenendaal M, Fens J (2012) Feugelpôlle: klussen aan een polder Vakblad Natuur Bos Landschap Oktober 2012:48-49

Vellinga NE, Hoitink AJF, van der Vegt M, Zhang W, Hoekstra P (2014) Human impacts on tides overwhelm the effect of sea level rise on extreme water levels in the Rhine-Meuse delta Coastal Engineering 90:40-50 doi:https://doi.org/10.1016/j.coastaleng.2014.04.005

Vellinga TV, Reijs JW, Lesschen JP, van Kernebeek HR (2018) Lange termijn opties voor reductie van broeikasgassen uit de Nederlandse landbouw- Een verkenning, RAPPORT 1133. Wageningen Livestock Research, Lelystad

Veraart, J.A., Backx J, Schotman A (2019) Voorverkenning Ecologische Kansen en Risico's van Maatregelen uit Programmatische aanpak Grote Wateren - Aanvulling op de RHDHV QuickScan, RWS-WVL \& WUR, Lelystad

Veraart JA, Klostermann JEM (2019) Verkenning van kennisbehoeften binnen LIFE IP Deltanatuur ten bate van stroomlijning binnen kennisagenda's, Wageningen Environmental Research, Wageningen

Veraart JA, van Duinen R, Vreke J (2017) Evaluation of Socio-Economic Factors that Determine Adoption of Climate Compatible Freshwater Supply Measures at Farm Level: a Case Study in the Southwest Netherlands Water Resour Manag 31:587-608 doi:10.1007/s11269-016-1399-2

Veraart JA, Vos CC, Spijkerman A, Witte JPM (2014) Meekoppelkansen tussen Natura 2000, Kaderrichtlijn Water en het Deltaprogramma in de Klimaatcorridor Veenweide - een quick scan klimaatadaptatie, Wageningen

Veraart JA, Werners SE, Tangelder M, Groot AME, de Bel M, Mulder JPM (2016) Vooroeversuppleties in de Oosterschelde - Meerwaarde voor ecologie, economie en waterveiligheid Landschap 3:142-151

Verdegaal W et al. (2018) DNB Sustainable Finance Platform's Working Group on Climate Risk Reflections on integrating TCFD-style information into risk/return decisionmaking from the Dutch financial sector, De Nederlandse Bank (DNB), Den Haag 
Verdonschot R, Verdonschot P (2019) Monitoring effecten zandsuppletie Leuvenumse beek 2018, Zoetwaterecosystemen, Wageningen Environmental Research, Wageningen

Vermaat JE, Aerts MAPA (2012) The effect of the spatial arrangement of wetlands on water quality improvement and carbon sequestration, Synthesis Report, KvR report number 049/12

Vertegaal P, Borren W, Schouten BC (2019) Natte natuur in het klimaatakkoord - win win in het kwadraat Vakblad Natuur Bos Landschap Februari:12-15

Vliegenthart A, van der Zee F (2018) Delfstofwinning en Natuur, ISSN 1566-7197. vol Rapport 2873, Wageningen Environmental Research / Vlinderstichting, Wageningen

VNSC (2012) De Vlaams-Nederlandse Schelde Commissie. http://www.vnsc.eu/. Bezocht op 26-07 2012

Vuik V, Jonkman B, Willemsen PWJM, Borsje BW, Janssen SKH, Hermans LM, Bouma TJ (2019) Voorlanden voor Hoogwaterbescherming H2O Magazine - Water Matterd September 2019:7-9

Walles B, Ysebaert T, van den Brink A, Boersema M (2018) Ecologisch herstel op de Veiligheidsbuffer Oesterdam Waterhuishouding \& Waterbouw 1:24-25

Wang Z, Edwin E, van der Spek A, Quirijn L (2018) Sediment budget and morphological development of the Dutch Wadden Sea - Impact of accelerated sea-level rise and subsidence until 2100 Netherlands Journal of Geosciences -Geologie en Mijnbouw 97:183-214 doi:10.1017/njg.2018.8

Waternet (2019) Amsterdam Rainproof -als elke druppel telt. Waternet. https://www.rainproof.nl/. Bezocht op 06/05/2019 2019

Waterschap noorderzijlvest (2019) Optimalisatie waterberging De Onlanden. https://www.noorderzijlvest.nl/ons-werk/projecten/projecten-(lopend)/optimalisatie-onland/. Bezocht op 03/11/2019 2019

Waterschap Vechtstromen (2014) Project klimaatbestendig Dinkeldal RTV-Oost. https://www.rtvoost.nl/nieuws/203446/2-3-miljoen-euro-voor-Dinkeldal-om-water-op-te-vangenbij-extreem-weer Bezocht op 2019

Waterschap Vechtstromen (2017) Project klimaatbestendig Nieuw Drostendiep https://www.vechtstromen.nl/buurt/projecten/drostendiep/updates/nieuwdrostendiep/waterschap/. 2019

Waterschap Vechtstromen (2019) LUMBRICUS - Onderzoeksprogramma voor een klimaatrobuust bodem- en watersysteem. https://www.programmalumbricus.nl/. Bezocht op 2-4-2019 2019

Weijters $\mathrm{M}$ et al. (2015) Praktijkproef heideontwikkeling op voormalige landbouwgrond in het Noordenveld - Resultaten 2011-2014, Nationaal Park Dwingelderveld

Wiersma A, Van Hattum T, de Lange MJ, van Slobbe EJJ (2018) Building with Nature pilot Friese IJsselmeerkust - Eindrapportage Building with Nature pilot Zandmotor Friese IJsselmeerkust, Deltaresrapport 1230636-000. Utrecht

Wijnja H (2019) Bijna 100\% zeegras bij Griend. Natuurmonumenten. https://www.natuurmonumenten.nl/natuurgebieden/griend/nieuws/bijna-100-zeegras-bij-griend. Bezocht op 25-10-2019 2019

Wösten $\mathrm{H}$, Brouwer $\mathrm{F}$, Kruijt B, Jacobbs CMJ, Veraart JA (in voorbereiding) Kansen en handelingsperspectieven om broeikasgassen in natuurterreinen vast te leggen, Wageningen Environmental Research, Wageningen

Zuidhof A, Lankester J, Pedroli B, Maas G, van Heusden W, Snels G (2017) Natuurverkenning Rivieren. Veerkrachtig ecosysteem voor de grote rivieren, RVO/Wageningen Environmental Research, Wageningen 
Wageningen Environmental Research Postbus 47

6700 AA Wageningen

T 0317480700

www.wur.nl/environmental-research

Wageningen Environmental Research Rapport 2975

ISSN 1566-7197
De missie van Wageningen University \& Research is 'To explore the potential of nature to improve the quality of life'. Binnen Wageningen University \& Research bundelen Wageningen University en gespecialiseerde onderzoeksinstituten van Stichting Wageningen Research hun krachten om bij te dragen aan de oplossing van belangrijke vragen in het domein van gezonde voeding en leefomgeving. Met ongeveer 30 vestigingen, 5.000 medewerkers en 10.000 studenten behoort Wageningen University \& Research wereldwijd tot de aansprekende kennisinstellingen binnen haar domein. De integrale benadering van de vraagstukken en de samenwerking tussen verschillende disciplines vormen het hart van de unieke Wageningen aanpak. 



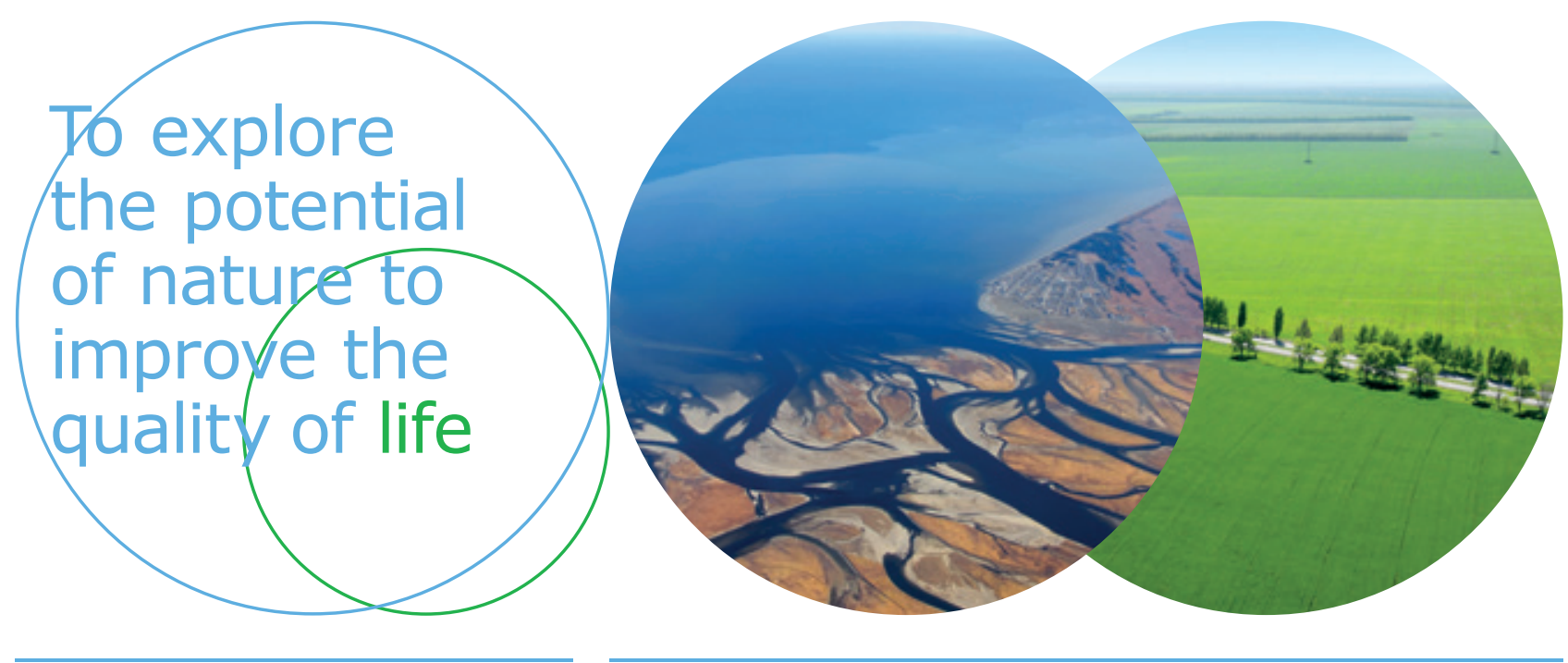

Wageningen Environmental Research Postbus 47

$6700 \mathrm{AB}$ Wageningen

T 317480700

www.wur.nl/environmental-research

Rapport 2975

ISSN 1566-7197
De missie van Wageningen University \& Research is 'To explore the potential of nature to improve the quality of life'. Binnen Wageningen University \& Research bundelen Wageningen University en gespecialiseerde onderzoeksinstituten van Stichting Wageningen Research hun krachten om bij te dragen aan de oplossing van belangrijke vragen in het domein van gezonde voeding en leefomgeving. Met ongeveer 30 vestigingen, 5.000 medewerkers en 10.000 studenten behoort Wageningen University \& Research wereldwijd tot de aansprekende kennisinstellingen binnen haar domein. De integrale benadering van de vraagstukken en de samenwerking tussen verschillende disciplines vormen het hart van de unieke Wageningen aanpak. 